Portland State University

PDXScholar

10-6-1995

\title{
Geochemistry of the Boring Lava along the West Side of the Tualatin Mountains and of Sediments from Drill Holes in the Portland and Tualatin Basins, Portland, Oregon
}

Michelle Lynn Barnes

Portland State University

Follow this and additional works at: https://pdxscholar.library.pdx.edu/open_access_etds

Part of the Geology Commons

Let us know how access to this document benefits you.

\section{Recommended Citation}

Barnes, Michelle Lynn, "Geochemistry of the Boring Lava along the West Side of the Tualatin Mountains and of Sediments from Drill Holes in the Portland and Tualatin Basins, Portland, Oregon" (1995). Dissertations and Theses. Paper 4990.

https://doi.org/10.15760/etd.6866

This Thesis is brought to you for free and open access. It has been accepted for inclusion in Dissertations and Theses by an authorized administrator of PDXScholar. Please contact us if we can make this document more accessible: pdxscholar@pdx.edu. 
THESIS APPROVAL

The abstract and thesis of Michelle Lynn Barnes for the Master of Science in Geology were presented October 6 , 1995, and accepted by the thesis committee and the department.

COMMITTEE APPROVALS :
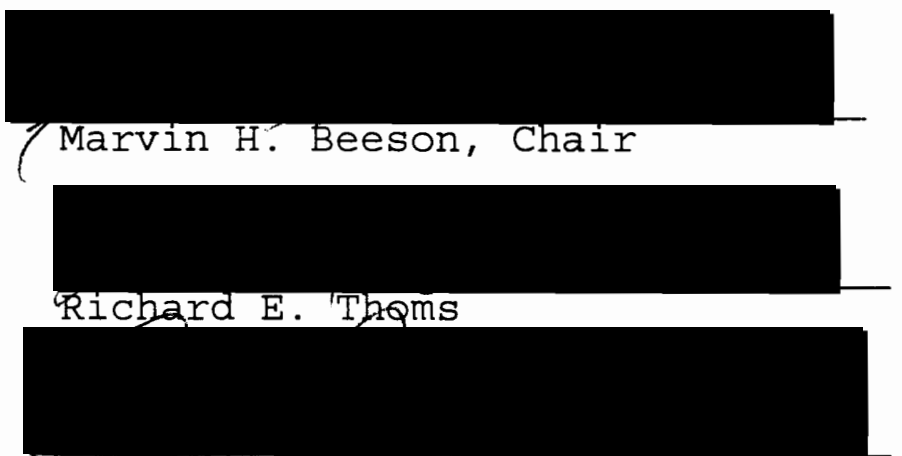

Ansel//G. Johnson

DEPARTMENT APPROVAL :

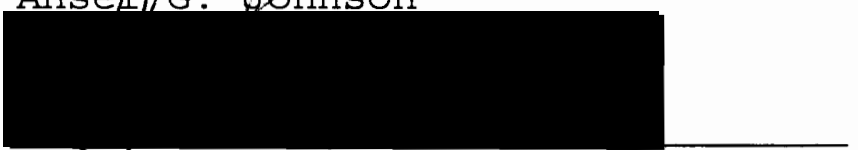

Trevor D. Smith

Representative of the office of Graduate studies

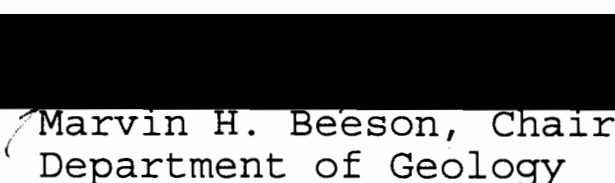

Department of Geology

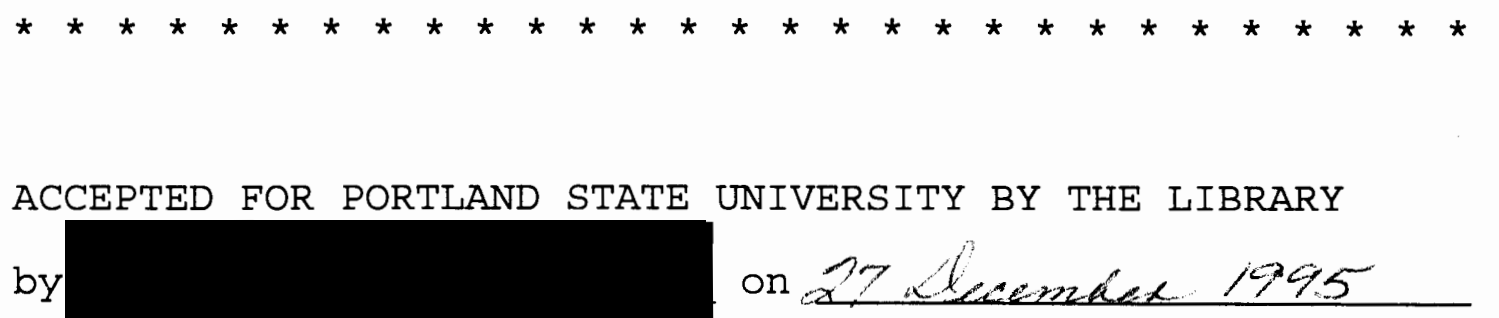


ABSTRACT

An abstract of the thesis of Michelle Lynn Barnes for the Master of Science in Geology presented October 6, 1995.

Title: Geochemistry of the Boring Lava along the West Side of the Tualatin Mountains and of Sediments from Drill Holes in the Portland and Tualatin Basins, Portland, Oregon.

Instrumental Neutron Activation Analysis (INAA) was used to identify geochemical groups in Boring Lava along the west side of the Tualatin Mountains, and in sediments of the Portland and Tualatin basins. Samples of Boring Lava were obtained from Trimet drill core collected during planning of the tunnel alignment for the Westside Light Rail line. Additional samples of Boring Lava were collected from outcrops along the west side of the Tualatin Mountains. Samples of sediment from the Tualatin and Portland basins were obtained from drill core collected during an Oregon Department of Geology and Mineral Industries (DOGAMI) Earthquake Hazards Mapping project. 
INAA of Boring Lava samples resulted in the identification of three geochemical groups. Additional data sets, including $\mathrm{x}$-ray fluorescence geochemistry, magnetic polarity, and age dates, allowed for the distinction of three Boring Lava units. The Boring Lava of Barnes Road is a young, normal unit, the Boring Lava of Sylvan Hill is an older normal unit, and the Boring Lava of Cornell Mountain is the oldest, reversed unit. The surface distribution, identified using topography and outcrop geochemistry, is consistent with the subsurface distribution, identified using boring logs and core geochemistry. Volcanic vent locations are proposed at topographic highs within the identified surface distribution of the Boring Lava of Barnes Road. INAA of sediment samples resulted in the identification of seven groups: (1) Columbia River source sediments, (2) lower Troutdale Formation, (3) Reed Island ashes, (4) young Columbia River sediments, (5) highalumina basalt sediments, (6) episodic Cascadian volcanic sediments, and (7) Columbia River Basalt Group (CRBG) sediments. Only the CRBG sediments group was identified in the Tualatin basin, while all seven groups were identified in the Portland basin. This appears to demonstrate that the sediment packages in the two basins are different. 
Finally, each sediment group can be placed into one of three broad geochemical categories: Columbia River source sediments and lower Troutdale Formation represent a Columbia River or continental source; Reed Island ashes, young Columbia River sediments, high-alumina basalt sediments, and episodic Cascadian volcanic sediments represent a Cascadian or local source; and CRBG sediments represent residual soils or sediments overlying Columbia River basalt flows. 


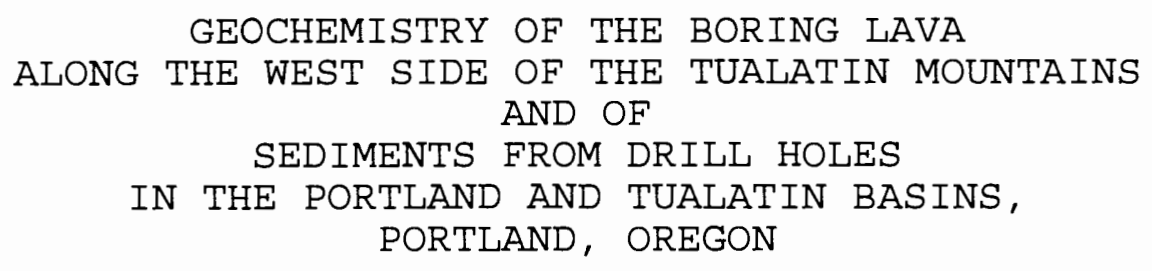

by

MICHELLE LYNN BARNES

A thesis submitted in partial fulfillment of the requirements for the degree of
MASTER OF SCIENCE
in
GEOLOGY
Portland State University
1995




\section{ACKNOWLEDGEMENTS}

First, I'd like to thank my parents. As I was growing up, they were forever reminding me that I could choose to be whatever I wanted, and that I could accomplish anything. They have supported, wholeheartedly, my endeavors as a geologist since high school.

Second, I'd like to thank everyone who took part in this project: Dr. Marv Beeson, my advisor; Brian Peterson and Steve Hay, excellent rock crushers; Dody Orendurff and Sheryl Zinsle, eager-to-learn undergraduate students; Guy Weisenbach, the CAD-guy; and Sara Havnar, word processing genius. I'd also like to thank Trimet, the Oregon Department of Transportation, and the Oregon Department of Geology and Mineral Industries (DOGAMI) for supplying core and chip samples for analysis, and DOGAMI for supporting my research during the summer of 1993. In addition, a big THANKS goes to the Reed College Nuclear Reactor staff for their prompt attention to my requests.

Finally, I'd like to give an extra special thank you to my husband-to-be, Brian Peterson. He has been unbelievably helpful and patient during the final "hours" of this project. 
TABLE OF CONTENTS

PAGE

LIST OF TABLES $\ldots \ldots \ldots \ldots \ldots \ldots \ldots \ldots \ldots \ldots \ldots \ldots \ldots \ldots \ldots \ldots$

LIST OF FIGURES $\ldots \ldots \ldots \ldots \ldots \ldots \ldots \ldots \ldots \ldots \ldots \ldots \ldots \ldots \ldots \ldots$

INTRODUCTION $\ldots \ldots \ldots \ldots \ldots \ldots \ldots \ldots \ldots \ldots \ldots \ldots \ldots \ldots \ldots \ldots$

PREVIOUS WORK $\ldots \ldots \ldots \ldots \ldots \ldots \ldots \ldots \ldots \ldots \ldots \ldots \ldots \ldots \ldots \ldots$

LOCAL GEOGRAPHY $\ldots \ldots \ldots \ldots \ldots \ldots \ldots \ldots \ldots \ldots \ldots \ldots \ldots \ldots \ldots \ldots$

Tualatin Mountains $\ldots \ldots \ldots \ldots \ldots \ldots \ldots \ldots \ldots \ldots \ldots$

Portland and Tualatin Basins ............ 9

LOCAL STRATIGRAPHY $\ldots \ldots \ldots \ldots \ldots \ldots \ldots \ldots \ldots \ldots \ldots \ldots \ldots \ldots$

METHOD OF INVESTIGATION $\ldots \ldots \ldots \ldots \ldots \ldots \ldots \ldots \ldots$

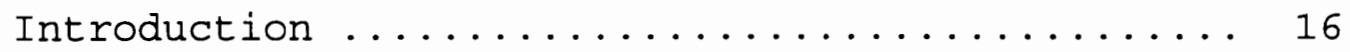

Choice of Method .................. 16

General Theory of Activation Analysis ........ 17

Sample Location $\ldots \ldots \ldots \ldots \ldots \ldots \ldots \ldots \ldots \ldots \ldots$

Sample Description ................ 27

Irradiation 93D
Irradiation 93E
Irradiation 93G
Irradiation 94A

Sample Preparation ................. 29

Analysis Procedure .................. 30

DATA AND RESULTS $\ldots \ldots \ldots \ldots \ldots \ldots \ldots \ldots \ldots \ldots \ldots \ldots \ldots \ldots \ldots$ 
BORING LAVA INTERPRETATION ............... 37

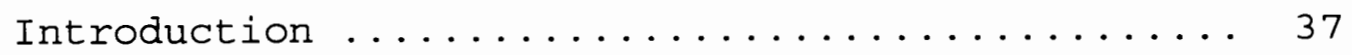

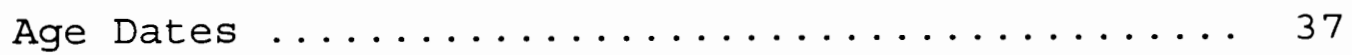

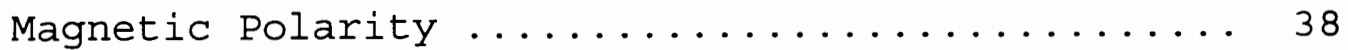

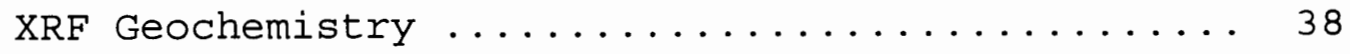

INAA Geochemistry ................... 39

Statistical Analysis ................. 50

Discussion ............................. 51

SEDIMENT GEOCHEMISTRY AND INTERPRETATION ......... 55

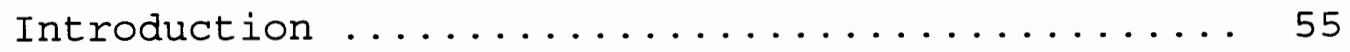

Shallow sediment and Miscellaneous Samples..... 55

High-Alumina Basalt sediments

CRBG Sediments

Reed Island Ashes

Young Columbia River Sediments

Columbia River Source Sediments

Portland International Airport Drill Hole ......

Young Columbia River Sediments

Episodic Cascadian Volcanic Sediments

Lower Troutdale Formation

Hillsboro Airport Drill Hole ............. 85

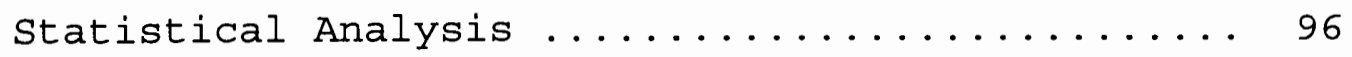

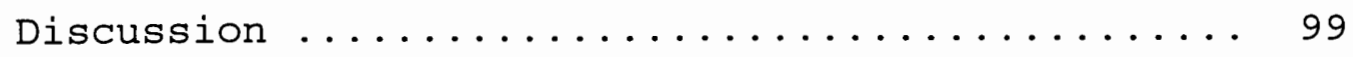

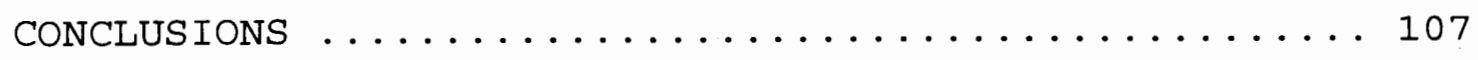

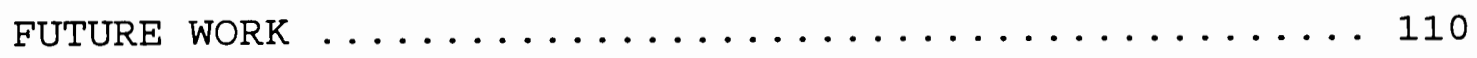

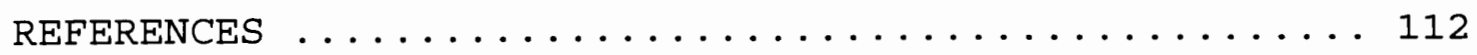


APPENDICES

A Geochemical Data for the Boring Lava ...... 116

B Geochemical Data for the shallow sediment and Miscellaneous Samples ............. 127

C Geochemical Data for the Hillsboro

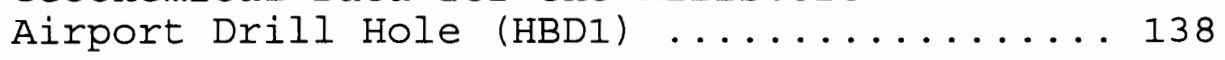

D Geochemical Data for the Portland International Airport Drill Hole (MTDI) .... 145

E Geochemical Data for Standards Used in Irradiations 93D, 93E, 93G, and 94A ...... 151

F Statistical Analysis Tables ............ 154 


\section{LIST OF TABLES}

I Comparison of five key stratigraphic

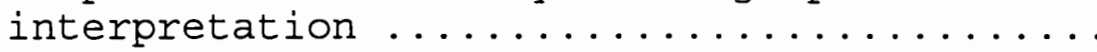

I Age dates and sample numbers for the

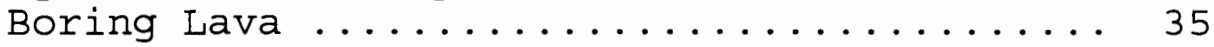

II Magnetic polarity and sample numbers

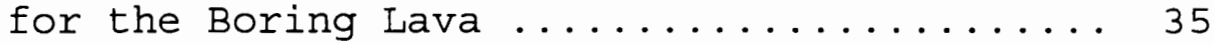

IV X-ray fluorescence data for selected Boring

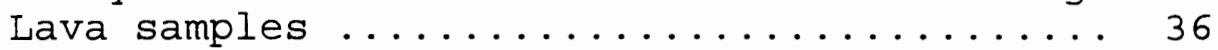

$\mathrm{V}$ Approximate ages of the five samples that

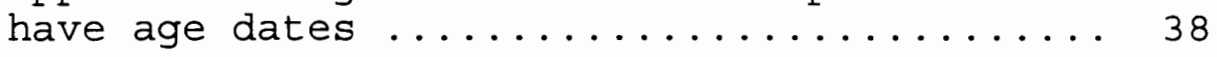

VI Magnetic polarity and selected INAA data for the four samples along the tunnel alignment which have age dates ................. 45

VII Comparison of the depth of occurrence of volcanic or hyaloclastite materials in wells examined by Hoffstetter (1984) and

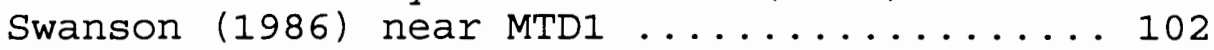




\section{LIST OF FIGURES}

FIGURE

PAGE

1 Geography of the Portland, Oregon area .... 7

2 Approximate location of the tunnel

alignment through the Tualatin Mountains ... 8

3 Trimet drill core sample locations ....... 20

4 Locations of DOGAMI drill holes sampled

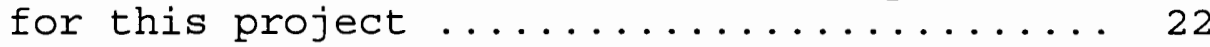

5 Location of outcrop samples and two chip/core samples collected along the west side of the Tualatin Mountains ...... 23

6 Approximate location of Boring Lava samples collected by Dr. Marvin H. Beeson ......... 24

7 Approximate location of the

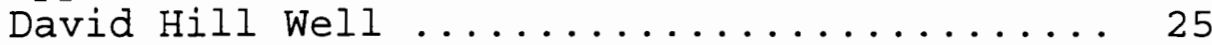

8 Approximate location of the samples collected from Reed Island ............ 26

9 Boring Lava Scatter Plot Scandium vs. Cerium ................. 40

10 Boring Lava Scatter Plot Iron vs. Chromium .................. 41

11 Boring Lava Scatter Plot Lanthanum vs. Scandium .............. 42

12 Surface distribution of Boring Lava (road $\operatorname{map}) \ldots \ldots \ldots \ldots . \ldots \ldots 4 . \ldots \ldots$

13 Surface distribution of Boring Lava (topographic map) ................ 47

14 Distribution of Boring Lava along the west end of line section 5A of the Trimet tunnel alignment ................ 48 
15 Shallow Sediments scatter plot Iron vs. Hafnium ................. 57

16 Shallow Sediments Scatter Plot Hafnium vs. Thorium ............... 58

17 Shallow Sediments Scatter Plot Closeup Hafnium vs. Thorium ............... 59

18 Shallow Sediments Scatter Plot Cobalt vs. Hafnium ............... 60

19 Shallow Sediments Scatter Plot Lanthanum/Samarium vs. Iron ........... 61

20 Shallow Sediments Scatter Plot Lanthanum/Samarium vs. Hafnium

21 Shallow Sediments Chondrite Plot High-Alumina Basalt Sediments .......... 65

22 Shallow Sediments Chondrite Plot Samples from Trimet drill hole B563 ...... 67

23 Shallow Sediments Chondrite Plot Samples from Trimet drill hole B565 ...... 68

24 Shallow Sediments Chondrite Plot Reed Island Ashes and BVD4-91.4 Sample .... 70

25 Shallow Sediments Chondrite Plot Young Columbia River Sediments ......... 72

26 Shallow Sediments Chondrite Plot Columbia River Source Sediments ......... 75

27 Shallow Sediments Chondrite Plot Columbia River Source Sediments ......... 76

28 Portland International Airport Drill Hole Sediments Scatter Plot Hafnium vs. Chromium ............... 79

29 Portland International Airport Drill Hole Sediments Scatter Plot

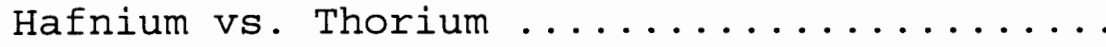


30 Portland International Airport Drill Hole Sediments Chondrite Plot Episodic Cascadian Volcanic Sediments ..... 82

31 Portland International Airport Drill Hole Sediments Chondrite Plot Lower Troutdale Formation ............. 83

32 Portland International Airport Drill Hole Sediments Chondrite Plot Lower Troutdale Formation ............... 84

33 Shallow and Portland International Airport Drill Hole Sediments Scatter Plot

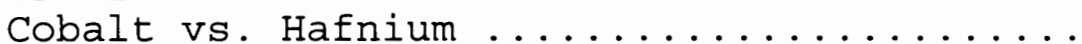

34 Shallow and Portland International Airport Drill Hole Sediments Scatter Plot

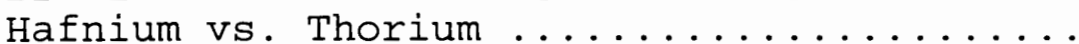

35 Shallow and Portland International Airport Drill Hole Sediments scatter Plot Lanthanum/Samarium vs. Hafnium ..........

36 Hillsboro Airport Drill Hole Sediments Scatter Plot Lanthanum/Samarium vs. Iron ............ 90

37 Hillsboro Airport Drill Hole Sediments Scatter Plot

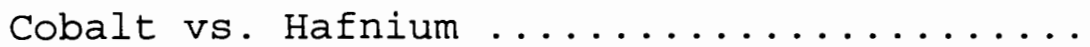

38 Hillsboro Airport Drill Hole Sediments Chondrite Plot CRBG Sediments and the ash layer@760'....

39 Shallow, Portland, and Hillsboro Drill Hole Sediments scatter Plot

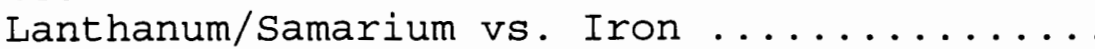

40 Shallow, Portland, and Hillsboro Drill Hole Sediments Scatter Plot

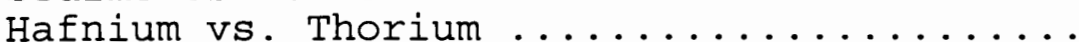

41 Shallow, Portland, and Hillsboro Drill Hole Sediments Scatter Plot

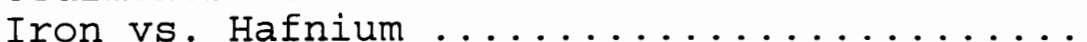




\section{INTRODUCTION}

The Quaternary and late Tertiary geologic history of the Portland, Oregon area is rich with complexity. It involves many processes, including (1) eruption of a local volcanic unit, the Boring Lava, (2) the deposition and erosion of sedimentary units including the Troutdale Formation, Sandy River Mudstone, Portland Hills silt (glacial loess), and catastrophic flood sediments, and (3) structural deformation resulting from regional stress regimes (Beeson and others, 1989; Yeats and others, 1991), the locally identified Portland Hills structural zone (Balsillie and Benson, 1971; Beeson and others, 1989), and related, local, parallel structural zones (Yelin and Patton, 1991; Madin and others, 1993).

This mix of constructive and destructive geologic processes has produced a complex stratigraphy to study. Though much work has been completed by many geologists on a range of scales (i.e. Treasher, 1942; Trimble, 1963; Hart and Newcomb, 1965; Schlicker and Deacon, 1967; Allen, 1975; Beeson and others, 1989; Madin, 1990; Squier Associates, 1992; Blakely and others, 1995), there still remain many unanswered questions concerning (1) the origin of the Boring Lava, (2) the effect of the presence/absence 
of the incipient Tualatin Mountains on deposition of the Columbia River Basalt Group (CRBG) and sediments, (3) the distribution of catastrophic flood materials, and (4) the stratigraphy of the Portland and Tualatin basins.

This study focuses on the geochemistry of post-CRBG volcanic and sedimentary rocks, specifically the Boring Lava, Sandy River Mudstone, Troutdale Formation, Portland Hills Silt, and Missoula Floods deposits. Geochemical analyses of the Troutdale Formation and Sandy River Mudstone in the Portland basin (Swanson, 1986) have been completed as part of a previous study by a Portland state University graduate student. Aside from this thesis, however, few geochemical data exist for the above mentioned units. Geochemical data, when used in combination with other data sets (magnetic polarity, $\mathrm{x}$-ray fluorescence, field/core/hand samples, and age dates) allow realistic hypotheses to be suggested for problems relating to stratigraphy, structure, age, and provenance.

The information presented in this study is two-fold. The first portion of the study addresses the geochemistry of the Boring Lava along the west side of the Tualatin Mountains. The second portion addresses the geochemistry of Portland and Tualatin basin sediments, as represented in drill holes located in the two basins and along the tunnel alignment in the Tualatin Mountains. Although the 
same method was used to obtain data for both parts of the study, each is discussed separately. Conclusions for both sections are presented at the end of the study. 


\section{PREVIOUS WORK}

The first detailed mapping of the Portland, Oregon area was done by Treasher (1942). He is credited with naming the Boring Lava for its occurrence near the town of Boring, Oregon. Following Treasher, Trimble (1963) published a detailed map and geologic report that is still used as a reference today. In it he defines a detailed stratigraphic column for the Tualatin Mountains and the Portland basin.

During the next 30 years, reports were published on the stratigraphy, groundwater, and engineering geology of both the Tualatin and Portland basins (i.e. Schlicker and others, 1964; Hart and Newcomb, 1965; Hogenson and Foxworthy, 1965; Schlicker and Deacon, 1967; Frank and Collins, 1978; Yeats and others, 1991). Typically, geologists examined either one basin or the other in their reports, not both.

In the 1970's, geologists began to recognize important structural features, particularly the Portland Hills-Clackamas River structural zone and its association with the Tualatin Mountains (Balsillie and Benson, 1971; Allen, 1975; Beeson and others, 1975). In the 1980's, the stratigraphy of the CRBG was presented by Hooper (1982), 
and a series of papers was published examining that stratigraphy and its relationship to the evolution of the Portland basin, the location of ancestral Columbia River channels, and the deposition of the Sandy River Mudstone and the Troutdale Formation (Tolan and Beeson, 1984; Beeson and others, 1985; Beeson and others, 1989).

In 1990, Madin revisited Trimble's (1963) map area to assess potential earthquake hazard areas. Small revisions were made in the geology in some locations and the stratigraphic column was simplified. Some of the most recently published work includes a geologic map of the Portland Quadrangle by Beeson and others (1991), the Westside Light Rail Tunnel Project Technical Report completed by Squier Associates (1992), and an aeromagnetic survey map by Blakely and others (1995). 


\section{LOCAL GEOGRAPHY}

\section{TUALATIN MOUNTAINS}

The Tualatin Mountains, commonly known as the Portland Hills or the West Hills, are aligned with the Portland Hills-Clackamas River fault zone, a northwesttrending structure identified by Beeson and others (1989) as the western boundary of a pull-apart basin. Tolan and Reidel (1989) and Yelin and Patton (1991) identify an eastern boundary to this pull apart basin; Tolan and Reidel (1989) called it the Lacamas Lake-Sandy River fault zone while Yelin and Patton (1991) called it the Frontal Fault zone. As Tolan and Reidel (1989) first identified it, the name they chose will be used herein. Portland is located within this pull-apart basin (Figure 1).

The Tualatin Mountains were a critical area of study for the current project of extending the light rail system to the west side of the Portland area. The new light rail line has been designed to pass through the Tualatin Mountains via a tunnel (Figure 2). Large amounts of drill core and new geologic information were produced during the studies conducted to choose a tunnel alignment. 


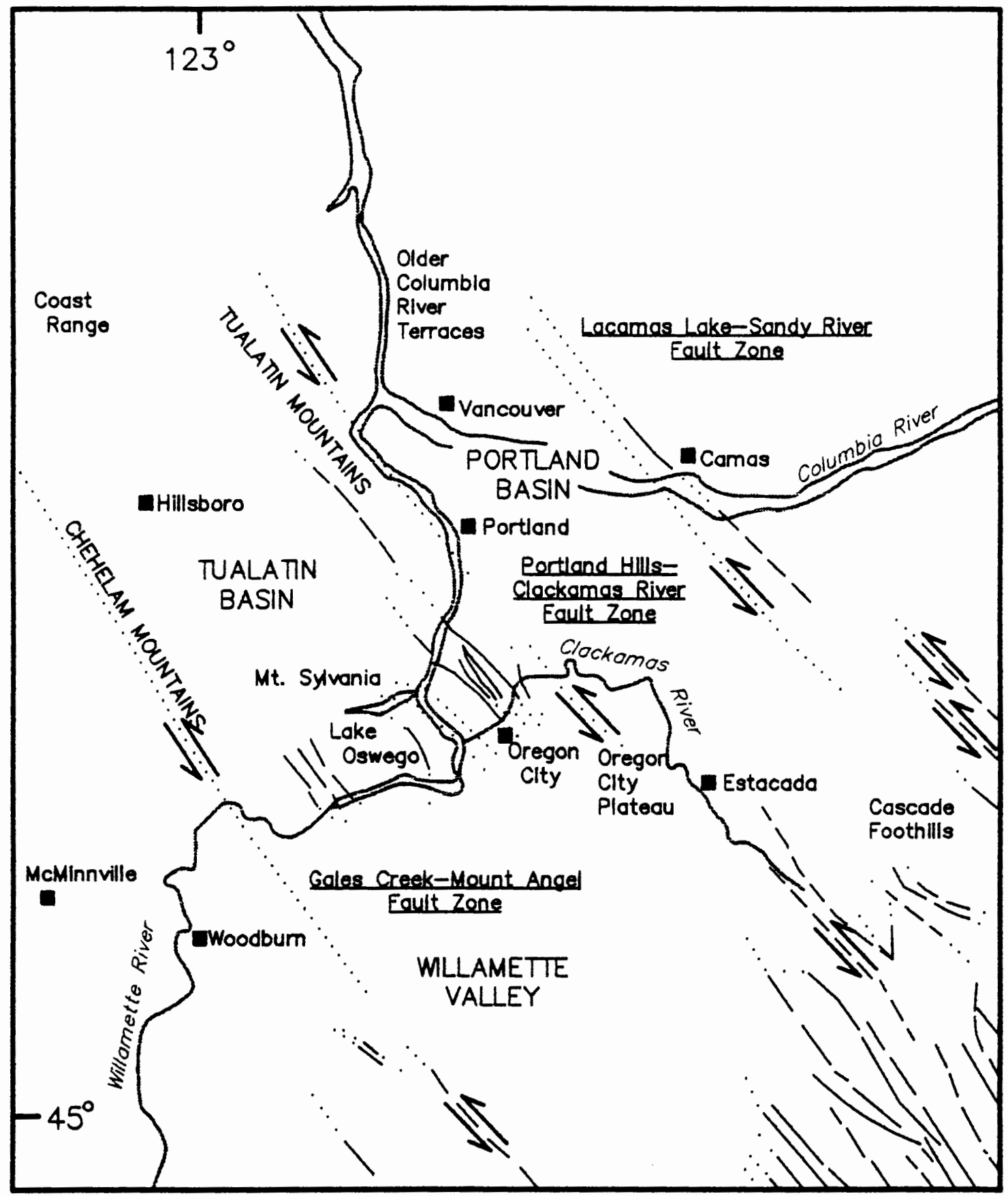

Fiqure 1. Geography of the Portland, Oregon area. Modified from Tolan and Reidel (1989). 


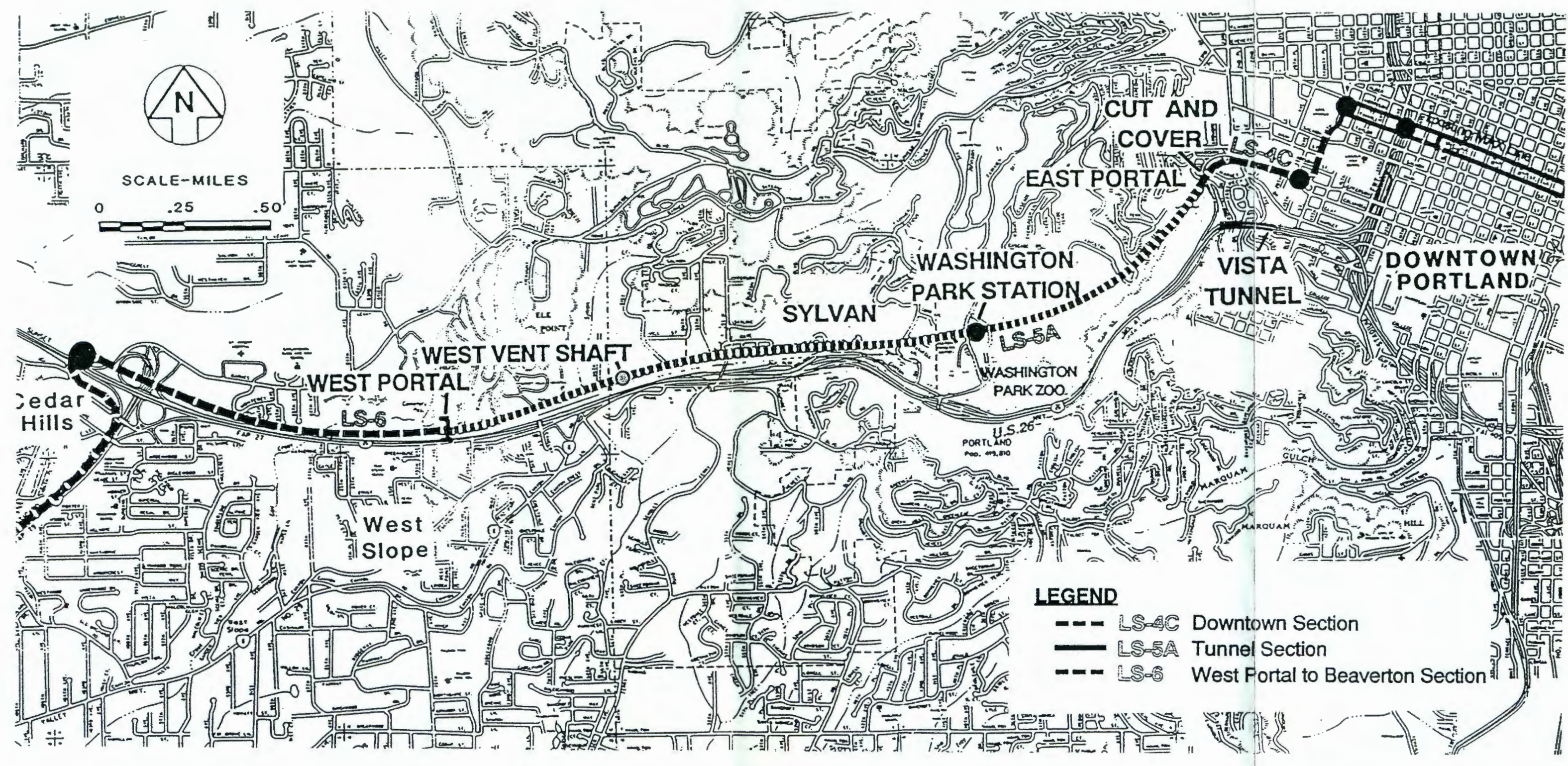

Fiqure 2. Approximate location of the tunnel alignment through the Tualatin

Mountains. The west portion of Line section 5A, from Sylvan to the West Portal, was examined for this study. 
PORTLAND AND TUALATIN BASINS

The Tualatin Mountains separate the Portland pull apart basin, or the Portland basin, on the east, from the Tualatin basin on the west (Figure 1). The Portland basin is that area between the Tualatin Mountains and Portland Hills-Clackamas River fault zone on the west, the Oregon City plateau on the south, the foothills of the Cascades on the south and southeast, the Lacamas Lake-Sandy River fault zone on the east and northeast, and old Columbia River terraces on the north. The Tualatin basin is that area between the Chehalem Mountains on the west, Mt. Sylvania and Lake Oswego on the south, the Tualatin Mountains on the east and northeast, and the coast Range on the north and northwest.

Each basin contains a thick sequence of sediments overlying the CRBG. Prior to the development of the Portland Hills, the two basins may have received similar depositional materials. The rise of the Portland Hills likely altered the distribution of materials into each basin, which should have resulted in unique stratigraphic sequences for each basin.

The Oregon Department of Geology and Mineral Industries (DOGAMI) has undertaken a study in the Portland area, to identify geographic areas overlying sediments that could potentially liquefy during an earthquake. To 
accomplish this, DOGAMI has completed numerous drill holes in both the Portland and Tualatin basins, to identify and log the sediments. The study will result in the publication of new earthquake hazard maps for the Portland area. Maps for the Portland, Lake Oswego, Gladstone, and Beaverton 7.5 minute Quadrangles are currently available. 


\section{LOCAL STRATIGRAPHY}

The primary focus of this study is the geochemistry of post-CRBG units in the Portland area. As such, the interpretations presented in this study will be primarily based on the geochemical data. However, previous interpretations of the stratigraphy have not used geochemistry as a basis for describing stratigraphic units. Consequently, several interpretations, proposed by previous authors, must be considered. The following is a review of five key interpretations as presented by Hart and Newcomb (1965), Schlicker and Deacon (1967), Trimble (1963), Madin (1990), Tolan and Beeson (1993).

Table I shows a comparison of five interpretations of Portland area stratigraphy. The two left-hand columns are interpretations of Tualatin basin stratigraphy and the three right-hand columns are interpretations of Portland basin stratigraphy.

Each of the previous authors have recorded similar interpretations of the stratigraphy. In fact, from the CRBG through the Boring Lava, the only differences among the five columns are the presence of the Sandy River Mudstone and the Rhododendron Formation in the Portland basin stratigraphic columns (Trimble, 1963; Tolan and 
Table I. A comparison of five stratigraphic
interpretations (from left to right: Hart \& Newcomb,
1965; Schlicker \& Deacon, 1967; Trimble, 1963; Madin,
1990; Tolan \& Beeson, 1993). Columns modified after above
authors; not to scale.

\begin{tabular}{|c|c|c|c|c|c|c|c|}
\hline \multicolumn{2}{|c|}{ AGE } & \multicolumn{2}{|c|}{ TUALATIN BASIN } & \multicolumn{4}{|c|}{ POATLAND BASIN } \\
\hline \multirow{9}{*}{$\begin{array}{l}\mathbf{Q} \\
\mathbf{U} \\
\mathbf{A} \\
\mathbf{T} \\
\mathbf{E} \\
\mathbf{R} \\
\mathbf{N} \\
\mathbf{A} \\
\mathbf{R} \\
\mathbf{Y}\end{array}$} & $\mathbf{H}$ & Alluvium & Alluvium & $\begin{array}{l}\text { Alluvium } \\
\text { Bog Denosits }\end{array}$ & \multirow{2}{*}{\multicolumn{2}{|c|}{$\begin{array}{l}\text { Artificial } \\
\text { Fill }\end{array}$}} & \multirow{3}{*}{$\begin{array}{l}\text { Alluvium } \\
\text { Colluvium }\end{array}$} \\
\hline & $\mathbf{L}$ & \multirow{8}{*}{$\begin{array}{c}\text { Tertiary \& } \\
\text { Quaternary } \\
\text { Valley } \\
\text { Fill }\end{array}$} & \multirow{2}{*}{$\begin{array}{c}\text { Gales Creek } \\
\text { Terrace } \\
\text { Gravels }\end{array}$} & Landslides & & & \\
\hline & 0 & & & Terraces & \multicolumn{2}{|l|}{ Alluviu } & \\
\hline & $\mathbf{P}$ & & \multirow{3}{*}{$\begin{array}{l}\text { Lacustrine } \\
\text { Deposits }\end{array}$} & $\begin{array}{l}\text { sand \& silt } \\
\text { Lacustrine }\end{array}$ & \multicolumn{2}{|c|}{$\begin{array}{c}\text { Flood } \\
\text { Deposits }\end{array}$} & Flood Deposits \\
\hline & $\mathrm{L}$ & & & Estacada & \multirow{2}{*}{\multicolumn{2}{|c|}{$\begin{array}{l}\text { Clackamas } \\
\text { liverTerraces }\end{array}$}} & \multirow{4}{*}{$\begin{array}{c}\text { fluvial } \\
\text { deposits \& } \\
\text { debris flows }\end{array}$} \\
\hline & E & & & Gre & & & \\
\hline & $\frac{2}{I}$ & & \multirow{2}{*}{$\begin{array}{l}\text { Willamette } \\
\text { Silt }\end{array}$} & Lot & \multicolumn{2}{|c|}{ Loess } & \\
\hline & \begin{tabular}{|l}
3 \\
$T$
\end{tabular} & & & Springwater & \multicolumn{2}{|c|}{$\begin{array}{l}\text { Boring } \\
\text { Lava }\end{array}$} & \\
\hline & 0 & & Upland Silt & Waltēers Hill & \multirow{2}{*}{$\begin{array}{c}\text { STrout- } \\
\text { dale } \\
\mathrm{Fm} . \\
\end{array}$} & \multirow{2}{*}{ SRM } & Loess \\
\hline \multirow{5}{*}{$\mathrm{T}$} & & $\begin{array}{l}\text { Boing } \\
\text { Lava }\end{array}$ & $\begin{array}{l}\text { Boring } \\
\text { Lava }\end{array}$ & $\begin{array}{l}\text { Boring } \\
\text { Lava }\end{array}$ & & & \\
\hline & \multirow{2}{*}{$\begin{array}{l}\text { P } \\
\mathbf{L} \\
\mathbf{I} \\
\mathbf{O}\end{array}$} & \multirow{2}{*}{$\begin{array}{l}\text { Troutdale } \\
\text { Formation }\end{array}$} & \multirow{2}{*}{$\begin{array}{l}\text { Troutdale } \\
\text { Formation }\end{array}$} & $\begin{array}{l}\text { Troutdale } \\
\text { Formation }\end{array}$ & \multirow{2}{*}{$\begin{array}{l}\text { Sandy } \\
\text { River } \\
\text { Mud- } \\
\text { Stone } \\
\text { (SRM) }\end{array}$} & Equiv & \\
\hline & & & & $\begin{array}{l}\text { Sandy River } \\
\text { Mudstone }\end{array}$ & & & $\begin{array}{l}\text { Troutdale } \\
\text { Formation }\end{array}$ \\
\hline & \multirow{2}{*}{$\begin{array}{l}\mathrm{M} \\
\mathrm{I} \\
\mathrm{O}\end{array}$} & \multirow{2}{*}{ CRBG } & \multirow[t]{2}{*}{ CRBG } & $\begin{array}{l}\text { Rhododendron } \\
\text { Fm. (RFM) }\end{array}$ & \multirow{2}{*}{\multicolumn{2}{|c|}{ CRBG }} & $\mathrm{SRM} / \mathrm{RFM}$ \\
\hline & & & & CRBG & & & CRBG \\
\hline
\end{tabular}


Beeson, 1993) and the addition of the Helvetia Formation in the Tualatin basin stratigraphic column (Schlicker and Deacon, 1967). Madin (1990) identifies a sedimentary unit in the Tualatin basin (SRM equivalent) that he interprets to include the Troutdale Formation, the equivalent to the Sandy River Mudstone of the Portland basin, and the Helvetia Formation of Schlicker and Deacon (1967). Madin (1990) and Tolan and Beeson (1993) identify Troutdale Formation deposits interfingered with Boring Lava.

By far the largest discrepancies occur in the columns during Pleistocene times. Much of this has to do with the interpretation of field evidence that likely represents the remains of catastrophic flood sediments, periodically released from Lake Missoula in western Montana during the last Ice Age. In the Tualatin basin, the Tertiary and Quaternary Valley Fill of Hart and Newcomb (1965), and the Willamette silt, lacustrine deposits, and terrace gravels of Gales Creek of Schlicker and Deacon (1967) are most probably deposits of the Missoula Floods. In the Portland basin, Trimble (1963) presented a detailed interpretation for the Pleistocene epoch. Madin (1990) examined the Quaternary stratigraphy for both basins and suggested the following simplifications: 
Catastrophic flood deposits

Includes the terrace, sand and silt, and lacustrine deposits of Trimble (1963), and the lacustrine deposits and willamette silt of Schlicker and Deacon (1967).

Clackamas River terraces

Includes the Estacada Formation of Trimble (1963).

Loess

Includes the upland silt of Schlicker and Deacon (1965).

Troutdale Formation

Includes the Gresham and Walters Hill Formation of Trimble (1963).

Madin (1990) also added artificial fill as a stratigraphic unit due to the nature of his study.

The final interpretation listed (Tolan and Beeson, 1993) generally agrees with that suggested by Madin (1990). The unit identified as fluvial deposits and debris flows by Tolan and Beeson (1993) likely represents materials similar to the Clackamas River terraces of Madin (1990), and would include materials deposited by the Clackamas River, or volcanic materials that flowed down the Clackamas River channel.

The interpretations presented by Madin (1990), and Tolan and Beeson (1993), represent some of the most updated information regarding Portland area stratigraphy. A new interpretation will not be presented as a part of 
A new interpretation will not be presented as a part of this study. The units to be defined during this study will be placed into the existing stratigraphic framework. As such, the description of the units mapped in the Portland and Tualatin basins will not change, and are not presented here. For descriptions of each unit, please refer to the appropriate reference as listed in the above table. 


\section{METHOD OF INVESTIGATION}

\section{INTRODUCTION}

The primary method of investigation used for this study was Instrumental Neutron Activation Analysis (INAA). Magnetic polarity of basalt samples was also measured using a fluxgate magnetometer. Additional data sets were available for the Boring Lava samples and include geochemical analyses by $x$-ray fluorescence (XRF) and age dates obtained using $\mathrm{K}-\mathrm{Ar}$ dating methods.

\section{CHOICE OF METHOD}

Unpublished INAA and XRF data (Beeson, 1993; personal communication) indicated that trace elements could be useful in differentiating Boring Lava units. Sediments made up of differing source materials should have differing trace element concentrations as well (Piper, 1974; McLennan and Taylor, 1980; Bhatia and Taylor, 1981; Kadri and others, 1983). Thus, INAA was chosen as the primary method of investigation because of its ability to detect a wide range of trace elements, and its availability at Portland State University. 
GENERAL THEORY OF ACTIVATION ANALYSIS

Activation analysis is based on the principle that radioactive isotopes of different elements have distinct radioactive decay patterns. Bombarding a sample with neutrons in a nuclear reactor produces unstable isotopes or radioisotopes. As the radioisotopes decay, they emit gamma rays (electromagnetic radiation) of specific energies. These gamma rays can be observed by a high purity Germanium detector. When a gamma ray of a specific energy is observed by the detector, one "count" for the gamma ray of that energy, is recorded by an analyzing unit connected to the detector. Based on the energy of each observed gamma ray, the analyzing unit stores gamma ray "counts" into data files. Each time a gamma ray of a specific energy is detected and recorded, the number of counts for that gamma ray increases by one in that data file. For each sample analyzed, a range of gamma ray energies, in the form of a spectrum of gamma ray energy peaks, is produced by the elements present in that sample. Several standards having known elemental concentrations determined by a variety of independent analytical techniques, are also included in the data set. Comparison of the sample spectra to the standard spectra, allow the elemental concentrations for each sample to be calculated (Muecke, 1980). 


\section{SAMPLE LOCATION}

A total of 163 samples were analyzed for this study from two main sources:

1. Drill core taken by Trimet for studies conducted to locate a suitable tunnel alignment through the Tualatin Mountains for extension of the light rail line to the Tualatin Valley. The drill hole numbers and depth at which each sample was collected is shown on Figure 3.

2. Drill core taken by DOGAMI in the Portland and Tualatin basins for their Relative Earthquake Hazards Mapping Project. Approximately 20 shallow drill holes (50-300 feet) are located throughout the two basins. One deep drill hole is located near the center of each basin: HBDI at the Hillsboro Airport in the Tualatin basin (1095 feet), and MTDI at the Portland International Airport in the portland basin (1523 feet). Figure 4 shows the approximate locations of the sampled drill holes. 
Nineteen samples were obtained from sources other than the two mentioned above. Additional sources include:

3. Ten outcrop samples of the Boring Lava located along the west side of the Tualatin Mountains as shown on Figure 5. Two core/chip samples were also obtained from the same area and are also shown on Figure 5.

4. Three outcrop samples of Boring Lava, collected previously by Dr. Marvin Beeson, from Mt. Sylvania and Cookes Butte as shown on Figure 6 .

5. One sample obtained from a commercial bag of bentonite drilling mud.

6. One sample of pre-CRBG sediment collected by Doyle Wilson, from the David Hill well at the western edge of the Tualatin basin. The well is believed to be located in Section 22, Township 1 North, Range 4 West of the Willamette Meridian on the Gales Creek Quadrangle (Figure 7).

7. Two volcanic ash samples collected from Reed Island in the Columbia River east of the Sandy River Delta. Both samples were collected from the south side of the island, in section 22, Township 1 North, Range 4 East of the Willamette Meridian on the Washougal Quadrangle (Figure 8). 


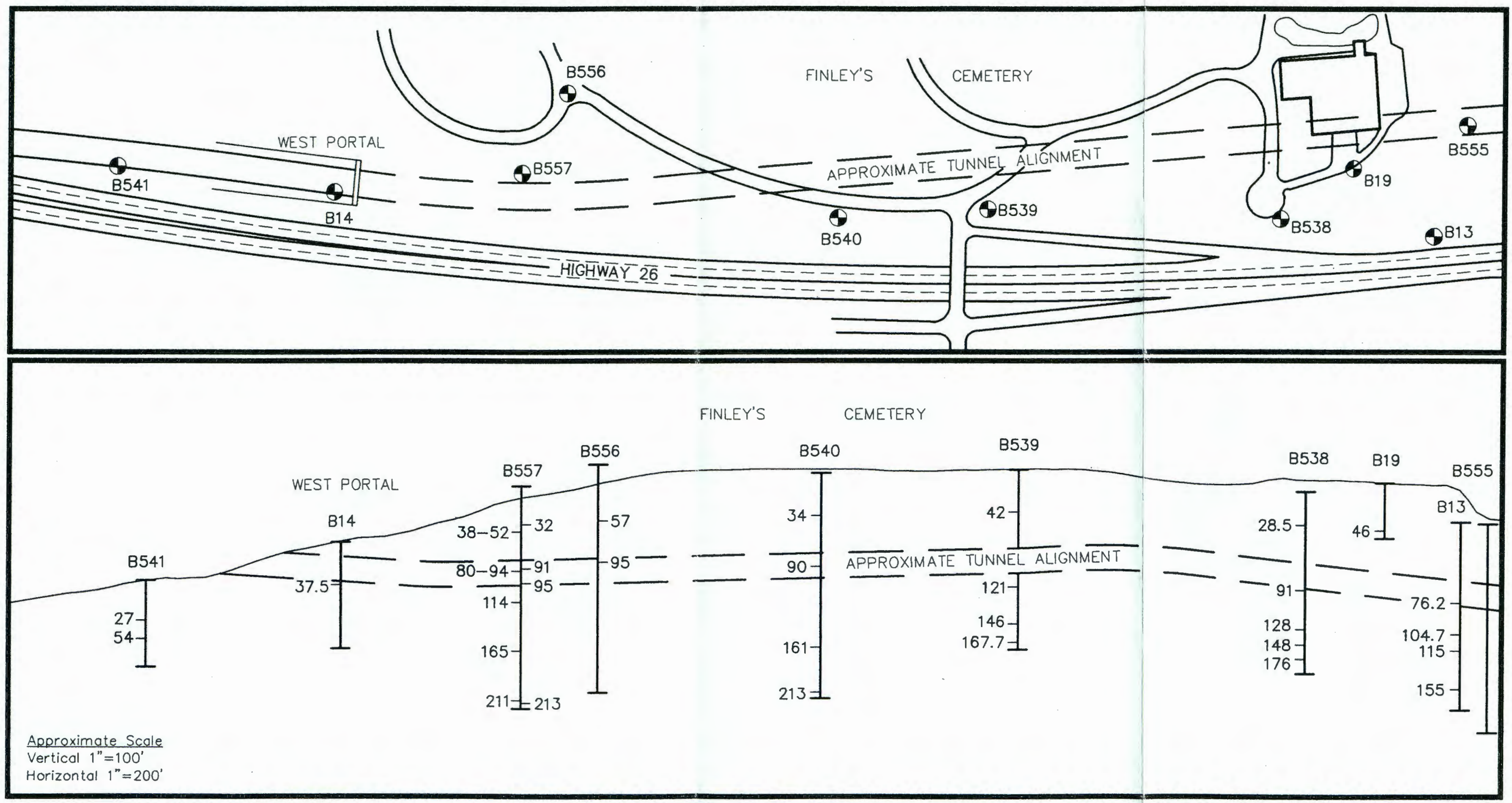

Figure 3. Trimet drill core sample locations. Modified after Squier Associates (1992). 

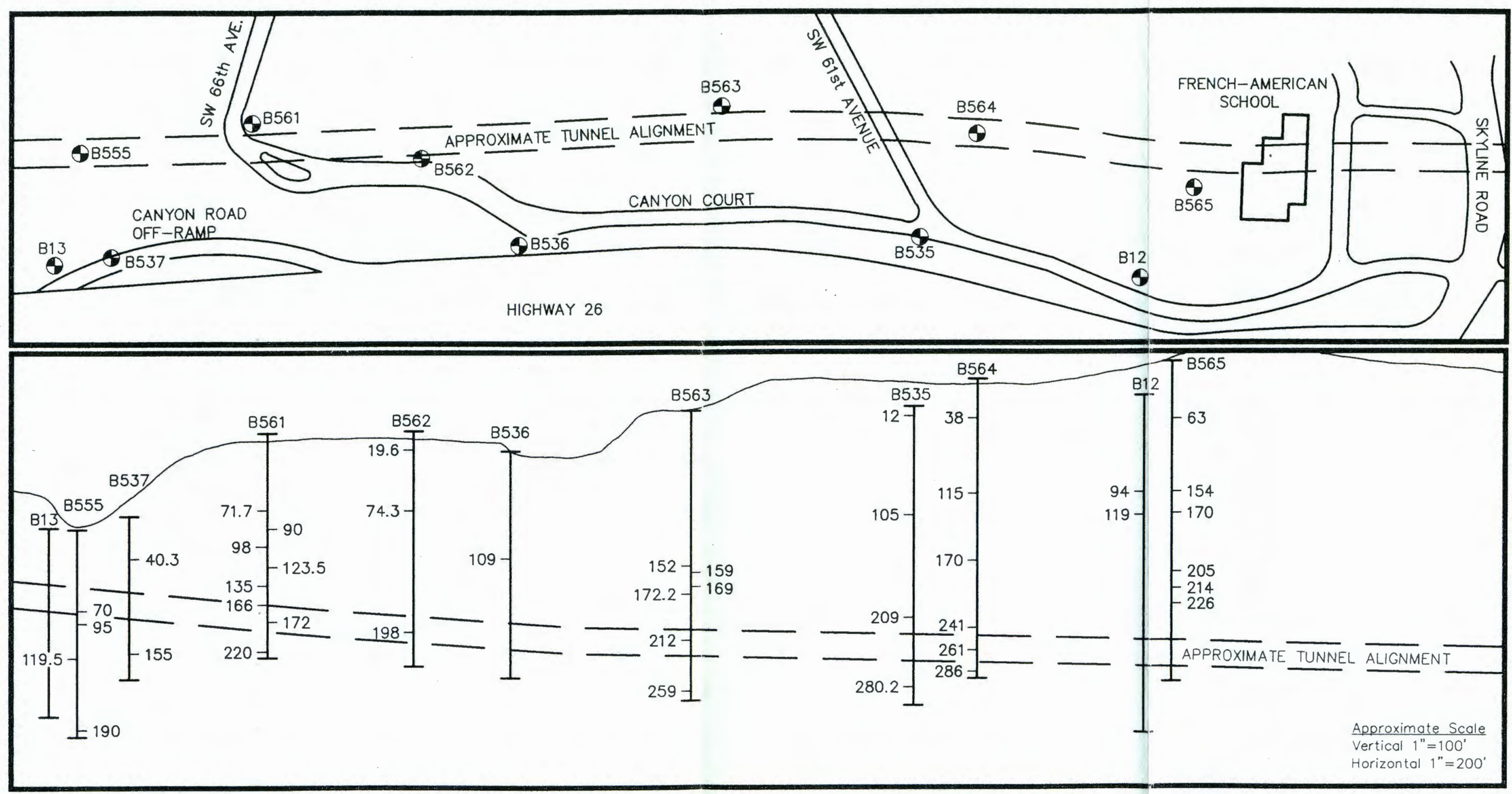


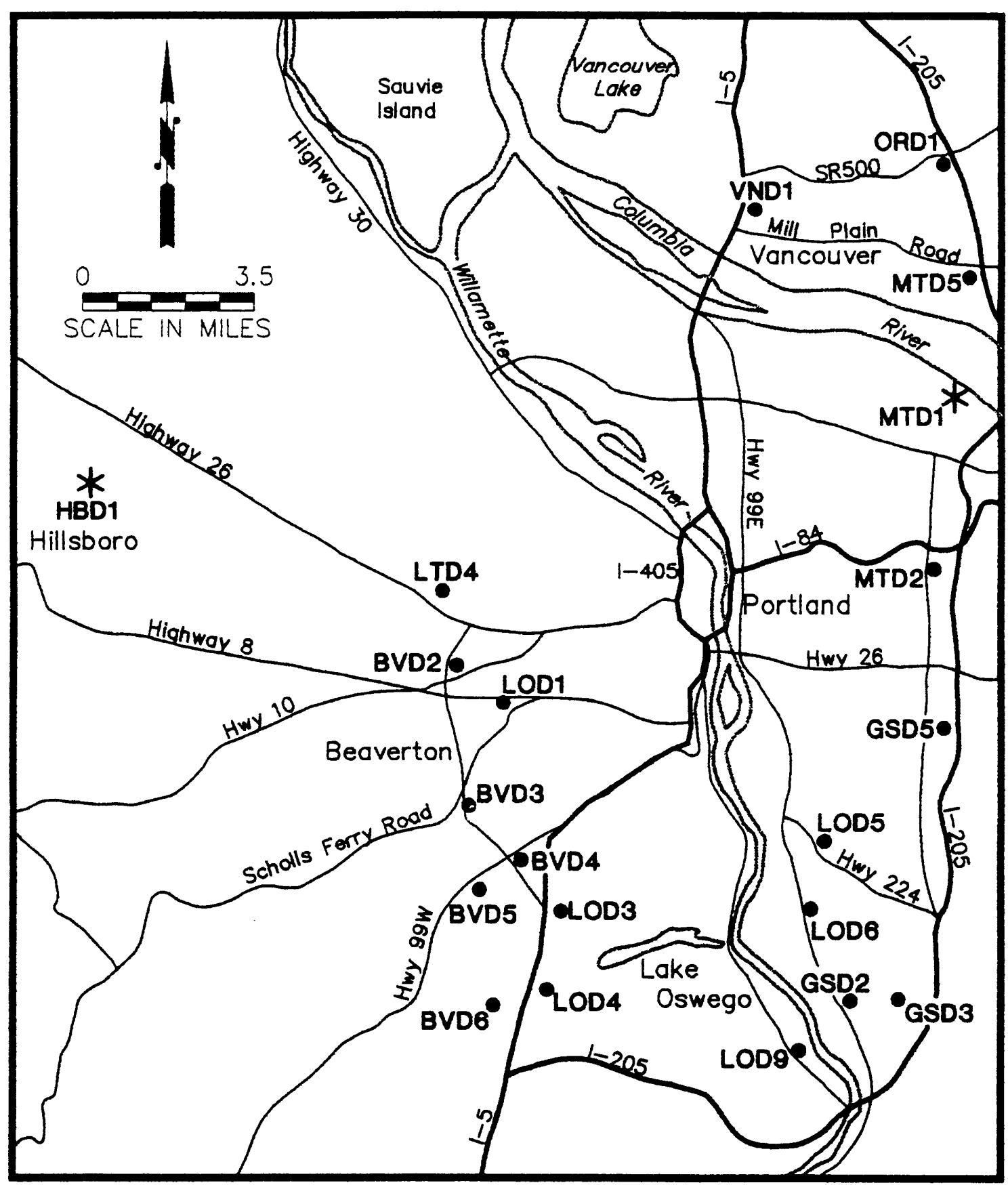

Figure 4. Locations of DOGAMI drill holes sampled for this project. Stars represent the two deep drill hole locations. 


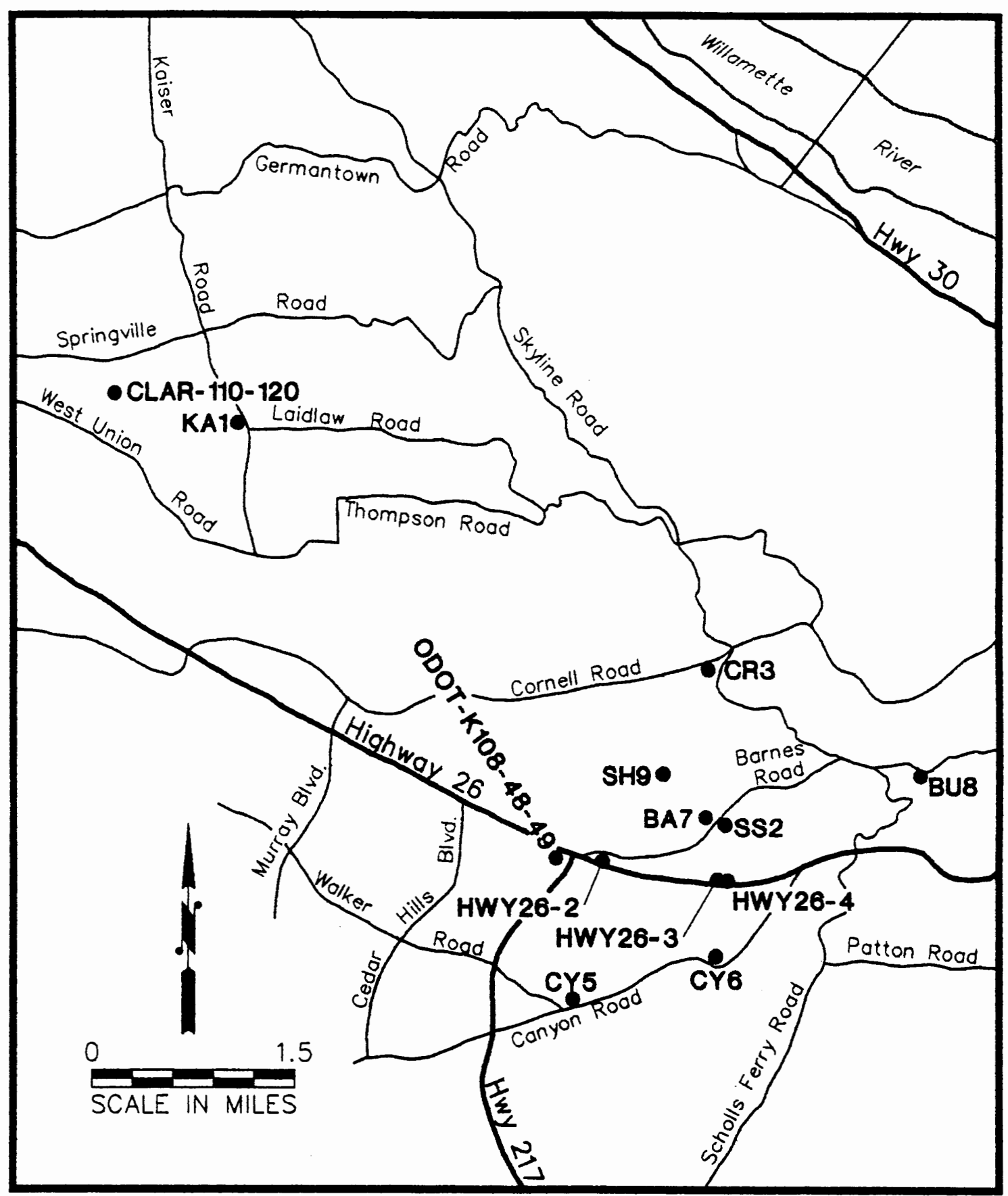

Figure 5. Location of outcrop samples and the two chip/core samples collected along the west side of the Tualatin Mountains. 


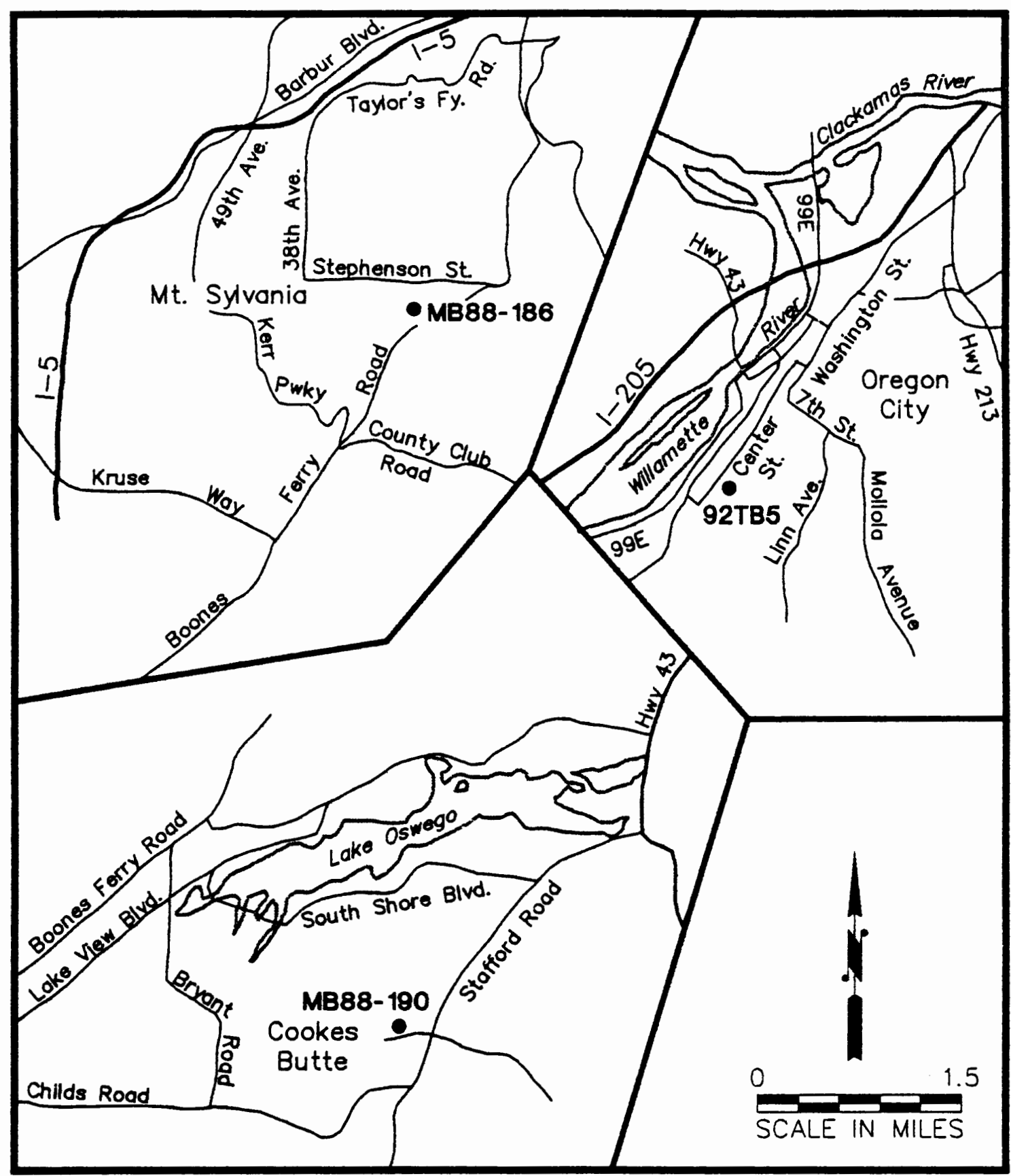

Figure 6. Approximate location of Boring Lava samples collected by Dr. Marvin Beeson. 


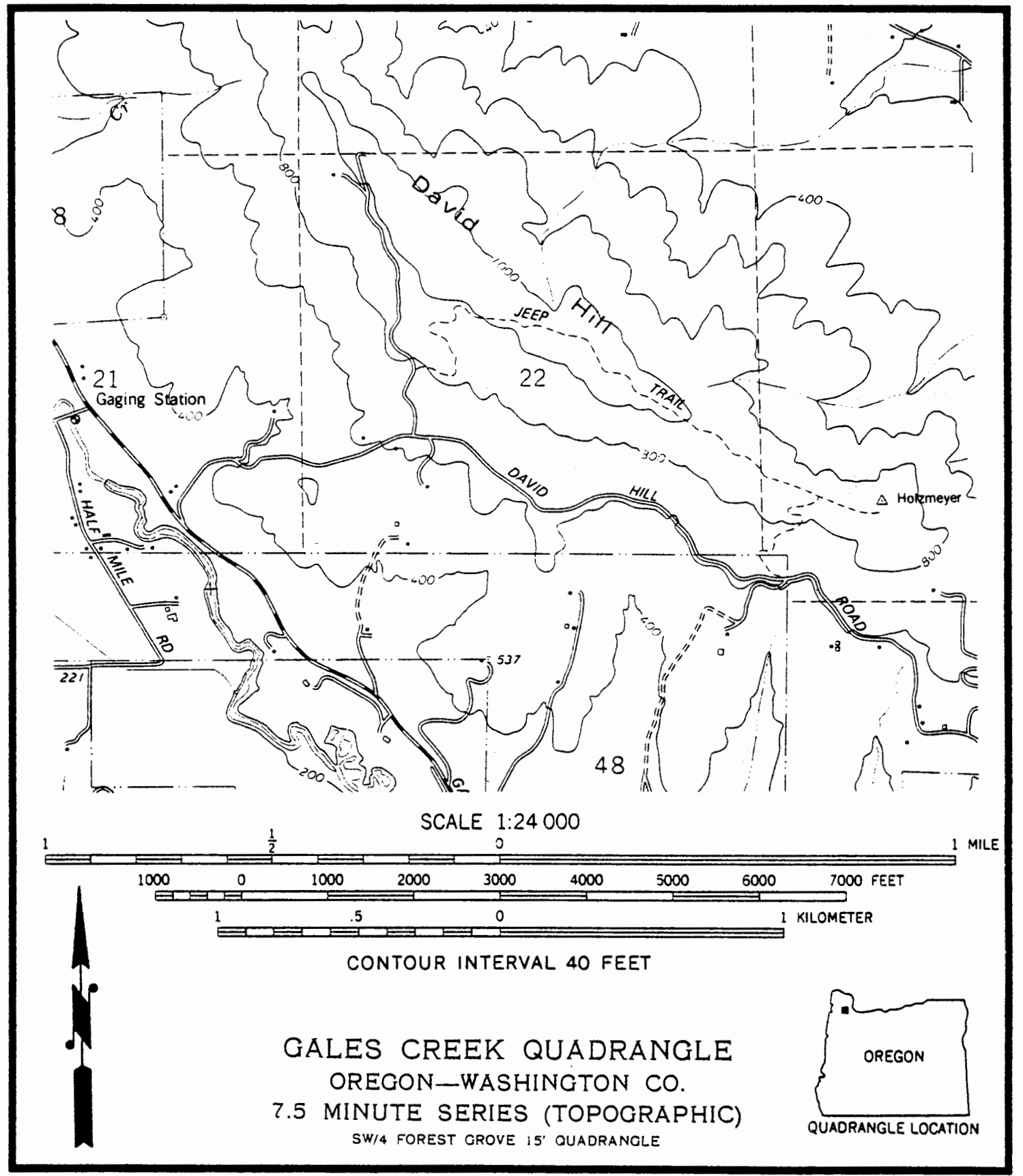

Fiqure 7. Approximate location of the David Hill Well, near the western edge of the Tualatin basin (Section 22, TIN, R4W). 


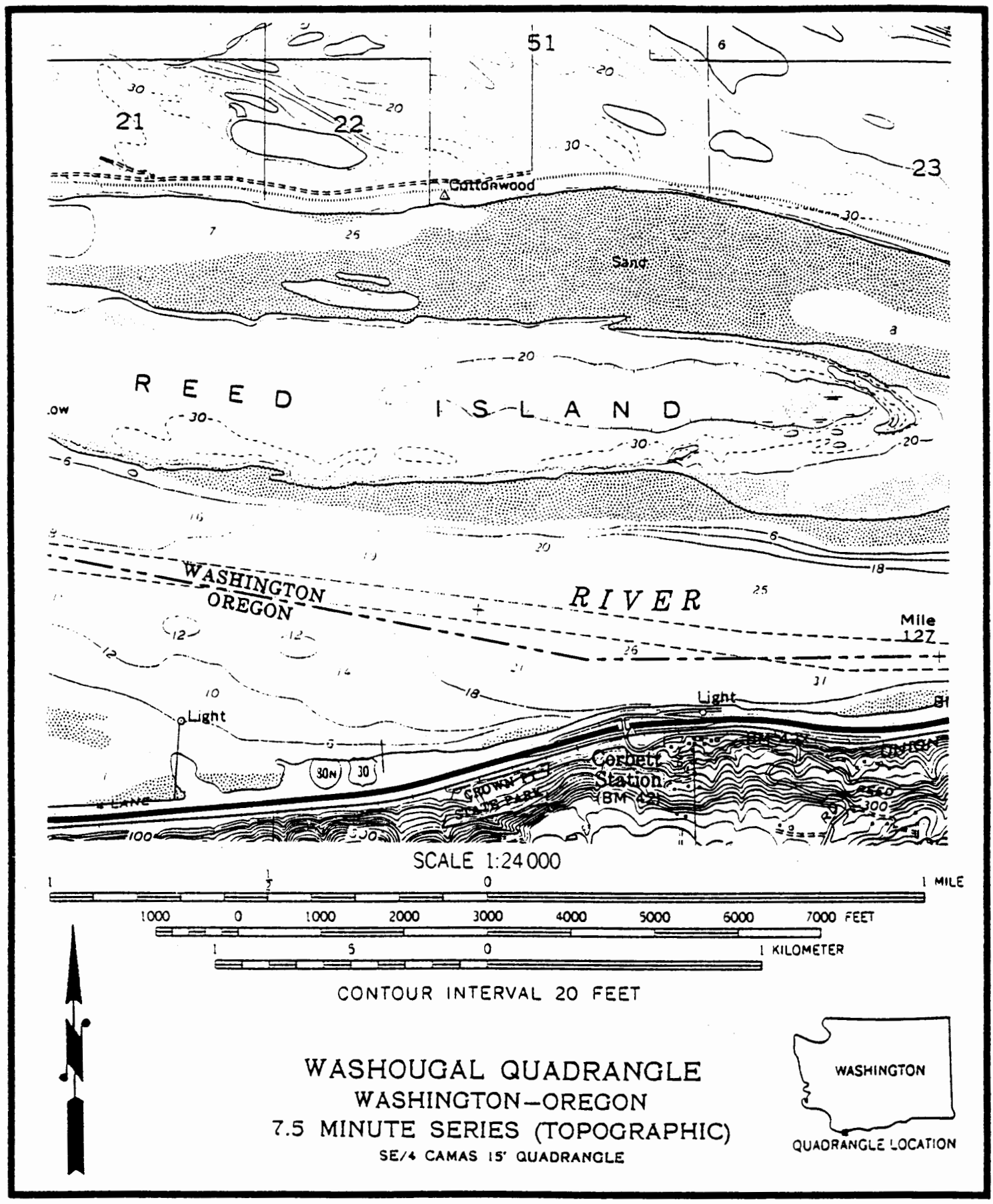

Figure 8. Approximate location of the two volcanic ash samples collected from Reed Island (Section 22, TIN, R4E). 
The names assigned to each outcrop sample include a letter/number combination to identify the outcrop location and the total number of outcrop samples collected to date. The names assigned to the core/chip samples include the name of the drill hole followed by the depth from which the sample was taken. As both DOGAMI and Trimet used English units (feet) to indicate depth on the drill hole logs, the samples collected for this study are also labeled by using the depth of the sample in feet.

\section{SAMPLE DESCRIPTION}

Four irradiations (93D, 93E, 93G, and 94A) were completed for this study. The standards included with the irradiation are as follows: CFA(1633a), Coal Fly Ash; BCR1, Columbia River basalt (Grande Ronde Basalt); and MAG-1, Marine Mud.

\section{Irradiation 93D}

Boring Lava and sediment samples were collected from Trimet drill core by the Spring 1993, Advanced Geochemistry Class at Portland State University for a class project. Thirty-nine samples were analyzed: 21 Boring Lava, 15 sediments, 3 standards (CFA, BCR1, and MAG-1). 
Irradiation $93 \mathrm{E}$

Boring Lava samples were collected from Trimet drill core and from outcrops located along the west side of the Tualatin Mountains. Thirty-nine samples were analyzed: 37 Boring Lava, 2 standards (BCRI and CFA).

\section{Irradiation $93 \mathrm{G}$}

Sediment samples were collected from Trimet drill core and from DOGAMI drill hole HBD1 located in the Tualatin basin. Thirty-nine samples were analyzed: 10 Trimet core, 26 HBD1 core, 3 standards (CFA, BCR1, and MAG-1) .

\section{Irradiation $94 \mathrm{~A}$}

Sediment samples were collected from DOGAMI drill core taken from numerous shallow holes in the Portland and Tualatin basins, and from DOGAMI drill hole MTD1 located in the Portland basin. Miscellaneous samples include one sample of bentonite drilling mud, two volcanic ash samples, one pre-CRBG sediment sample, and the three Boring Lava samples previously collected by Dr. Marvin Beeson. Fifty-seven samples were analyzed: 48 sediments, 2 volcanic ash, 1 drilling mud, 3 Boring Lava, 3 standards (CFA, BCRI, and MAG-1). 
SAMPLE PREPARATION

All samples and standards were prepared and analyzed in accordance with the Portland State University Radiation Safety Program (PSU, 1987). Three irradiations of 39 samples, and one irradiation of 57 samples were analyzed.

Each Boring Lava sample to be analyzed was prepared using the following procedure: A mechanical rock crusher was used to break the outcrop or core sample into pieces small enough to crush using a mortar and pestle. Clean, unweathered chips from the outcrop samples were powdered by hand using a mortar and pestle of hardened steel. To remove any drilling mud, clean, unweathered chips from core samples were cleaned ultrasonically for one to two minutes, then rinsed with tap water followed by distilled water, and dried prior to powdering with the mortar and pestle.

Each sediment sample to be analyzed was prepared using the following procedure: The sediment samples containing moisture were placed in an oven at approximately $75^{\circ} \mathrm{C}$ until dry. A mechanical rock crusher was used to break the samples into pieces small enough to crush using a mortar and pestle. Due to their fissility, sediment samples were not ultrasonically cleaned. Once dry, the sediment samples were also powdered by hand using a mortar and pestle of hardened steel. When all of the 
samples to be analyzed for each irradiation had been powdered, the samples were placed into containers appropriate for the irradiation process. Approximately one gram of each powdered sample was weighed and put into individual $1 / 2$ dram polyvials. The 1/2 dram polyvials were heat sealed to contain all material, and then rinsed in isopropyl alcohol to clean the surface. Once dry, the $1 / 2$ dram polyvials were put, one each, into a 2 dram polyvial for the first three irradiations (93D, 93E, and 93G). For the last irradiation (94A), two $1 / 2$ dram polyvials were placed into the 2 dram polyvial to allow for more samples to be irradiated at one time.

\section{ANALYSIS PROCEDURE}

Samples were irradiated at the Reed College Nuclear Reactor for 1 hour at approximately 250 kilowatts. Following irradiation, samples were left at the reactor for five days to allow the highly active, short-lived isotopes (Al-28, Mn-56, and $\mathrm{Na}-24)$ to decay to safe levels. On the sixth day, the samples were transported to Portland State University for analysis.

An EG\&G Solid State Photon Detector with a highpurity Germanium crystal was used for all analyses. Because different radioisotopes decay at different rates, information can be obtained for different elements by 
counting irradiated samples at several times after irradiation. The first analysis, or "first counts", for each irradiation was completed 5-7 days after irradiation in the nuclear reactor. Data were obtained for $\mathrm{K}, \mathrm{Na}$, As, U, La, and Sm. The second analysis, or "second counts", for each irradiation was completed 18-27 days after irradiation in the nuclear reactor. Data were obtained for $\mathrm{Rb}, \mathrm{Cs}, \mathrm{Sr}, \mathrm{Ba}, \mathrm{Fe}, \mathrm{Sc}, \mathrm{Cr}, \mathrm{Co}, \mathrm{Zr}, \mathrm{Hf}, \mathrm{Ta}, \mathrm{Th}, \mathrm{Zn}$, Ce, Nd, Eu, Tb, Yb, and Lu.

Geochemical data were entered into a computer spreadsheet. Numerous plots were generated in order to interpret the geochemical data and to identify and define geochemical groups. Scatter plots were generated using element concentrations and/or ratios of element concentrations. Chondrite plots were generated using the rare earth element ( $R E E$ ) concentrations normalized to the C1 Chondrite, and the position of the REE on the periodic table. C1 Chondrite values were taken from Ekambarum and others (1984). Both types of graphs aid in identifying geochemical groups by allowing patterns in the data to be more easily observed.

Hand drawn boundaries on the scatter plots show the differences and similarities between the identified geochemical groups. Hand drawn lines, connecting the points representing the REE normalized concentrations of 
each sample presented on a chondrite plot, also show the differences and similarities between the identified geochemical groups. The dashed lines on the chondrite plots represent the interpreted path of lines to and from those elements not having a calculated concentration. As this study deals primarily with the geochemistry of rock and sediments, the scatter plots and chondrite plots were the primary tools used in the interpretation of the data. However, a brief visual inspection of hand samples was conducted both to aid in the interpretation of the geochemistry, and to confirm what the geochemistry indicated. The geographical location from which the sample was collected was also noted to aid in the interpretation of the geochemical data.

Once geochemical groups were recognized, cross sections, stratigraphic columns, and distributions of geologic units, were constructed using all of the available data (geochemistry, magnetic polarity, lithology, and radiometric age). Basic statistical tests ( $F$ and $T$ tests) were also conducted on the identified geochemical groups. 
DATA AND RESULTS

Trace element geochemical data were obtained for all 163 samples analyzed using INAA. Data were collected for the following elements:

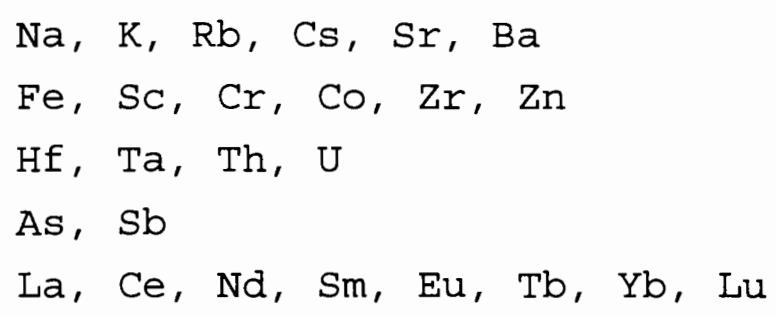

Due to human error made during analysis, samples b557-3852, b557-80-94, b541-27, and LOD6-95-110 do not have complete data sets. The locations from which b557-38-52, b557-80-94, and b541-27 were collected, were re-sampled. LOD6 was not re-sampled and has only a partial data set. Additionally, some samples do not have complete data sets as there was not sufficient information obtained from the detector with which to calculate concentrations for some elements.

Those elements having less than ten percent counting error are considered the most reliable data and include $\mathrm{Ba}, \mathrm{Ce}, \mathrm{Co}, \mathrm{Cr}, \mathrm{Cs}, \mathrm{Eu}, \mathrm{Fe}, \mathrm{Hf}, \mathrm{La}, \mathrm{Na}, \mathrm{Sc}, \mathrm{Sm}, \mathrm{Tb}$, and Th. Many of these elements were very useful in defining geochemical groups. Most of the remaining elements have counting errors greater than ten percent, and were 
generally not useful in defining geochemical groups. A complete listing of geochemical data is contained in Appendices A through E.

Additional data sets are available for the Boring Lava samples. The data sets include age dates, magnetic polarity, and XRF geochemistry (Tables II-IV).

The number and type of data sets available for the Boring Lava (XRF and INAA geochemistry, age dates, and magnetic polarity) allowed for the distinction of three Boring Lava units. The XRF data and the age dates obtained prior to this study indicated that there were two, and possibly three units. The magnetic polarity and INAA data confirmed that there were three units. The elements SC, La, Ce, Cr, Eu, and Co, were the most useful in distinguishing the three units. Geochemical data for the Boring Lava samples are presented in Appendix A.

The data available for the sediment samples include the INAA geochemistry, and the location and depth from which the sample was collected. Seven geochemical groups of sedimentary materials were identified. The useful elements for distinguishing the sediment groups included Hf, La, Sm, Th, Fe, Cr, and Co. Geochemical data for the sediment samples is presented in Appendices B through $E$. 
Table II. Age dates and sample numbers for the Boring Lava (Data from Rick Conrey. Sample $92 \mathrm{~TB} 5$ was also dated by the United States Geological Survey).

\begin{tabular}{ll}
\hline Sample Number & $\frac{\text { Age Date }}{0.26+/-.11 \mathrm{Ma}}$ \\
B14-37.5 & $0.96+/-.03 \mathrm{Ma}$ \\
B12-119 & $0.86+/-.04 \mathrm{Ma}$ \\
B12-94 & $0.97+/-.14 \mathrm{Ma}$ \\
B537-155 & $2.44-2.6 \mathrm{Ma}$ \\
92 TB5 & \\
\hline
\end{tabular}

Table III. Magnetic polarity and sample numbers for the Boring Lava.

NORMAL Magnetic Polarity

$\begin{array}{ll}\text { b5 } 58-28.5 & \text { SS2 } \\ \text { b539-42 } & \text { CY5 } \\ \text { b540-34 } & \text { CY6 } \\ \text { b556-57 } & \text { BA7 } \\ \text { b556-95 } & \text { BU8 } \\ \text { b557-165 } & \text { SH9 } \\ \text { b557-211 } & \text { HWY26-2 } \\ \text { b557-213 } & \text { HWY26-3 } \\ \text { b561-98 } & \text { HWY26-4 } \\ \text { b561-135 } & \text { ODOT-K108-48-49 } \\ \text { b564-115 } & \end{array}$

B13-76.2

B13-104.7

B19-46

B535-105

B538-91

B54 1-27

B557-32

B557-63

B557-93.5

B561-71.7

B561-90

B561-123.5

B562-74.3

B562-198.5

REVERSE Magnetic Polarity
b538- 176
b539-167. 7
b540-213
b561-166
b561-172
b564-170

CR3

92 TB5

MB88-186

MB88-190

B13- 155

B535-209

B537-40.3

B555-70

B555-119.5

B565-154 
Table IV. X-ray fluorescence data for selected Boring Lava samples (Data from Marvin Beeson; samples analyzed at Washington State University).

Sample

Number

B12-94 B12-119 B538-91 B555-70 B561-90 B562-198

$$
\begin{aligned}
& \mathrm{SiO}_{2} \\
& \mathrm{Al}_{2} \mathrm{O}_{3} \\
& \mathrm{TiO}_{2} \\
& \mathrm{FeO}^{*} \\
& \mathrm{MnO} \\
& \mathrm{CaO} \\
& \mathrm{MgO} \\
& \mathrm{K}_{2} \mathrm{O} \\
& \mathrm{Na}_{2} \mathrm{O} \\
& \mathrm{P}_{2} \mathrm{O}_{5}
\end{aligned}
$$

$\mathrm{Ni}$

$\mathrm{Cr}$

$\mathrm{SC}$

$\mathrm{V}$

$\mathrm{Ba}$

$\mathrm{Rb}$

$\mathrm{Sr}$

Zr

$Y$

$\mathrm{Nb}$

$\mathrm{Ga}$

$\mathrm{Cu}$

$\mathrm{Zn}$

$\mathrm{Pb}$

La

$\mathrm{Ce}$

$\mathrm{Th}$

$$
\text { Normalized Results (Weight \%) }
$$

$\begin{array}{rrrrrr}52.04 & 52.43 & 54.60 & 52.77 & 52.10 & 51.80 \\ 16.91 & 17.86 & 17.11 & 17.82 & 17.40 & 16.75 \\ 1.30 & 1.31 & 1.29 & 1.32 & 1.40 & 1.33 \\ 8.16 & 8.24 & 7.80 & 8.05 & 8.25 & 8.14 \\ 0.13 & 0.14 & 0.13 & 0.14 & 0.13 & 0.13 \\ 8.91 & 8.67 & 7.72 & 8.55 & 8.38 & 8.76 \\ 7.31 & 6.41 & 5.86 & 6.23 & 7.01 & 7.72 \\ 1.18 & 0.71 & 0.98 & 0.77 & 1.19 & 1.21 \\ 3.71 & 3.97 & 4.17 & 4.09 & 3.74 & 3.81 \\ 0.36 & 0.27 & 0.32 & 0.27 & 0.39 & 0.35\end{array}$

Trace Elements (ppm)

$\begin{array}{rrrrrr}158 & 109 & 108 & 109 & 156 & 149 \\ 251 & 162 & 165 & 153 & 258 & 235 \\ 20 & 24 & 22 & 28 & 23 & 27 \\ 172 & 188 & 147 & 184 & 197 & 187 \\ 293 & 197 & 298 & 228 & 343 & 339 \\ 15 & 6 & 10 & 5 & 15 & 15 \\ 1024 & 655 & 776 & 721 & 966 & 1028 \\ 159 & 139 & 155 & 144 & 170 & 160 \\ 15 & 24 & 19 & 23 & 19 & 16 \\ 13 & 9 & 9 & 9 & 13 & 14 \\ 18 & 18 & 20 & 18 & 23 & 18 \\ 54 & 50 & 50 & 57 & 67 & 49 \\ 76 & 75 & 94 & 77 & 83 & 73 \\ 2 & 1 & 2 & 3 & 5 & 1 \\ 38 & 13 & 28 & 15 & 28 & 23 \\ 48 & 29 & 41 & 42 & 72 & 65 \\ 3 & 2 & 1 & 2 & 4 & 4\end{array}$

* Total $\mathrm{Fe}$ is expressed as FeO. 


\section{BORING LAVA INTERPRETATION}

\section{INTRODUCTION}

Four separate data sets were used to examine the Boring Lava along the west side of the Tualatin Mountains, near Highway 26. XRF geochemical data and age dates were obtained from previous studies. INAA geochemical data were obtained during this study. Magnetic polarity data were obtained both during previous work and during this study .

\section{AGE DATES}

Five of the samples analyzed by INAA, were dated using a K-Ar dating method (Conrey, 1995; personal communication). The five dates are listed in Table II. Three general dates are established and presented below in Table V. The locations of the dated samples are shown on Figures 3 and 6 . 
Table V. Approximate ages of the five samples that have age dates.

\begin{tabular}{||c|c|c|}
\hline $\begin{array}{c}\text { Approximate Date } \\
\text { (years) }\end{array}$ & $\begin{array}{c}\text { Radiometric Date } \\
\text { (Ma) }\end{array}$ & $\begin{array}{c}\text { Sample } \\
\text { Number }\end{array}$ \\
\hline 250,000 & $0.26+/-.11$ & B14-37.5 \\
\hline $\begin{array}{c}750,000 \\
\text { to } \\
1,000,000\end{array}$ & $0.96+/-.03$ & B12-119 \\
$2,500,000$ & $0.86+/-.04$ & B12-94 \\
\hline & $0.97+/-.14$ & B537-155 \\
$2.44-2.6$ & 92 TB5 \\
\hline
\end{tabular}

\section{MAGNETIC POLARITY}

Magnetic polarity data were recorded for each sample collected for this study (Table IV). Magnetic polarities for TriMet drill core were recorded at the time the drill core was extracted by TriMet personnel. Magnetic polarities for outcrop samples were recorded at the time of collection using a fluxgate magnetometer.

\section{XRF GEOCHEMISTRY}

XRF data (Beeson, 1993; personal communication) reveal at least two different geochemical groups as seen in both major and trace element geochemistry (Table IV). 
As mentioned previously, XRF data for the trace elements showed that INAA would also be useful in differentiating between Boring Lava units.

\section{INAA GEOCHEMISTRY}

Geochemical data for the Boring Lava are presented in Appendix A. Scatter plots of INAA data generally show two to three recurring groups (Figures 9, 10, and 11). These groups are most clearly defined on Figure 9 (Scandium vs. Cerium). Samples at the edges of the groups, which may plot away from the main cluster, tend to represent pyroclastic material associated with the eruption of that unit, or may represent weathered flow boundaries.

Several exceptions are obvious on Figure 9, and are visible on Figures 10 and 11 as well. Sample KAl was collected from the northern-most section of the Boring Lava considered for this study. The outcrop is weathered, bleached, and very rubbly. The geochemistry of this sample is no doubt obscured by weathering effects. Thus, it always plots away from the above three groups.

Sample CLAR-110-120 was collected previous to this study from drill cuttings taken from a water well at the Claremont Golf Course. Though the chips appear to be of Boring Lava, the powdered sample does not look like other powdered Boring Lava samples. It too tends to plot away 


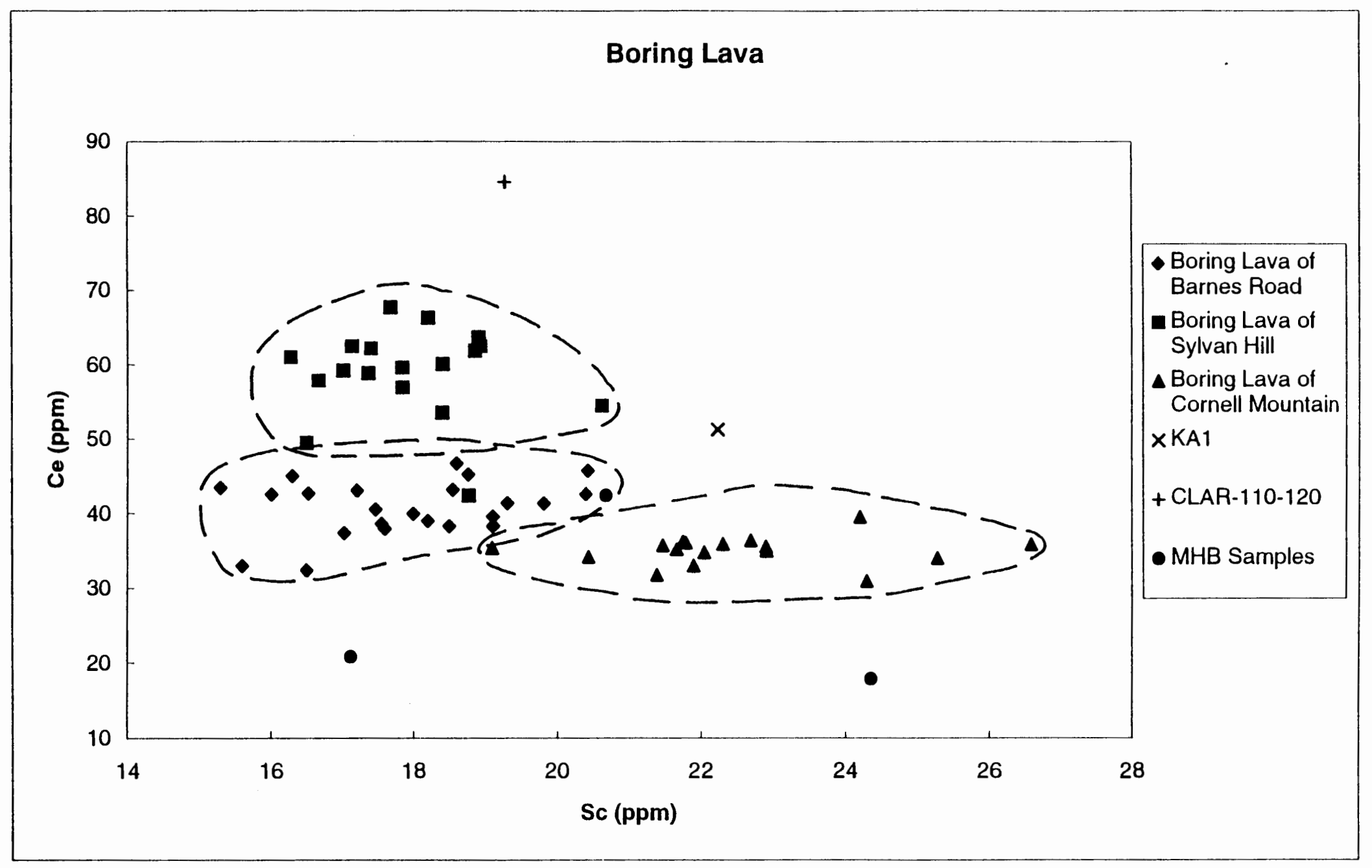

Figure 9. Boring Lava Scatter Plot (Scandium vs. Cerium). 


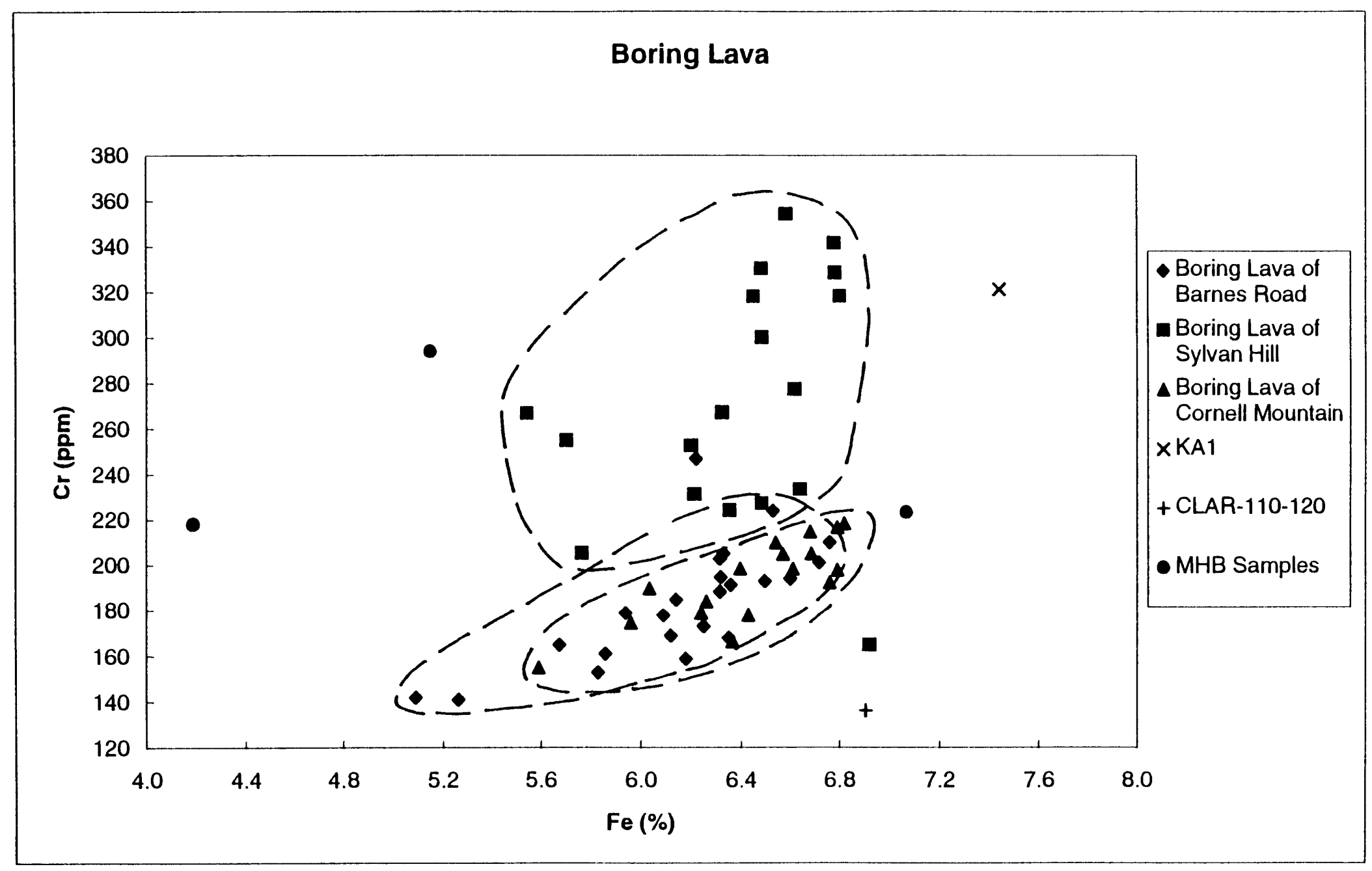

Figure 10. Boring Lava Scatter Plot (Iron vs. Chromium). 


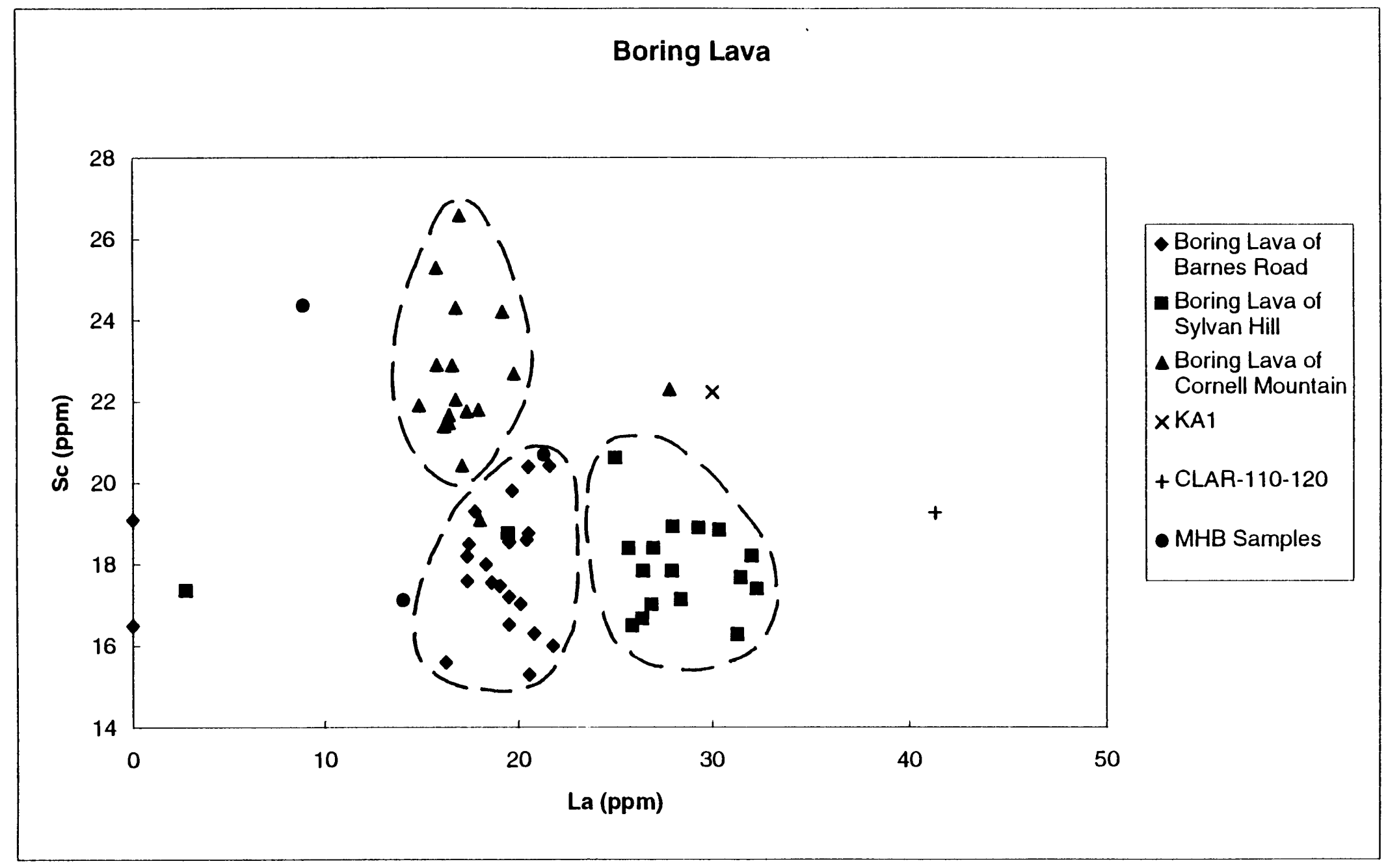

Figure 11. Boring Lava Scatter Plot (Lanthanum vs. Scandium). 
from or on the margins of the above three groups, and may represent a separate geochemical group.

Samples MB88-186, MB88-190, and 92TB5 are outcrop samples from Mt. Sylvania, Cookes Butte, and the Oregon City plateau, respectively, collected previous to this study (labeled as MHB samples on Figure 9-11). They are interpreted to have erupted from separate vents and do not consistently plot with the other groups.

Table VI presents age, magnetic polarity, and selected INAA data for the four samples along the light rail tunnel alignment which have age dates. From these data, three Boring Lava units are identified along the west side of the Tualatin Mountains near Highway 26: the Boring Lava of Barnes Road, the Boring Lava of Sylvan Hill, and the Boring Lava of Cornell Mountain. The names chosen for the three units are based primarily on the identified surface distribution, and the relation of each unit to a geographic or cultural feature, as shown in Figures 12 and 13 .

Using all available data, differentiating between the three Boring Lava units is straightforward. The Boring Lava of Sylvan Hill and the Boring Lava of Cornell Mountain both yield approximately the same radiometric age. However, they have different magnetic polarities and are chemically distinct from one another. The difference 
in magnetic polarity is attributed to the last major magnetic reversal, which occurred approximately $0.80 \mathrm{Ma}$ years ago. The Boring Lava of Barnes Road, though it is chemically similar to the Boring Lava of Cornell Mountain, has a normal magnetic polarity and is approximately 0.50 Ma younger. Knowing these differences, geographic distribution and stratigraphic position of the three Boring Lava units was determined in the southern portion of the study area using both the drill hole and outcrop sample locations (Figures 12,13 and 14).

Because there is very little surface exposure of Boring Lava along the west side of the Tualatin Mountains, the pictured distributions of the three Boring Lava units are based primarily on the existing topography. A topographic map showing the same Boring Lava distributions is presented in Figure 13. Figure 14 shows the subsurface distribution of the three Boring Lava units along the tunnel alignment. The contacts and the resulting, apparent structures shown in Figure 14 are based on the geochemistry, radiometric age, magnetic polarity, and the boring logs presented in Squier Associates (1992). The dark, solid colors (blue, red, and green) on Figure 14 indicate solid rock while shaded areas of the same color represent rubbly or weathered zones. As CRBG units were not addressed in this study, the CRBG units and the 
structures within them and bounding them, on Figure 14, are presented as they are shown in Squier Associates (1992).

Table VI. Magnetic polarity and selected INAA data for the four samples along the tunnel alignment which have age dates.

Sample

Number

B12-94

B12-119

B14-37. 5

B537-155

Age (Ma)

$0.86+.04$

$0.96+.03$

$0.26+.11$

$0.97+.14$

Magnetic

Polarity

NORMAL

REVERSE

NORMAL

REVERSE

selected INAA trace element concentrations (ppm)

$\begin{array}{lrrrr}\text { Sr } & 1005 & 860 & 788 & 789 \\ \mathrm{Cr} & 319 & 205 & 205 & 217 \\ \mathrm{Co} & 41 & 37 & 30 & 36 \\ \mathrm{Th} & 3.7 & 1.6 & 1.9 & 1.8 \\ \mathrm{La} & 28.4 & 16.3 & 20.6 & 18.0 \\ \mathrm{Ce} & 62.5 & 35.7 & 43.5 & 35.4 \\ \mathrm{Sm} & 5.94 & 4.34 & 5.18 & 4.49 \\ \mathrm{Eu} & 1.92 & 1.58 & 1.70 & 1.53 \\ \mathrm{Lu} & 0.25 & 0.50 & 0.28 & 0.39\end{array}$




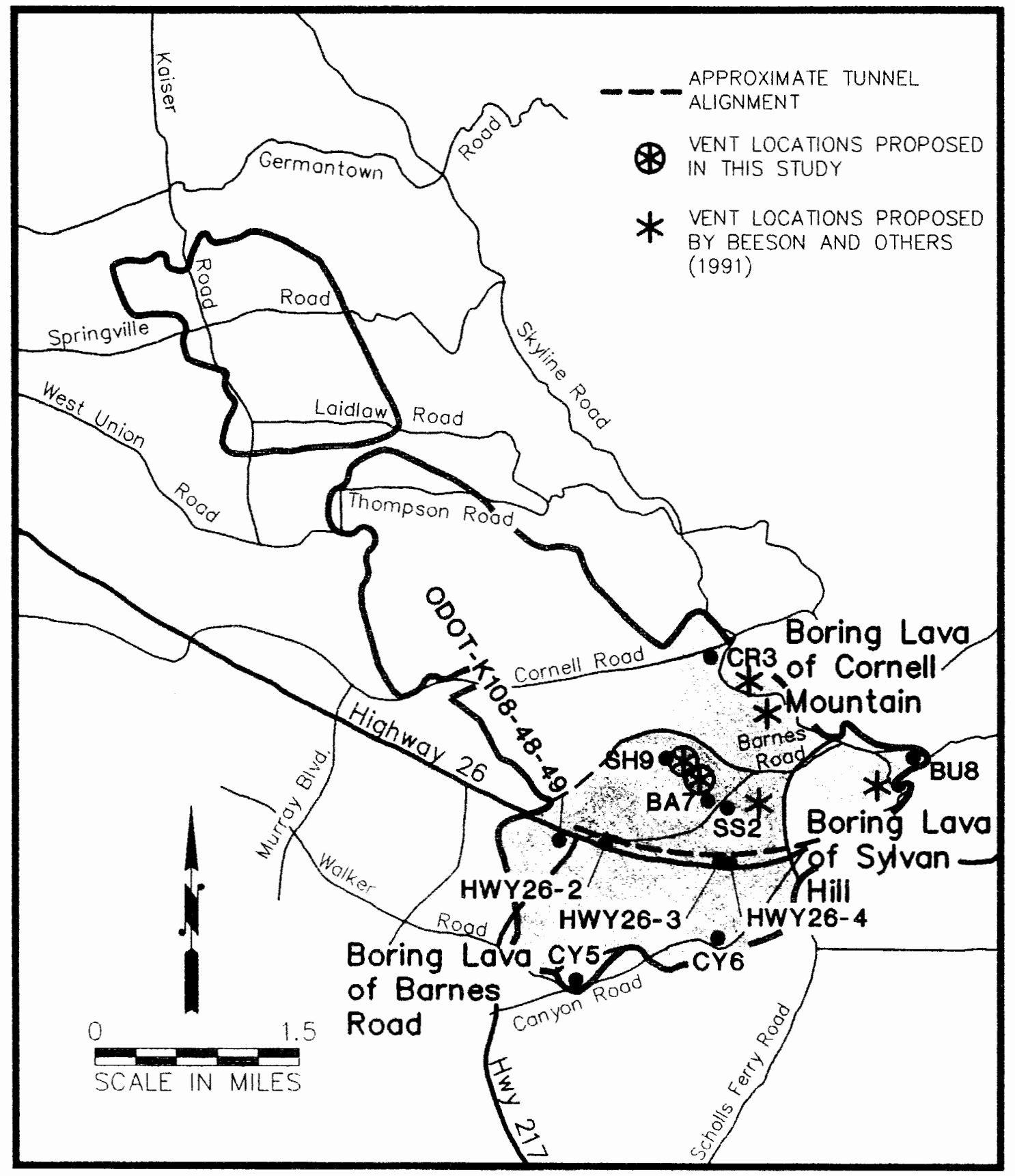

Figure 12. Surface distribution of Boring Lava (road map). Boring Lava outline from Trimble (1963). 


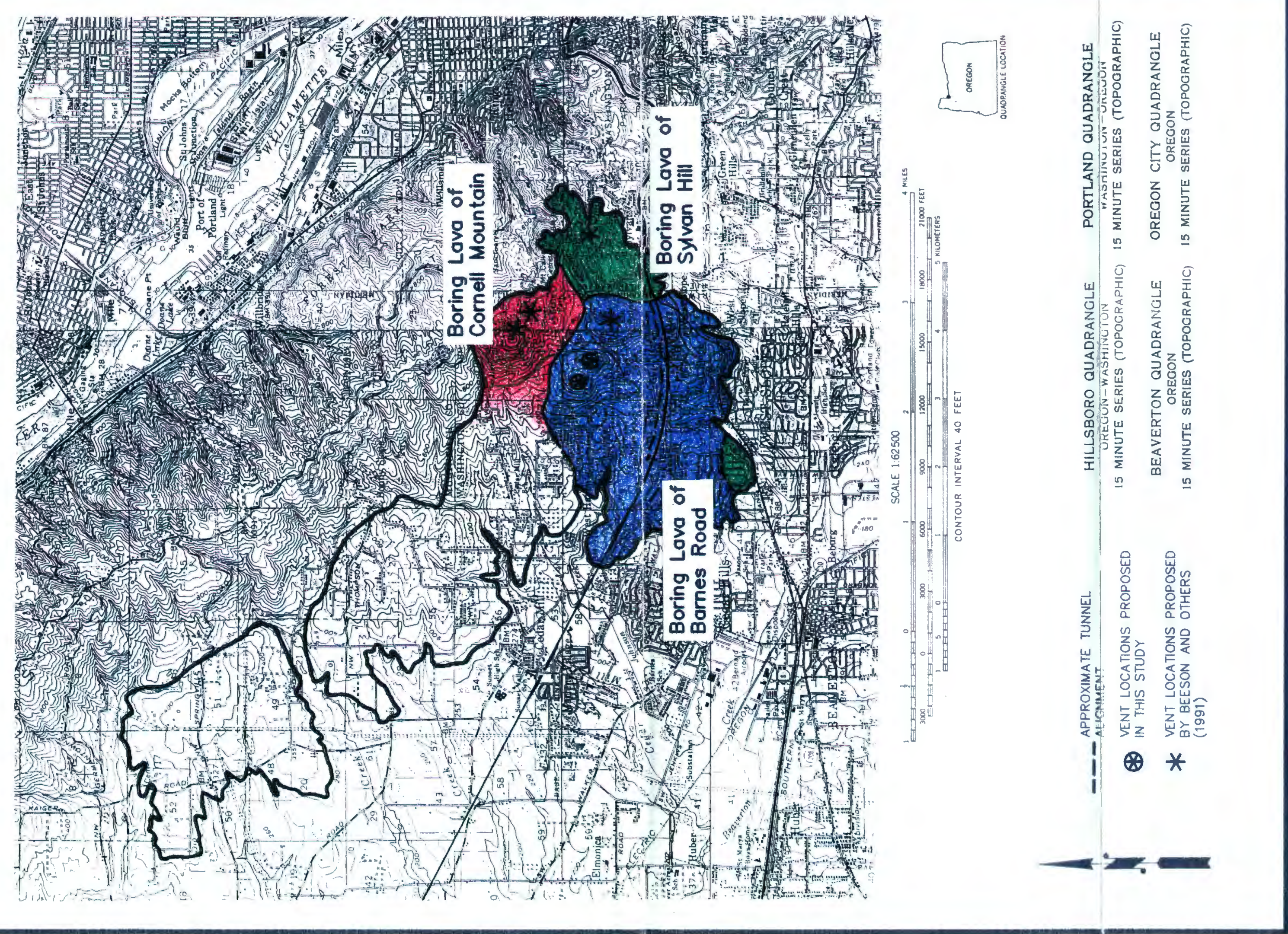




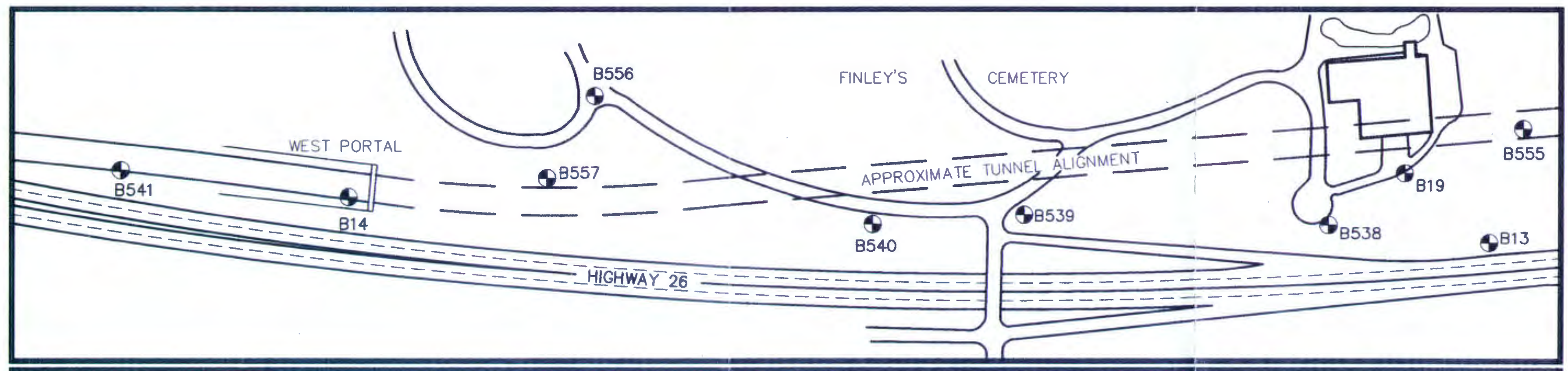

FINLEY'S CEMETERY

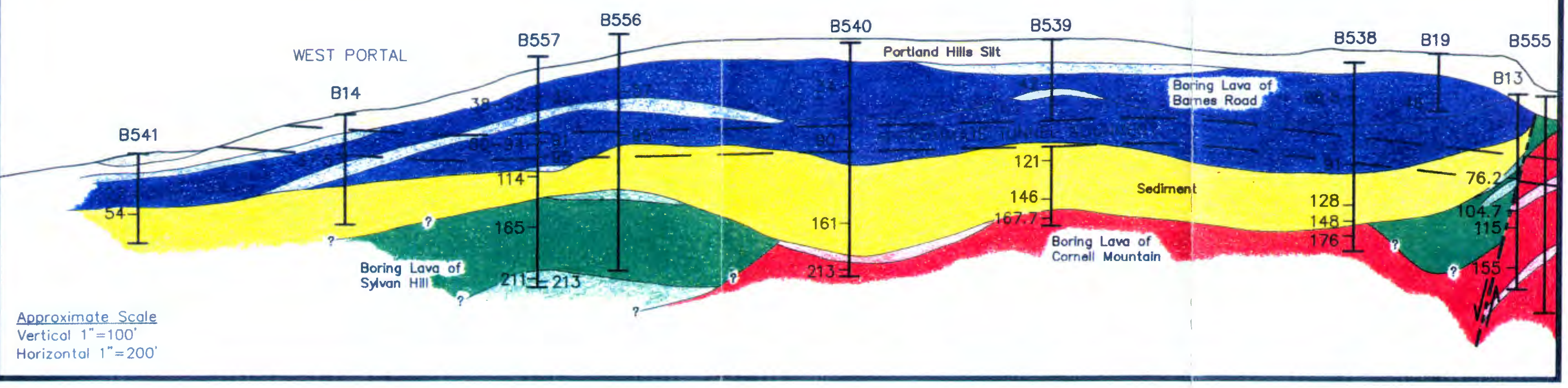

Figure 14. Distribution of Boring Lava along the west end of Line Section 5A of the Trimet tunnel alignment. Modified after Squier Associates (1992). 

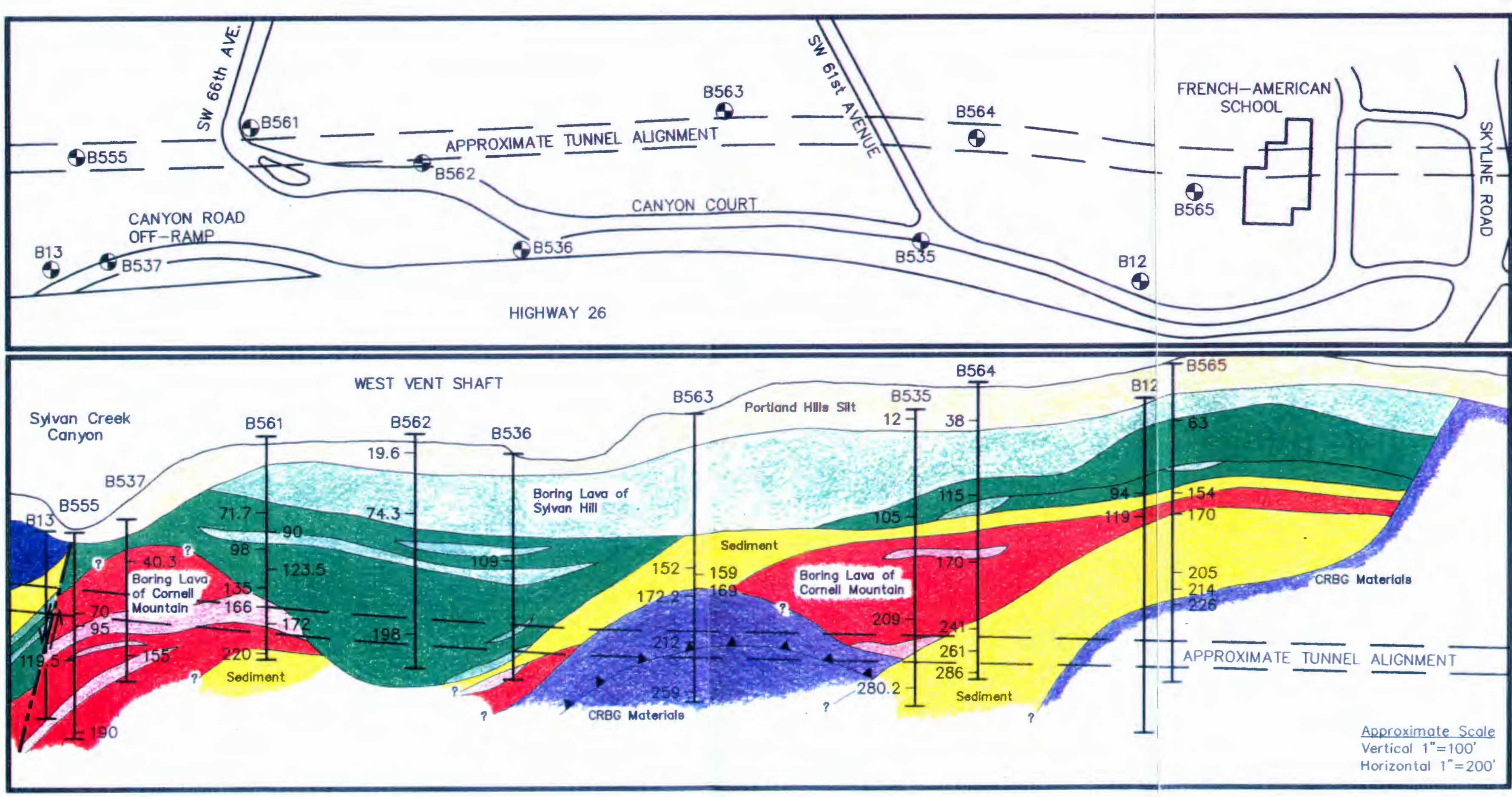

Figure 14 continued. 
STATISTICAL ANALYSIS

Basic statistical analysis was completed for the three geochemical groups, which were chosen based on geochemistry, age, and magnetic polarity. The statistical analysis was completed to show that the chosen geochemical groups are indeed distinguishable from one another. F tests were completed initially to examine the equality of the variances between the groups. Where the $F$ test failed to reject the equality of the variances, $T$ tests were conducted to compare the means of the groups. Statistical analysis is presented in Appendix F.

Complete data sets were not available for all of the analyzed samples. As a result, only those samples having complete data sets were used to calculate the mean for that group. In addition, not all elements that had geochemical data available were used in the comparisons. Element choice was based on the counting error and the completeness of the data. Those elements having less than ten percent counting error and complete data sets were used in the statistical analysis. The elements used were $\mathrm{Na}, \mathrm{Cs}, \mathrm{Ba}, \mathrm{Fe}, \mathrm{Sc}, \mathrm{Cr}, \mathrm{Co}, \mathrm{Hf}, \mathrm{Th}, \mathrm{La}, \mathrm{Ce}, \mathrm{Sm}, \mathrm{Eu}$, and $\mathrm{Tb}$.

Based on the results of the F tests, run using a 5\% level of significance, the equality of the variances was rejected for each set of Boring Lava units compared. No T 
tests were necessary. Thus, the three, previously discussed groups, can be considered separate, distinct geochemical groups.

\section{DISCUSSION}

Figures 12, 13, and 14, show the distribution of the Boring Lava both stratigraphically and geographically, and suggest a particular sequence of events. The radiometric age, magnetic polarity, and location of the Boring Lava of Cornell Mountain indicate that it erupted first, and flowed south and southwest. Based on the existing topography, it also likely flowed west and northwest, although there are few geochemical data to support this hypothesis. Two vent locations were proposed by Beeson and others (1991).

Based on radiometric age and magnetic polarity, the Boring Lava of Sylvan Hill erupted shortly after the Boring Lava of Cornell Mountain, from a vent located to the southeast of the area from where the Boring Lava of Cornell Mountain erupted. The vent location for the Boring Lava of Sylvan Hill was proposed by Beeson and others (1991). The Boring Lava of Sylvan Hill also appears to have flowed primarily south and southwest, although small amounts appear to extend to the north and east. A small tongue of the Boring Lava of Sylvan Hill is 
tentatively identified near the southwestern-most corner of the study area, near the intersection of Highway 217 and Walker Road (Figures 12 and 13).

Based on radiometric age alone, the Boring Lava of Barnes Road erupted most recently. There are three vent locations from which the Boring Lava of Barnes Road erupted, located to the west of the eruption points of the other two Boring Lava units. One of the three vent locations was proposed by Beeson and others (1991). Two of the vent locations are proposed based on the information obtained from this study, specifically, outcrop and core geochemistry and topography. The identified distribution of the Boring Lava of Barnes Road is the most extensive, covering much of the west flank of the Tualatin Mountains on either side of Highway 26 (Figures 12 and 13).

In the subsurface, the same sequence is observed (Figure 14). The Boring Lava of Cornell Road underlies the Boring Lava of Sylvan Hill and the Boring Lava of Barnes Road throughout the entire area shown in the cross section. In Trimet drill holes B13 and B561, at depths of approximately 105 and 140 feet respectively, the Boring Lavas of Cornell Mountain and Sylvan Hill are in contact with one another where the Boring Lava of Cornell Mountain directly underlies the Boring Lava of Sylvan Hill. In the 
eastern half of the cross section, a sediment layer separates the two older Boring Lava units. Based on the radiometric ages and magnetic polarities of the two older Boring Lava units, this sediment layer must have been deposited around the time of the most recent magnetic reversal (approximately $0.80 \mathrm{Ma}$ ).

Based on the contacts presented in Figure 14, it appears that a period of deformation/structural activity took place between the time of the eruption of the Boring Lavas of Cornell Mountain and Sylvan Hill, and the Boring Lava of Barnes Road. The difference in the ages of the two older Boring Lava units and the younger Boring Lava unit would provide approximately 0.50 Ma years for uplift and erosion, deposition of sediments, and structural deformation to occur. The upper surface of the two older Boring Lava units appears rather undulatory, and both of the older Boring Lava units are cut by a fault.

The youngest unit, the Boring Lava of Barnes Road, is present only in the western half of the cross section, which agrees with its identified surface distribution. It overlies both a sediment layer and the two older Boring Lava units. Because the ages of the Boring Lava units bounding this sediment layer are known, the age of the sediment layer in the western half of the cross section, is constrained to between approximately 0.25 Ma and 1 Ma. 
Based on the presented cross section, the Boring Lava of Barnes Road is not cut by the fault that cuts the older Boring Lavas of Sylvan Hill and Cornell Mountain.

The fault shown on Figure 14, in association with the Sylvan Creek Canyon near the middle of the cross section, is not shown on the surface maps in Figures 12 and 13 . The fault would be located near the contact of the Boring Lavas of Barnes Road and Sylvan Hill along the Trimet tunnel alignment on Figures 12 and 13. Beeson and others (1991) inferred a fault in this area. However, no field observations were made as a part of this study. The contacts shown are chosen based primarily on the existing topography and outcrop geochemistry. The result is that only one point exists on the surface maps that has information available (i.e. boring logs, magnetic polarity, and geochemistry) to suggest that a fault might exist. As such, no line could be drawn from this point to other such points to indicate where a fault might be located. 
SEDIMENT GEOCHEMISTRY AND INTERPRETATION

\section{INTRODUCTION}

Interpretation of the sediment geochemistry is not as straightforward as the interpretation of the Boring Lava geochemistry. Many factors can control the nature of sediment deposition. Particle size, shape, and density, water and/or wind velocity, load of the transporting medium (water vs. wind), local and/or regional volcanic activity, and plant/animal interaction are only a few. The deposition of sediments in the Portland area has Iikely been affected by all of the listed variables, and more. Nevertheless, it has been possible to identify several groupings among the analyzed samples. In particular, it is the amount of volcanic material in the samples analyzed, that has played a key role in the interpretation of the geochemical data.

\section{SHALLOW SEDIMENT AND MISCELLANEOUS SAMPLES}

Geochemical data for the shallow sediment and miscellaneous samples are presented in Appendix B. Shallow sediment samples include samples taken from Trimet core and DOGAMI shallow drill holes. The top 250 feet of 
the Portland International Airport Drill Hole (MTD1) is included in the analysis of this data set, but is listed in a separate appendix (Appendix D). Miscellaneous samples include two volcanic ash samples collected from Reed Island in the Columbia River east of the Sandy River Delta, a sample of pre-CRBG sediment collected from the western edge of the Tualatin basin, a sample of bentonite drilling mud, and three samples of sediment, one each of Sandy River Mudstone, Portland Hills Silt, and Missoula Flood sediments, collected from type localities or areas where positive identification of that type of sediment was achieved.

The bentonite drilling mud was analyzed to examine its geochemistry in order to identify and evaluate the potential contamination effects of drilling mud remaining on core samples when they were analyzed using INAA. Although the sample of drilling mud was determined to have very high concentrations of Th (up to $36 \mathrm{ppm}$ ), none of the other analyzed sediment samples plotted in groups that appeared skewed toward the position of the bentonite drilling mud sample. Thus, it does not appear that any drilling mud remaining on the analyzed samples significantly affected sample geochemistry.

Scatter plots generally show several broad groups (Figures 15-20). Sample geochemistry was compared with 


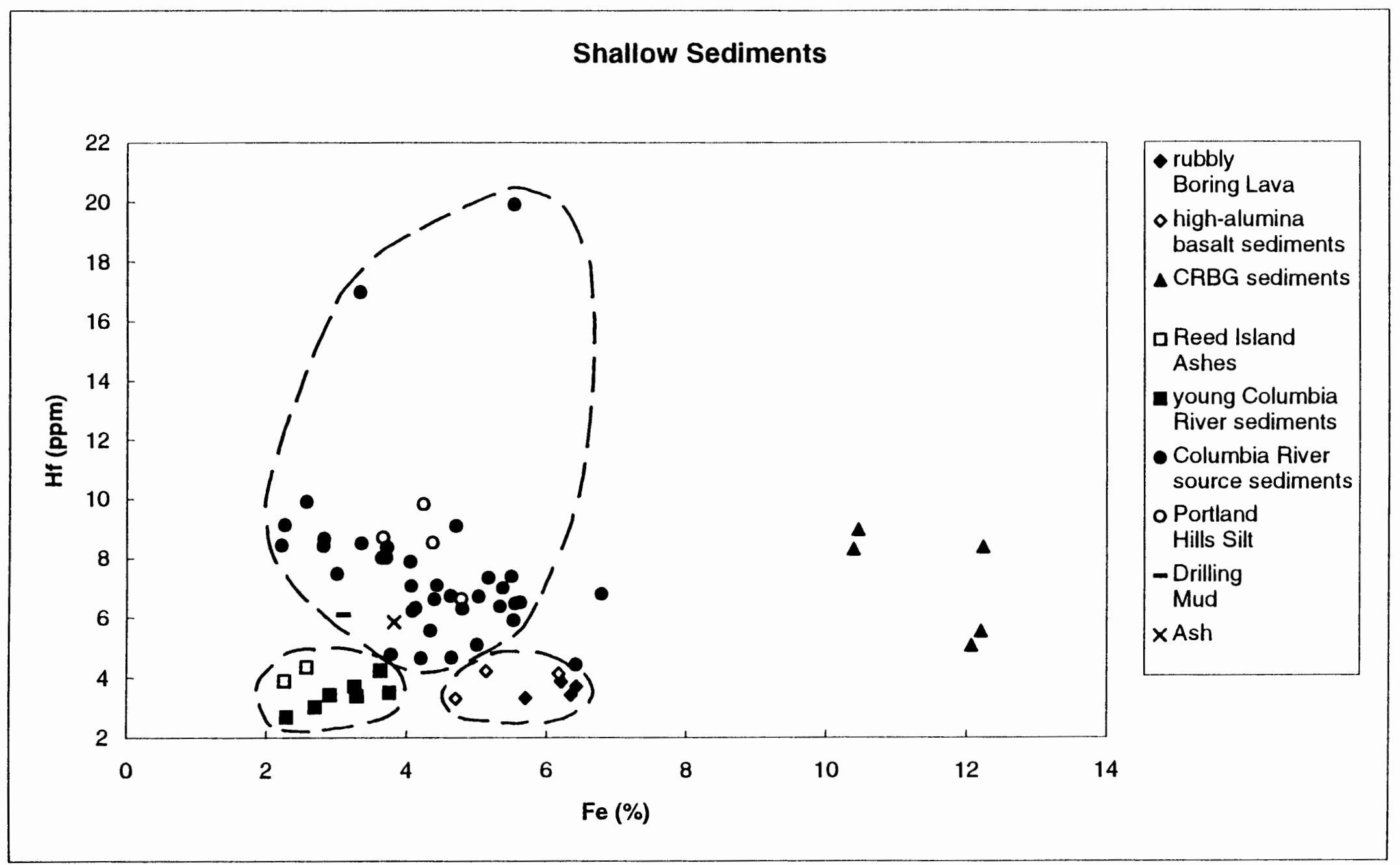

Figure 15. Shallow Sediments Scatter Plot (Iron vs. Hafnium). 


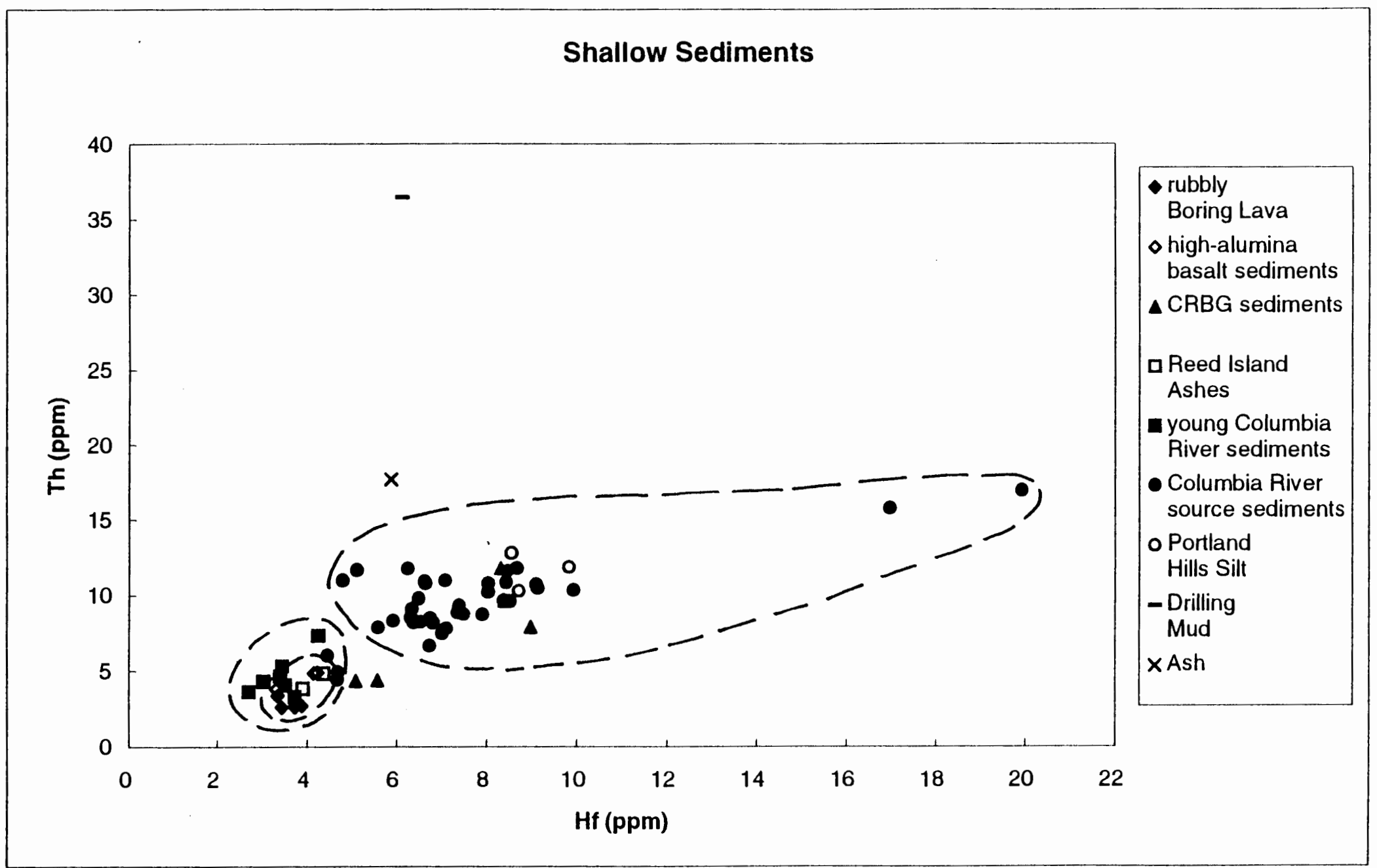

Figure 16. Shallow sediments scatter Plot (Hafnium vs. Thorium). 


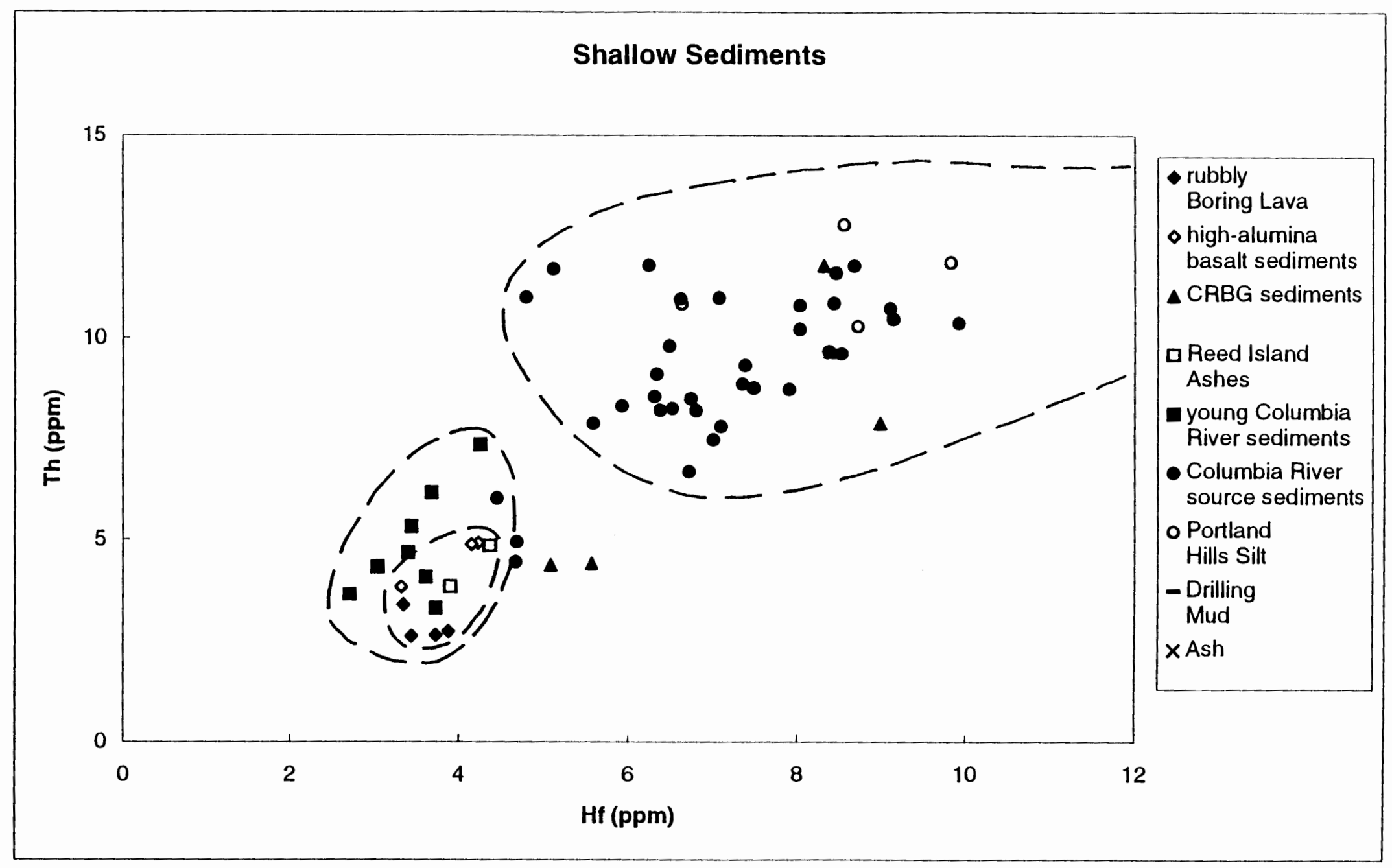

Figure 17. Shallow Sediments Scatter Plot Closeup (Hafnium vs. Thorium). 


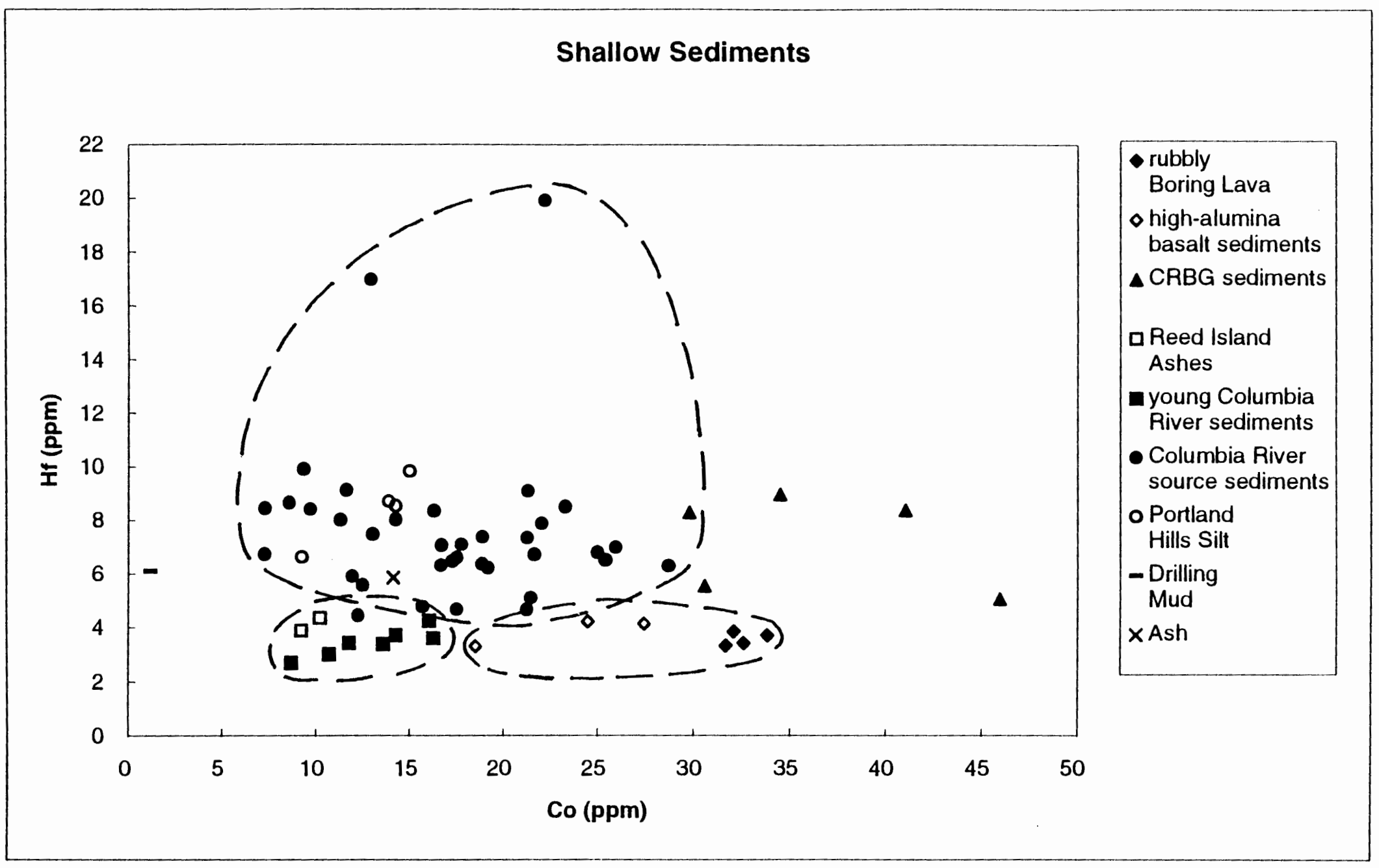

Figure 18. Shallow sediments Scatter plot (Cobalt vs. Hafnium). 


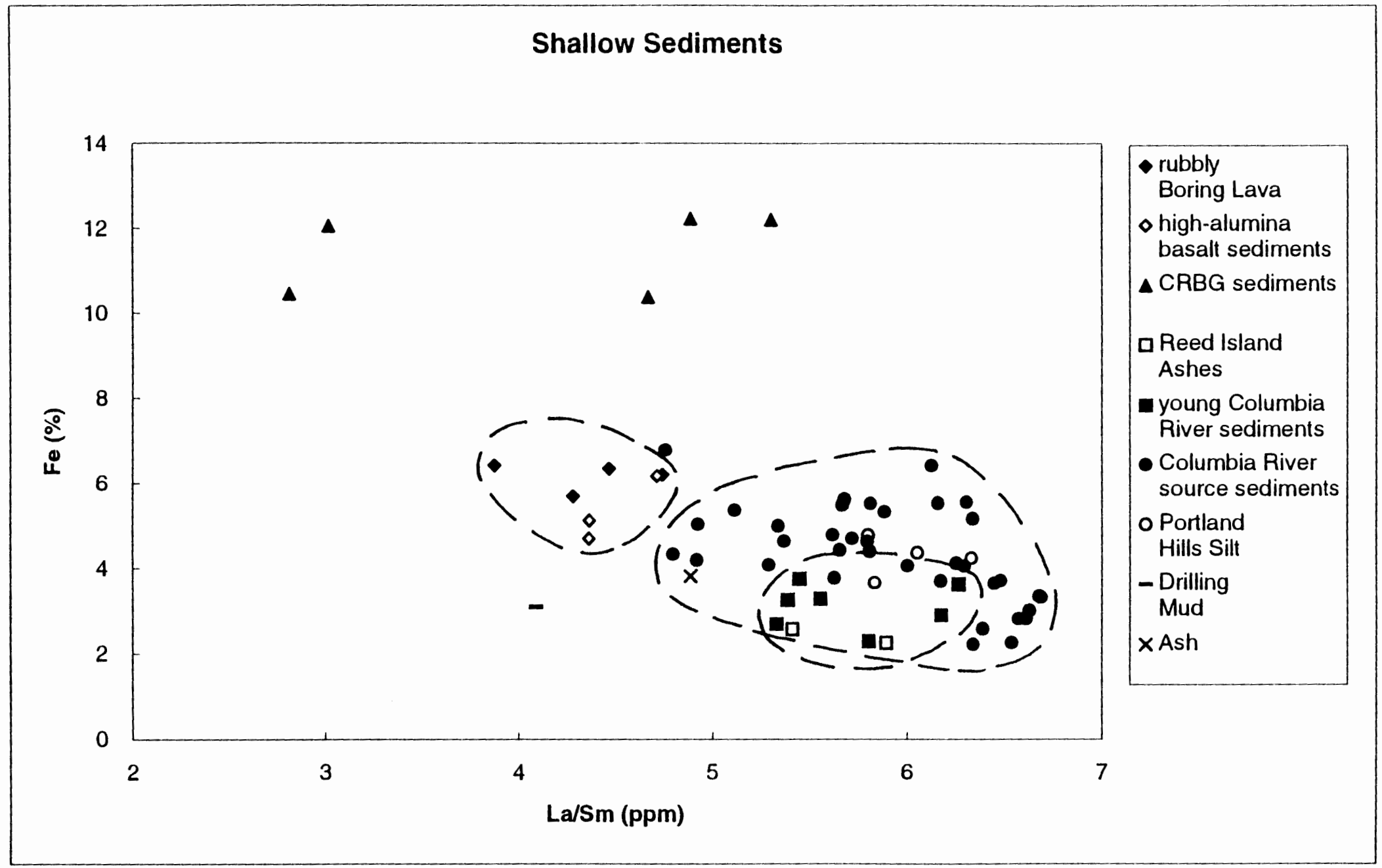

Figure 19. Shallow Sediments Scatter Plot (Lanthanum/Samarium vs. Iron). 


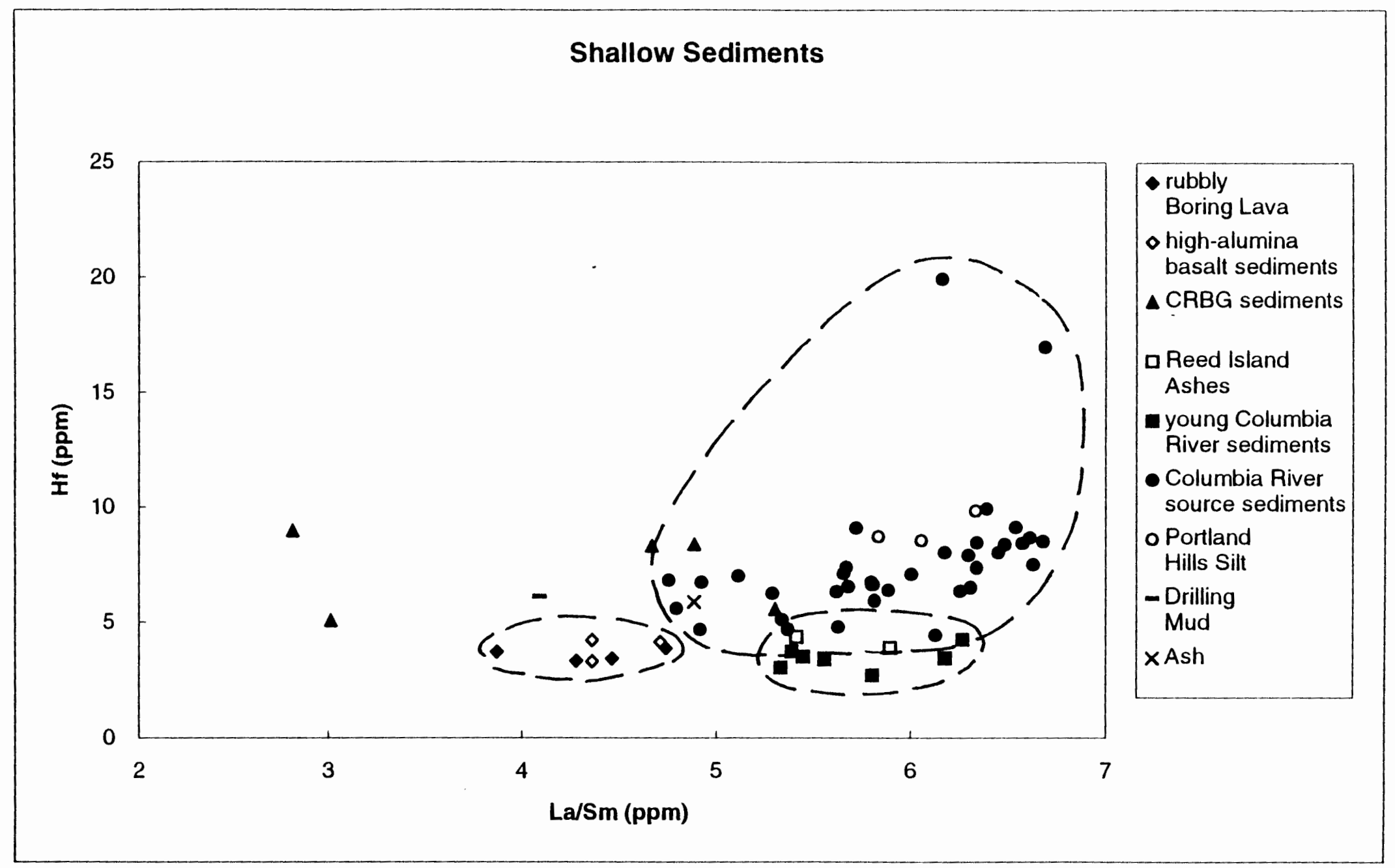

Figure 20. Shallow Sediments scatter Plot (Lanthanum/Samarium vs. Hafnium). 
hand sample examination and geographic location to establish five geochemical groups. Scatter plots of $\mathrm{Fe}$ vs. Hf and Hf vs. Th (Figures 15, 16, and 17) most clearly show these five groups, which are:

1. high-alumina basalt sediments,

2. CRBG sediments,

3. Reed Island ashes,

4. young Columbia River sediments,

5. Columbia River source sediments.

The above five geochemical groups were identified by comparing the geochemistry of the shallow and miscellaneous sediment samples, to the geochemistry of the following samples: (1) the three known sediment samples of Sandy River Mudstone, Portland Hills Silt, and Missoula Flood sediments, (2) the CRBG standard analyzed with each irradiation, and (3) the four rubbly Boring Lava samples previously identified in Squier Associates (1992) as Sandy River Mudstone Equivalent.

\section{High-Alumina Basalt Sediments}

During the initial investigation of the Boring Lava along the tunnel alignment by a Portland State University Advanced Geochemistry class (PSU, 1993), four samples of Trimet dril1 core (b557-211, b557-213, b561-135, and b561172) were collected from material identified as sandy River Mudstone Equivalent by Squier Associates (1992). 
Both hand sample examination and INAA showed that four samples collected as Sandy River Mudstone Equivalent, were primarily rubbly, scoriacious Boring Lava, with minor micaceous silts worked in. On scatter plots, the four samples consistently plotted together (Figure 15-20). These four rubbly Boring Lava samples aided in the identification of three samples collected from three shallow DOGAMI drill holes (VND1-25-30, GSD2-10-15, and GSD5-75-95) as having a similar geochemistry. Figure 4 presents the location of the DOGAMI drills holes in the Portland and Tualatin basins.

The three DOGAMI samples consistently plot near the four rubbly Boring Lava samples (Figures 15-20). Visual inspection of the three DOGAMI samples showed volcanic sands. A chondrite plot of these three volcanic sand samples with three non-volcanic sediment samples collected from the Trimet drill core show a slight difference in the slopes of the Iines from $\mathrm{Nd}$ to $\mathrm{Eu}$ (Figure 21). The non volcanic sediment samples show steep, straight, negative slopes from Nd to Eu, whereas the volcanic sand samples show a decrease in the slope angle from Sm to Eu. While one of these three samples is located near a Boring Lava source (Mt. Scott), the other two samples are not. According to Tolan and Beeson (1984), The Boring Lava and High Cascade volcanics are "... chemically, 


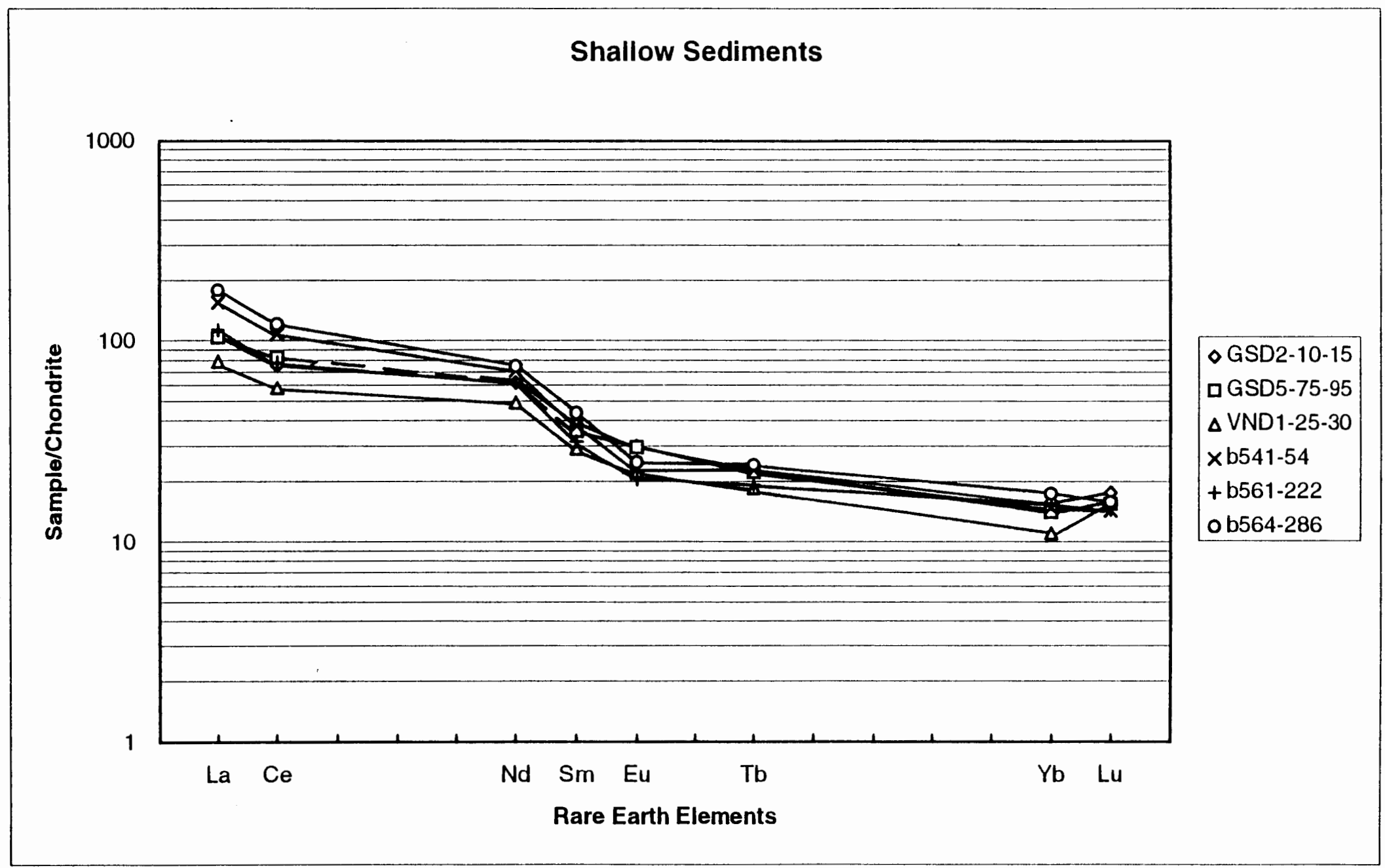

Figure 21. Shallow sediments Chondrite Plot (High-Alumina Basalt Sediments). 
lithilogically, and temporally similar." The similarity in geochemistry and the position of the other two DOGAMI sediment samples near rivers carrying Cascadian materials indicates a High Cascadian type of sediment. Tolan and Beeson (1984) used the term "high-alumina basalts" to describe both the Boring Lava and the High Cascade volcanics, as major oxide analyses indicated that both units are high-alumina basalts. On this basis, the term "high-alumina basalt sediments" is the name chosen to describe these three shallow DOGAMI sediment samples.

\section{CRBG Sediments}

This group of sediments was identified by using the CRBG standard analyzed in each irradiation. Five samples (b563-172.2, b563-212, b563-259, B565-226, and BVD4-36.5)

consistently plot near the CRBG standard. Figures 3 and 4 show these sample locations. Additionally, all five samples were collected from layers overlying solid CRBG rock. Higher concentrations of $\mathrm{Fe}, \mathrm{Co}, \mathrm{Zn}, \mathrm{Eu}$, and $\mathrm{Hf}$ typically characterize these sediments. Unique patterns on the chondrite plots also distinguish the CRBG sediments from the overlying sediments (Figures 22 and 23). Figure 22 presents the chondrite plot for all samples collected from Trimet drill hole B563. Figure 23 presents the chondrite plot for all samples collected from Trimet drill hole B565. Both the CRBG sediments and non volcanic 


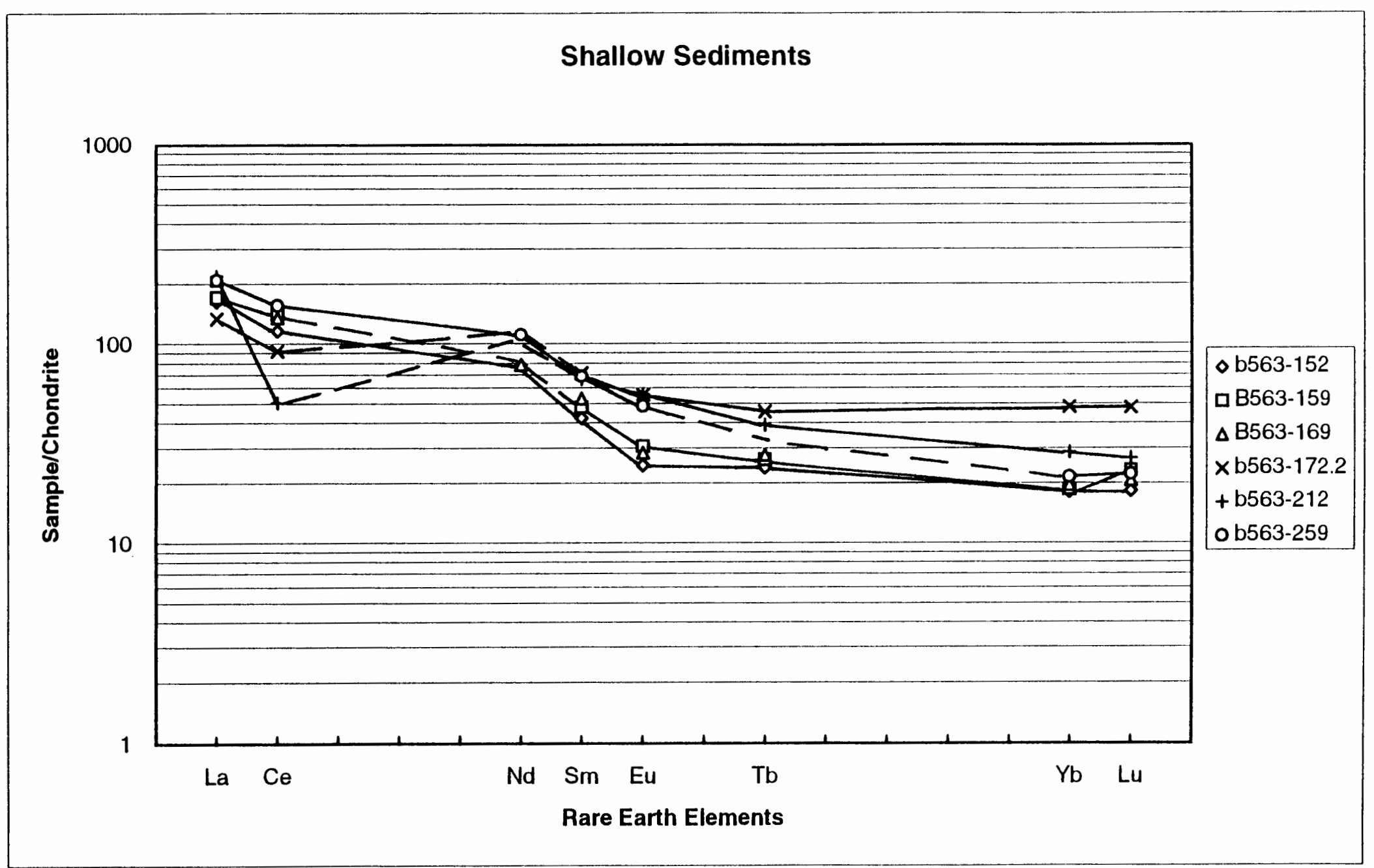

Figure 22. Shallow sediments Chondrite Plot (Samples from Trimet Drill Hole B563). 


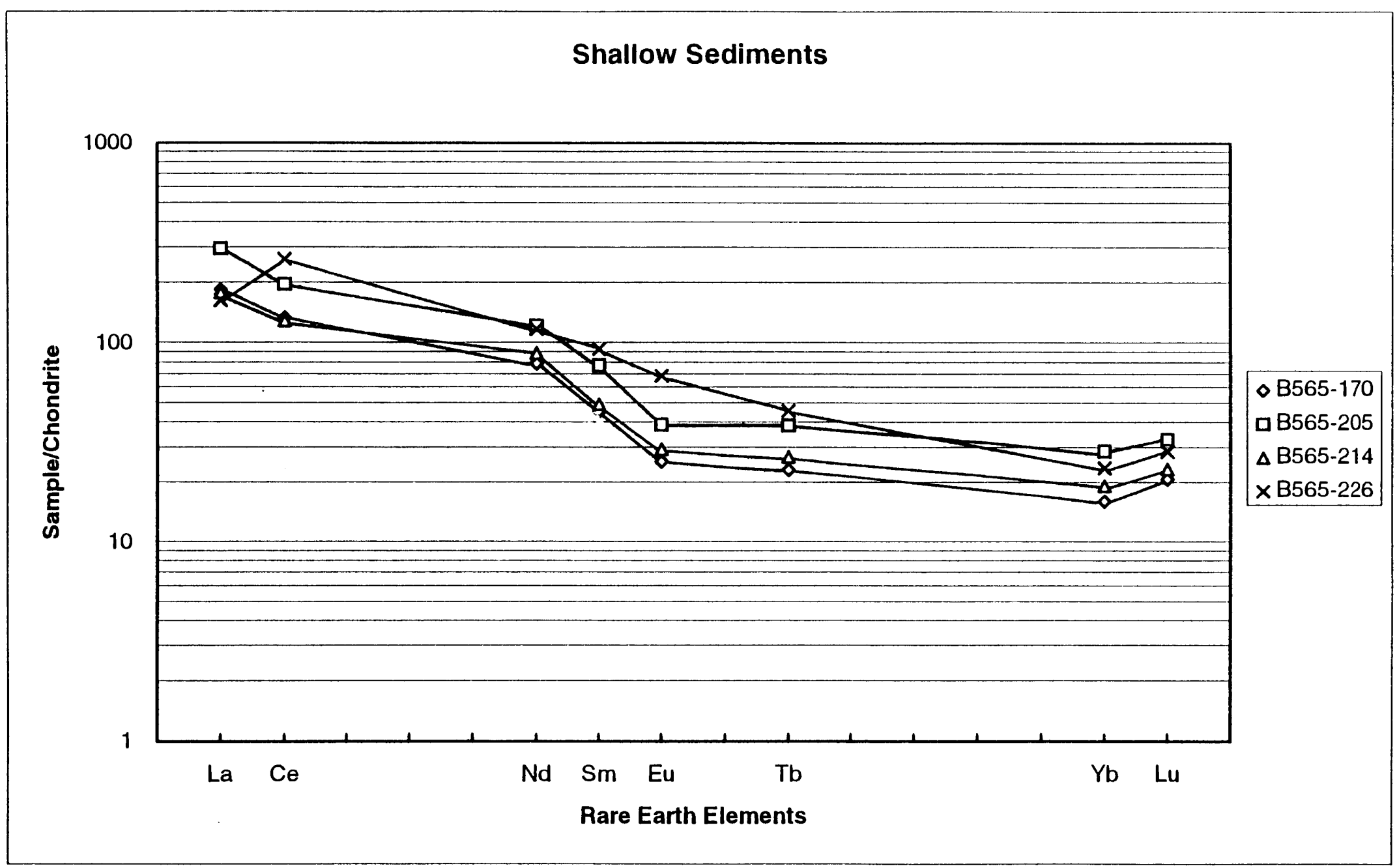

Figure 23. Shallow Sediments Chondrite Plot (Samples from Trimet Drill Hole B565). 
sediment samples collected from each hole are included on the chondrite plots. In both plots, the non volcanic sediment samples show steep, straight, negative slopes from $\mathrm{Nd}$ to $\mathrm{Eu}$, and an almost zero slope from Eu to $\mathrm{Tb}$. The CRBG sediments show a more gentle, negative slope from Nd all the way to $\mathrm{Tb}$.

The CRBG sediments are easily distinguished from the rubbly Boring Lava and high-alumina basalt sediments. The rubbly Boring Lava and high-alumina basalt sediments have overall lower element concentrations than do the CRBG sediments.

\section{Reed Island Ashes}

Two samples of volcanic ash (SR-3-JS and Sample \#7) were collected on Reed Island in the Columbia River east of the Sandy River Delta (Figure 8). Though these samples were collected for a separate project under Dr. Curt Peterson, they were irradiated and analyzed as part of this study due to their location in the Columbia River.

Visual inspection showed light-weight, powdery, ashy material. One sample is noted to be an impure ash sample in the notes taken by the sample collector (John Siskowic). The two volcanic ash samples have similar patterns on the chondrite plots, showing a negative slope from Nd to $\mathrm{Tb}$ (Figure 24). Another volcanic ash sample and three non-volcanic sediment samples are also shown in 


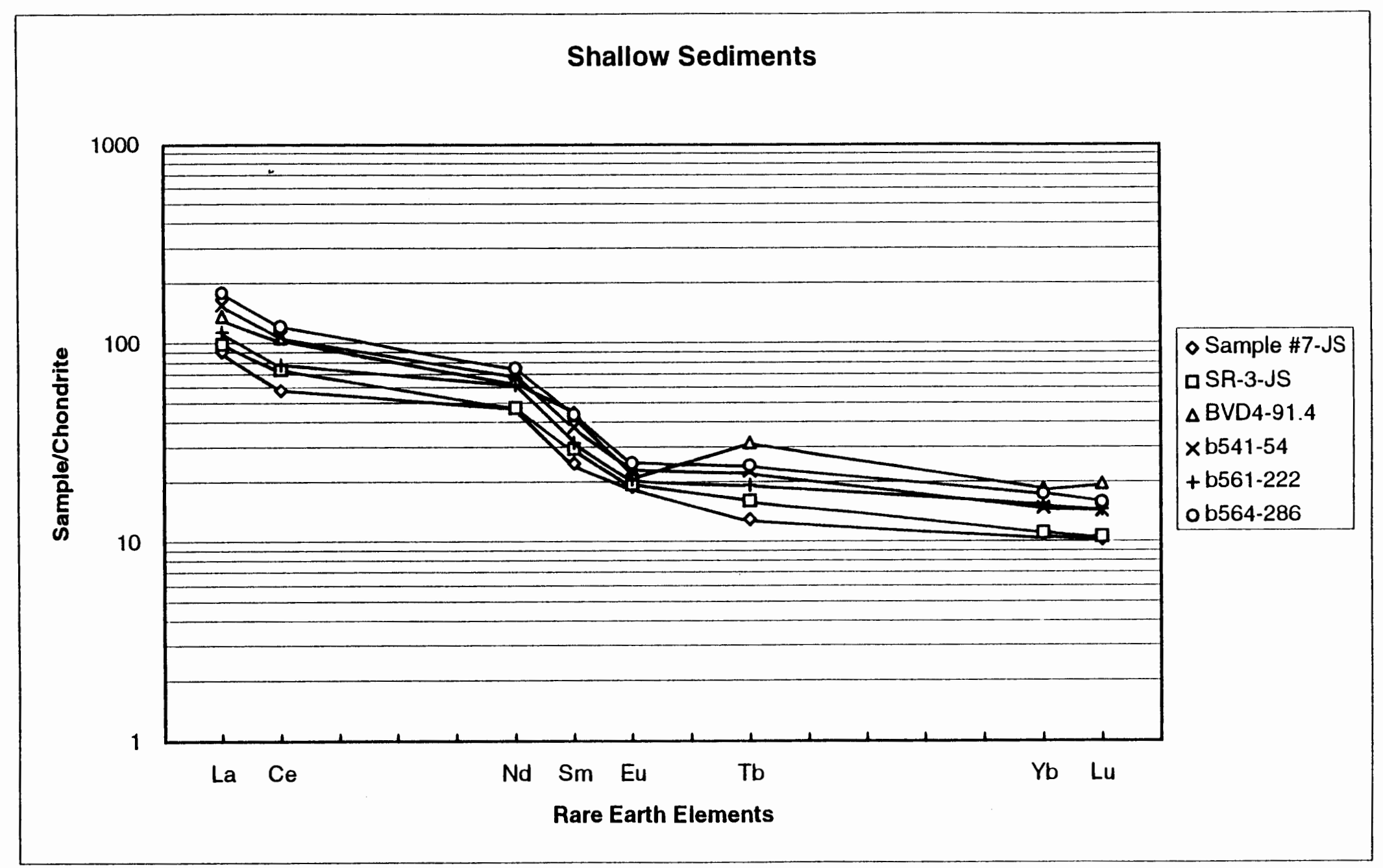

Figure 24. Shallow Sediments Chondrite Plot (Reed Island Ashes and BVD4-91.4 Sample). 
Figure 24. On scatter plots, the two volcanic ash samples tend to plot together (Figures 15-20). The location of the Reed Island ash samples in the Columbia River and their shallow depth (exposed in outcrop on Reed Island during the summer) indicate that these ashes are likely to be local, relatively recent Cascadian ashes. In addition, they consistently plot away from all sediment groups except the young Columbia River sediments (to be discussed in the next section). The Reed Island ashes do not compare with other volcanic ash samples analyzed for this study.

\section{Young Columbia River sediments}

This group is identified primarily using scatter plots. On all but a few plots, six of seven samples (MTD1-30-40, MTD1-50-55, MTD1-105-110, MTD1-155-165, MTD1225, and MTD2-145-155) plot together in a tight group. The chondrite plot of these samples shows very similar negative slopes from $\mathrm{Nd}$ to $\mathrm{Tb}$ (Figure 25). These samples also typically have coarse sand to granule size gravel grains including large mica flakes and numerous lithic grains (basalt, quartzite, granite, and andesite). Sample ORD1-19.6 (Figure 4) is a light brown, micaceous sand containing some coarse, black gravelly grains of basalt. It doesn't visually appear to be the same as the above samples and it tends to wander on the scatter plots. The 


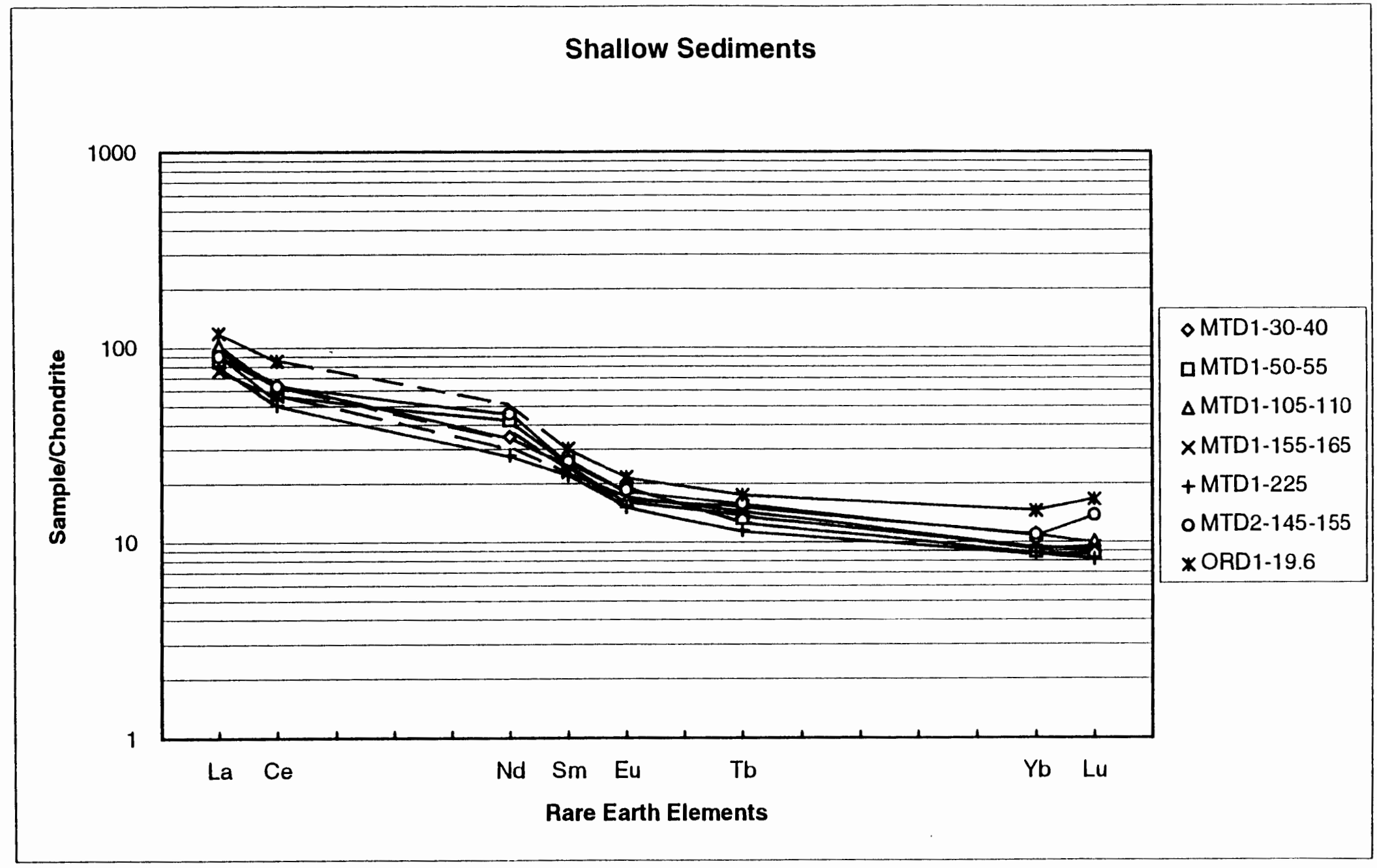

Eigure 25. Shallow Sediments Chondrite plot (Young Columbia River Sediments). 
slope of the line for this sample on the chondrite plot compares closely with the above six samples (Figure 25). Thus, it is included in the young Columbia River sediment group.

The geographic location (very near the Columbia River) and stratigraphic position (upper 250 feet of MTD1) of the young Columbia River sediments samples suggest that they represent relatively recent Columbia River channel materials. The position of this group on the scatter plots (Figures 15-20) compares well with the positions of the high-alumina basalt sediments and the rubbly Boring Lava on scatter plots. In particular, on Figures 16 and 17, the young Columbia River sediments and the highalumina basalt sediments plot in one tight group that does not significantly overlap with the Columbia River source sediments (to be discussed in the next section). This indicates the young Columbia River sediments contain a significant component of younger Cascadian-type materials.

\section{Columbia River Source Sediments}

This group is a large and broad representation of the sediments deposited by the Columbia River (Sandy River Mudstone and Missoula Flood deposits), or wind-blown sediment from the Columbia River source area (i.e. the Portland Hills silt). Though each sediment type may have been deposited under different conditions, they all came 
from the same general source area; thus their geochemistry is quite similar. None of the samples analyzed in this group were identified on DOGAMI boring logs as Troutdale Formation sediments.

Portland Hills Silt samples are identified only because of sampling location and positive identification of hand samples. The scatter of the four Portland Hills Silt data points within the Columbia River source sediment group shows that they appear to be indistinguishable from the other samples of the Columbia River source sediment group (Figures 15-20).

The chondrite plots of the Columbia River source sediment group show steep, negative slopes from $\mathrm{Nd}$ to Eu, then a zero or slightly positive slope from Eu to $\mathrm{Tb}$ (Figures 26 and 27). When Columbia River source sediment chondrite plots are compared with volcanic chondrite plots (either CRBG sediments, or high-alumina basalt sediments), the difference in slopes between the groups (sedimentary vs. volcanic) is clearly visible (Figures 21-23).

Two other samples within the Columbia River source sediment should be discussed. First is a sample of preCRBG sediment collected from 330 feet of depth in the David Hill Well (DHW-330), located on the western edge of the Tualatin basin (Figure 7). This sample is presumed to have been deposited by the Columbia River prior to the 


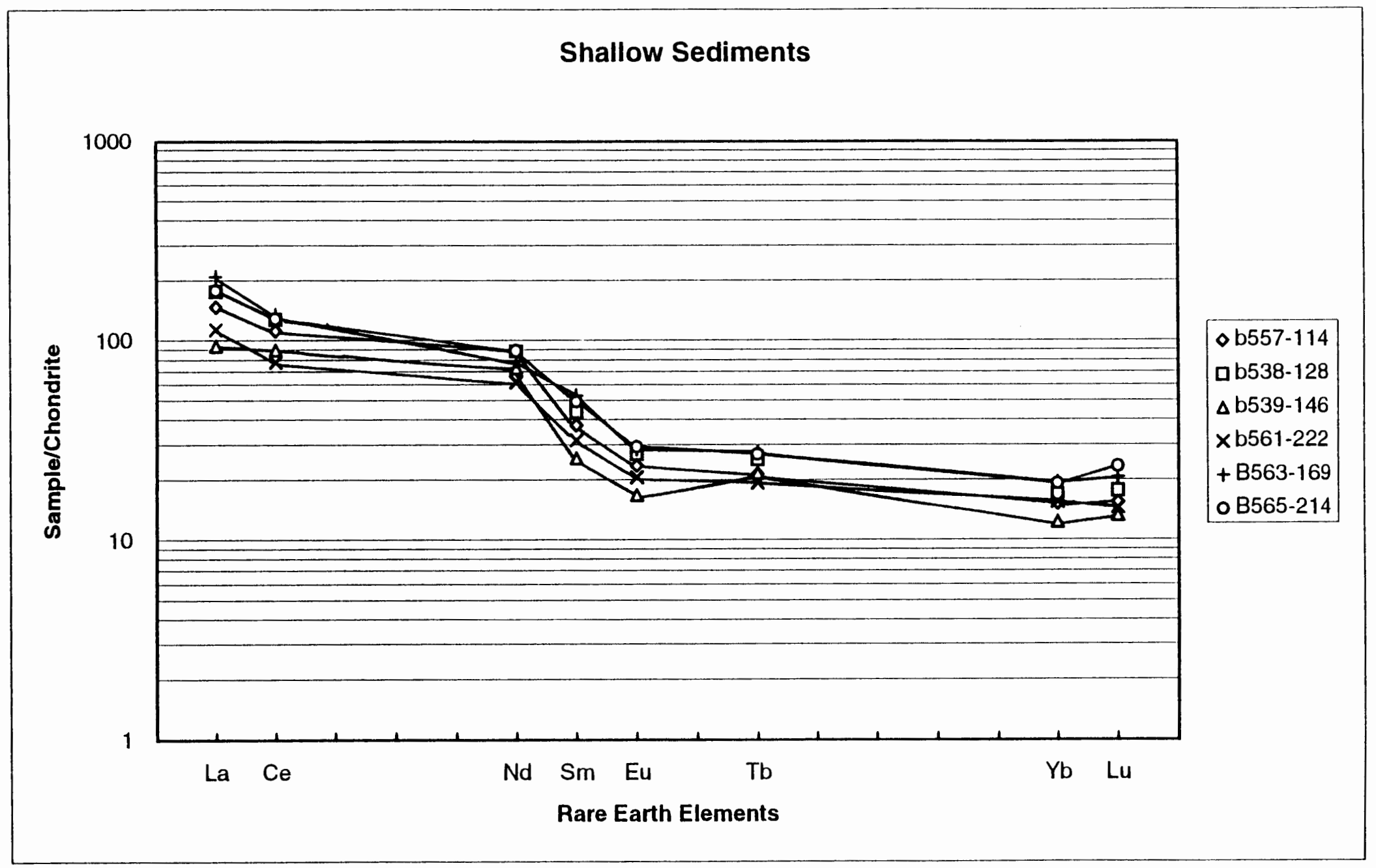

Figure 26. Shallow Sediments Chondrite Plot (Columbia River Source Sediments). 


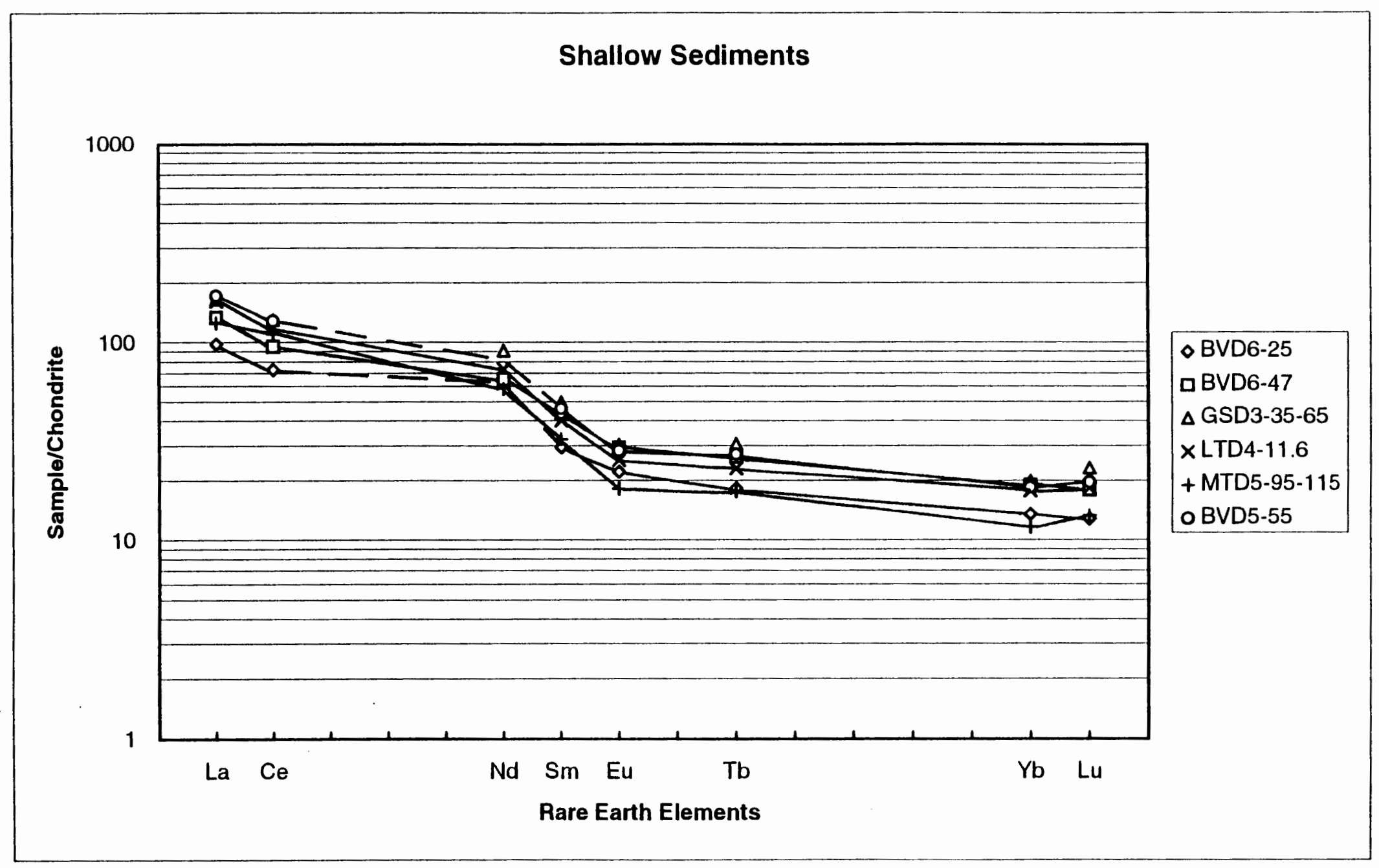

Figure 27. Shallow Sediments Chondrite plot (Columbia River Source Sediments). 
deposition of the CRBG. Consequently, this sample plots with the other Columbia River source sediment samples, and no separate symbol denotes it on the scatter plots.

second, a thin layer of volcanic ash is identified in BVD4 at 91.4 feet of depth (Figure 4). In hand sample, it is a white, fine-grained, and light-weight material. Though it tends to plot with the Columbia River source sediment group (marked with an $X$ on scatter plots, Figures 15-20), its chondrite plot is noticeably different from the other sediments (Figure 24). A steep, negative slope from $\mathrm{Nd}$ to $\mathrm{Eu}$ is shown for all of the plotted samples. However, the volcanic ash sample has a positive slope from Eu to $\mathrm{Tb}$, whereas the sediments have zero or continued negative slopes.

\section{PORTLAND INTERNATIONAL AIRPORT DRILI HOLE}

The sediment samples collected from the Portland International Airport Drill Hole (MTD1, 1523 feet) represent the materials transported by the Columbia River, into the Portland basin, during and after the eruption and emplacement of the CRBG. Sample geochemistry was compared with hand sample examination to establish geochemical groups. The large amount of volcanic material in many samples made the separation of geochemical units unexpectedly straightforward. Three units are identified 
and shown on scatter plots of Hf vs. Cr and Hf vs. Th (Figures 28 and 29):

1. Young Columbia River sediments,

2. episodic Cascadian volcanic sediments,

3. lower Troutdale Formation.

\section{Young Columbia River sediments}

The arguments for the distinction of the young Columbia River sediment are the same as those presented in the previous section discussing the shallow sediment and miscellaneous samples. One additional sample from the Portland basin sediments is added to the young Columbia River sediment group. MTD1-295-300 was not included in the shallow sediment and miscellaneous sample data set as its depth was greater than 250 feet. However, it does fall neatly into the young Columbia River sediment group on the scatter plots, and has a chondrite plot very similar to the other samples included in that unit.

\section{Episodic Cascadian Volcanic Sediments}

This group consists of all samples located between 400 and 800 feet, with the exception of one sample at 575 feet. This group was identified initially by the hand samples, all of which are primarily dark in color. Some samples may even display primary volcanic features and 


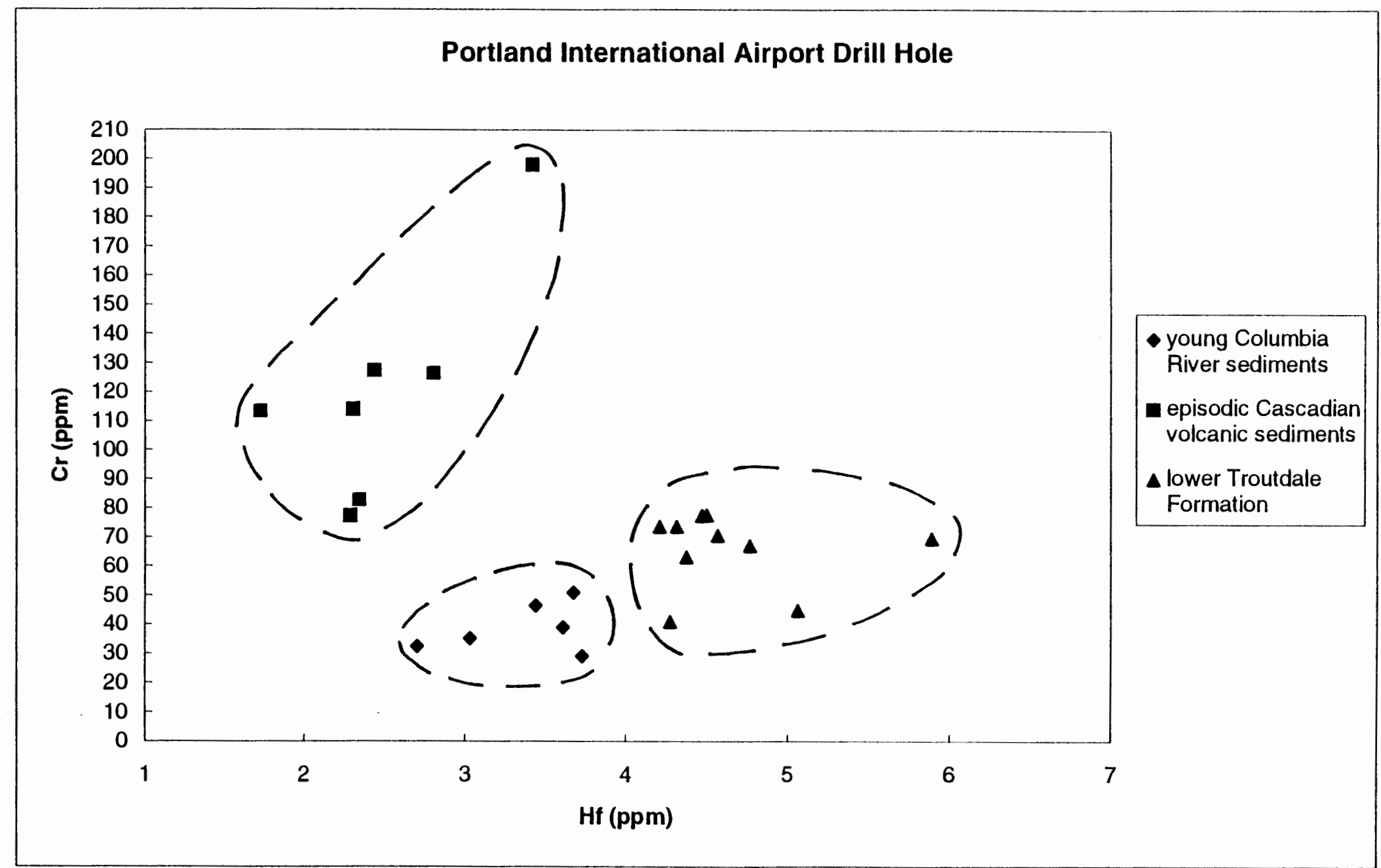

Figure 28. Portland International Airport Drill Hole Scatter Plot (Hafnium vs. Chromium). 


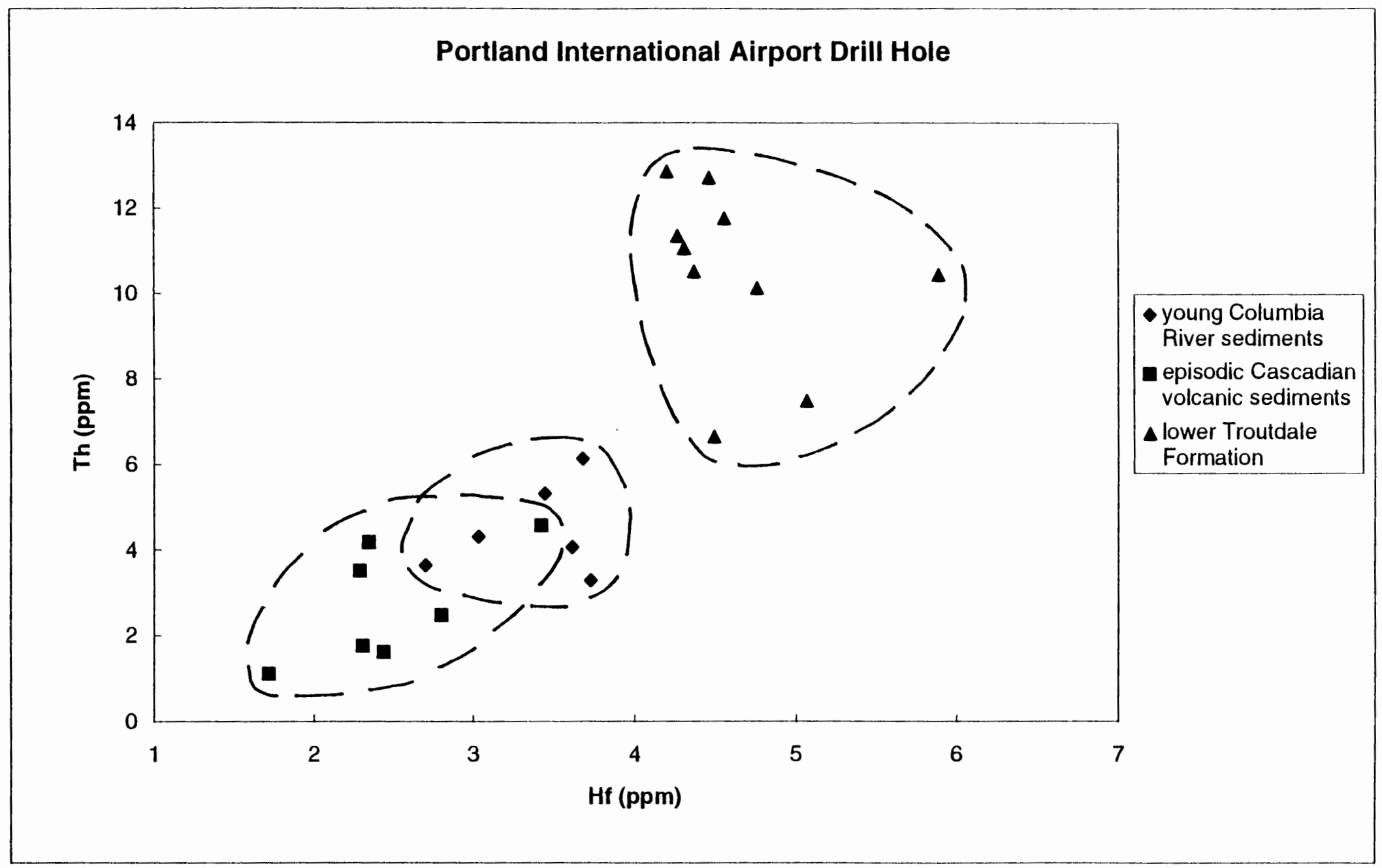

Figure 29. Portland International Airport Drill Hole Scatter Plot (Hafnium vs. Thorium). 
textures. The scatter plots confirmed what was visible in the hand samples. The chondrite plots also show that these samples are geochemically similar (Figure 30). Positive slopes from $\mathrm{Ce}$ to $\mathrm{Nd}$, negative slopes from $\mathrm{Nd}$ to $\mathrm{Sm}$, and zero slopes from $\mathrm{Sm}$ to Eu all help to define this particular unit.

The choice of name for this group was based on depth, proximity to the Cascades, and the presence of a nonvolcanic sediment layer at 575 feet, indicating at least two episodes in the depositional history. In addition, its geochemistry does not compare with the high-alumina basalt sediments or the CRBG sediments on scatter plots (see Figures 33-35).

\section{Lower Troutdale Formation}

This group includes primarily the deeper samples collected from MTD1. The samples from 800 feet of depth and below are considered to be part of the lower Troutdale Formation. Two shallow samples (350-358 feet and 575 feet) are also included in this group, as they generally plot with the other deeper samples on both the scatter and chondrite plots (Figures 28 and 29, and Figures 31 and 32, respectively). This group is identified as the lower Troutdale Formation based on, hand sample inspection, geographic and stratigraphic position, and the description of the lower Troutdale Formation as presented by Tolan and 


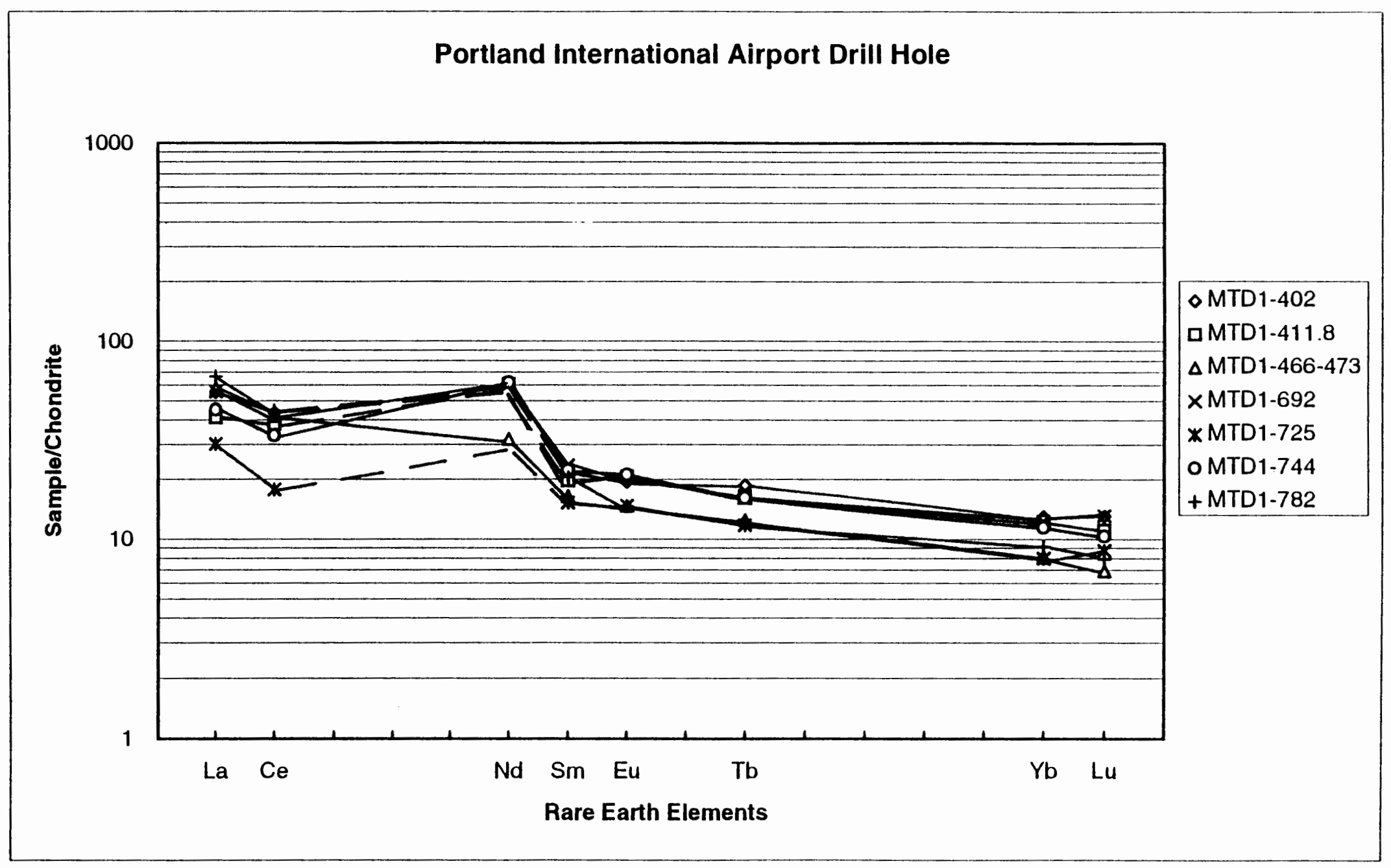

Figure 30. Portland International Airport Drill Hole Chondrite Plot (Episodic Cascadian Volcanic Sediments). 


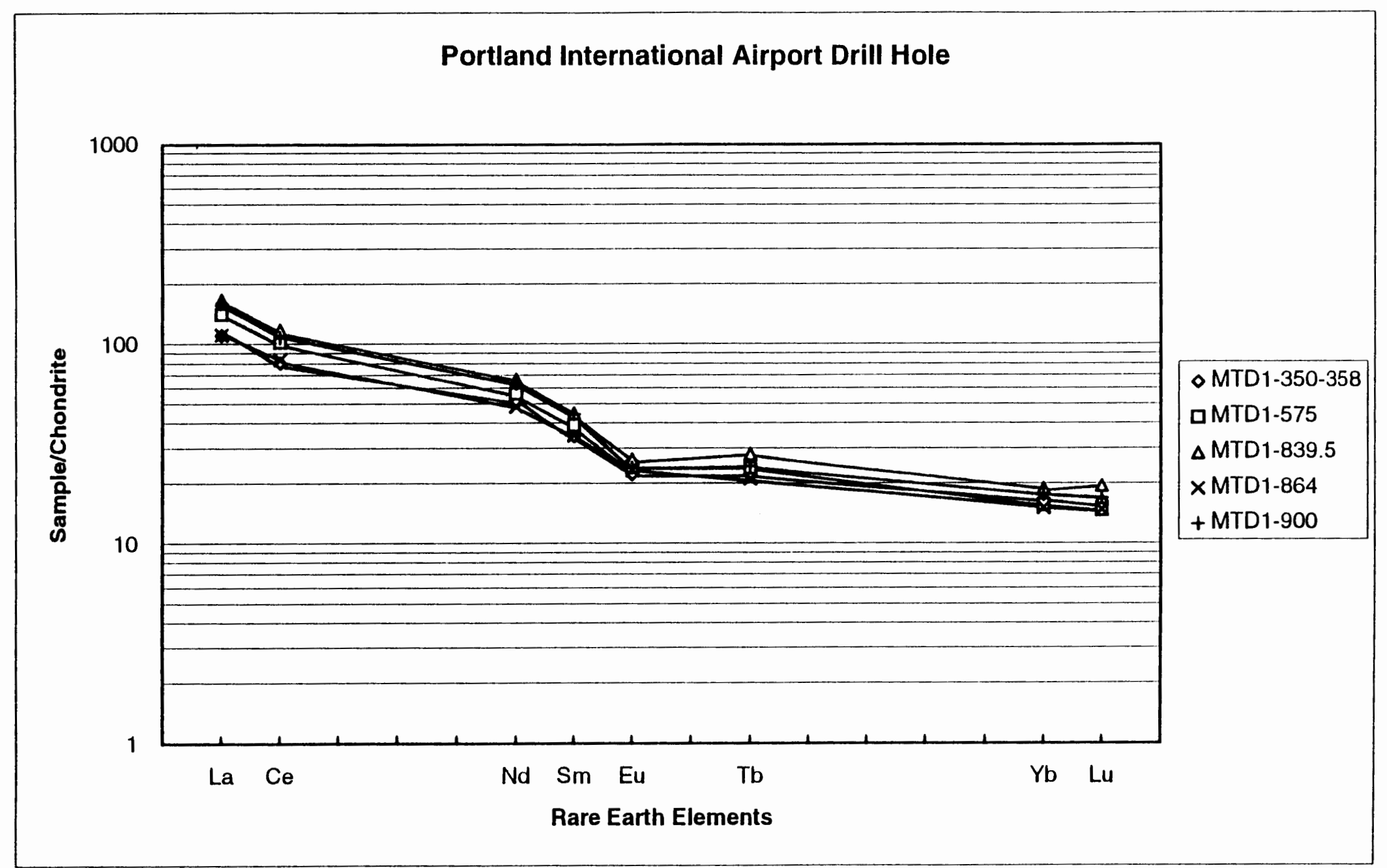

Figure 31. Portland International Airport Drill Hole Chondrite Plot (Lower Troutdale Formation). 


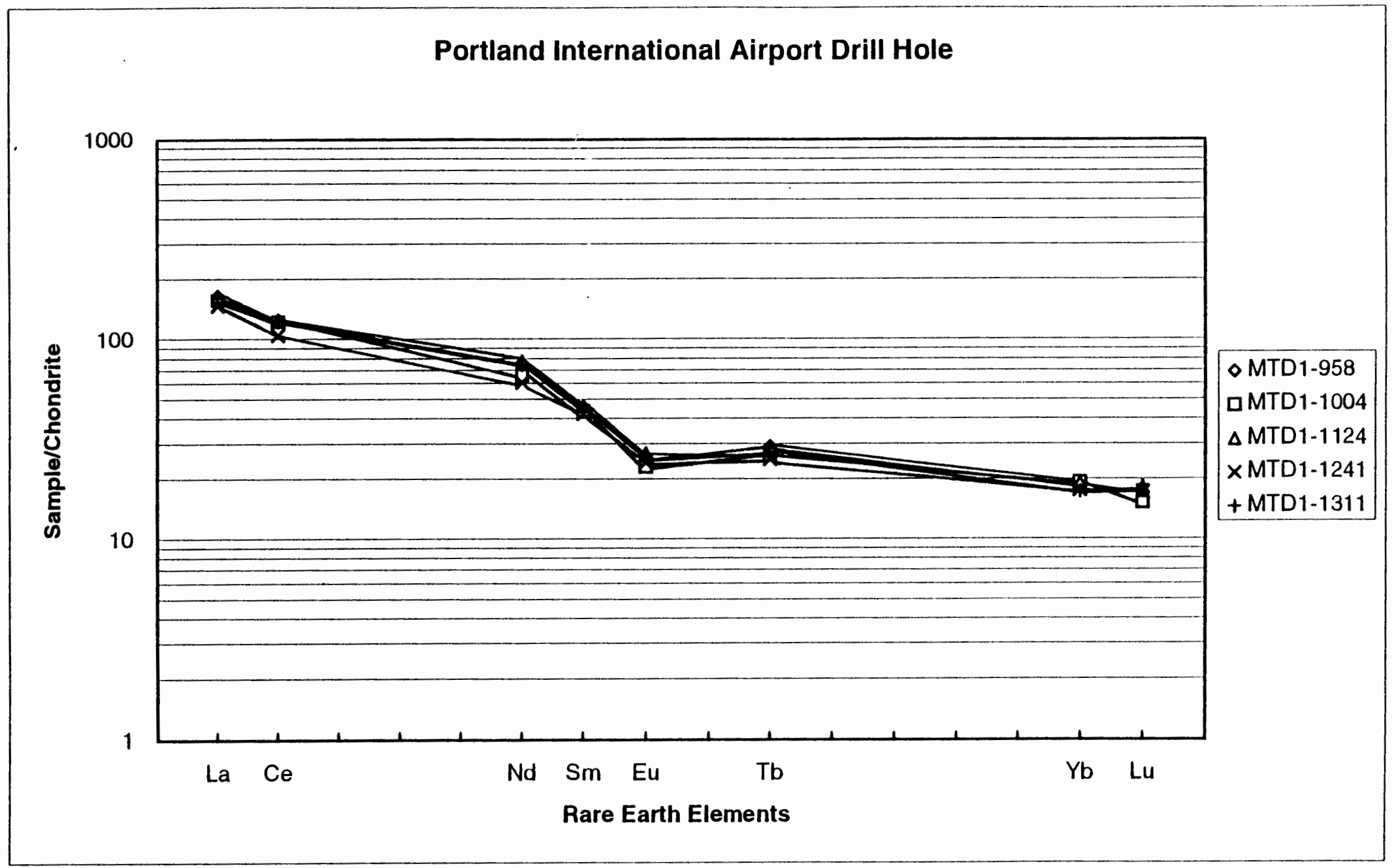

Figure 32. Portland International Airport Drill Hole Chondrite Plot (Lower Troutdale Formation). 
Beeson (1984): "...quartzite-bearing, basaltic conglomerates and micaceous arkosic sandstones." Scatter plots for the lower Troutdale Formation show that the samples generally fall within the range of the Columbia River source sediments group. However, on several plots, they seem to be concentrated in one area of the Columbia River source sediment group (Figures 33-35).

\section{HILLSBORO AIRPORT DEEP DRILL HOLE}

Sediment samples were collected from the Hillsboro Airport Drill Hole (HBD1, 1095 feet). The source(s) of these sediments is currently unknown. The potential contributors include the Columbia River (both normal depositional material and flood deposits), rivers having source areas in the Coast Range, the willamette River, and materials eroded from the nearby Tualatin Mountains, including the Boring Lava, CRBG, and loess.

Hand sample examination and geochemistry were unsuccessful in delineating distinct, consistent groups, with two exceptions. The first exception includes two samples collected from approximately 760 feet. They are lightweight, fine-grained, pale green ashy samples that do not visually compare with other samples collected from HBD1. They have a texture distinct from the other sediment samples, and contain no visible mica. Scatter 


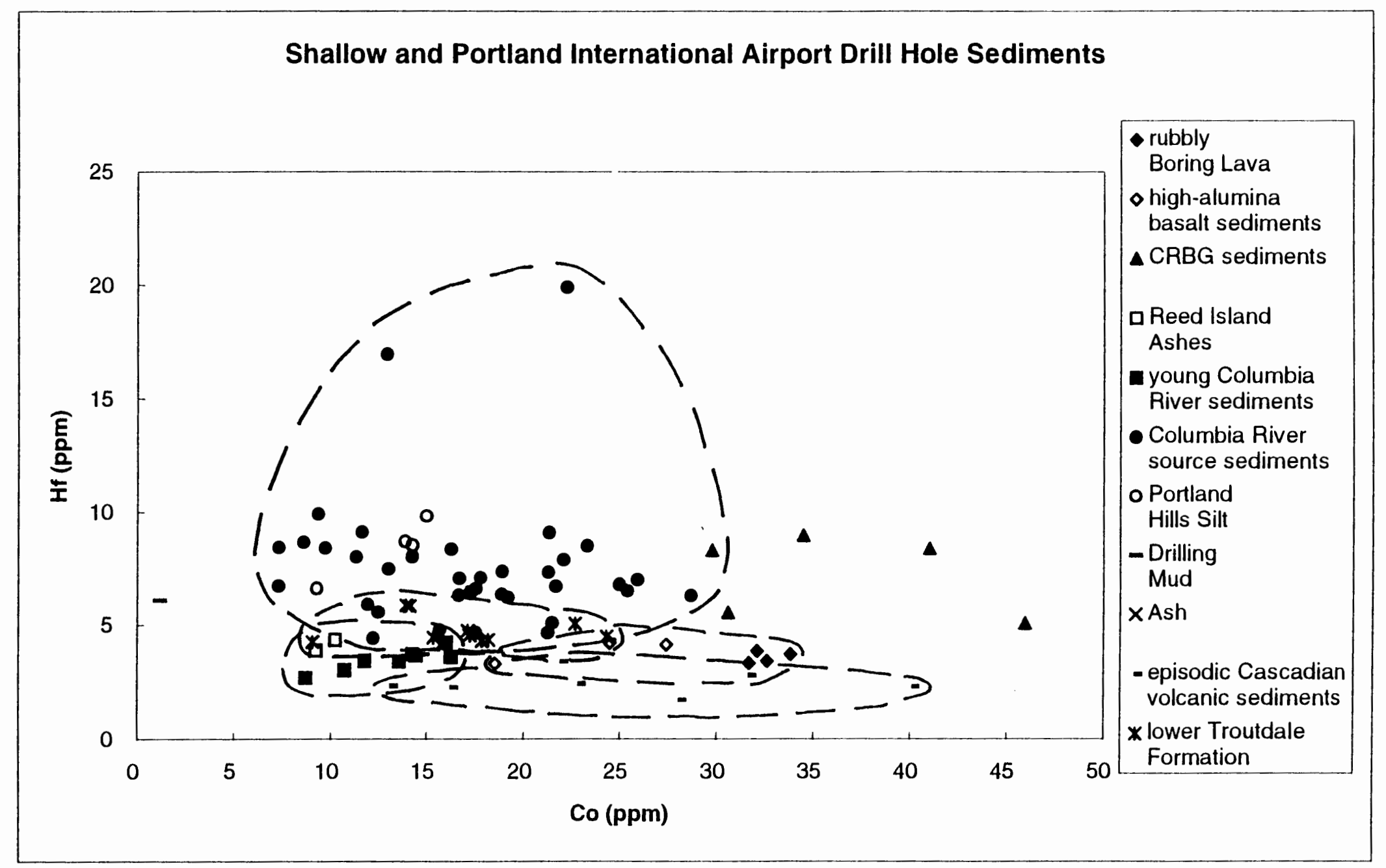

Figure 33. Shallow and Portland International Airport Drill Hole Sediments Scatter Plot (Cobalt vs. Hafnium). 


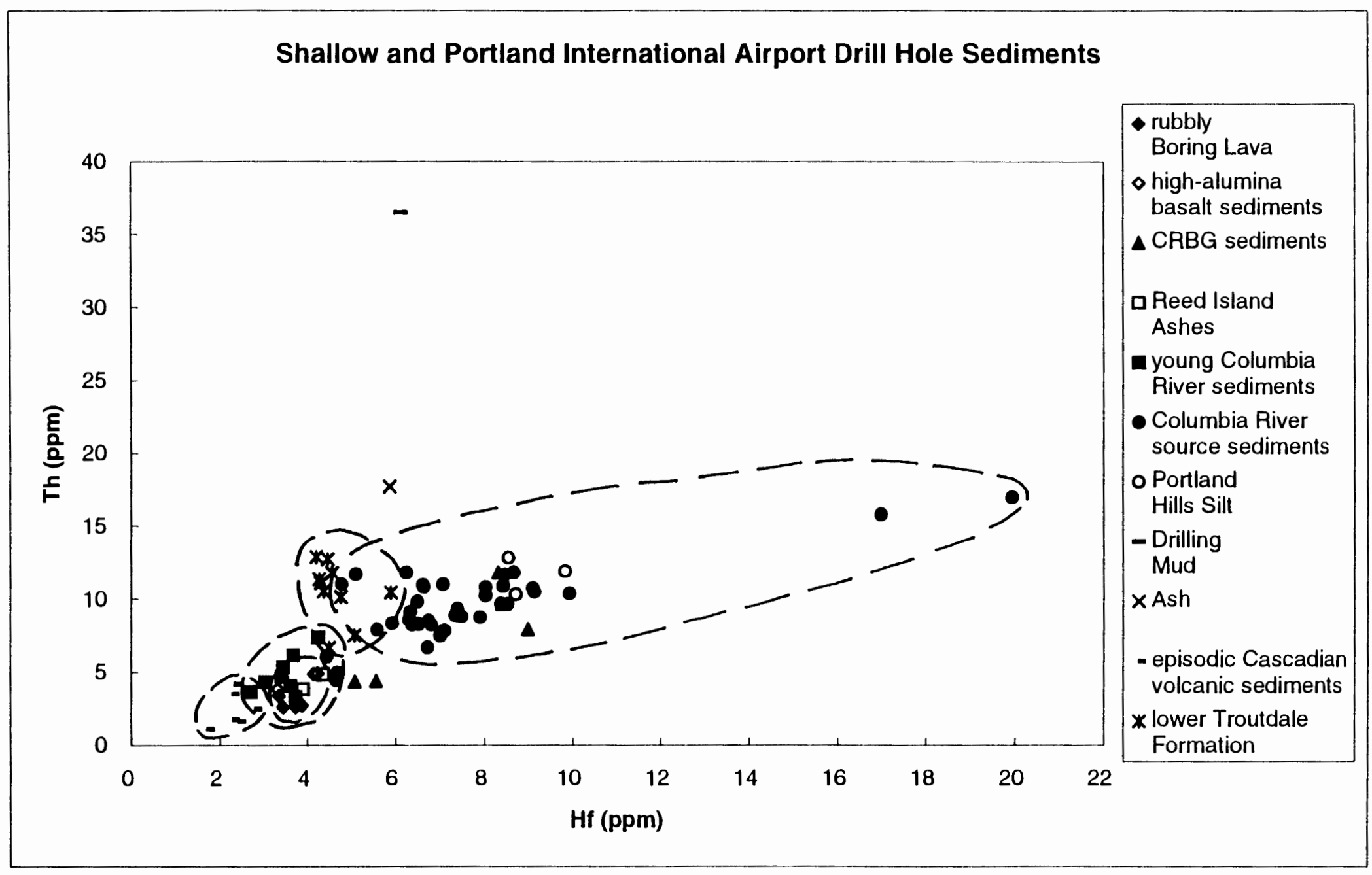

Figure 34. Shallow and Portland International Airport Drill Hole Sediments Scatter Plot (Hafnium vs. Thorium). 


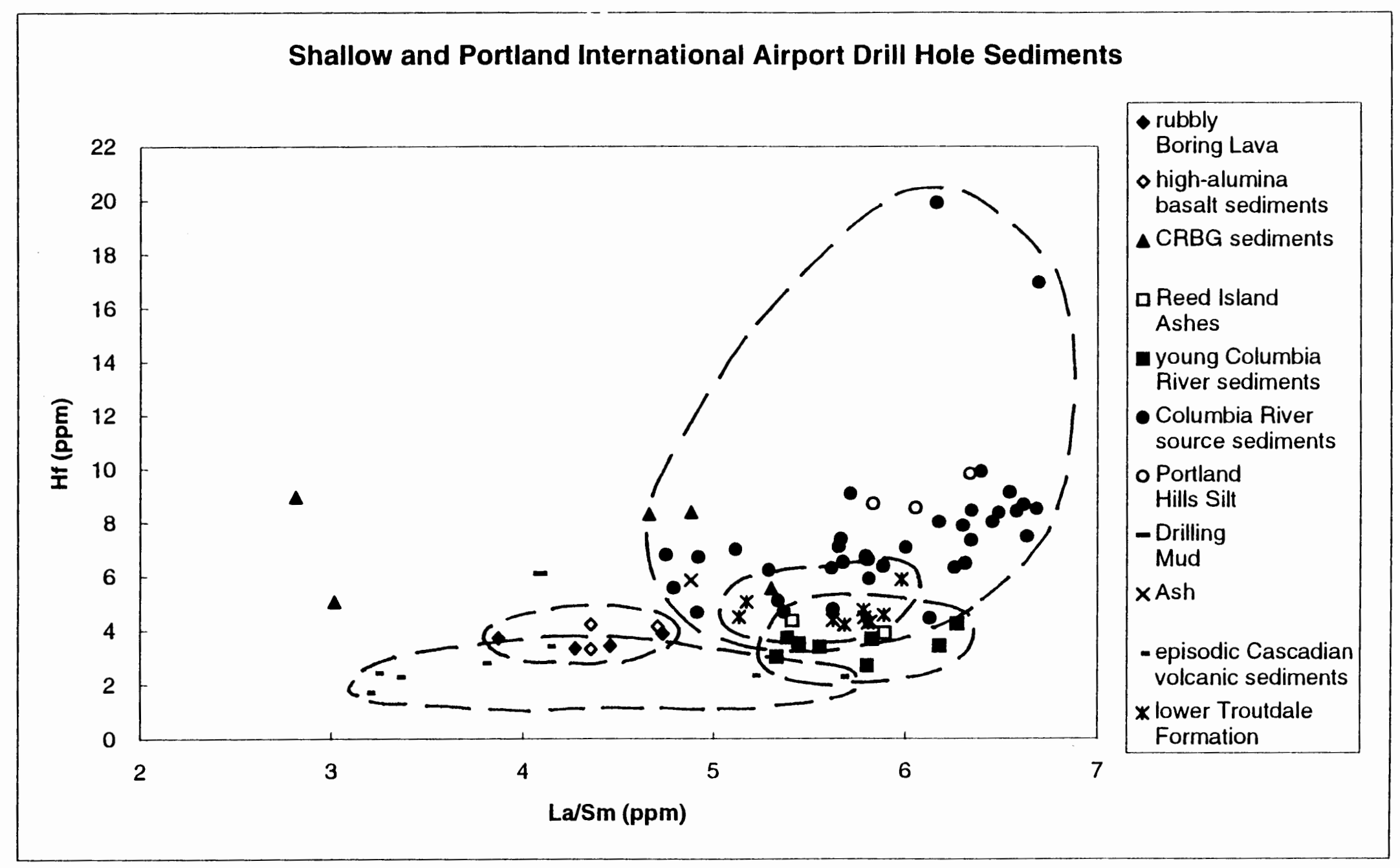

Figure 35. Shallow and Portland International Airport Drill Hole Sediments Scatter plot (Lanthanum/Samarium vs. Hafnium). 
plots show the geochemical differences between these two samples and the other samples from HBD1 (Figures 36 and 37). A chondrite plot also shows unique patterns for these two samples (Figure 38 ).

The second exception is that samples collected from near the sediment-CRBG contact plotted in widespread positions on the scatter plots in comparison to the majority of the other sediment samples. This widespread scatter is interpreted to indicate that weathering processes have begun to affect the sediments overlying the CRBG (Figures 36 and 37).

The remainder of the samples plotted in one large, broad group. No trends or consistent patterns could be determined from the geochemistry of the Tualatin basin sediments. Visual examination did not identify anything other than fine-grained, micaceous silts, clayey silts, or sandy silts. The samples also do not appear to have the same geochemistry as the Columbia River source sediments (Figures 39,40 , and 41).

These three scatter plots (Figure 39, 40, and 41) compare samples representing some of the key geochemical groups. On Figure 39, the Tualatin basin sediments from HBDl fall within nearly every geochemical group shown. On Figure 40, the Tualatin basin sediment samples from HBD1 fall within the Columbia River source sediment geochemical 


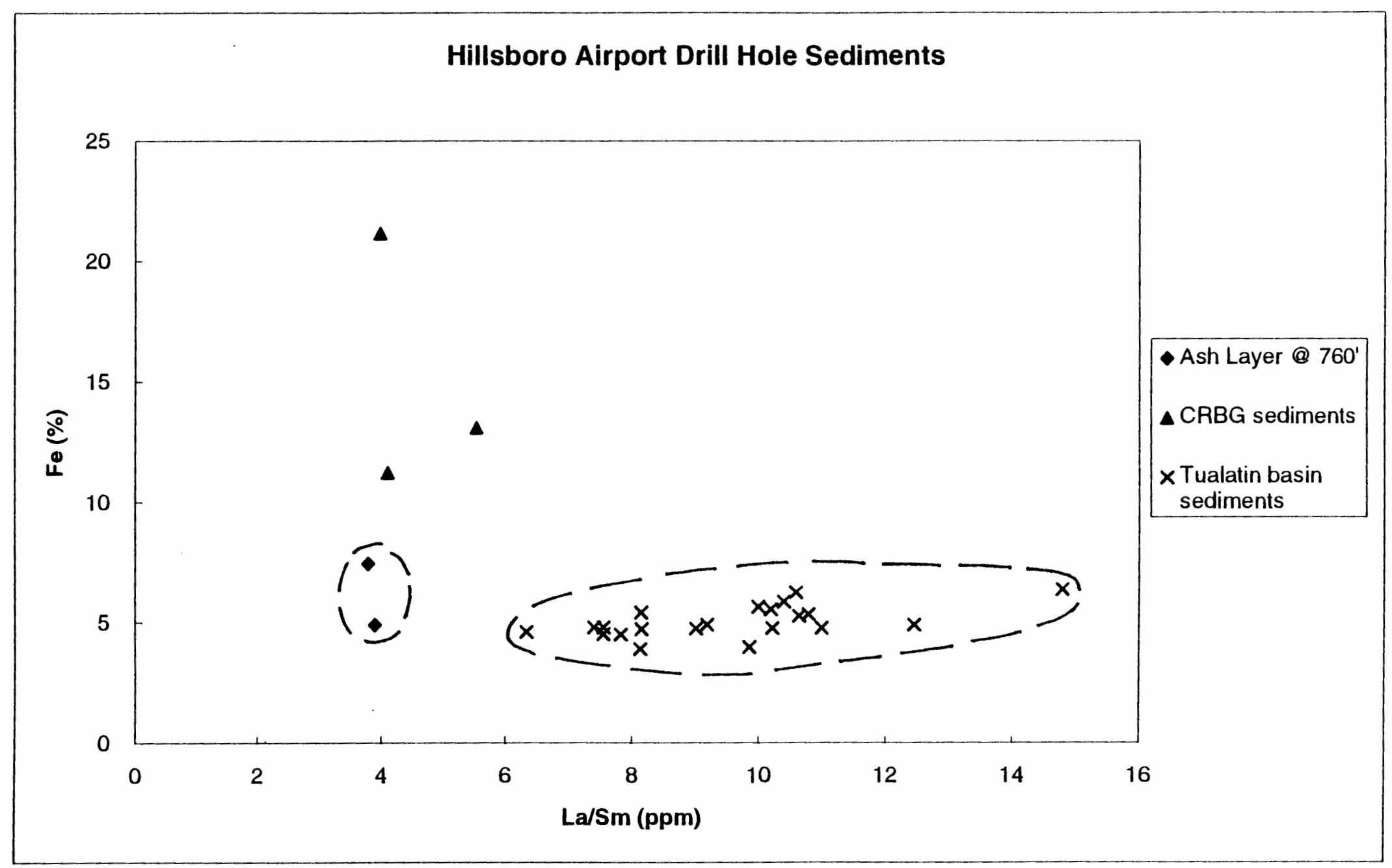

Figure 36. Hillsboro Airport Drill Hole sediments Scatter plot (Lanthanum/Samarium vs. Iron). 


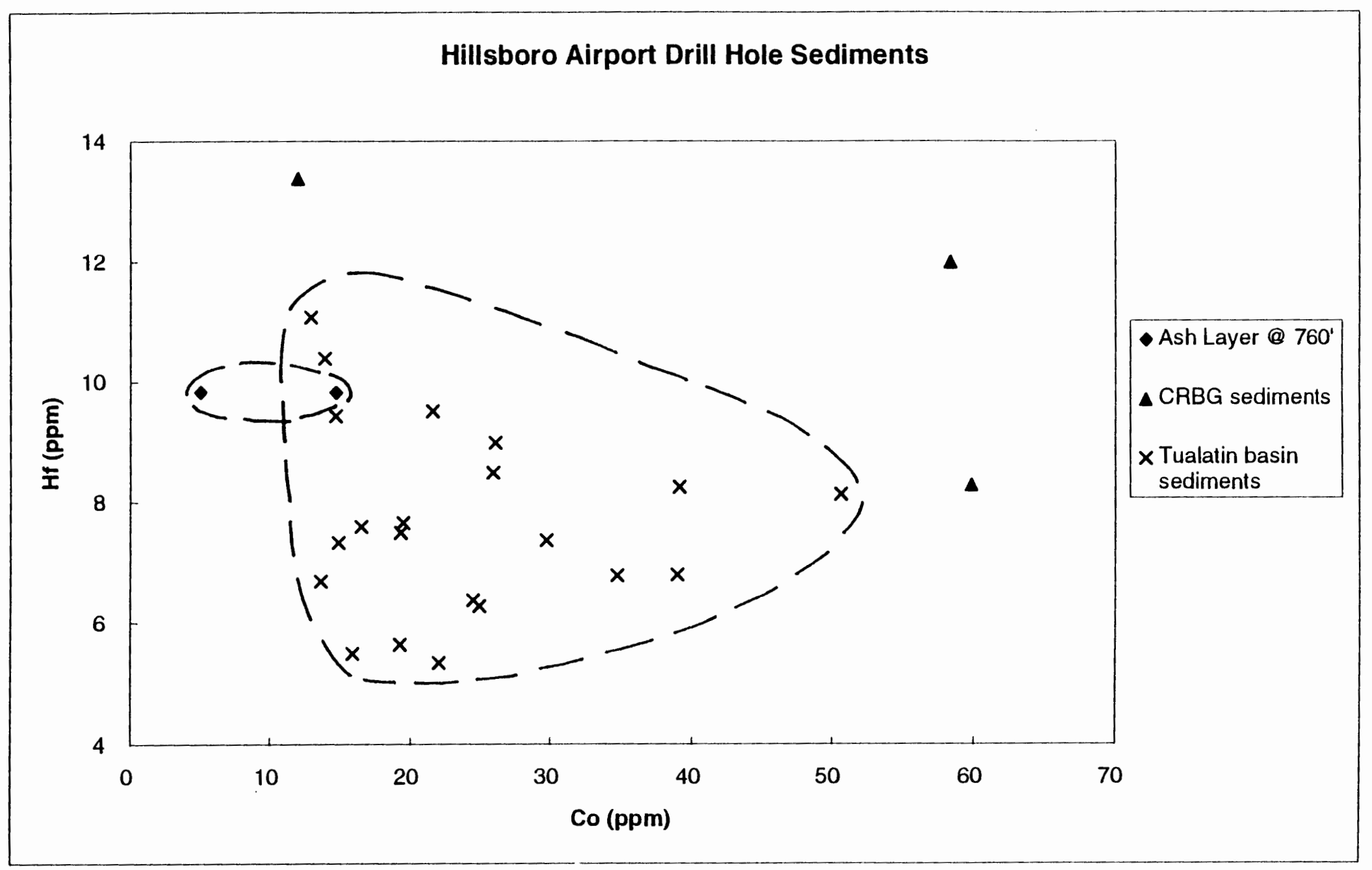

Figure 37. Hillsboro Airport Drill Hole sediments Scatter plot (Cobalt vs. Hafnium). 


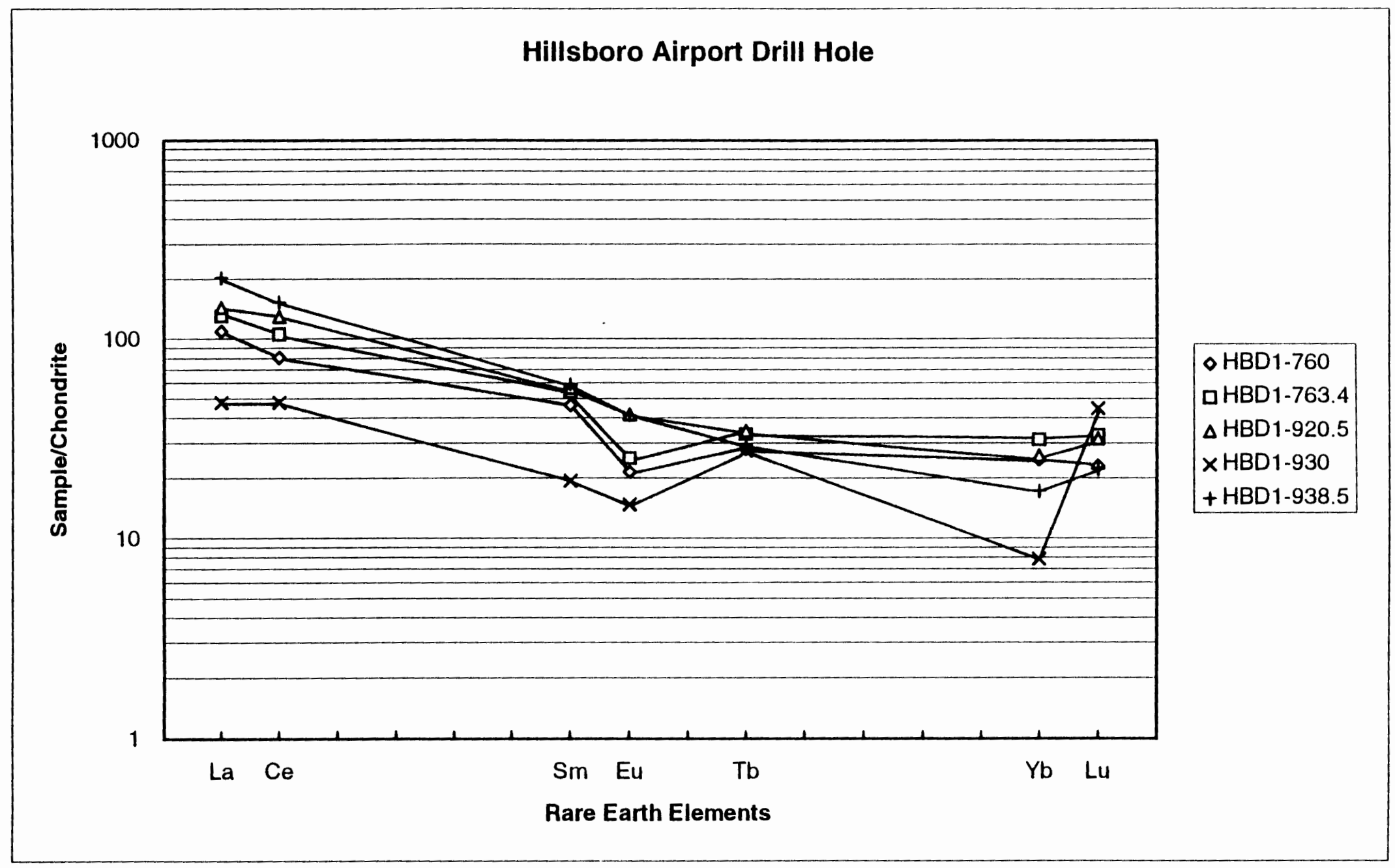

Figure 38. Hillsboro Airport Drill Hole Sediments Chondrite Plot (CRBG Sediments and the ash layer @ 760 feet). 


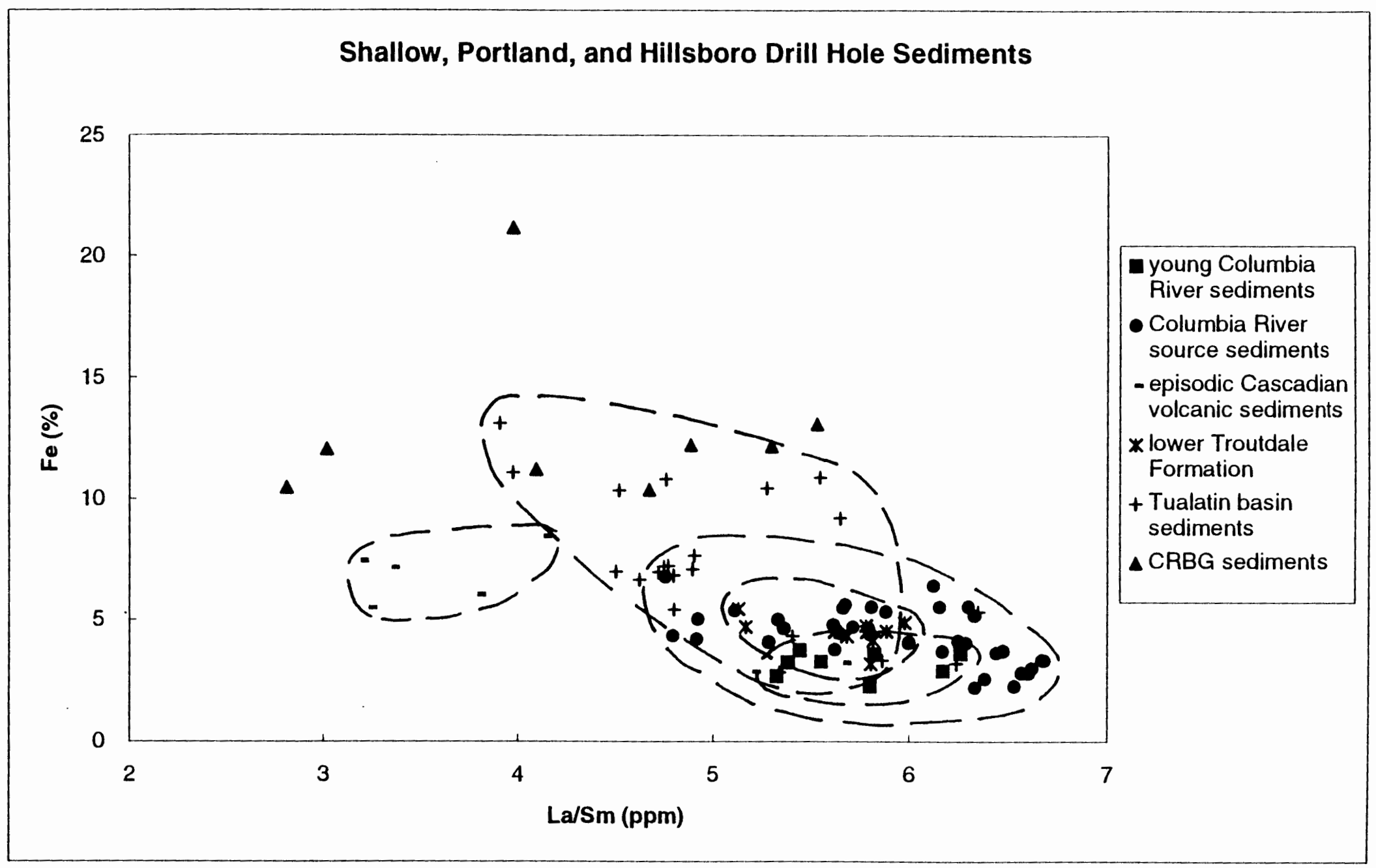

Figure 39. Shallow, Portland, and Hillsboro Drill Hole Sediments Scatter Plot (Lanthanum/Samarium vs. Iron). 


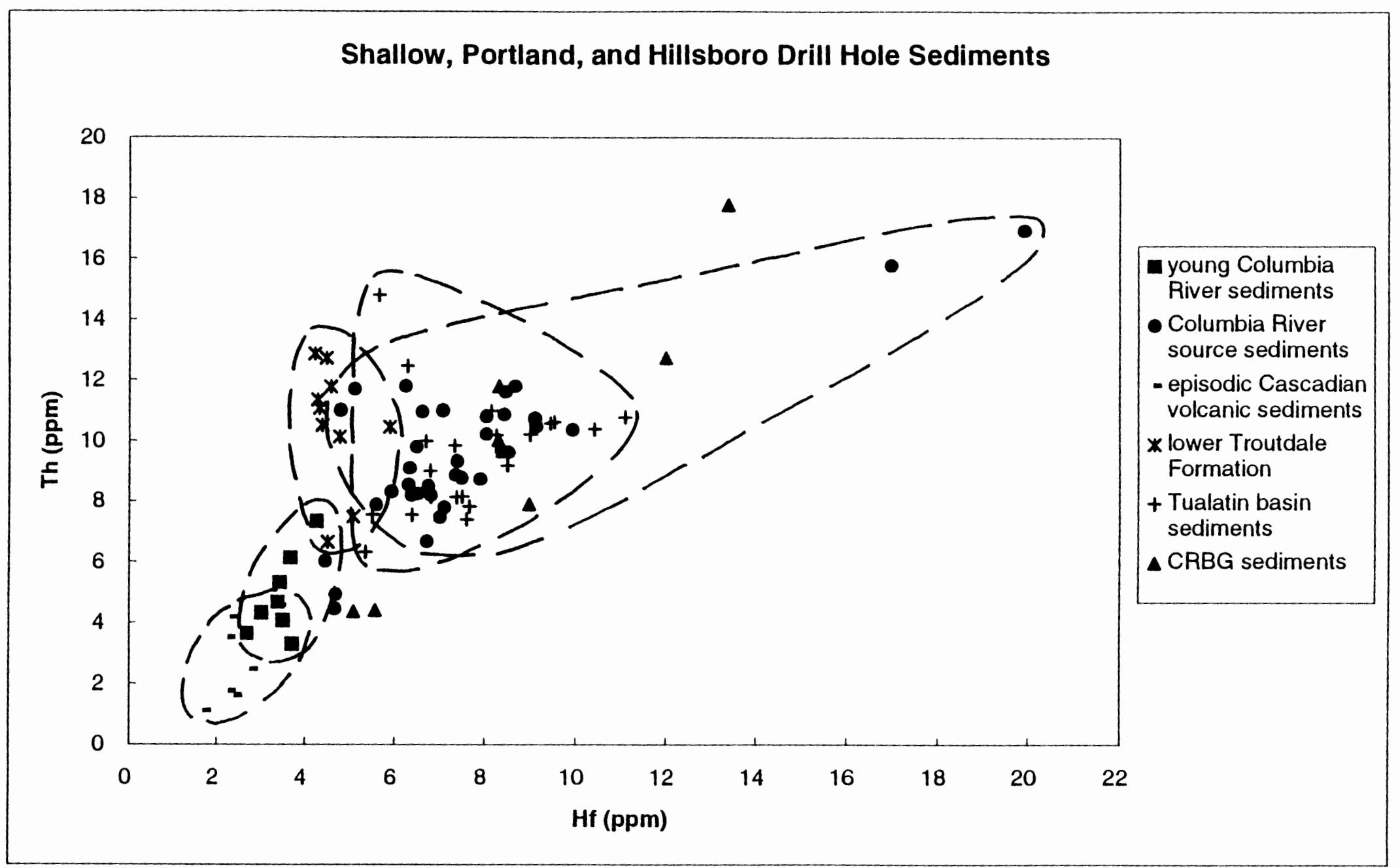

Figure 40. Shallow, Portland, and Hillsboro Drill Hole Sediments Scatter Plot (Hafnium vs. Thorium). 


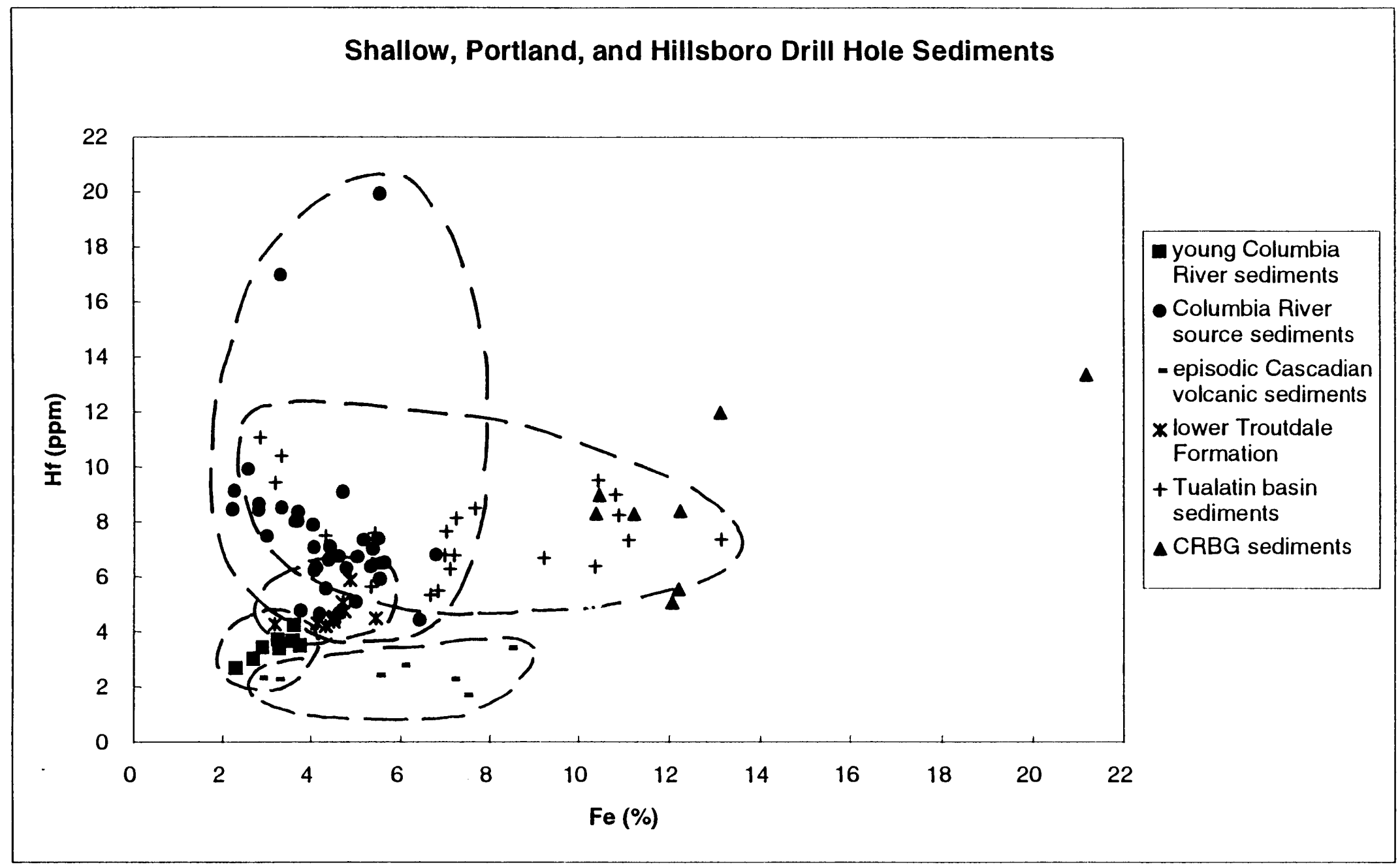

Figure 41. Shallow, Portland, and Hillsboro Drill Hole Sediments Scatter Plot (Iron vs. Hafnium). 
group, however, they do not generally occur within the lower Troutdale Formation geochemical group. On Figure 41, the Tualatin basin sediment samples from HBDI are found within the boundaries of the Columbia River source sediment geochemical and CRBG sediment groups. Although the Tualatin basin sediment samples collected from HBDI and the Columbia River source sediments may have similar concentrations of some elements, overall, they do not appear to be the same.

The geologic history of the Tualatin basin is currently under investigation (Wilson, 1994; personal communication). The geochemical data generated for the Tualatin basin for this study will be one of numerous additional data sets being collected to examine the stratigraphy and structure of the Tualatin basin.

\section{STATISTICAL ANALYSIS}

Basic statistical analyses were completed for the seven identified geochemical groups, which were chosen based on geochemistry, geology, and location. The statistical analyses were completed to show that the chosen geochemical groups are indeed distinguishable from one another. F tests were completed initially to examine the equality of the variances between the groups. Where the $F$ test failed to reject the equality of the variances, 
$\mathrm{T}$ tests were conducted to compare the means of the groups. Statistical analysis is presented in Appendix F.

Complete data sets were not available for all of the analyzed samples. As a result, only those samples having complete data sets were used to calculate the mean for that group. In addition, not all elements that had geochemical data available were used in the comparisons. Element choice was based on the counting error and the completeness of the data. In general, those elements having less than ten percent counting error and complete data sets were used in the statistical analysis. The elements used were $\mathrm{Na}, \mathrm{Cs}, \mathrm{Ba}, \mathrm{Fe}, \mathrm{Sc}, \mathrm{Cr}, \mathrm{Co}, \mathrm{Hf}, \mathrm{Th}, \mathrm{La}$, $\mathrm{Ce}, \mathrm{Sm}, \mathrm{Eu}$, and $\mathrm{Tb}$.

A total of $24 \mathrm{~F}$ tests were performed for the seven geochemical groups, using a 5\% significance level. In 16 cases, the equality of the variance was rejected for each set of sediment groups compared. In 8 cases, the equality of the variances was not rejected, and a $T$ test was conducted for that set of sediment groups, also using a $5 \%$ significance level. The equality of the means was rejected for each set of sediment groups compared. Thus, the seven, previously discussed groups, can be considered separate, distinct geochemical groups, as listed:

(1) Columbia River source sediments, (2) Lower Troutdale Formation, (3) CRBG sediments, (4) Reed Island ashes, 
(5) Young Columbia River sediments, (6) High-alumina basalt sediments, and (7) Episodic Cascadian volcanic sediments.

As shown previously in the discussion of the Columbia River source sediments, the Portland Hills silt did not appear to be distinguishable from the main Columbia River source sediment group on scatter plots, and statistically, it is not. Both $\mathrm{F}$ and $\mathrm{T}$ tests were conducted comparing these two groups. The equality of the variance and the equality of the mean was not rejected. The primary basis for the identification of the Portland Hills silt is its distribution, generally located on hilltops at shallow depths.

Also previously considered to be a likely part of the Columbia River source sediment, is the lower Troutdale Formation. The equality of the variance of these two groups was rejected in the $F$ test, resulting in the distinction of the lower Troutdale formation from the Columbia River source sediments. It should be noted that all of the lower Troutdale Formation samples were collected from MTD1. In order to confirm that the lower Troutdale Formation is conclusively a distinct geochemical group, samples from other locations should be collected and analyzed to increase the geographic distribution over which the statistical analyses are conducted. 


\section{DISCUSSION}

The seven previously discussed groups can be placed into three major geochemical categories as follows:

1. Columbia River or continental source

* Columbia River source sediments

* lower Troutdale Formation

2. Cascadian or local volcanic source

* young Columbia River sediments

* Reed Island ashes

* high-alumina basalt sediments

* episodic Cascadian volcanic sediments

3. Soils/sediments developed on a given rock type

* CRBG sediments

These three major geochemical categories, and the groups listed under them as identified in this study, can be placed into the current understanding of Portland area stratigraphy.

Materials deposited from the Columbia River or continental source include the Sandy River Mudstone, the lower Troutdale Formation, the Portland Hills Silt, and the Missoula Flood deposits. As stated previously, the Columbia River source sediment group defined in this study, includes the Sandy River Mudstone, the Portland Hills Silt, and the Missoula Flood deposits. In addition, those samples of sediment collected along the tunnel alignment from the Trimet drill core, are included in this group. In particular, the two sediment layers between the 
Boring Lava units could represent a Portland Hills Silttype depositional material (i.e. wind-blown), based on radiometric ages of the Boring Lavas and the fine grained, massive nature of the sediments. Geochemically, the Columbia River source sediments and lower Troutdale Formation are all very similar.

Materials representing a Cascadian or local source include the Clackamas River terraces and alluvium of Madin (1990), and the upper Troutdale Formation, the fluvial deposits and debris flows, and alluvium of Tolan and Beeson (1993).

The Reed Island ashes and the young Columbia River sediment are considered to be a part of the alluvium unit described by both Madin (1990) and Tolan and Beeson (1993). Both geochemical groups are interpreted to be relatively young sediments based on their stratigraphic positions. The Reed Island ashes are geochemically similar to the young Columbia River sediments because the Reed Island ashes have likely been reworked by the columbia River (Figures 15-20 and 33-35). The young Columbia River sediments are geochemically distinct from the Columbia River source sediments, as shown on Figures 16 and 17. The probable reason for this is the contribution of Cascadian-type materials to the Columbia River, introduced during the uplift of the Cascades within the last 2-3 Ma 
(Beeson and Tolan, 1990). The beginning of the uplift of the Cascades is considered to mark the end of Troutdale Formation deposition (Tolan and Beeson, 1984). The young Columbia River sediments, deposited during the uplift of the Cascades represent post-Troutdale deposition.

The high-alumina basalt sediments are considered a part of the Clackamas River terraces of Madin (1990) and/or the fluvial deposits and debris flows of Tolan and Beeson (1993). As stated previously, two of the three samples in this geochemical group are located near rivers (the Columbia and Clackamas Rivers) that would be carrying Cascadian material. The third sample is located at the base of Mt. Scott, on its west side, and is representative of the erosion of Boring Lava from Mt. Scott.

The episodic Cascadian volcanic sediments may represent the portions of the hyaloclastite layers observed in the upper Troutdale Formation by Tolan and Beeson (1984), and Swanson (1986). Hoffstetter (1984) also notes the presence of hyaloclastite beds in the hydrogeologic units that he presents. The episodic Cascadian volcanic sediments occur in the Portland International Airport Drill Hole (MTDI) at approximately 400 to 800 feet, with a non-volcanic unit occurring at 575 feet. The hyaloclastite beds examined by Swanson (1986), occur in the Portland well field exploratory wells, 
nearest to MTD1, at approximately 300 to 700 feet, with non-hyaloclastite material beginning between 500 to 550 feet and ending between 550 to 700 feet. The hyaloclastite beds observed by Hoffstetter (1984), occur in the Portland well field wells, nearest to MTD1, at approximately 350 to 600 feet $(600$ feet is the maximum depth shown on the cross section by Hoffstetter, 1984), and include the Troutdale Sandstone Aquifer and the Rose City Aquifer. A confining unit that contains no hyaloclastite material, the Rose City Aquitard, separates the two aquifers at approximately 400 to 500 feet. Table VII compares the approximate depths of volcanic or hyaloclastite materials in the wells examined for each study.

Table VII. Comparison of the depth of occurrence of volcanic or hyaloclastite materials in wells examined by Hoffstetter (1984) and Swanson (1986) near MTD1.

\begin{tabular}{|c|c|c|c|}
\hline Author & $\begin{array}{c}\text { Hoffstetter } \\
(1984)\end{array}$ & $\begin{array}{c}\text { Swanson } \\
(1986)\end{array}$ & $\begin{array}{l}\text { Barnes } \\
(1995)\end{array}$ \\
\hline $\begin{array}{c}\text { Hyaloclastite } \\
\text { /Volcanic } \\
\text { Unit }\end{array}$ & $\begin{array}{c}350 \text { to } 400 \\
\text { feet }\end{array}$ & $\begin{array}{c}300 \text { to } 500- \\
550 \text { feet }\end{array}$ & $\begin{array}{c}400 \text { to } 575 \\
\text { feet }\end{array}$ \\
\hline $\begin{array}{l}\text { Non- } \\
\text { hyaloclastite } \\
\text { Unit }\end{array}$ & $\begin{array}{c}400 \text { to } 500 \\
\text { feet }\end{array}$ & $\begin{array}{l}500-550 \text { to } \\
550-700 \text { feet }\end{array}$ & 575 feet \\
\hline $\begin{array}{c}\text { Hyaloclastite } \\
\text { /Volcanic } \\
\text { Unit }\end{array}$ & $\begin{array}{c}500 \text { to } 600 \\
\text { feet }\end{array}$ & $\begin{array}{c}550 \text { to } 700 \\
\text { feet }\end{array}$ & $\begin{array}{c}575 \text { to } 800 \\
\text { feet }\end{array}$ \\
\hline
\end{tabular}


The depths at which the volcanic materials occur, as determined in each study, show a good correlation. This would seem to indicate that the episodic Cascadian volcanic sediments identified in this study are indeed correlative to the hyaloclastite units described by Hoffstetter (1984) and Swanson (1986). If this is the case, then that makes the episodic Cascadian volcanic sediments a part of the upper Troutdale Formation.

The last of the three major geochemical groups represents soils and/or sediments located directly on top of solid rock units. In particular, several sediment samples collected overlying CRBG rock have been shown, geochemically, to represent weathered or residual CRBG material.

Having discussed the geochemistry of the collected samples, and placed the units defined in this study into the current stratigraphic framework, it is apparent that the sediment packages of the Portland and Tualatin basins are quite different. Finer grained volcanic sediments were identified in the Tualatin basin, while both fine and coarse grained volcanic sediments were identified in the Portland basin. This would seem logical as the Portland basin is geographically closer to the Cascades than is the Tualatin basin. The variable appearance of the sediments in the Portland International Airport Drill Hole (MTD1), 
compared to the generally uniform appearance of the sediments in the Hillsboro Airport Drill Hole (HBD1), can be attributed to the proximity of MTDI to an active river channel and volcanic arc.

The differences in the grain size of the sediments observed in each basin might also be attributed to the difference in the types of source rock that contribute to the load carried by rivers draining into the two basins. The materials being transported by the Columbia River (before dams) tend to be of larger grain sizes due to the plutonic/granitic-type rock over which the Columbia River flows. Plutonic or granitic types of rock generally break down to sand-sized grains. The Tualatin basin does not currently receive depositional materials from the Columbia River, and no plutonic/granitic-type source rocks are present in the drainages that empty into the Tualatin basin.

In addition, the rise of the Tualatin Mountains would have effectively separated the basins, and likely routed an ancestral Columbia River around them to the north, much as it flows today. The result of the new path of the Columbia River would prevent the distribution of similar depositional materials throughout the two basins. It is possible that the rise of the Tualatin Mountains took place early on in the history of the two basins. As 
stated before, the two basins are lithilogically distinct. As shown previously on the scatter plots (Figure 39-41) and in the Hillsboro Airport Drill Hole discussion, the sediments from the Hillsboro Airport Drill Hole do not tend to plot consistently with the other geochemical groups identified in the Portland basin.

Several large differences in the sediment packages of the two basins are obvious. First, the volcanic ash unit identified at 760 feet in $\mathrm{HBD} 1$ is not identified in MTD1. The volcanic ash layer in HBD1 is approximately 3 feet thick, and likely represents a large volcanic eruption, that should be observed throughout the Portland area. However, because MTD1 is located so close to the Columbia River channel, it is likely that the Columbia River had a direct affect on what materials would be preserved in the area of MTD1. It is entirely possible that the Columbia River eroded away the record, in MTD1, of the volcanic ash observed at 760 feet in $\mathrm{HBD} 1$.

Likewise, the young Columbia River sediment and episodic Cascadian volcanic sediments are present only in the Portland basin. Again, the proximity of MTD1 to the Columbia River channel is the likely reason. Both units were deposited by the Columbia River, and if the Tualatin Mountains did rise early, then the sediments deposited by 
the Columbia River would not have been transported into the Tualatin basin.

It is also possible that the volcanic ash layer in HBD1, and the episodic Cascadian volcanic sediments in the MTD1 different phases or stages in one or more volcanic periods of the Cascades. The volcanic ash may be a distal deposit of a large explosive eruption, while the episodic Cascadian volcanic sediments may represent more proximal materials deposited and eroded nearer the river, or deposited directly in the river. Even though both basins may have been separate basins early on during post-CRBG time, their stratigraphy may be tied together by one or more of these types of large-scale events. 


\section{CONCLUSIONS}

The purpose of this study was to analyze volcanic rock and sediment samples using INAA to produce geochemical data useful in better understanding the geologic history of the Portland area. In the case of the volcanic rock, the INAA geochemistry was used in conjunction with three other data sets to identify the distribution of Boring Lava along the west side of the Tualatin Mountains, near Highway 26. Three flows were identified: the Boring Lava of Barnes Road, the Boring Lava of Sylvan Hill, and the Boring Lava of Cornell Mountain. Geochemistry, radiometric age, and magnetic polarity data allowed a surface map and a cross section to be presented for portions of that area.

In the case of the sediment samples, INAA geochemistry allowed the identification of seven geochemical sediment groups. These seven groups can be placed into three major geochemical categories:

Columbia River or continental source

1. Columbia River source sediments

2. lower Troutdale Formation 
Cascadian or local source

3. young Columbia River sediments

4. Reed Island ashes

5. high-alumina basalt sediments

6. episodic Cascadian volcanic sediments

Soils/sediments developed on a given rock type

7. CRBG sediments

All seven of the groups were identified in the Portland basin. Only one of the seven groups (CRBG sediments) was identified at the base of the Hillsboro Airport Drill Hole (lower 200 feet) in the Tualatin basin. Data obtained for the additional Hillsboro Airport Drill Hole samples showed no trends or patterns, with the exception of the volcanic ash layer at 760 feet. This volcanic ash layer was not observed in the Portland basin.

Two main conclusions can be suggested about the history of the Portland and Tualatin basins. The first is that the two basins are distinct, and have been since early in post-CRBG time. Visually and geochemically, their sediment packages are very different. The second conclusion is that the position of MTD1 in relation to the current and ancestral Columbia River channels, and in relation to the Cascades (an active volcanic arc) would provide the opportunity for a more varied sediment record to be preserved over time. The Tualatin basin is located farther from the Cascades, and is not cut by the river that is the channel through which all the waters of the 
Columbia River drainage basin must eventually flow to reach the Pacific Ocean.

Finally, each of the seven sediment groups was able to be placed into the current stratigraphic framework of Madin (1990) and Tolan and Beeson (1993). The Columbia River source sediment group includes the Portland Hills Silt, Sandy River Mudstone, and Missoula Flood deposits. The lower Troutdale Formation is clearly a part of the Troutdale Formation. The young Columbia River sediments and the Reed Island ashes are considered a part of the recent alluvium described by both Madin (1990) and Tolan and Beeson (1993). The high-alumina basalt sediments are interpreted to represent the Clackamas River terraces of Madin (1990) and/or the fluvial deposits and debris flows of Tolan and Beeson (1993). The episodic Cascadian volcanic sediments are believed to be a part of the upper Troutdale Formation.

Based on the identification of the seven geochemical groups and their locations within the Portland basin, it has been demonstrated that INAA is an effective tool for working out stratigraphy in the Portland area. Based on the placement of those seven groups into three broad geochemical categories, it has been demonstrated that INAA is also an effective tool for addressing questions regarding Portland area geologic history. 
FUTURE WORK

In general, more questions seem to be generated from research than are answered. This study is no different. Many additional areas of study would further our understanding of the geology and geologic history of the Portland area. Several projects are listed below:

1. Increasing the number of samples analyzed for the sediment groups. Now that the groundwork has been laid, additional sampling based on the results of this study would aid in more precisely defining the positions, vertically and horizontally, of geochemical units.

2. The Tualatin basin sediments seem to remain a mystery. Additional analyses of Tualatin basin sediments and possible source areas may clarify the situation.

3. The shallow sediments in the Portland and Tualatin basins have been generally characterized. However, those samples primarily represent the upper 300 feet of material, and in many cases much less. Also, in 
most cases, only one sample per shallow drill hole was analyzed. A more complete sampling of the shallow drill holes would provide additional information in studying basin stratigraphy.

4. The grain size of the analyzed samples could be determined to identify any relation between grain size and geochemistry. In addition, the percentage of volcanic material could be quantified to determine at approximately what percentage a sediment will indicate a volcanic source area (provenance).

5. Additional samples of Boring Lava should be collected along the western side of the Tualatin Mountains to determine the extent of the oldest reverse flow of Cornell Mountain, and to identify what type of Boring Lava lies to the northwest. 
Allen, J. E., 1975, Volcanoes of Portland, Oregon: The Ore Bin, v. 37, n. 9, p. 145-157.

Balsillie, J. H. and Benson, G. T., 1971, Evidence for the Portland Hills Fault: The Ore Bin, v. 33, n. 6, p. 109-118.

Beeson, M. H., 1993, personal communication.

Beeson, M. H., Johnson, A. G., and Moran, M. R., 1975, Portland environmental geology--fault identification: United States Geological Survey Earthquakes Hazards Reduction Program Final Technical Report, 107p.

Beeson, M. H., Fecht, K. R., Reidel, S. P., and Tolan, T. L., 1985, Regional Correlations within the Frenchmen Springs member of the Columbia River Basalt Group; New insights into the middle Miocene tectoncis of northwestern Oregon: Oregon Geology, v. 47, n. 8, p. $87-96$.

Beeson, M. H., Tolan, T. L., and Anderson, J.L., 1989, The Columbia River Basalt Group in western Oregon; Geologic structures and other factors that controlled flow emplacement patterns: Geological society of America Special Paper 239, p. 223-246.

Beeson, M. H. and Tolan, T. L., 1990, The Columbia River Basalt Group in the Cascade Range: A middle Miocene reference datum for structural analysis: Journal of Geophysical Research, v. 95, n. B12, p. 19,54719,559 .

Beeson, M. H., Tolan, T. L., and Madin, I. P., 1991, Geologic map of the Portland Quadrangle, Multnomah and Washington Counties, Oregon, and Clark County, Washington: Oregon Department of Geology and Mineral Industries Map GMS 75, 1:24,000.

Bhatia, M. R. and Taylor, S. R., 1981, Trace-element geochemistry and sedimentary provinces: A study from the Tasman Geosyncline, Australia: Chemical Geology, v. 33, p. 115-125. 
Blakely, R. J., Wells, R. E., Yelin, T. S., Madin, I. P., and Beeson, M. H., 1995, Tectonic setting of the Portland-Vancouver area, Oregon and Washington: Constraints from low-altitude aeromagnetic data: Geological Society of America Bulletin, v.107, n. 9, p. 1051-1062.

Conrey, R., 1995, personal communication.

Ekambarum, V., Kawabe, I., Tanaka, T., Davis, A. M., and Grossman, L., 1984, Chemical compositions of refractory inclusions in the Murchison C2 chondrite: Geochimica et Cosmochima Acta, v. 48, p. 2089-2105.

Frank, F. J. and Collins, C. A., 1978, Groundwater in the Newberg area, Northern Willamette Valley, Oregon: United States Geological Survey Groundwater Report No. 27 .

Hart, D. H. and Newcomb, R. C., 1965, Geology and ground water of the Tualatin Valley, Oregon: United States Geological Survey Water-Supply Paper 1697, 169p.

Hoffstetter, W. H., 1984, Geology of the Portland Well Field: Oregon Geology, v. 46, n. 6, p. 63-67.

Hogenson, G. M. and Foxworthy, B. L., 1965, Ground water in the east Portland area, Oregon: United States Geological Survey Water-Supply Paper 1793, 78p.

Hooper, P. R., 1982, The Columbia River basalts: Science, v. 215, no. 4539, p. 1463-1468.

Kadri, M. M., Beeson, M. H., and Van Atta, R. O., 1983, Geochemical evidence for changing provenance of Tertiary formations in northwestern Oregon: Oregon Geology, v. 45, p. 20-22.

Madin, I. P., 1990, Earthquake-hazard geology maps of the Portland metropolitan area, Oregon: Oregon Department of Geology and Mineral Industries OpenFile Report 0-90-2, 21p.

Madin, I. P., Priest, G. R. , Mabey, M. A., Malone, S., Yelin, T. S., and Meier, D., 1993, March 25, 1993, Scotts Mills earthquake - western Oregon's wake-up call: Oregon Geology, v. 55, n. 3, p. 51-57. 
McLennan, S. M. and Taylor, S. R., 1980, Th and $U$ in sedimentary rocks: crustal evolution and sedimentary recycling: Nature, v. 285, p. 621-624.

Muecke, G. K., ed., 1980, Short Course in Neutron Activation Analysis in the Geosciences:

Mineralogical Society of Canada, Halifax, Nova Scotia, 279p.

Piper, D., 1974, Rare earth elements in the sedimentary cycle: A summary: Chemical Geology, v.14, p.285304 .

PSU, 1987, Portland State University radiation safety program: Portland state University, Portland, Oregon, $15 \mathrm{p}$.

PSU, 1993, Advanced Geochemistry Class (G519): Portland State University, Portland, Oregon.

Schlicker, H. G., Deacon, R. J., and Twelker, N. H., 1964, Earthquake geology of the Portland area, Oregon: The Ore Bin, v. 26, n. 112, p. 209-230.

Schlicker, H. G. and Deacon, R. J., 1967, Engineering geology of the Tualatin Valley Region, Oregon: Oregon Department of Geology and Mineral Industries Bulletin 60, 87p.

Squier Associates, 1992, Westside Light Rail Tunnel Geotechnical Interpretive Report: Prepared for Tricounty Metropolitan Transport District Oregon.

Swanson, R. D., 1986, A stratigraphic-geochemical study of the Troutdale Formation and Sandy River Mudstone in the Portland Basin and lower Columbia River Gorge: Portland, Oregon, Portland State University master's thesis, $103 \mathrm{p}$.

Tolan, T. L. and Beeson, M. H., 1984, Intracanyon flows of the Columbia River Basalt Group in the lower Columbia River Gorge and their relationship to the Troutdale Formation: Geological Society of America, v. 95, p. $463-477$.

Tolan, T. L. and Beeson, M. H., 1993, Overview of the stratigraphy and structure of the Portland area: Association of Engineering Geologists Field Trip Guide, 26p. 
Tolan, T. L. and Reidel, S. P., 1989, Structure map of a portion of the Columbia River flood basalt province, in Reidel, S. P. and Hooper, P. R., eds.,

Volcanism and tectonism in the Columbia River floodbasalt province: Geological Society of America Special Paper 239, Plate 1.

Treasher, R. C., 1942, Geologic History of the Portland area: Oregon Department of Geology and Mineral Industries Short Paper 7.

Trimble, D. E., 1963, Geology of Portland, Oregon and Adjacent area: United States Geological Survey Bulletin 1119, 119p.

Wilson, D., 1994, personal communication.

Yeats, R. S., Graven, E. P., Werner, K. S., Goldfinger, C., and Popowski, T., 1991, Tectonics of the Willamette Valley, Oregon: United States Geological Survey Open File Report 91-441-P, 47p.

Yelin, T. D. and Patton, H. J., 1991, Seismotectonics of the Portland, Oregon region: Bulletin of the Seismological Society of America, v. 81, n. 1, p. 109-130. 
APPENDIX A

GEOCHEMICAL DATA FOR THE BORING LAVA 
BORING LAVA -- IRRADIATIONS 93D, 93E, AND 94A

Samples collected from outcrops and Trimet drill core.

* Concentrations in ppm except $\mathrm{Na}, \mathrm{K}$, and $\mathrm{Fe}$

Irrad. Sample

Number Number

DI

b $557-38-52$

$\mathrm{D} 2$

b557-80-94

D3 b54I-27

D4 b556-57

D5

b556-95

D6

D7

b557-165

D8

b540-213

D9

b564-115

D10

b5 $54-170$

D11

D12

D13

D14

D15

D16

D17

D28T

$\mathrm{D} 29 \mathrm{~T}$

D22

D23

D2 6

D2 7

E1

E2

E3

E4

E5

E6

E7

E8

E9

E10

b538-176

b538-28.5

b539-42

b539-167.7

$\mathrm{Na} \%$

$\mathrm{K} \%$

$\mathrm{Rb}$

Cs

30

5.54

666

25

$3.08 \quad 1.09 \quad 625$

3.041 .18

22

2.98

1.30

39

$3.09 \quad 1.17 \quad 759$

2. 91

1.30

42

3.04

1.30

710

2.96

1.20

589

2. 95

1. 30

14

3.09

1.50

619

2.86

1.00

503

b555-95

3.07

0.96

485

b555-190

b561-98

2.80

1.40

456

b561-166

3. 12

1.40

36

4.40

10.47

3.20

2.84

7.66

7.20

7.20
4.33

6.67

7.02

3.33

5.42

1. 11

9. 21

6.98

547

10.37

1.20

675

b540-34

2.84

1.50

7.10

629

3.06

1.40

10.90

b561-172

2.64

0.66

b561-135

1.97

0.91

18

1. 59

0.89

b557-211

2.77

1. 22

271

21.18

2.67

2.05

$\mathrm{KAI}$

2.25

0.88

23

2.22

1. 46

CR3

2.72

1.05

556

2.26

2. 92

CY5

3. 18

1.01

516

1.41

666

0.58

BA7

2.99

1.60

531

2.87

1. 78

0.81

2.86

0.92

1. 16

SH9

3.08

1.62

30

1. 12

620

1.38

HWY 2 6-2

3.04

1.46

21

0.71

HWY 26-4

2.92

1. 31

12

0.44

EI2 ODOT-K108-48-49

3.06

1.32

18

0.39

1.12

36

1.38

1.08

28

2.38

3.03

1.43

619

5.23

B $541-27$
B557-32

3.04

36

3.33

0.76

1. 31

485

27

0.46

I. 52

3.06

1.07

31

2.13

1. 52

547

0.75

Sr $\mathrm{Ba}$

$930 \quad 390$

$770 \quad 330$

$720 \quad 440$

$730 \quad 64$

$780 \quad 430$

$1103 \quad 436$

81791

$920 \quad 380$

$640 \quad 430$

$870 \quad 380$

$810 \quad 370$

$620 \quad 450$

$590 \quad 310$

$763 \quad 335$

$696 \quad 328$

$849 \quad 74$

$548 \quad 311$

$660 \quad 330$

$730 \quad 440$

881313

$921 \quad 296$

$1163 \quad 531$

$1040 \quad 546$

$416 \quad 599$

$866 \quad 554$

$967 \quad 607$

$958 \quad 640$

$798 \quad 454$

$778 \quad 472$

$1016 \quad 652$

$847 \quad 491$

891584

$\begin{array}{ll}775 & 434\end{array}$

$776 \quad 417$

858463

621711

$784 \quad 646$

$800 \quad 511$

$830 \quad 470$

$788 \quad 434$

$789 \quad 487$

E20

B12-119

2.94

0.95

1005

498

$860 \quad 461$ 
Irrad. Sample

\begin{tabular}{|c|c|c|c|c|c|c|c|}
\hline Numb & Number & $F e \%$ & Sc & $\mathrm{Cr}$ & Co & $\mathrm{Zx}$ & Hf \\
\hline $\mathrm{D} 1$ & b557-38-52 & 6.25 & 19.1 & 173 & 31 & 17 & 3.40 \\
\hline D2 & b557-80-94 & 5.26 & 16.5 & 141 & 26 & 11 & 3.00 \\
\hline D3 & b5 $41-27$ & 6.12 & 19.1 & 169 & 30 & 8 & 3.60 \\
\hline D4 & b556-57 & 6.18 & 19.3 & 159 & 29 & 11 & 3.60 \\
\hline D5 & b556-95 & 5.86 & 18.5 & 161 & 28 & 350 & 3.50 \\
\hline D6 & b557-165 & 5.76 & 16.7 & 205 & 32 & 240 & 3.61 \\
\hline D7 & b540-213 & 6.03 & 22.9 & 190 & 34 & 15 & 3.36 \\
\hline D8 & b564-115 & 5.54 & 16.5 & 267 & 34 & 9 & 3.60 \\
\hline D9 & b5 $564-170$ & 6.54 & 22.9 & 210 & 35 & 8 & 3.60 \\
\hline D10 & b538-176 & 6.57 & 21.9 & 205 & 35 & 240 & 3.7 \\
\hline D11 & b538-28.5 & 6.09 & 18.2 & 178 & 30 & 8 & 3.7 \\
\hline D12 & b5 $59-42$ & 6.14 & 18.0 & 185 & 30 & 250 & 3.5 \\
\hline D13 & b539-167.7 & 6.24 & 24.3 & 179 & 34 & 230 & 3.26 \\
\hline D14 & $b 555-95$ & 6.37 & 25.3 & 166 & 35 & 256 & $3.2 \varepsilon$ \\
\hline D15 & b555-190 & 5.96 & 22.0 & 175 & 32 & 210 & 3.06 \\
\hline D16 & $561-98$ & 6.20 & 20.6 & 253 & 36 & 8 & 3.5 \\
\hline D17 & b561-166 & 5.59 & 21.4 & 155 & 32 & & 3.05 \\
\hline $\mathrm{D} 28 \mathrm{~T}$ & $540-34$ & 5.09 & 15.6 & 142 & 24 & 330 & 3.26 \\
\hline $\mathrm{D} 29 \mathrm{~T}$ & $540-90$ & 5.94 & 17.6 & 179 & 29 & 370 & 4.0 \\
\hline D22 & $561-172$ & 6.43 & 24.2 & 178 & 34 & 258 & 3.72 \\
\hline D23 & $561-135$ & 5.70 & 18.8 & 255 & 32 & 231 & 3.34 \\
\hline D26 & $557-211$ & 6.35 & 17.4 & 224 & 33 & & 3.43 \\
\hline D27 & $b 557-213$ & 6.21 & 16.3 & 231 & 32 & & 3.8 \\
\hline E1 & $\mathrm{KAI}$ & 7.44 & 22.2 & 321 & 44 & 183 & $4.3=-3(-3)$ \\
\hline E2 & SS2 & 6.72 & 18.5 & 201 & 33 & 134 & 3.8 \\
\hline E3 & CR3 & 6.26 & 22.3 & 184 & 34 & 194 & 3.1 \\
\hline E4 & CY5 & 6.92 & 18.4 & 165 & 33 & 269 & 3.8 \\
\hline E5 & CY6 & 6.22 & 20.4 & 247 & 35 & 135 & 3.47 .3$. \\
\hline E6 & BA7 & 6.35 & 16.3 & 168 & 30 & 137 & 3.7 \\
\hline E7 & BU8 & 6.48 & 18.2 & 227 & 36 & 249 & 3.4 \\
\hline E8 & SH9 & 6.50 & 20.4 & 193 & 33 & 118 & 4.0 \\
\hline E9 & HWY 26-2 & 6.60 & 18.6 & 194 & 32 & 264 & 3.7 \\
\hline E10 & HWY 26-3 & 5.67 & 17.0 & 165 & 28 & 177 & 3.6 \\
\hline E11 & HWY $26-4$ & 6.32 & 17.2 & 195 & 30 & 127 & 4.0 \\
\hline E12 & ODOT-K108-48-49 & 5.83 & 16.0 & 153 & 28 & 140 & 3.3 \\
\hline E13 & CLAR-110-120 & 6.91 & 19.3 & 136 & 38 & 385 & 8.8 \\
\hline E14 & B541-27 & 6.76 & 18.8 & 210 & 34 & 181 & 3.8 \\
\hline E15 & B557-32 & 6.36 & 17.5 & 191 & 32 & 159 & 3.5 \\
\hline E16 & B $557-93.5$ & 6.31 & 17.6 & 188 & 32 & 157 & 3.3 \\
\hline E17 & B14-37.5 & 6.33 & 15.3 & 205 & 30 & 102 & \\
\hline E18 & B537-155 & 6.79 & 19.1 & 217 & 36 & 110 & 3.4 \\
\hline E19 & B $12-94$ & 6.80 & 17.1 & 319 & 41 & 155 & \\
\hline E20 & $\mathrm{B} 12-119$ & 6.69 & 21.5 & 205 & 37 & 213 & \\
\hline
\end{tabular}


Irrad. Sample

\begin{tabular}{|c|c|c|c|c|c|c|c|}
\hline Numbe & Number & $\mathrm{Ta}$ & Th & $\mathrm{U}$ & $\mathrm{Zn}$ & As & $\mathrm{Sb}$ \\
\hline D1 & $b 557-38-52$ & 0.46 & 1.6 & 0.8 & 100 & & 11.3 \\
\hline D2 & b557-80-94 & 0.47 & 1.8 & 1.2 & 93 & & 7.2 \\
\hline D3 & b54l-27 & 0.47 & 1.6 & & 100 & & 13.6 \\
\hline D4 & b556-57 & 0.47 & 1.6 & 0.7 & 100 & 42.0 & 7.0 \\
\hline D5 & b556-95 & 0.46 & 1.6 & & 93 & 45.6 & 8.4 \\
\hline D6 & b557-165 & 0.75 & 2.4 & 1.7 & 110 & 25.6 & 5.6 \\
\hline D7 & $b 540-213$ & 0.55 & 1.7 & 0.5 & 112 & 40.6 & 7.6 \\
\hline D8 & b564-115 & 0.28 & 3.2 & & 79 & 43.0 & 9.0 \\
\hline D9 & b564-170 & 0.49 & 1.5 & 1.0 & 110 & 30.0 & 5.9 \\
\hline D10 & b538-176 & 0.50 & 1.4 & 1.4 & 110 & & 5.2 \\
\hline D11 & b5 $58-28.5$ & & 1.7 & 4.8 & 99 & 26.1 & 5.9 \\
\hline $\mathrm{D} 12$ & b5 $539-42$ & 0.49 & 2.1 & 0.9 & 96 & 41.4 & 6.5 \\
\hline D13 & b539-167.7 & 0.42 & 1.6 & & 100 & 26.1 & 5.5 \\
\hline D14 & b555-95 & 0.44 & 1.3 & & 114 & 28.5 & 6.6 \\
\hline D15 & b555-190 & 0.62 & 1.4 & & 99 & & 3.8 \\
\hline D16 & b561-98 & 0.73 & 3.3 & 2.8 & 100 & 64.5 & 7.0 \\
\hline D17 & b561-166 & 0.47 & 1.8 & & 101 & 38.6 & 7.5 \\
\hline $\mathrm{D} 28 \mathrm{~T}$ & b5 $540-34$ & 0.38 & 1.3 & 2.5 & 82 & 44.8 & 8.6 \\
\hline D29T & $b 540-90$ & 0.45 & 1.6 & & 100 & 42.4 & 7.8 \\
\hline D22 & b561-172 & 0.53 & 2.6 & 10.6 & 106 & 45.3 & \\
\hline D23 & b56I-135 & 0.67 & 3.4 & 2.1 & 84 & 6.4 & 12.0 \\
\hline D26 & b557-211 & 0.62 & 2.6 & 1.2 & 93 & 85.7 & 2.8 \\
\hline D27 & b557-213 & 0.67 & 2.7 & & 83 & & \\
\hline E1 & KAI & 5.19 & 2.6 & 11.9 & 102 & 24.5 & 7.7 \\
\hline E2 & SS2 & 3.63 & 2.0 & 8.0 & 107 & 37.5 & 6.5 \\
\hline E3 & $\mathrm{CR} 3$ & 3.74 & 1.6 & 0.8 & 100 & 20.5 & 6.6 \\
\hline E4 & CY5 & 3.00 & 2.1 & 8.1 & 103 & 25.7 & 11.3 \\
\hline E5 & CY6 & 3.40 & 1.5 & 11.8 & 99 & 31.0 & 7.2 \\
\hline E6 & BA7 & 5.64 & 1.7 & 1.3 & 93 & 14.5 & 2.3 \\
\hline E7 & BU8 & 3.36 & 2.9 & 10.4 & 100 & 13.3 & 7.0 \\
\hline E8 & SH9 & 0.57 & 2.1 & 1.7 & 114 & 5.3 & 8.4 \\
\hline E9 & HWY2 6-2 & 2.90 & 1.9 & 1.7 & 107 & 25.6 & 5.6 \\
\hline E10 & HWY26-3 & 2.11 & 1.6 & 2.4 & 87 & 32.6 & 7.6 \\
\hline E11 & HWY26-4 & 4.47 & 1.8 & 9.0 & 96 & 46.0 & 2.0 \\
\hline E12 & ODOT-K108-48-49 & 3.41 & 1.6 & 3.2 & 90 & 12.7 & 6.2 \\
\hline E13 & CLAR - $110-120$ & 5.09 & 9.0 & 3.8 & 90 & 7.5 & 5.2 \\
\hline E14 & B541-27 & 3.85 & 1.7 & 10.6 & 119 & 26.1 & 8.3 \\
\hline E15 & B557-32 & 3.57 & 1.6 & 14.9 & 100 & 41.4 & 6.5 \\
\hline E16 & B557-93.5 & 3.41 & 1.5 & 10.3 & 103 & 26.1 & 6.0 \\
\hline 17 & $\mathrm{~B} 14-37.5$ & 6.55 & 1.9 & 20.4 & 98 & 133.7 & 6.6 \\
\hline 18 & B537-155 & 8.35 & 1.8 & 10.0 & 103 & 74.4 & 3.8 \\
\hline 19 & -94 & 7.52 & 3.7 & 1.8 & 95 & 27.2 & 7 \\
\hline 20 & B12-119 & 8.52 & 1.6 & 16.1 & 101 & 38.6 & 5.1 \\
\hline
\end{tabular}




\begin{tabular}{|c|c|c|c|c|c|c|c|}
\hline Irra & Sample & & & & & & \\
\hline Numb & Number & La & $\mathrm{Ce}$ & $\mathrm{Nd}$ & $\mathrm{Sm}$ & Eu & $\mathrm{Tb}$ \\
\hline D1 & $b 557-38-52$ & & 38.3 & 5 & & 1.70 & 0.57 \\
\hline $\mathrm{D} 2$ & b557-80-94 & & 32.4 & 3 & & 1.50 & \\
\hline D3 & b541-27 & & 39.6 & 32 & & 1.70 & 0.63 \\
\hline D4 & b556-57 & 17.7 & 41.4 & 36 & 5.15 & 1.80 & 0.62 \\
\hline D5 & $b 556-95$ & 17.4 & 38.3 & 25 & 4.63 & 1.70 & 0.58 \\
\hline $\mathrm{D} 6$ & b557-165 & 26.4 & 57.9 & 33 & 5.61 & 1.69 & 0.61 \\
\hline D7 & b540-213 & 16.5 & 35.6 & 20 & 4.42 & 1.48 & 0.60 \\
\hline D8 & b5 $64-115$ & 25.9 & 49.5 & 29 & 5.39 & 1.60 & \\
\hline D9 & b564-170 & 15.7 & 35.0 & 3 & 4.39 & 1.50 & 0.70 \\
\hline $\mathrm{D} 10$ & b538-176 & 14.8 & 33.0 & 3 & 4.15 & 1.50 & 0.60 \\
\hline D11 & b5 $538-28.5$ & 17.3 & 39.0 & 3 & 4.94 & 1.70 & 0.66 \\
\hline $\mathrm{D} 12$ & b5 $59-42$ & 18.3 & 40.0 & 3 & 4.80 & 1.70 & 0.80 \\
\hline D13 & b539-167.7 & 16.7 & 31.0 & 3 & 4.59 & 1.70 & 0.60 \\
\hline D14 & b555-95 & 15.7 & 34.0 & 30 & 4.11 & 1.50 & \\
\hline D15 & b555-190 & 16.7 & 34.8 & 29 & 4.23 & 1.50 & 0.57 \\
\hline D1 6 & b56I-98 & 25.0 & 54.5 & 39 & 5.13 & 1.80 & 0.65 \\
\hline D17 & $\mathrm{b} 561-166$ & 16.1 & 31.8 & 3 & 4.32 & 1.40 & 0.85 \\
\hline $\mathrm{D} 28 \mathrm{~T}$ & b5 $540-34$ & 16.2 & 33.0 & 4 & 4.40 & 1.40 & 0.53 \\
\hline $\mathrm{D} 29 \mathrm{~T}$ & b5 $40-90$ & 17.3 & 38.0 & 22 & 4.60 & 1.70 & 0.57 \\
\hline D22 & b561-172 & 19.1 & 39.5 & 27 & 4.94 & 1.75 & \\
\hline $\mathrm{D} 23$ & b5 $5 I-135$ & 19.4 & 42.4 & & 4.54 & 1.30 & 0.54 \\
\hline $\mathrm{D} 26$ & b557-211 & 32.3 & 62.2 & 40 & 7.23 & 2.18 & 0.79 \\
\hline D27 & b557-213 & 31.3 & 61.0 & & 6.60 & 2.02 & 0.65 \\
\hline EI & $\mathrm{KAI}$ & 30.0 & 51.3 & 27 & 6.70 & 2.01 & 0.84 \\
\hline E2 & SS2 & 19.5 & 43.2 & 3 & 5.30 & 1.85 & 0.68 \\
\hline E3 & CR3 & 27.8 & 35.9 & 3 & 7.00 & 2.03 & 0.87 \\
\hline E4 & CY5 & 25.7 & 53.5 & 110 & 6.20 & 2.10 & 0.76 \\
\hline E5 & CY6 & 20.5 & 42.6 & 3 & 4.90 & 1.60 & 0.59 \\
\hline E6 & BA7 & 20.8 & 45.0 & 18 & 5.70 & 1.76 & 0.62 \\
\hline E7 & BU8 & 32.0 & 66.3 & 3 & 6.80 & 2.03 & 0.69 \\
\hline E8 & SH9 & 21.6 & 45.7 & 3 & 5.50 & 1.82 & 0.69 \\
\hline E9 & HWY2 $6-2$ & 20.4 & 46.8 & 3 & 5.40 & 1.90 & 0.68 \\
\hline E10 & HWY $26-3$ & 20.1 & 37.4 & 24 & 5.20 & 1.56 & 0.57 \\
\hline E11 & HWY26-4 & 19.5 & 43.1 & 25 & 5.30 & 1.71 & 0.60 \\
\hline $\mathrm{E} 12$ & ODOT-KI $08-48-49$ & 21.8 & 42.6 & 3 & 5.70 & 1.71 & 0.59 \\
\hline $\mathrm{E} 13$ & CLAR-110-120 & 41.3 & 84.6 & 3 & 7.90 & 2.05 & 1.12 \\
\hline E14 & B541-27 & 20.5 & 45.2 & 3 & 5.47 & 1.87 & 0.67 \\
\hline E15 & B557-32 & 19.0 & 40.6 & 3 & 4.87 & 1.67 & 0.62 \\
\hline E16 & B557-93. 5 & 18.6 & 38.6 & 3 & 5.00 & 1.74 & 0.63 \\
\hline E17 & $\mathrm{B} 14-37.5$ & 20.6 & 43.5 & 25 & 5.18 & 1.70 & 0.63 \\
\hline E18 & B537-155 & 18.0 & 35.4 & 2 & 4.49 & 1.53 & 0.65 \\
\hline E19 & B12-94 & 28.4 & 62.5 & 3 & 5.94 & 1.92 & 0.65 \\
\hline E20 & B12-119 & 16.3 & 35.7 & 60 & 4.34 & 1.58 & 0.67 \\
\hline
\end{tabular}


Irrad. Sample

$\begin{array}{llll}\text { Number } & \text { Number } & \text { Yb } & \text { Lu } \\ \text { D1 } & \text { b557-38-52 } & 1.50 & 0.21 \\ \text { D2 } & \text { b557-80-94 } & 1.50 & 0.25 \\ \text { D3 } & \text { b541-27 } & 1.80 & 0.22 \\ \text { D4 } & \text { b556-57 } & 1.80 & 0.26 \\ \text { D5 } & \text { b556-95 } & 1.70 & 0.31 \\ \text { D6 } & \text { b557-165 } & 1.41 & 0.19 \\ \text { D7 } & \text { b540-213 } & 2.09 & 0.31 \\ \text { D8 } & \text { b564-115 } & 1.40 & 0.12 \\ \text { D9 } & \text { b564-170 } & 2.10 & 0.36 \\ \text { D10 } & \text { b538-176 } & 2.20 & 0.31 \\ \text { D11 } & \text { b538-28.5 } & 1.80 & 0.33 \\ \text { D12 } & \text { b539-42 } & 1.60 & 0.41 \\ \text { D13 } & \text { b539-167.7 } & 2.30 & 0.34 \\ \text { D14 } & \text { b555-95 } & 2.33 & 0.31 \\ \text { D15 } & \text { b555-190 } & 2.09 & 0.29 \\ \text { D16 } & \text { b561-98 } & 1.43 & 0.23 \\ \text { D17 } & \text { b561-166 } & 1.83 & 0.28 \\ \text { D28T } & \text { b540-34 } & 1.50 & 0.20 \\ \text { D29T } & \text { b540-90 } & 1.60 & 0.25 \\ \text { D22 } & \text { b561-172 } & 2.32 & 0.38 \\ \text { D23 } & \text { b561-135 } & 1.32 & 0.22 \\ \text { D26 } & \text { b557-211 } & 1.81 & 0.24 \\ \text { D27 } & \text { b557-213 } & 1.78 & 0.22 \\ \text { E1 } & \text { KA1 } & 2.35 & 0.46 \\ \text { E2 } & \text { S52 } & 1.68 & 0.35 \\ \text { E3 } & \text { CR3 } & 2.61 & 0.49 \\ \text { E4 } & \text { CY5 } & 1.67 & 0.36 \\ \text { E5 } & \text { CY6 } & 1.63 & 0.43 \\ \text { E6 } & \text { BA7 } & 1.54 & 0.28 \\ \text { E7 } & \text { BU8 } & 1.67 & 0.30 \\ \text { E8 } & \text { SH9 } & 1.60 & 0.34 \\ \text { E9 } & \text { HWY26-2 } & 1.76 & 0.28 \\ \text { E10 } & \text { HWY26-3 } & 1.65 & 0.29 \\ \text { E11 } & \text { HWY26-4 } & 1.62 & 0.31 \\ \text { E12 } \text { ODOT-K108-48-49 } & 1.48 & 0.22 \\ \text { E13 } & \text { CLAR-110-120 } & 3.17 & 0.65 \\ \text { E14 } & \text { B541-27 } & 1.98 & 0.37 \\ \text { E15 } & \text { B557-32 } & 1.61 & 0.25 \\ \text { E16 } & \text { B557-93.5 } & 1.63 & 0.24 \\ \text { E17 } & \text { B14-37.5 } & 1.44 & 0.28 \\ \text { E18 } & \text { B537-155 } & 1.77 & 0.39 \\ \text { E19 } & \text { B12-94 } & 1.41 & 0.25 \\ \text { E20 } & \text { B12-119 } & 2.13 & 0.50\end{array}$


Irrad. Sample

$\begin{array}{llrrrrrr}\text { Number } & \text { Number } & \text { Na\% } & \text { K\% } & \text { Rb } & \text { Cs } & \text { Sr } & \text { Ba } \\ \text { E21 } & \text { B13-76.2 } & 2.85 & 1.62 & 36 & 1.90 & 940 & 520 \\ \text { E22 } & \text { B13-104.7 } & 2.75 & 1.57 & 34 & 1.31 & 986 & 558 \\ \text { E23 } & \text { B13-155 } & 3.03 & 0.96 & 12 & 0.47 & 874 & 371 \\ \text { E24 } & \text { B19-46 } & 3.07 & 1.15 & 727 & 4.10 & 876 & 587 \\ \text { E25 } & \text { B535-105 } & 2.86 & 2.18 & 29 & 1.57 & 1017 & 508 \\ \text { E26 } & \text { B535-209 } & 3.05 & 0.94 & 799 & 3.75 & 697 & 376 \\ \text { E27 } & \text { B537-40.3 } & 2.84 & 1.08 & 553 & 0.49 & 759 & 442 \\ \text { E28 } & \text { B538-91 } & 3.08 & 1.65 & 28 & 0.88 & 879 & 474 \\ \text { E29 } & \text { B555-70 } & 3.08 & 0.92 & 687 & 1.36 & 1086 & 553 \\ \text { E30 } & \text { B555-119.5 } & 3.07 & 1.28 & 568 & 1.55 & 1095 & 465 \\ \text { E31 } & \text { B561-71.7 } & 2.82 & 1.35 & 38 & 1.00 & 1262 & 537 \\ \text { E32 } & \text { B561-90 } & 2.75 & 1.29 & 29 & 0.75 & 1085 & 426 \\ \text { E33 } & \text { B561-123.5 } & 2.80 & 1.56 & 27 & 0.81 & 964 & 479 \\ \text { E34 } & \text { B562-74.3 } & 2.42 & 1.13 & 30 & 1.70 & 834 & 505 \\ \text { E35 } & \text { B562-198.5 } & 2.84 & 1.93 & 39 & 2.96 & 1094 & 471 \\ \text { E36 } & \text { B565-63 } & 3.35 & 0.94 & 22 & 1.08 & 1172 & 553 \\ \text { E37 } & \text { B565-154 } & 2.96 & & & 1.06 & 699 & 379 \\ \text { A14T } & \text { MB88-186 } & 3.10 & & & & 895 & 385 \\ \text { A15T } & \text { MB88-190 } & 2.78 & & & 1.22 & 750 & 229 \\ \text { A16T } & 92 T B-5 & 2.43 & & & 0.95 & 480 & 240\end{array}$




$\begin{array}{llrrrrrr}\text { Irrad. } & \text { Sample } & & & & \\ \text { Number } & \text { Number } & \text { Fe\% } & \text { SC } & \text { Cr } & \text { Co } & \text { Zr } & \text { HA } \\ \text { E21 } & \text { B13-76.2 } & 6.58 & 17.4 & 355 & 41 & 173 & 4.35 \\ \text { E22 } & \text { B13-104.7 } & 6.48 & 17.0 & 300 & 38 & 218 & 3.97 \\ \text { E23 } & \text { B13-155 } & 6.39 & 20.4 & 199 & 34 & 95 & 3.55 \\ \text { E24 } & \text { B19-46 } & 6.53 & 16.5 & 224 & 32 & 153 & 4.41 \\ \text { E25 } & \text { B535-105 } & 6.32 & 17.8 & 267 & 37 & 96 & 3.82 \\ \text { E26 } & \text { B535-209 } & 6.68 & 21.7 & 215 & 36 & 157 & 3.78 \\ \text { E27 } & \text { B537-40.3 } & 6.82 & 22.7 & 218 & 36 & 165 & 3.87 \\ \text { E28 } & \text { B538-91 } & 6.31 & 19.8 & 203 & 30 & 143 & 4.24 \\ \text { E29 } & \text { B555-70 } & 6.76 & 21.8 & 192 & 35 & 148 & 3.75 \\ \text { E30 } & \text { B555-119.5 } & 6.61 & 21.8 & 198 & 34 & 184 & 3.99 \\ \text { E31 } & \text { B561-71.7 } & 6.78 & 18.9 & 329 & 42 & 202 & 4.62 \\ \text { E32 } & \text { B561-90 } & 6.78 & 18.9 & 342 & 40 & 135 & 4.36 \\ \text { E33 } & \text { B561-123.5 } & 6.48 & 17.8 & 331 & 39 & 130 & 3.93 \\ \text { E34 } & \text { B562-74.3 } & 6.62 & 18.9 & 278 & 38 & 172 & 3.77 \\ \text { E35 } & \text { B562-198.5 } & 6.45 & 18.4 & 318 & 40 & 203 & 3.90 \\ \text { E36 } & \text { B565-63 } & 6.64 & 17.7 & 234 & 37 & 109 & 4.14 \\ \text { E37 } & \text { B565-154 } & 6.79 & 26.6 & 198 & 38 & & 3.37 \\ \text { A14T } & \text { MB88-186 } & 5.15 & 20.7 & 294 & 31 & 245 & 2.75 \\ \text { A15T } & \text { MB88-190 } & 4.19 & 17.1 & 218 & 25 & 140 & 2.15 \\ \text { A16T } & \text { 92TB-5 } & 7.07 & 24.4 & 223 & 41 & 218 & 2.28\end{array}$




$\begin{array}{llrrrrrr}\text { Irrad. } & \text { Sample } & & & & \\ \text { Number } & \text { Number } & \text { Ta } & \text { Th } & \text { U } & \text { Zn } & \text { As } & \text { Sb } \\ \text { E21 } & \text { B13-76.2 } & 7.15 & 4.0 & 14.8 & 85 & 1.1 & 8.6 \\ \text { E22 } & \text { B13-104.7 } & 6.65 & 3.6 & 1.8 & 104 & 42.4 & 7.8 \\ \text { E23 } & \text { B13-155 } & 7.89 & 1.5 & 9.5 & 96 & 82.4 & 7.9 \\ \text { E24 } & \text { B19-46 } & 5.94 & 2.1 & 2.6 & 104 & 23.8 & 5.5 \\ \text { E25 } & \text { B535-105 } & 6.17 & 3.7 & 1.0 & 91 & 196.8 & 6.8 \\ \text { E26 } & \text { B535-209 } & 6.94 & 1.5 & 12.5 & 102 & 36.4 & 7.9 \\ \text { E27 } & \text { B537-40.3 } & 7.03 & 1.5 & 17.7 & 120 & 112.5 & 5.8 \\ \text { E28 } & \text { B538-91 } & 0.54 & 1.8 & 1.5 & 101 & 63.7 & 12.0 \\ \text { E29 } & \text { B555-70 } & 8.44 & 1.6 & 11.8 & 118 & & 8.1 \\ \text { E30 } & \text { B555-119.5 } & 7.60 & 1.6 & & 99 & 11.4 & 2.1 \\ \text { E31 } & \text { B561-71.7 } & 6.42 & 4.7 & 20.1 & 103 & 85.7 & 2.8 \\ \text { E32 } & \text { B561-90 } & 6.58 & 3.9 & 8.3 & 105 & 39.6 & 8.6 \\ \text { E33 } & \text { B561-123.5 } & 6.12 & 3.4 & 10.3 & 103 & 23.2 & 6.2 \\ \text { E34 } & \text { B562-74.3 } & 6.56 & 3.8 & 2.9 & 109 & 35.1 & 7.1 \\ \text { E35 } & \text { B562-198.5 } & 5.64 & 3.5 & 9.1 & 95 & 70.7 & 6.8 \\ \text { E36 } & \text { B565-63 } & 4.08 & 3.0 & 6.8 & 94 & 99.1 & \\ \text { E37 } & \text { B565-154 } & 3.59 & 1.7 & 11.6 & 124 & 22.9 & \\ \text { A14T } & \text { MB88-186 } & 0.52 & 2.0 & 6.1 & 84 & 45.1 & 3.6 \\ \text { A15T } & \text { MB88-190 } & 0.34 & 1.9 & 1.5 & 75 & & \\ \text { A16T } & 92 T B-5 & 0.40 & 1.1 & 4.5 & 100 & 34.9 & 2.0\end{array}$


Irrad. Sample

$\begin{array}{llrrrrrr}\text { Number } & \text { Number } & \text { La } & \text { Ce } & \text { Nd } & \text { Sm } & \text { Eu } & \text { Tb } \\ \text { E21 } & \text { B13-76.2 } & 2.7 & 58.9 & 35 & 5.91 & 1.82 & 1.02 \\ \text { E22 } & \text { B13-104.7 } & 26.9 & 59.2 & 40 & 5.67 & 1.79 & 0.69 \\ \text { E23 } & \text { B13-155 } & 17.0 & 34.2 & 19 & 4.49 & 1.48 & 0.59 \\ \text { E24 } & \text { B19-46 } & 19.5 & 42.7 & 22 & 5.07 & 1.91 & 0.82 \\ \text { E25 } & \text { B535-105 } & 27.9 & 59.6 & 4 & 5.86 & 1.82 & 0.64 \\ \text { E26 } & \text { B535-209 } & 16.4 & 35.2 & 25 & 4.51 & 1.64 & 0.68 \\ \text { E27 } & \text { B537-40.3 } & 19.7 & 36.4 & 28 & 4.95 & 1.71 & 0.72 \\ \text { E28 } & \text { B538-91 } & 19.6 & 41.4 & 25 & 5.21 & 1.80 & 0.67 \\ \text { E29 } & \text { B555-70 } & 17.9 & 36.1 & 4 & 4.65 & 1.64 & 0.72 \\ \text { E30 } & \text { B555-119.5 } & 17.3 & 36.2 & 20 & 4.65 & 1.65 & 0.61 \\ \text { E31 } & \text { B561-71.7 } & 28.0 & 62.5 & 38 & 6.02 & 1.93 & 1.03 \\ \text { E32 } & \text { B561-90 } & 29.3 & 63.7 & 33 & 6.38 & 1.82 & 0.67 \\ \text { E33 } & \text { B561-123.5 } & 26.4 & 56.9 & 31 & 5.57 & 1.81 & 0.59 \\ \text { E34 } & \text { B562-74.3 } & 30.3 & 61.9 & 46 & 6.42 & 1.97 & 0.68 \\ \text { E35 } & \text { B562-198.5 } & 27.0 & 60.1 & 32 & 5.74 & 1.87 & 0.69 \\ \text { E36 } & \text { B565-63 } & 31.4 & 67.7 & 38 & 6.65 & 2.08 & 0.69 \\ \text { E37 } & \text { B565-154 } & 16.9 & 35.9 & & 4.48 & 1.68 & 0.67 \\ \text { A14T } & \text { MB88-186 } & 21.3 & 42.4 & 46 & 4.32 & 1.39 & 0.54 \\ \text { A15T } & \text { MB88-190 } & 14.0 & 20.8 & & 3.00 & 1.06 & 0.47 \\ \text { A16T } & 92 T B-5 & 8.9 & 17.8 & & 2.84 & 1.13 & 0.55\end{array}$


Irrad. Sample

$\begin{array}{llrr}\text { Number } & \text { Number } & \text { Yb } & \text { Lu } \\ \text { E21 } & \text { B13-76.2 } & 1.62 & 0.25 \\ \text { E22 } & \text { B13-104.7 } & 1.44 & 0.34 \\ \text { E23 } & \text { B13-155 } & 1.90 & 0.35 \\ \text { E24 } & \text { B19-46 } & 1.80 & 0.25 \\ \text { E25 } & \text { B535-105 } & 1.63 & 0.25 \\ \text { E26 } & \text { B535-209 } & 1.97 & 0.32 \\ \text { E27 } & \text { B537-40.3 } & 2.33 & 0.30 \\ \text { E28 } & \text { B538-91 } & 1.67 & 0.32 \\ \text { E29 } & \text { B555-70 } & 2.02 & 0.41 \\ \text { E30 } & \text { B555-119.5 } & 2.17 & 0.36 \\ \text { E31 } & \text { B561-71.7 } & 1.94 & 0.29 \\ \text { E32 } & \text { B561-90 } & 1.47 & 0.26 \\ \text { E33 } & \text { B561-123.5 } & 1.54 & 0.30 \\ \text { E34 } & \text { B562-74.3 } & 1.64 & 0.31 \\ \text { E35 } & \text { B562-198.5 } & 1.83 & 0.28 \\ \text { E36 } & \text { B565-63 } & 1.54 & 0.23 \\ \text { E37 } & \text { B565-154 } & 2.13 & 0.37 \\ \text { A14T } & \text { MB88-186 } & 1.55 & 0.28 \\ \text { A15T } & \text { MB88-190 } & 1.19 & 0.23 \\ \text { A16T } & 92 T B-5 & 1.86 & 0.33\end{array}$


APPENDIX B

GEOCHEMICAL DATA FOR SHALLOW SEDIMENT AND OTHER MISCELLANEOUS SAMPLES 
SHALLOW DRILL HOLE SEDIMENTS AND MISCELLANEOUS SAMPLES -IRRADIATIONS 93D, 93G, AND 94A

Samples collected from Trimet drill core, DOGAMI shallow drill holes, David's Hill Well, several volcanic ash samples, and standard driliing mud.

* Concentrations in ppm except $\mathrm{Na}, \mathrm{K}$, and $\mathrm{Fe}$

Irrad. Sample

\begin{tabular}{|c|c|c|c|c|c|c|c|}
\hline Number & Number & $\mathrm{Na} \%$ & $\mathrm{~K} \%$ & $\mathrm{Rb}$ & Cs & Sr & $\mathrm{Ba}$ \\
\hline D18 & b563-152 & 1.27 & 1.78 & 80 & 2.88 & 192 & 582 \\
\hline D19 & b563-172.2 & 3.27 & 0.13 & & & & 451 \\
\hline D20 & b563-212 & 3.85 & 0.70 & & 1.11 & 577 & \\
\hline D21 & b563-259 & 0.09 & 0.44 & 51 & 3.56 & 422 & \\
\hline $\mathrm{D} 22$ & b561-172 & 2.64 & 0.66 & & & 881 & 313 \\
\hline D23 & b561-135 & 1.97 & 0.91 & 18 & 1.59 & 921 & 296 \\
\hline D24 & b561-222 & 1.13 & 1.24 & 71 & 2.68 & 321 & 553 \\
\hline D2 5 & b557-114 & 1.33 & 1.14 & 76 & 3.09 & 310 & 595 \\
\hline D26 & b557-211 & 2.77 & 0.89 & 271 & 21.18 & 1163 & 531 \\
\hline D27 & b557-213 & 2.67 & 1.22 & & & 1040 & 546 \\
\hline $\mathrm{D} 28$ & b540-16I & 1.19 & 1.17 & 70 & 3.36 & 240 & 618 \\
\hline D29 & b541-54 & 1.53 & 1.56 & 51 & 2.64 & 301 & 608 \\
\hline D30 & b538-128 & 1.40 & 1.76 & 72 & 3.19 & 276 & 639 \\
\hline D31 & b538-148 & 0.78 & 1.09 & 73 & 2.30 & 206 & 559 \\
\hline D32 & b539-121 & 1.69 & 1.19 & 58 & 2.22 & 418 & 539 \\
\hline D33 & b539-146 & 0.69 & 0.97 & 58 & 2.66 & 162 & 439 \\
\hline D34 & b5 $54-241$ & 1.17 & 1.45 & 72 & 2.60 & 621 & \\
\hline D35 & b564-26I & 1.35 & 1.53 & 57 & 2.90 & 285 & 607 \\
\hline D36 & b5 $64-286$ & 1.61 & 1.71 & 77 & 3.06 & 281 & 671 \\
\hline GI & B535-12 & 1.11 & 1.37 & 51 & 3.36 & 311 & 564 \\
\hline $\mathrm{G} 2$ & B535-280. 2 & 1.75 & 2.11 & 64 & 2.40 & 285 & 659 \\
\hline G3 & B562-19.6 & 1.25 & 1.87 & 81 & 3.41 & 299 & 663 \\
\hline G4 & B563-159 & 1.32 & 2.31 & 78 & 3.63 & 220 & 662 \\
\hline G5 & B563-169 & 1.35 & 2.13 & 71 & 3.50 & 171 & 549 \\
\hline G6 & B564-38 & 1.37 & 1.64 & 54 & 3.51 & 352 & 556 \\
\hline G7 & B565-170 & 1.17 & 1.56 & 85 & 3.27 & 291 & 516 \\
\hline G8 & B565-205 & 1.13 & 1.50 & 62 & 1.86 & 183 & 599 \\
\hline G9 & B565-214 & 1.22 & 1.84 & 76 & 3.38 & 257 & 666 \\
\hline GIO & B $565-226$ & 0.29 & 0.40 & 49 & 1.29 & 642 & 531 \\
\hline A24 & BVD2 -93.5 & 2.54 & 1.03 & 35 & 1.71 & 316 & 456 \\
\hline A2 5 & BVD3 - 19.8 & 1.85 & 1.81 & 65 & 3.36 & 367 & 670 \\
\hline A26 & BVD4 -36.5 & 0.35 & 0.82 & 67 & 3.88 & 614 & \\
\hline A2 7 & BVD4 -59.9 & 0.11 & 0.35 & 40 & 3.89 & 277 & 256 \\
\hline A2 8 & BVD4 - 91.4 & 0.76 & 1.85 & 77 & 5.62 & 588 & \\
\hline A29 & BVD5 - 55 & 1.90 & 1.98 & 83 & 4.38 & 359 & 722 \\
\hline A30 & BVD6-25 & 2.33 & 1.57 & 46 & 1. 82 & 452 & 610 \\
\hline A3 1 & BVD6 - 47 & 1.36 & 1.24 & 42 & 3.06 & 493 & 653 \\
\hline A32 & GSD2 - 10-15 & 2.26 & 1.27 & 43 & 2.47 & 411 & 634 \\
\hline A33 & GSD3 $-35-65$ & 1.09 & 2.13 & 86 & 5.45 & 274 & 721 \\
\hline A 34 & GSD5-75-95 & 2.66 & 1.48 & 41 & 1.82 & 502 & 568 \\
\hline
\end{tabular}




\begin{tabular}{|c|c|c|c|c|c|c|c|}
\hline Irrad. & Sample & & & & & & \\
\hline Number & Number & $\mathrm{Fe} \%$ & $S C$ & $\mathrm{Cr}$ & Co & $\mathrm{Zr}$ & $\mathrm{HF}$ \\
\hline D18 & b563-152 & 3.71 & 12.7 & 52 & 11 & 231 & 8.03 \\
\hline D19 & b5 $53-172.2$ & 12.06 & 57.4 & 42 & 46 & & 5.07 \\
\hline D2 0 & b563-212 & 12.20 & 45.3 & 56 & 31 & 220 & 5.56 \\
\hline D21 & b5 $63-259$ & 12.23 & 43.4 & 59 & 41 & 528 & 8.39 \\
\hline 22 & $b 561-172$ & 6.43 & 24.2 & 178 & 34 & 258 & 3.72 \\
\hline D23 & b561-135 & 5.70 & 18.8 & 255 & 32 & 231 & 3.34 \\
\hline D24 & b5 $561-222$ & 4.63 & 16.0 & 70 & 7 & 272 & 6.74 \\
\hline D2 5 & b557-114 & 4.05 & 11.3 & 83 & 22 & 201 & 7.90 \\
\hline D2 6 & b557-211 & 6.35 & 17.4 & 224 & 33 & & 3.43 \\
\hline D2 7 & b557-213 & 6.21 & 16.3 & 231 & 32 & & 3.88 \\
\hline D2 8 & b540-161 & 5.17 & 12.8 & 145 & 21 & 319 & 7.35 \\
\hline 29 & b541-54 & 3.01 & 8.8 & 64 & 13 & 308 & 7.48 \\
\hline D30 & b5 $38-128$ & 3.65 & 12.5 & 71 & 14 & 227 & 8.03 \\
\hline D31 & b538-148 & 5.63 & 17.0 & 136 & 25 & 282 & 6.52 \\
\hline D32 & b539-121 & 4.80 & 15.1 & 108 & 29 & & 6.31 \\
\hline D33 & b539-146 & 5.34 & 16.5 & 87 & 19 & 220 & 6.38 \\
\hline D34 & b5 $54-241$ & 3.35 & 11.5 & 85 & 23 & 264 & 8.52 \\
\hline D35 & b564-261 & 3.32 & 10.7 & 74 & 13 & 448 & 16.98 \\
\hline D36 & b564-286 & 2.81 & 9.8 & 72 & 10 & 308 & 8.43 \\
\hline $\mathrm{Gl}$ & B535-12 & 4.78 & 16.8 & 87 & 9 & 172 & 6.64 \\
\hline G2 & B535-280.2 & 2.58 & 10.9 & 66 & 9 & 154 & 9.92 \\
\hline G3 & B562-19.6 & 4.37 & 16.0 & 75 & 14 & 212 & 8.54 \\
\hline G4 & B563-159 & 4.71 & 17.0 & 55 & 21 & 219 & 9.10 \\
\hline G5 & B563-169 & 2.22 & 13.1 & 68 & 7 & 170 & 8.45 \\
\hline G6 & B5 $64-38$ & 4.24 & 15.0 & 80 & 15 & 217 & 9.83 \\
\hline G7 & B $565-170$ & 2.26 & 15.8 & 79 & 12 & 205 & 9.13 \\
\hline G8 & B565-205 & 5.54 & 18.9 & 65 & 22 & 364 & 19.93 \\
\hline G9 & B565-214 & 4.40 & 16.1 & 64 & 18 & 196 & 6.62 \\
\hline GIO & $B 565-226$ & 10.47 & 55.5 & 26 & 35 & 415 & 8.97 \\
\hline A24 & BVD2 -93.5 & 4.20 & 17.4 & 164 & 21 & 127 & 4.66 \\
\hline A2 5 & BVD3-19.8 & 5.50 & 17.2 & 134 & 19 & 335 & 7.39 \\
\hline A2 6 & BVD4 -36.5 & 10.39 & 37.3 & 70 & 30 & 407 & 8.31 \\
\hline A2 7 & BVD4 - 59.9 & 6.42 & 22.4 & 71 & 12 & 340 & 4.44 \\
\hline A2 8 & BVD4 - 91.4 & 3.82 & 14.2 & 39 & 14 & 298 & 5.87 \\
\hline A2 & BVD $5-55$ & 4.06 & 14.8 & 90 & 17 & 183 & 7.07 \\
\hline & BVD $6-25$ & 4.64 & 13.8 & 64 & 18 & 198 & 4.68 \\
\hline & BVD $6-47$ & 5.04 & 20.1 & 82 & 22 & 319 & 6.72 \\
\hline A32 & GSD2-10-15 & 5.14 & 18.4 & 64 & 24 & 149 & 4.22 \\
\hline A33 & GSD3-35-65 & 5.01 & 18.0 & 80 & 21 & 261 & 5.10 \\
\hline A 34 & GSD5-75-95 & 6.18 & 18.6 & 64 & 27 & 328 & 4.14 \\
\hline
\end{tabular}




\begin{tabular}{|c|c|c|c|c|c|c|c|}
\hline $\begin{array}{l}\text { Irrad. } \\
\text { Number }\end{array}$ & $\begin{array}{l}\text { Sample } \\
\text { Number }\end{array}$ & $\mathrm{Ta}$ & Th & $\mathrm{U}$ & $\mathrm{Zn}$ & As & $\mathrm{Sb}$ \\
\hline D18 & b563-152 & 0.97 & 10.2 & 3.0 & 68 & 5.8 & 1.4 \\
\hline D19 & b563-172. 2 & 0.86 & 4.4 & 1.9 & 221 & 28.0 & 1.8 \\
\hline $\mathrm{D} 20$ & b563-212 & 0.93 & 4.4 & 1.2 & 229 & & \\
\hline D21 & b5 $563-259$ & 1.50 & 9.7 & 2.8 & 179 & 4.3 & 7.9 \\
\hline D22 & b561-172 & 0.53 & 2.6 & 10.6 & 106 & 45.3 & \\
\hline D23 & b561-135 & 0.67 & 3.4 & 2.1 & 84 & 6.4 & 12.0 \\
\hline D24 & b5 $51-222$ & 0.91 & 8.5 & 3.0 & 67 & 4.2 & \\
\hline D25 & b557-114 & 0.82 & 8.7 & 2.5 & 63 & 6.6 & 8.3 \\
\hline D26 & b557-211 & 0.62 & 2.6 & 1.2 & 93 & 85.7 & 2.8 \\
\hline D27 & b557-213 & 0.67 & 2.7 & & 83 & & \\
\hline D28 & b540-161 & 0.90 & 8.9 & 2.7 & 77 & 5.4 & \\
\hline D2 9 & b541-54 & 0.95 & 8.8 & 0.7 & 38 & 5.6 & 7.1 \\
\hline D30 & b538-128 & 0.88 & 10.8 & 2.8 & 72 & 5.6 & \\
\hline D31 & b538-148 & 0.97 & 8.3 & 2.9 & 111 & 3.9 & \\
\hline D32 & b539-121 & 0.86 & 8.5 & & 134 & 7.1 & \\
\hline D33 & b539-146 & 0.90 & 8.2 & 2.5 & 79 & 6.0 & 1.1 \\
\hline D34 & b564-241 & 0.96 & 9.6 & 2.8 & 55 & 4.4 & \\
\hline D35 & b5 $64-261$ & 1.22 & 15.8 & 4.2 & 52 & 7.0 & 0.8 \\
\hline D3 6 & b5 $54-286$ & 1.02 & 10.9 & & 59 & 1.3 & \\
\hline G1 & B535-12 & 0.65 & 10.8 & 3.3 & 76 & 8.7 & 1.0 \\
\hline $\mathrm{G} 2$ & B535-280.2 & 0.57 & 10.4 & 4.2 & 55 & 10.3 & 1.3 \\
\hline G3 & B562-19.6 & 0.75 & 12.8 & 2.8 & 242 & 8.8 & 1.0 \\
\hline G4 & B563-159 & 0.78 & 10.7 & 3.2 & 81 & 6.2 & 1.3 \\
\hline G5 & B563-169 & 0.54 & 11.6 & 2.9 & 68 & & 0.5 \\
\hline G6 & B564-38 & 0.52 & 11.9 & 3.8 & 70 & 9.8 & \\
\hline G7 & B565-170 & 0.62 & 10.5 & 2.9 & 88 & 2.3 & 0.8 \\
\hline G8 & B565-205 & 0.62 & 17.0 & 5.2 & 88 & 5.8 & 0.8 \\
\hline G9 & B565-214 & 0.58 & 11.0 & 3.6 & 81 & 5.9 & 1.2 \\
\hline G10 & B565-226 & 1.61 & 7.9 & 3.3 & 211 & 2.3 & \\
\hline A24 & BVD2 -93.5 & 0.56 & 4.5 & 1.6 & 85 & 8.7 & 0.8 \\
\hline A2 5 & BVD3-19.8 & 1.12 & 9.3 & 2.2 & 95 & 16.0 & 1.0 \\
\hline A2 6 & BVD4 -36.5 & 1.33 & 11.8 & 4.2 & 145 & 14.8 & \\
\hline A 27 & BVD4 -59.9 & 0.84 & 6.0 & 1.9 & 99 & 3.4 & 0.7 \\
\hline A2 8 & BVD4 -91.4 & 2.27 & 17.7 & 5.0 & 106 & 2.0 & 1.1 \\
\hline A29 & BVD5-55 & 1.21 & 11.0 & 4.3 & 80 & 10.6 & 1.4 \\
\hline A30 & BVD $6-25$ & 0.63 & 4.9 & 2.1 & 75 & 4.9 & 0.5 \\
\hline A 31 & BVD $6-47$ & 1.12 & 6.7 & 2.3 & 102 & 8.0 & \\
\hline A32 & GSD2 - 10-15 & 0.58 & 4.9 & 0.7 & 86 & 9.4 & 1.6 \\
\hline A33 & GSD3 $-35-65$ & 1.15 & 11.7 & 4.0 & 119 & 8.6 & 2.5 \\
\hline A34 & GSD5-75-95 & 0.72 & 4.9 & 1.2 & 97 & 3.2 & 1.5 \\
\hline
\end{tabular}




\begin{tabular}{|c|c|c|c|c|c|c|c|}
\hline $\begin{array}{l}\text { Irrad. } \\
\text { Number }\end{array}$ & $\begin{array}{l}\text { Sample } \\
\text { Number }\end{array}$ & La & $\mathrm{Ce}$ & $\mathrm{Nd}$ & $\mathrm{Sm}$ & Eu & $\mathrm{Tb}$ \\
\hline D18 & b563-152 & 38.2 & 70.9 & 35 & 6.19 & 1.35 & 0.86 \\
\hline D19 & b563-172.2 & 31.4 & 56.2 & & 10.42 & 3.05 & 1.64 \\
\hline $\mathrm{D} 20$ & b563-212 & 51.6 & 30.8 & & 9.73 & 3.07 & 1.41 \\
\hline D2I & b563-259 & 48.9 & 95.1 & 50 & 10.02 & 2.68 & \\
\hline $\mathrm{D} 22$ & b56I-172 & 19.1 & 39.5 & 27 & 4.94 & 1.75 & \\
\hline $\mathrm{D} 23$ & b56I-135 & 19.4 & 42.4 & & 4.54 & 1.30 & 0.54 \\
\hline D24 & b561-222 & 26.7 & 47.5 & 28 & 4.60 & 1.13 & 0.69 \\
\hline D2 5 & b557-114 & 34.6 & 68.3 & 30 & 5.49 & 1.29 & 0.77 \\
\hline D2 6 & b557-211 & 32.3 & 62.2 & 40 & 7.23 & 2.18 & 0.79 \\
\hline $\mathrm{D} 27$ & b557-213 & 31.3 & 61.0 & & 6.60 & 2.02 & 0.65 \\
\hline $\mathrm{D} 28$ & b540-161 & 37.1 & 67.2 & & 5.86 & 1.55 & 0.91 \\
\hline D29 & b5 $541-54$ & 36.5 & 65.7 & 32 & 5.51 & 1.27 & 0.82 \\
\hline D30 & b5 $38-128$ & 41.3 & 78.0 & 40 & 6.40 & 1.48 & 0.91 \\
\hline D31 & b5 $38-148$ & 34.4 & 73.0 & 50 & 6.06 & 1.53 & 0.79 \\
\hline D32 & b539-121 & 40.1 & 71.8 & 47 & 7.14 & 1.81 & 0.96 \\
\hline D33 & b539-146 & 22.1 & 54.8 & 33 & 3.75 & 0.92 & 0.78 \\
\hline D34 & b5 $54-241$ & 37.7 & 69.5 & 29 & 5.65 & 1.30 & 0.81 \\
\hline D35 & b5 $54-261$ & 59.1 & 117.1 & 46 & 8.84 & 1.81 & 1.14 \\
\hline D36 & b5 $54-286$ & 41.9 & 73.7 & 34 & 6.38 & 1.37 & 0.87 \\
\hline GI & B535-12 & 33.3 & 69.5 & & 5.75 & 1.38 & 0.74 \\
\hline G2 & B535-280.2 & 46.6 & 81.8 & & 7.29 & 1.42 & 0.87 \\
\hline G3 & B562-19.6 & 47.5 & 87.0 & 42 & 7.85 & 1.75 & 1.04 \\
\hline G4 & B563-159 & 40.2 & 85.8 & & 7.03 & 1.69 & 0.95 \\
\hline G5 & B563-169 & 49.1 & 82.8 & 35 & 7.75 & 1.56 & 1.00 \\
\hline G6 & B564-38 & 41.0 & 82.9 & & 6.48 & 1.47 & 0.92 \\
\hline G7 & B5 $65-170$ & 43.2 & 81.4 & 35 & 6.61 & 1.39 & 0.83 \\
\hline G8 & B565-205 & 69.3 & 119.2 & 55 & 11.25 & 2.14 & 1.39 \\
\hline G9 & B5 $65-214$ & 41.7 & 78.4 & 40 & 7.18 & 1.61 & 0.97 \\
\hline G10 & B565-226 & 38.2 & 159.2 & 52 & 13.59 & 3.76 & 1.65 \\
\hline A 24 & BVD2 -93.5 & 20.7 & 38.4 & 24 & 4.21 & 1.11 & 0.67 \\
\hline A25 & BVD3 - 19.8 & 35.8 & 69.1 & & 6.32 & 1.51 & 0.94 \\
\hline A26 & BVD4 -36.5 & 40.5 & 82.6 & & 8.68 & 2.32 & 1.80 \\
\hline A2 7 & BVD $4-59.9$ & 13.5 & 22.6 & & 2.20 & 0.65 & 0.49 \\
\hline A2 8 & BVD4 -91.4 & 31.9 & 64.8 & 29 & 6.54 & 1.20 & 1.14 \\
\hline A29 & BVD5 - 55 & 40.4 & 78.4 & & 6.73 & 1.56 & 0.98 \\
\hline A30 & BVD $6-25$ & 23.0 & 44.4 & & 4.29 & 1.22 & 0.66 \\
\hline A31 & BVD6 -47 & 31.4 & 58.1 & 29 & 6.37 & 1.62 & 0.94 \\
\hline A32 & GSD2 - $10-15$ & 24.4 & 46.0 & 28 & 5.59 & 1.66 & 0.80 \\
\hline A33 & GSD $3-35-65$ & 38.9 & 79.7 & 41 & 7.29 & 1.68 & 1.10 \\
\hline A34 & GSD5-75-95 & 24.4 & 50.4 & & 5.18 & 1.63 & 0.8 \\
\hline
\end{tabular}


Irrad. Sample

$\begin{array}{llll}\text { Number } & \text { Number } & \text { Yb } & \text { Lu } \\ \text { D18 } & \text { b563-152 } & 2.86 & 0.44 \\ \text { D19 } & \text { b563-172.2 } & 7.67 & 1.14 \\ \text { D20 } & \text { b563-212 } & 4.56 & 0.64 \\ \text { D21 } & \text { b563-259 } & 3.41 & 0.53 \\ \text { D22 } & \text { b561-172 } & 2.32 & 0.38 \\ \text { D23 } & \text { b561-135 } & 1.32 & 0.22 \\ \text { D24 } & \text { b561-222 } & 2.45 & 0.35 \\ \text { D25 } & \text { b557-114 } & 2.40 & 0.37 \\ \text { D26 } & \text { b557-211 } & 1.81 & 0.24 \\ \text { D27 } & \text { b557-213 } & 1.78 & 0.22 \\ \text { D28 } & \text { b540-161 } & 3.04 & 0.48 \\ \text { D29 } & \text { b541-54 } & 2.35 & 0.34 \\ \text { D30 } & \text { b538-128 } & 2.68 & 0.42 \\ \text { D31 } & \text { b538-148 } & 2.65 & 0.37 \\ \text { D32 } & \text { b539-121 } & 2.53 & 0.39 \\ \text { D33 } & \text { b539-146 } & 1.95 & 0.32 \\ \text { D34 } & \text { b564-241 } & 2.46 & 0.37 \\ \text { D35 } & \text { b564-261 } & 4.29 & 0.56 \\ \text { D36 } & \text { b564-286 } & 2.76 & 0.38 \\ \text { G1 } & \text { B535-12 } & 2.32 & 0.44 \\ \text { G2 } & \text { B535-280.2 } & 2.90 & 0.51 \\ \text { G3 } & \text { B562-19.6 } & 3.09 & 0.54 \\ \text { G4 } & \text { B563-159 } & 2.95 & 0.56 \\ \text { G5 } & \text { B563-169 } & 3.10 & 0.49 \\ \text { G6 } & \text { B564-38 } & 2.89 & 0.54 \\ \text { G7 } & \text { B565-170 } & 2.53 & 0.49 \\ \text { G8 } & \text { B565-205 } & 4.55 & 0.79 \\ \text { G9 } & \text { B565-214 } & 3.04 & 0.56 \\ \text { G10 } & \text { B565-226 } & 3.74 & 0.68 \\ \text { A24 } & \text { BVD2-93.5 } & 2.22 & 0.34 \\ \text { A25 } & \text { BVD3-19.8 } & 2.86 & 0.42 \\ \text { A26 } & \text { BVD4-36.5 } & 3.50 & 0.59 \\ \text { A27 } & \text { BVD4-59.9 } & 1.67 & 0.26 \\ \text { A28 } & \text { BVD4-91.4 } & 2.94 & 0.47 \\ \text { A29 } & \text { BVD5-55 } & 2.92 & 0.47 \\ \text { A30 } & \text { BVD6-25 } & 2.14 & 0.31 \\ \text { A31 } & \text { BVD6-47 } & 3.02 & 0.43 \\ \text { A32 } & \text { GSD2-10-15 } & 2.51 & 0.42 \\ \text { A33 } & \text { GSD3-35-65 } & 3.16 & 0.55 \\ \text { A34 } & \text { GSD5-75-95 } & 2.24 & 0.37 \\ & & & \end{array}$


Irrad. Sample

\begin{tabular}{|c|c|c|c|c|c|c|c|}
\hline Number & Number & $\mathrm{Na} \%$ & $\mathrm{~K} \%$ & $\mathrm{Rb}$ & Cs & $\mathrm{Sr}$ & $\mathrm{Ba}$ \\
\hline A35 & GSD5-195-215 & 1.33 & 1.62 & 82 & 4.02 & 244 & 722 \\
\hline A36 & Drill Mud & 1.57 & 0.59 & 16 & 0.73 & 284 & 316 \\
\hline $\mathrm{A} 1 \mathrm{~T}$ & LOD1-53 & 1.80 & 2.01 & 58 & 2.95 & 421 & 628 \\
\hline $\mathrm{A} 2 \mathrm{~T}$ & LOD3 - 22 & 1.61 & 1.88 & 71 & 3.99 & 300 & 576 \\
\hline A3T & LOD4 - 100 & 1.00 & 1.26 & 40 & 2.59 & 310 & 609 \\
\hline $\mathrm{A} 4 \mathrm{~T}$ & LOD5 - 29.6 & 1.49 & 2.73 & 94 & 6.99 & 234 & 674 \\
\hline A5T & LOD6 -95-110 & 0.11 & 0.26 & & & & \\
\hline $\mathrm{A} 6 \mathrm{~T}$ & LOD9 -41.7 & 1.38 & 1.26 & 48 & 2.89 & 389 & 683 \\
\hline A7T & LTD4-11.6 & 1.87 & 1.84 & 79 & 3.33 & 348 & 690 \\
\hline A8T & MTD2-145-155 & 2.23 & 2.03 & 60 & 1.95 & 324 & 656 \\
\hline A9T & MTD5-95-115 & 0.76 & 1.37 & 46 & 2.27 & 78 & 399 \\
\hline A10T & ORD1-19.6 & 1.63 & 3.46 & 123 & 2.30 & 269 & 700 \\
\hline $\mathrm{A} 11 \mathrm{~T}$ & VND1-25-30 & 2.33 & 2.13 & 59 & 1.82 & 323 & 592 \\
\hline $\mathrm{A} 12 \mathrm{~T}$ & $\mathrm{DHW}-330$ & 1.53 & 1.31 & 73 & 4.24 & 273 & 579 \\
\hline $\mathrm{A} 17 \mathrm{~T}$ & Sample \#7-JS & 3.38 & & 29 & 1.02 & 472 & 444 \\
\hline $\mathrm{A} 18 \mathrm{~T}$ & $S R-3-J S$ & 2.77 & & 31 & 2.16 & 376 & 533 \\
\hline MF & $\begin{array}{l}\text { LE-50 } \\
\text { Missoula }\end{array}$ & & & & & & \\
\hline & Floods & 1.60 & 1.70 & 57 & 2.70 & 380 & 540 \\
\hline BLUE & LE-186 & & & & & & \\
\hline & Willamette & & & & & & \\
\hline & Blue Mud & 0.59 & 1.40 & 44 & 3.50 & 110 & 390 \\
\hline & Portland & & & & & & \\
\hline & Hills Sil & 1.83 & 1.73 & 65 & 2.70 & 338 & 628 \\
\hline & Mudstone & 0.96 & 1.89 & 90 & 5.00 & 243 & 676 \\
\hline
\end{tabular}


Irrad. Sample

\begin{tabular}{|c|c|c|c|c|c|c|c|}
\hline Number & Number & $\mathrm{Fe} \%$ & $\mathrm{Sc}$ & $\mathrm{Cr}$ & Co & Zr & $\mathrm{Hf}$ \\
\hline A35 & GSD $-195-215$ & 5.56 & 15.6 & 114 & 17 & 408 & 6.48 \\
\hline A3 6 & Drill Mud & 3.10 & 5.0 & 4 & 1 & 155 & 6.11 \\
\hline $\mathrm{A} I \mathrm{~T}$ & LOD1 - 53 & 2.82 & 10.7 & 52 & 9 & 235 & 8.67 \\
\hline A2T & LOD3 - 22 & 5.53 & 11.9 & 53 & 12 & 310 & 5.92 \\
\hline $\mathrm{A} 3 \mathrm{~T}$ & LOD4 - 100 & 5.38 & 17.3 & 71 & 26 & 234 & 7.00 \\
\hline $\mathrm{A} 4 \mathrm{~T}$ & LOD5 - 29.6 & 3.77 & 14.5 & 63 & 16 & 148 & 4.78 \\
\hline $\mathrm{A} 5 \mathrm{~T}$ & LOD6 - 95-110 & & & & & & \\
\hline $\mathrm{A} 6 \mathrm{~T}$ & LOD9 -41.7 & 6.79 & 26.8 & 92 & 25 & 362 & 6.81 \\
\hline $\mathrm{A} 7 \mathrm{~T}$ & LTD4-11. 6 & 3.72 & 12.2 & 60 & 16 & 276 & 8.37 \\
\hline $\mathrm{A} 8 \mathrm{~T}$ & MTD2 - 145-155 & 3.29 & 10.9 & 42 & 14 & 141 & 3.40 \\
\hline A9T & MTD5-95-115 & 4.12 & 14.2 & 56 & 17 & 203 & 6.33 \\
\hline AIOT & ORDI - 19.6 & 3.62 & 12.5 & 46 & 16 & 236 & 4.24 \\
\hline $\mathrm{A} 11 \mathrm{~T}$ & VNDI $-25-30$ & 4.70 & 17.2 & 38 & 19 & 152 & $3.3 I$ \\
\hline $\mathrm{A} 12 \mathrm{~T}$ & $D H W-330$ & 4.34 & 15.7 & 59 & 13 & 224 & 5.58 \\
\hline $\mathrm{A}] 7 \mathrm{~T}$ & Sample \#7-JS & 2.26 & 8.0 & 23 & 9 & 227 & 3.90 \\
\hline $\mathrm{A} 18 \mathrm{~T}$ & $S R-3-J S$ & 2.57 & 9.1 & 22 & 10 & 97 & 4.3 \\
\hline $\mathrm{MF}$ & $L E-50$ & & & & & & \\
\hline & Missoula & 443 & 157 & 67 & 18 & 70 & \\
\hline BLUE & $\begin{array}{l}\text { LE- } 186 \\
\text { Willamette }\end{array}$ & 4.43 & $\perp J$ & $0 \perp$ & 10 & 210 & \\
\hline & Blue Mud & 4.50 & 18.9 & 72 & 9 & 140 & 3.8 \\
\hline PHS & Portland & & & & & & \\
\hline \multirow{3}{*}{ SRM } & Hills silt & 3.66 & 13.0 & 59 & 14 & & 8.7 \\
\hline & Sandy River & & & & & & \\
\hline & Mudstone & 4.08 & 16.4 & 76 & 19 & & 6.2 \\
\hline
\end{tabular}




\begin{tabular}{|c|c|c|c|c|c|c|c|}
\hline Irrad. & Sample & & & & & & \\
\hline Number & Number & $\mathrm{Ta}$ & Th & $\begin{array}{l}U \\
5\end{array}$ & $\begin{array}{l}\mathrm{Zn} \\
83\end{array}$ & $\begin{array}{r}\text { As } \\
7.1\end{array}$ & $\begin{array}{r}5 b \\
0.9\end{array}$ \\
\hline A3 5 & GSD5-195-215 & 1.01 & 9.8 & 2.5 & $\begin{array}{l}83 \\
58\end{array}$ & 10.6 & $\begin{array}{l}0.9 \\
1.1\end{array}$ \\
\hline A36 & Drill Mud & 3.62 & 36.5 & 16.9 & 58 & $\begin{array}{r}10.6 \\
4.1\end{array}$ & $1 \cdot \frac{1}{1}$ \\
\hline $\mathrm{A} I \mathrm{~T}$ & LODI - 53 & 0.97 & 11.8 & 2.4 & 61 & $\begin{array}{l}4 \cdot 1 \\
3 \cdot 3\end{array}$ & $1 \cdot 1$ \\
\hline $\mathrm{A} 2 \mathrm{~T}$ & IOD $3-22$ & 0.75 & 8.3 & 2.9 & 74 & 3.3 & 1.8 \\
\hline A3T & LOD4 - 100 & 0.81 & 7.5 & 3.9 & 74 & 5.0 & 1.2 \\
\hline $\mathrm{A} 4 \mathrm{~T}$ & LOD5 - 29.6 & 0.89 & 11.0 & 3.9 & 96 & 13.2 & 1.8 \\
\hline A5T & LOD6 - 95-110 & & & 1.3 & & 4.5 & \\
\hline $\mathrm{A} 6 \mathrm{~T}$ & LOD9-41.7 & 0.99 & 8.2 & 2.5 & 120 & 7.3 & \\
\hline $\mathrm{A} 7 \mathrm{~T}$ & LTD4-11. 6 & 0.96 & 9.7 & 2.7 & 76 & 7.1 & 0.7 \\
\hline A8T & MTD2-145-155 & 0.57 & 4.7 & 1.2 & 57 & 2.5 & 0.5 \\
\hline A9T & MTD5-95-115 & 0.99 & 9.1 & 2.4 & 61 & 7.4 & 0.6 \\
\hline A10T & ORD1-19.6 & 0.86 & 7.4 & 2.5 & 59 & 1.7 & \\
\hline $\mathrm{A} \perp 1 \mathrm{~T}$ & VND1-25-30 & 0.56 & 3.8 & 1.1 & 81 & 6.4 & 2.3 \\
\hline $\mathrm{A} 12 \mathrm{~T}$ & $\mathrm{DHW}-330$ & 0.81 & 7.9 & 2.6 & 88 & 10.9 & 2.8 \\
\hline $\mathrm{A} 17 \mathrm{~T}$ & Sample \#7-JS & 0.56 & 3.8 & 2.1 & 46 & 5.5 & \\
\hline A18T & SR-3-JS & 0.64 & 4.8 & 1.6 & 46 & 4.4 & 0.5 \\
\hline \multirow[t]{2}{*}{$\mathrm{MF}$} & LE- 50 & & & & & & \\
\hline & $\begin{array}{l}\text { Missoula } \\
\text { Floods }\end{array}$ & 0.78 & 7.8 & 2.6 & 82 & 9.3 & 1.1 \\
\hline \multirow[t]{2}{*}{ BLUE } & $L E-186$ & & & & & & \\
\hline & $\begin{array}{l}\text { Willamette } \\
\text { Blue Mud }\end{array}$ & & 5 & & & 67 & 080 \\
\hline PHS & Hills silt & 0.94 & 10.3 & & 70 & 6.0 & \\
\hline \multirow[t]{2}{*}{ SRM } & ly River & & & & & & \\
\hline & Mudstone & 1.15 & 11.8 & & 87 & 4.5 & \\
\hline
\end{tabular}


Irrad. Sample

Number Number

$\mathrm{La} \mathrm{Ce} \mathrm{Nd} \quad \mathrm{Sm} \quad \mathrm{Eu} \mathrm{Tb}$

A35

GSD5-195-215 32.6

68.4

5.18

1.27

0.76

A36

Drill Mud

45.1

87.3

$41 \quad 11.03$

0.68

1.72

$\mathrm{A} 1 \mathrm{~T}$

LOD1 -53

45.6

78.5

31

6.90

1.46

0.95

$\mathrm{A} 2 \mathrm{~T}$

LOD3 -22

30.4

57.0

5.23

1. 21

0.74

$\mathrm{A} 3 \mathrm{~T}$

LOD4 -100

39.9

75.5

38

1.97

1.09

$\mathrm{A} 4 \mathrm{~T}$

LOD5 -29.6

35.6

70.8

39

6.33

1.36

0.91

A5T

LOD6-95-110 36.0

65.4

10.99

$\mathrm{A} 6 \mathrm{~T}$

LOD9 -41.7

35.4

72.6

7.44

$2.07 \quad 1.09$

A7T

LTD4-11.6 38.1

38.7

33

5.87

1.39

0.83

A8T

MTD2-145-155 21.2

67.4

3.81

1.02

0.57

A9T

MTD5-95-115 29.5

52.1

$\mathrm{A} 10 \mathrm{~T}$

ORD1-19.6

27.9

26

4.72

1.00

0.64

Al1T

VND 1 - 25-30

35.6

4.45

1.20

0.63

22

4.25

1.22

0.67

DHW -330

28.4

54.9

5.92

1.36

0.83

A17T

Sample \#7-JS 21.4

35.4

3.62

1.04

0.47

A18T

SR-3-JS

23.2

45.0

21

4.29

1.07

0.58

MF

Missoula

Floods

32.0

61.0

5.67

1.35

0.78

BLUE

LE- 186

Willamette

Blue Mud

22.5

42.0

22

5.53

1.23

0.64

PHS

Portland

$6.50 \quad 1.36 \quad 1.06$

SRM

Hills Silt $37.9 \quad 78.0$

$\begin{array}{lll}7.70 & 1.53 \quad 1.14\end{array}$

Sandy River

Mudstone

$40.7 \quad 91.0$

1.53 
Irrad. Sample

\begin{tabular}{|c|c|c|c|}
\hline Number & Number & Yb & Lu \\
\hline A35 & GSD5-195-215 & 2.37 & 0.41 \\
\hline A3 6 & Drill Mud & 4.59 & 0.66 \\
\hline A1T & LOD1 - 53 & 2.94 & 0.49 \\
\hline $\mathrm{A} 2 \mathrm{~T}$ & LOD3 - 22 & 2.53 & 0.38 \\
\hline $\mathrm{A} 3 \mathrm{~T}$ & LOD4 - 100 & 3.60 & 0.57 \\
\hline $\mathrm{A} 4 \mathrm{~T}$ & LOD5 - 29.6 & 3.35 & 0.50 \\
\hline A5T & LOD6 - 95-110 & & \\
\hline A6T & LOD9 - 41.7 & 3.50 & 0.54 \\
\hline $\mathrm{A} 7 \mathrm{~T}$ & ITD4-11. 6 & 2.81 & 0.44 \\
\hline $\mathrm{A} 8 \mathrm{~T}$ & MTD2 - 145-155 & 1.74 & 0.33 \\
\hline A9T & MTD5-95-115 & 1.85 & 0.32 \\
\hline AIOT & ORDI-19.6 & 2.31 & 0.40 \\
\hline $\mathrm{A} 11 \mathrm{~T}$ & VND1-25-30 & 1.75 & 0.37 \\
\hline $\mathrm{A} 12 \mathrm{~T}$ & DHW-330 & 2.83 & 0.50 \\
\hline $\mathrm{A} 17 \mathrm{~T}$ & Sample \#7-JS & 1.72 & 0.24 \\
\hline $\mathrm{A} 18 \mathrm{~T}$ & SR-3-JS & 1.76 & 0.25 \\
\hline \multirow[t]{3}{*}{$\mathrm{MF}$} & $L E-50$ & & \\
\hline & Missoula & & \\
\hline & Floods & 2.50 & 0.4 \\
\hline \multirow[t]{3}{*}{ BLUE } & LE- 186 & & \\
\hline & Willamette & & \\
\hline & Blue Mud & 2.10 & 0.33 \\
\hline \multirow[t]{2}{*}{ PHS } & Portland & & \\
\hline & Hills silt & 2.63 & 0.5 \\
\hline \multirow[t]{2}{*}{ SRM } & Sandy River & & \\
\hline & Mudstone & 3.08 & 0.5 \\
\hline
\end{tabular}


APPENDIX C

GEOCHEMICAL DATA FOR THE

HILLSBORO AIRPORT DRILL HOLE (HBD1) 
HILLSBORO AIRPORT DRILL HOLE (1095 FEET) - IRRADIATION $93 \mathrm{G}$

Samples collected from DOGAMI drill hole (HBDI) at the Hillsboro Airport.

* Concentrations in ppm except $\mathrm{Na}, \mathrm{K}$, and $\mathrm{Fe}$

\begin{tabular}{|c|c|c|c|c|c|c|c|}
\hline $\begin{array}{l}\text { Irrad. } \\
\text { Number }\end{array}$ & $\begin{array}{l}\text { Sample } \\
\text { Number }\end{array}$ & $\mathrm{Na} \%$ & $\mathrm{~K} \%$ & $\mathrm{Rb}$ & Cs & Sr & $\mathrm{Ba}$ \\
\hline GII & $\mathrm{HBD} 1-60.5$ & 1.51 & 1.90 & 59 & 2.49 & 333 & 625 \\
\hline G12 & HBD I - 84 & 1.03 & 1.64 & 51 & 3.06 & & 555 \\
\hline G13 & $\mathrm{HBD} 1-131$ & 0.70 & 1.06 & 42 & 4.00 & 194 & 620 \\
\hline GI4 & HBDI-206. 5 & 1.38 & 2.52 & 101 & 4.84 & 326 & 759 \\
\hline G15 & HBDI - 230 & 1.15 & 1.55 & 83 & 3.31 & 287 & 753 \\
\hline G16 & HBDI - 257 & 1.54 & 1.48 & 69 & 2.95 & 286 & 710 \\
\hline G17 & $\mathrm{HBDI}-303.5$ & 0.92 & 1.46 & 43 & 3.47 & 333 & 589 \\
\hline GI8 & HBDI - 349 & 0.91 & 1.59 & 39 & 4.24 & 439 & 512 \\
\hline G19 & $\mathrm{HBDI}-405.5$ & 2.63 & 2.99 & 51 & 3.88 & 639 & 619 \\
\hline G20 & HBDI - 436.3 & 1.01 & 1.29 & 55 & 3.13 & 388 & 503 \\
\hline G21 & HBDI-492.5 & 0.32 & & 47 & 3.11 & 226 & 485 \\
\hline G22 & $\mathrm{HBD} 1-545.6$ & 0.53 & 1.23 & 57 & 3.79 & 198 & 456 \\
\hline G23 & HBDI - 553 & 0.86 & 1.95 & 61 & 3.86 & 219 & 744 \\
\hline G24 & HBDI -565.7 & 0.68 & 1.23 & 49 & 3.69 & & 547 \\
\hline G25 & $\mathrm{HBDI}-602.3$ & 0.61 & 2.22 & 101 & 6.98 & 343 & 675 \\
\hline G2 6 & HBDI - 659 & 0.30 & & 36 & 4.41 & 403 & 629 \\
\hline G27 & HBDI - 714.8 & 0.52 & 1.06 & 35 & 2.86 & 466 & 537 \\
\hline G28 & HBDI - 755 & 0.54 & 1.49 & 49 & 4.27 & 551 & 727 \\
\hline G29 & $\mathrm{HBDI}-760$ & 1.05 & & & 1.53 & 630 & \\
\hline G30 & HBDI-763.4 & 2.00 & 2.74 & 44 & 2.50 & 200 & 799 \\
\hline G31 & $\mathrm{HBDI}-790.7$ & 0.25 & 1.06 & 45 & 3.56 & 553 & \\
\hline G32 & HBDI-822 & 0.24 & & 40 & 3.60 & 680 & \\
\hline G33 & HBDI-871 & 0.71 & 1.90 & 93 & 5.19 & 489 & 687 \\
\hline G34 & HBDI-920.5 & 0.23 & & 31 & 3.30 & 567 & 568 \\
\hline G35 & $\mathrm{HBDI}-930$ & 0.00 & & & 1.77 & 271 & \\
\hline G36 & $\mathrm{HBDI}-938.5$ & 0.01 & 0.21 & 28 & 2.97 & 208 & 477 \\
\hline
\end{tabular}




$\begin{array}{llrrrrrr}\text { Irrad. } & \text { Sample } & & & & & \\ \text { Number } & \text { Number } & \text { Fe\% } & \text { Sc } & \text { Cr } & \text { Co } & \text { Zr } & \text { Hf } \\ \text { G11 } & \text { HBD1-60.5 } & 3.20 & 11.6 & 64 & 15 & 224 & 9.44 \\ \text { G12 } & \text { HBD1-84 } & 2.84 & 14.9 & 46 & 13 & 332 & 11.09 \\ \text { G13 } & \text { HBD1-131 } & 7.66 & 25.0 & 61 & 26 & 202 & 8.49 \\ \text { G14 } & \text { HBD1-206.5 } & 5.34 & 16.4 & 91 & 19 & 202 & 5.64 \\ \text { G15 } & \text { HBD1-230 } & 7.20 & 17.3 & 165 & 35 & 220 & 6.79 \\ \text { G16 } & \text { HBD1-257 } & 4.33 & 12.9 & 93 & 19 & 228 & 7.50 \\ \text { G17 } & \text { HBD1-303.5 } & 6.67 & 15.0 & 88 & 22 & 163 & 5.34 \\ \text { G18 } & \text { HBD1-349 } & 7.02 & 16.6 & 88 & 19 & 201 & 7.66 \\ \text { G19 } & \text { HBD1-405.5 } & 3.33 & 12.9 & 71 & 14 & 323 & 10.40 \\ \text { G20 } & \text { HBD1-436.3 } & 5.42 & 12.1 & 59 & 17 & 198 & 7.60 \\ \text { G21 } & \text { HBD1-492.5 } & 11.11 & 21.1 & 69 & 15 & 182 & 7.33 \\ \text { G22 } & \text { HBD1-545.6 } & 9.21 & 21.1 & 68 & 14 & 200 & 6.69 \\ \text { G23 } & \text { HBD1-553 } & 6.98 & 19.7 & 74 & 39 & 208 & 6.80 \\ \text { G24 } & \text { HBD1-565.7 } & 10.37 & 24.8 & 51 & 24 & 258 & 6.38 \\ \text { G25 } & \text { HBD1-602.3 } & 7.10 & 17.0 & 81 & 25 & 246 & 6.28 \\ \text { G26 } & \text { HBD1-659 } & 10.90 & 27.3 & 56 & 39 & 371 & 8.25 \\ \text { G27 } & \text { HBD1-714.8 } & 13.14 & 23.6 & 49 & 30 & 203 & 7.37 \\ \text { G28 } & \text { HBD1-755 } & 6.84 & 19.4 & 93 & 16 & 189 & 5.49 \\ \text { G29 } & \text { HBD1-760 } & 7.45 & 7.4 & 8 & 15 & 224 & 9.83 \\ \text { G30 } & \text { HBD1-763.4 } & 4.91 & 7.1 & 4 & 5 & 293 & 9.84 \\ \text { G31 } & \text { HBD1-790.7 } & 10.83 & 27.1 & 61 & 26 & 184 & 9.00 \\ \text { G32 } & \text { HBD1-822 } & 10.44 & 36.0 & 65 & 22 & 373 & 9.52 \\ \text { G33 } & \text { HBD1-871 } & 7.24 & 22.7 & 65 & 51 & 171 & 8.13 \\ \text { G34 } & \text { HBD1-920.5 } & 11.23 & 35.4 & 50 & 60 & 382 & 8.29 \\ \text { G35 } & \text { HBD1-930 } & 21.18 & 32.9 & 90 & 12 & 293 & 13.38 \\ \text { G36 } & \text { HBD1-938.5 } & 13.11 & 45.6 & 61 & 58 & 364 & 12.00\end{array}$


Irrad. Sample

$\begin{array}{llrrrrrr}\text { Number } & \text { Number } & \text { Ta } & \text { Th } & \text { U } & \text { Zn } & \text { As } & \text { Sb } \\ \text { G11 } & \text { HBD1-60.5 } & 0.55 & 10.6 & 3.4 & 59 & & 0.7 \\ \text { G12 } & \text { HBD1-84 } & 0.68 & 10.8 & 2.8 & 63 & 5.0 & \\ \text { G13 } & \text { HBD1-131 } & 1.13 & 9.2 & 2.7 & 114 & 11.2 & 1.7 \\ \text { G14 } & \text { HBD1-206.5 } & 0.91 & 14.8 & 2.3 & 101 & 6.8 & 0.5 \\ \text { G15 } & \text { HBD1-230 } & 3.03 & 9.0 & 4.8 & 108 & 5.2 & \\ \text { G16 } & \text { HBD1-257 } & 2.24 & 8.2 & 2.4 & 84 & 8.4 & 1.0 \\ \text { G17 } & \text { HBD1-303.5 } & 2.52 & 6.3 & 3.5 & 82 & 10.0 & 1.4 \\ \text { G18 } & \text { HBD1-349 } & 2.82 & 7.8 & 2.6 & 82 & 23.1 & 4.8 \\ \text { G19 } & \text { HBD1-405.5 } & 2.29 & 10.4 & 2.3 & 71 & 20.2 & 0.9 \\ \text { G20 } & \text { HBD1-436.3 } & 2.01 & 7.4 & 3.6 & 70 & 13.3 & \\ \text { G21 } & \text { HBD1-492.5 } & 3.29 & 9.8 & 6.7 & 122 & 6.3 & \\ \text { G22 } & \text { HBD1-545.6 } & 3.33 & 10.0 & 3.8 & 99 & 2.1 & \\ \text { G23 } & \text { HBD1-553 } & 3.02 & 8.2 & 3.4 & 109 & 5.0 & 2.8 \\ \text { G24 } & \text { HBD1-565.7 } & 3.67 & 7.6 & 3.1 & 113 & 9.2 & \\ \text { G25 } & \text { HBD1-602.3 } & 2.63 & 12.5 & 3.8 & 98 & 6.8 & 2.5 \\ \text { G26 } & \text { HBD1-659 } & 4.11 & 10.2 & 3.8 & 146 & 6.6 & \\ \text { G27 } & \text { HBD1-714.8 } & 3.42 & 8.1 & 2.6 & 121 & 8.5 & 1.1 \\ \text { G28 } & \text { HBD1-755 } & 2.78 & 7.6 & 3.0 & 103 & 5.8 & 1.5 \\ \text { G29 } & \text { HBD1-760 } & 1.16 & 7.2 & 2.9 & 64 & 8.3 & 1.0 \\ \text { G30 } & \text { HBD1-763.4 } & 1.13 & 7.1 & 3.3 & 55 & 11.4 & \\ \text { G31 } & \text { HBD1-790.7 } & 3.89 & 10.2 & 3.7 & 118 & 9.9 & 10.6 \\ \text { G32 } & \text { HBD1-822 } & 5.03 & 10.6 & 3.8 & 160 & 15.9 & 2.2 \\ \text { G33 } & \text { HBD1-871 } & 3.17 & 11.0 & 3.8 & 122 & 11.2 & 3.4 \\ \text { G34 } & \text { HBD1-920.5 } & 4.69 & 10.0 & 2.9 & 156 & 7.9 & \\ \text { G35 } & \text { HBD1-930 } & 4.23 & 17.8 & 5.5 & 103 & 20.4 & 1.2 \\ \text { G36 } & \text { HBD1-938.5 } & 5.50 & 12.8 & 3.8 & 182 & 3.2 & 8.3\end{array}$




\begin{tabular}{|c|c|c|c|c|c|c|c|}
\hline Irrad. & Sample & & & & & & \\
\hline Number & Number & La & $\mathrm{Ce}$ & $\mathrm{Nd}$ & $\mathrm{Sm}$ & Eu & $\mathrm{Tb}$ \\
\hline GI1 & $\mathrm{HBD} 1-60.5$ & 43.8 & 2.5 & 42 & 7.01 & 1.49 & 0.90 \\
\hline G12 & HBD 1 - 84 & 44.7 & 91.8 & 46 & 8.37 & 1.92 & 1.15 \\
\hline G13 & HBD $1-131$ & 27.3 & 56.7 & 26 & 5.57 & 1.45 & 0.85 \\
\hline G14 & HBD $1-206.5$ & 48.5 & 92.4 & 41 & 7.62 & 1.63 & 1.06 \\
\hline G15 & HBD1 - 230 & 42.8 & 107.8 & 43 & 9.01 & 2.46 & 1.37 \\
\hline G16 & HBD1 - 257 & 32.2 & 63.2 & 30 & 5.95 & 1.53 & 0.87 \\
\hline G17 & $\mathrm{HBD} 1-303.5$ & 24.1 & 45.2 & & 5.21 & 1.40 & 0.79 \\
\hline G18 & $\operatorname{HBD} 1-349$ & 26.4 & 48.3 & 26 & 5.88 & 1.49 & 0.82 \\
\hline G19 & HBD1-405.5 & 38.2 & 91.3 & 41 & 6.52 & 1.76 & 0.96 \\
\hline G2 0 & HBD $1-436.3$ & 28.4 & 49.9 & 26 & 5.92 & 1.35 & 0.70 \\
\hline G2 1 & $\mathrm{HBD} 1-492.5$ & 26.3 & 65.4 & 28 & 6.62 & 1.99 & 1.09 \\
\hline G22 & HBD1 -545.6 & 21.3 & 36.4 & & 3.77 & 1.05 & 0.69 \\
\hline G23 & HBD 1 - 553 & 32.8 & 66.9 & 64 & 6.96 & 1.83 & 0.98 \\
\hline G24 & HBD1-565.7 & 35.5 & 64.8 & 39 & 7.88 & 1.96 & 1.05 \\
\hline G2 5 & HBD $1-602.3$ & 42.2 & 85.5 & 45 & 8.62 & 1.99 & 1.22 \\
\hline G26 & HBD 1 - 659 & 43.2 & 123.0 & 42 & 7.78 & 2.19 & 1.08 \\
\hline G2 7 & HBD $1-714.8$ & 30.8 & 70.8 & 38 & 7.88 & 2.22 & 1.23 \\
\hline G2 8 & HBD1 - 755 & 26.4 & 49.3 & 28 & 5.50 & 1.46 & 0.86 \\
\hline G2 9 & HBD1 - 760 & 25.7 & 49.1 & & 6.79 & 1.18 & 1.01 \\
\hline G30 & HBD $1-763.4$ & 30.6 & 64.3 & 36 & 7.86 & 1.38 & 1.20 \\
\hline G31 & HBD1 -790.7 & 38.4 & 80.1 & 45 & 8.06 & 2.23 & 1.47 \\
\hline G32 & HBD1 - 822 & 63.1 & 118.6 & 64 & 11.96 & 3.17 & 1.76 \\
\hline G33 & HBD1 - 871 & 38.5 & 77.4 & & 8.08 & 2.02 & 1.2 \\
\hline G34 & HBD1 -920.5 & 33.8 & 78.8 & 38 & 8.26 & 2.30 & 1.2 \\
\hline G35 & HBD1 - 930 & 11.2 & 29.2 & 86 & 2.83 & 0.81 & 0.99 \\
\hline G36 & HBD1 -938.5 & 47.8 & 93.6 & & 8.64 & 2.28 & 1.06 \\
\hline
\end{tabular}




$\begin{array}{llrr}\text { Irrad. } & \text { Sample } & \text { Yb } & \text { Lu } \\ \text { Number } & \text { Number } & 2.85 & 0.49 \\ \text { G11 } & \text { HBD1-60.5 } & 2.24 & 0.56 \\ \text { G12 } & \text { HBD1-84 } & 3.24 & 0.53 \\ \text { G13 } & \text { HBD1-131 } & 2.87 & 0.51 \\ \text { G14 } & \text { HBD1-206.5 } & 2.94 & 0.79 \\ \text { G15 } & \text { HBD1-230 } & 4.77 & 0.79 \\ \text { G16 } & \text { HBD1-257 } & 2.66 & 0.42 \\ \text { G17 } & \text { HBD1-303.5 } & 2.52 & 0.44 \\ \text { G18 } & \text { HBD1-349 } & 2.91 & 0.57 \\ \text { G19 } & \text { HBD1-405.5 } & 2.91 & 0.49 \\ \text { G20 } & \text { HBD1-436.3 } & 2.80 & 0.48 \\ \text { G21 } & \text { HBD1-492.5 } & 3.31 & 0.62 \\ \text { G22 } & \text { HBD1-545.6 } & 2.36 & 0.39 \\ \text { G23 } & \text { HBD1-553 } & 2.93 & 0.56 \\ \text { G24 } & \text { HBD1-565.7 } & 3.23 & 0.60 \\ \text { G25 } & \text { HBD1-602.3 } & 3.54 & 0.65 \\ \text { G26 } & \text { HBD1-659 } & 3.15 & 0.64 \\ \text { G27 } & \text { HBD1-714.8 } & 4.18 & 0.78 \\ \text { G28 } & \text { HBD1-755 } & 2.65 & 0.51 \\ \text { G29 } & \text { HBD1-760 } & 3.93 & 0.55 \\ \text { G30 } & \text { HBD1-763.4 } & 4.95 & 0.78 \\ \text { G31 } & \text { HBD1-790.7 } & 4.04 & 0.70 \\ \text { G32 } & \text { HBD1-822 } & 5.22 & 0.84 \\ \text { G33 } & \text { HBD1-871 } & 4.01 & 0.70 \\ \text { G34 } & \text { HBD1-920.5 } & 4.11 & 0.75 \\ \text { G35 } & \text { HBD1-930 } & 1.25 & 1.07 \\ \text { G36 } & \text { HBD1-938.5 } & 2.73 & 0.53\end{array}$


APPENDIX D

GEOCHEMICAL DATA FOR THE PORTLAND INTERNATIONAL AIRPORT DRILL HOLE (MTD1) 
PORTLAND INTERNATIONAL AIRPORT DRILL HOLE (1523 FEET) -IRRADIATION $94 \mathrm{~A}$

Samples collected from DOGAMI drill hole (MTD1) at the Portland International Airport.

* No Potassium concentrations were obtained for these samples.

* Concentrations in ppm except $\mathrm{Na}, \mathrm{K}$, and $\mathrm{Fe}$

$\begin{array}{lllrrrrr}\text { Irrad. } & \text { Sample } & & & & \\ \text { Number } & \text { Number } & \text { Na\% } & \text { Rb } & \text { Cs } & \text { Sr } & \text { Ba } & \text { Fe\% } \\ \text { A1 } & \text { MTD1-30-40 } & 3.15 & 34 & 1.75 & 531 & 400 & 3.75 \\ \text { A2 } & \text { MTD1-50-55 } & 3.44 & 26 & 1.08 & 501 & 344 & 3.26 \\ \text { A3 } & \text { MTD1-105-110 } & 2.64 & 49 & 1.82 & 389 & 597 & 2.90 \\ \text { A4 } & \text { MTD1-155-165 } & 2.64 & 69 & 2.20 & 464 & 662 & 2.69 \\ \text { A5 } & \text { MTD1-225 } & 2.67 & 58 & 1.74 & 412 & 604 & 2.29 \\ \text { A6 } & \text { MTD1-295-300 } & 1.68 & & 2.75 & 334 & 642 & 3.59 \\ \text { A7 } & \text { MTD1-350-358 } & 2.56 & 66 & 2.31 & 376 & 527 & 4.72 \\ \text { A8 } & \text { MTD1-402 } & 0.18 & 48 & 2.33 & 423 & 338 & 8.46 \\ \text { A9 } & \text { MTD1-411.8 } & 0.91 & & 2.60 & & 423 & 7.17 \\ \text { A10 } & \text { MTD1-466-473 } & 1.90 & 53 & 1.69 & 260 & 452 & 3.25 \\ \text { A11 } & \text { MTD1-575 } & 1.17 & 72 & 4.76 & 277 & 605 & 4.76 \\ \text { A12 } & \text { MTD1-692 } & 2.27 & 34 & 0.66 & & 325 & 6.05 \\ \text { A13 } & \text { MTD1-725 } & 1.53 & 26 & 0.84 & 308 & 248 & 7.46 \\ \text { A14 } & \text { MTD1-744 } & 2.46 & 28 & 1.44 & 408 & 337 & 5.50 \\ \text { A15 } & \text { MTD1-782 } & 2.02 & 43 & 1.59 & 331 & 536 & 2.87 \\ \text { A16 } & \text { MTD1-839.5 } & 1.55 & 89 & 4.30 & 224 & 713 & 4.88 \\ \text { A17 } & \text { MTD1-864 } & 2.11 & 54 & 3.37 & 276 & 508 & 5.44 \\ \text { A18 } & \text { MTD1-900 } & 1.22 & 89 & 5.18 & 150 & 643 & 4.15 \\ \text { A19 } & \text { MTD1-958 } & 0.81 & 111 & 6.37 & 155 & 644 & 4.50 \\ \text { A20 } & \text { MTD1-1004 } & 1.69 & 84 & 4.90 & 312 & 720 & 3.18 \\ \text { A21 } & \text { MTD1-1124 } & 0.83 & 108 & 7.29 & 311 & 641 & 4.34 \\ \text { A22 } & \text { MTD1-1241 } & 1.26 & 92 & 5.04 & & 586 & 4.51 \\ \text { A23 } & \text { MTD1-1311 } & 1.00 & 84 & 6.12 & 247 & 616 & 4.53\end{array}$




$\begin{array}{llrrrrrr}\text { Irrad. } & \text { Sample } & & & & \\ \text { Number } & \text { Number } & \text { Sc } & \text { Cr } & \text { Co } & \text { Zr } & \text { Hf } & \text { Ta } \\ \text { A1 } & \text { MTD1-30-40 } & 10.3 & 39 & 16 & 270 & 3.61 & 0.64 \\ \text { A2 } & \text { MTD1-50-55 } & 9.9 & 29 & 14 & 182 & 3.72 & 0.65 \\ \text { A3 } & \text { MTD1-105-110 } & 9.4 & 46 & 12 & 165 & 3.44 & 0.62 \\ \text { A4 } & \text { MTD1-155-165 } & 9.2 & 35 & 11 & & 3.03 & 0.59 \\ \text { A5 } & \text { MTD1-225 } & 8.2 & 32 & 9 & 106 & 2.70 & 0.62 \\ \text { A6 } & \text { MTD1-295-300 } & 11.7 & 51 & 14 & 181 & 3.67 & 0.79 \\ \text { A7 } & \text { MTD1-350-358 } & 15.3 & 45 & 23 & 158 & 5.06 & 0.78 \\ \text { A8 } & \text { MTD1-402 } & 26.3 & 198 & 22 & 280 & 3.42 & 0.56 \\ \text { A9 } & \text { MTD1-411.8 } & 20.0 & 114 & 40 & 203 & 2.30 & 0.35 \\ \text { A10 } & \text { MTD1-466-473 } & 10.7 & 77 & 16 & 165 & 2.29 & 0.49 \\ \text { A11 } & \text { MTD1-575 } & 16.7 & 67 & 17 & 198 & 4.76 & 1.01 \\ \text { A12 } & \text { MTD1-692 } & 21.2 & 127 & 32 & 187 & 2.80 & 0.47 \\ \text { A13 } & \text { MTD1-725 } & 15.4 & 113 & 28 & 239 & 1.72 & 0.29 \\ \text { A14 } & \text { MTD1-744 } & 20.3 & 128 & 23 & 168 & 2.44 & 0.39 \\ \text { A15 } & \text { MTD1-782 } & 9.6 & 83 & 13 & 102 & 2.34 & 0.44 \\ \text { A16 } & \text { MTD1-839.5 } & 12.6 & 69 & 14 & 229 & 5.89 & 1.08 \\ \text { A17 } & \text { MTD1-864 } & 17.4 & 78 & 24 & 181 & 4.49 & 0.74 \\ \text { A18 } & \text { MTD1-900 } & 14.4 & 74 & 18 & 237 & 4.31 & 1.01 \\ \text { A19 } & \text { MTD1-958 } & 15.6 & 77 & 15 & 395 & 4.47 & 1.03 \\ \text { A20 } & \text { MTD1-1004 } & 9.9 & 41 & 9 & 245 & 4.27 & 1.17 \\ \text { A21 } & \text { MTD1-1124 } & 15.4 & 74 & 16 & 217 & 4.21 & 1.04 \\ \text { A22 } & \text { MTD1-1241 } & 15.6 & 63 & 18 & 181 & 4.37 & 1.02 \\ \text { A23 } & \text { MTD1-1311 } & 15.4 & 71 & 17 & 223 & 4.56 & 1.09\end{array}$


Irrad. Sample

$\begin{array}{lcrrrrrr}\text { Number } & \text { Number } & \text { Th } & \text { U } & \text { Zn } & \text { As } & \text { Sb } & \text { La } \\ \text { A1 } & \text { MTD1-30-40 } & 4.1 & 1.7 & 61 & 93.6 & 0.4 & 20.3 \\ \text { A2 } & \text { MTD1-50-55 } & 3.3 & 1.1 & 60 & 9.1 & 20.3 & \\ \text { A3 } & \text { MTD1-105-110 } & 5.3 & 1.4 & 50 & 7.7 & 0.9 & 24.1 \\ \text { A4 } & \text { MTD1-155-165 } & 4.3 & 1.8 & 63 & 5.8 & 0.7 & 17.9 \\ \text { A5 } & \text { MTD1-225 } & 3.6 & 1.8 & 45 & 2.4 & 0.4 & 18.7 \\ \text { A6 } & \text { MTD1-295-300 } & 6.2 & 2.1 & 56 & 4.2 & 1.4 & 25.5 \\ \text { A7 } & \text { MTD1-350-358 } & 7.5 & 2.0 & 93 & 10.9 & 1.9 & 26.0 \\ \text { A8 } & \text { MTD1-402 } & 4.6 & 23.5 & 111 & 12.3 & 13.0 & \\ \text { A9 } & \text { MTD1-411.8 } & 1.8 & 21.6 & 83 & 3.6 & 313.0 & 9.7 \\ \text { A10 } & \text { MTD1-466-473 } & 3.5 & 2.3 & 111 & 1.9 & 4.1 & 13.6 \\ \text { A11 } & \text { MTD1-575 } & 10.1 & 3.9 & 81 & 14.2 & 2.1 & 33.1 \\ \text { A12 } & \text { MTD1-692 } & 2.5 & 2.3 & 98 & 4.5 & 2.3 & 13.1 \\ \text { A13 } & \text { MTD1-725 } & 1.1 & 21.5 & 70 & & & 7.1 \\ \text { A14 } & \text { MTD1-744 } & 1.6 & 13.0 & 92 & 2.8 & 267.1 & 10.6 \\ \text { A15 } & \text { MTD1-782 } & 4.2 & 1.3 & 101 & 3.5 & 0.5 & 15.6 \\ \text { A16 } & \text { MTD1-839.5 } & 10.4 & 3.4 & 78 & & 1.1 & 39.1 \\ \text { A17 } & \text { MTD1-864 } & 6.6 & 2.4 & 98 & 17.3 & 11.9 & 26.1 \\ \text { A18 } & \text { MTD1-900 } & 11.1 & 3.8 & 91 & 6.9 & 2.4 & 37.7 \\ \text { A19 } & \text { MTD1-958 } & 12.7 & 3.9 & 91 & 9.0 & 1.6 & 38.7 \\ \text { A20 } & \text { MTD1-1004 } & 11.4 & 4.3 & 71 & 4.6 & 2.9 & 36.9 \\ \text { A21 } & \text { MTD1-1124 } & 12.9 & 4.7 & 98 & 10.3 & 9.0 & 38.3 \\ \text { A22 } & \text { MTD1-1241 } & 10.5 & 2.9 & 92 & 7.7 & 1.4 & 34.6 \\ \text { A23 } & \text { MTD1-1311 } & 11.8 & 3.3 & 107 & 8.4 & 10.5 & 37.9\end{array}$


Irrad. Sample

$\begin{array}{lccccccc}\text { Number } & \text { Number } & \mathrm{Ce} & \mathrm{Nd} & \mathrm{Sm} & \text { Eu } & \mathrm{Tb} & \text { Yb } \\ \text { A1 } & \text { MTD1-30-40 } & 39.4 & 16 & 3.73 & 1.10 & 0.51 & 1.44 \\ \text { A2 } & \text { MTD1-50-55 } & 35.3 & 19 & 3.77 & 1.05 & 0.48 & 1.42 \\ \text { A3 } & \text { MTD1-105-110 } & 38.2 & & 3.91 & 0.91 & 0.54 & 1.76 \\ \text { A4 } & \text { MTD1-155-165 } & 34.5 & & 3.36 & 0.95 & 0.51 & 1.53 \\ \text { A5 } & \text { MTD1-225 } & 30.8 & 13 & 3.22 & 0.83 & 0.42 & 1.40 \\ \text { A6 } & \text { MTD1-295-300 } & 44.0 & 20 & 4.38 & 1.15 & 0.64 & 1.85 \\ \text { A7 } & \text { MTD1-350-358 } & 49.0 & 23 & 5.04 & 1.22 & 0.79 & 2.59 \\ \text { A8 } & \text { MTD1-402 } & 26.6 & & 3.15 & 1.07 & 0.68 & 2.06 \\ \text { A9 } & \text { MTD1-411.8 } & 23.3 & & 2.89 & 1.13 & 0.58 & 1.96 \\ \text { A10 } & \text { MTD1-466-473 } & 25.5 & 14 & 2.39 & 0.81 & 0.45 & 1.29 \\ \text { A11 } & \text { MTD1-575 } & 62.1 & 25 & 5.72 & 1.33 & 0.86 & 2.46 \\ \text { A12 } & \text { MTD1-692 } & 25.1 & 27 & 3.45 & 1.14 & 0.60 & 1.95 \\ \text { A13 } & \text { MTD1-725 } & 10.9 & & 2.23 & 0.81 & 0.43 & 1.27 \\ \text { A14 } & \text { MTD1-744 } & 20.4 & 28 & 3.27 & 1.16 & 0.58 & 1.82 \\ \text { A15 } & \text { MTD1-782 } & 27.2 & & 3.00 & 0.80 & 0.43 & 1.45 \\ \text { A16 } & \text { MTD1-839.5 } & 71.6 & 30 & 6.55 & 1.45 & 1.01 & 2.98 \\ \text { A17 } & \text { MTD1-864 } & 50.9 & 22 & 5.09 & 1.27 & 0.76 & 2.38 \\ \text { A18 } & \text { MTD1-900 } & 65.7 & 28 & 6.47 & 1.31 & 0.88 & 2.76 \\ \text { A19 } & \text { MTD1-958 } & 76.5 & 34 & 6.70 & 1.37 & 1.05 & 2.91 \\ \text { A20 } & \text { MTD1-1004 } & 74.6 & 29 & 6.35 & 1.26 & 0.95 & 3.06 \\ \text { A21 } & \text { MTD1-1124 } & 76.0 & 35 & 6.74 & 1.47 & 1.03 & 3.01 \\ \text { A22 } & \text { MTD1-1241 } & 63.7 & 27 & 6.15 & 1.33 & 0.90 & 2.78 \\ \text { A23 } & \text { MTD1-1311 } & 74.4 & 33 & 6.43 & 1.43 & 0.98 & 2.74\end{array}$


Irrad. Sample

Number Number Lu

A1

MTD1-30-40 0.21

A2 MTD1-50-55 0.21

A3 MTD1-105-110 0.24

A4 MTD1-155-165 0.23

A5 MTD1-225 0.20

A6 MTD1-295-300 0.27

A7 MTD1-350-358 0.38

A8 MTD1-402 0.31

$\begin{array}{lll}\text { A9 MTD1-411.8 } & 0.26\end{array}$

A10 MTD1-466-473 0.17

A11 MTD1-575 0.35

$\begin{array}{lll}\text { A12 } & \text { MTD1-692 } & 0.31\end{array}$

$\begin{array}{lll}\text { A13 MTD1-725 } & 0.21\end{array}$

A14 MTD1-744 0.25

$\begin{array}{lll}\text { A15 MTD1-782 } & 0.19\end{array}$

A16 MTD1-839.5 0.46

A17 MTD1-864 0.35

A18 MTD1-900 0.40

A19 MTD1-958 0.41

A20 MTD1-1004 0.36

A21 MTD1-1124 0.43

$\begin{array}{lll}\text { A22 } & \text { MTD1-1241 } & 0.41\end{array}$

$\begin{array}{lll}\text { A23 MTD1-1311 } & 0.44\end{array}$ 
APPENDIX E

GEOCHEMICAL DATA FOR STANDARDS

USED IN IRRADIATIONS 93D, 93E, 93G, AND 94A 
STANDARDS USED IN IRRADIATIONS 93D, 93E, 93G, AND 94A

BRC1 - Columbia River basalt (Grande Ronde)

CFA - Coal Fly Ash (1633a)

MAG-1 - - Marine Mud

* Concentrations in ppm except $\mathrm{Na}, \mathrm{K}$, and $\mathrm{Fe}$

Irrad. Sample

Number Number

D38 BCR1

E38 BCR1

BCRI

G3 7

BCR1

A39

CFA (1633a)

$\mathrm{Na} \%$

2.37

$\begin{array}{rr}\mathrm{K} \% & \mathrm{Rb} \\ 1.31 & 44\end{array}$

$\mathrm{Cs}$

Sr

$\mathrm{Ba}$

E39

2.42

1.73

73

1.10

326

625

2.42

45

1.93

387

744

2.98

1.57

59

1.45

543

632

G39

CFA (1633a)

0.17

1.80

0.17

1.88

122

1.83

401

654

A3 8

A13T

CFA (1633a)

0.20

1.88

131

9.91

875

1272

CFA (1633a)

0.20

MAG- 1

2.80

134

10.42

830

1320

D39

MAG - 1

2.84

10.00

933

1333

2.79

3.58

6.49

172

465

2.77

2. 48

128

7.58

511

A3 7

MAG- 1

125

7.46

138

436

Irrad. Sample

Number

Number

D3 8

BCR 1

E38

G3.7

BCR 1

A39

BCR I

E39

G39

BCR 1

Fe\%

$\begin{array}{rr}\text { SC } & \text { Cr } \\ 30.0 & 10 \\ 32.4 & 8 \\ 24.2 & 12 \\ 34.7 & 15 \\ 38.6 & 223 \\ 33.1 & 208 \\ 38.6 & 196 \\ 37.9 & 192 \\ 14.7 & 95 \\ 13.5 & 10 \\ 15.0 & 86\end{array}$

Co

$\mathrm{Zr}$

Hf

9.04

35

168

4.25

9.79

39

236

4.87

9.34

35

123

4.83

10.36

40

5.15

CFA (1633a)

9.84

158

6.88

CFA (1633a)

9.30

45

7.27

A3 8

CFA (1633a)

9.41

43

226

7.29

A13T

CFA (1633a)

9.11

44

240

7.09

D39

MAG - 1

G3 8

MAG - 1

4.41

43

338

3.44

4.59

20

$20 \quad 132$

3. 61

A3 7

MAG- 1

4.26

19193

3. 20

Irrad. Sample

Number Number

D3 8

BCR 1

E38

G37

A39

BCR 1

BCR 1

BCR1

CFA (1633a)

CFA (1633a)

Ta

0.56

Th

U

$\mathrm{Zn}$

As

Sb

2.25

6.4

2.0

3.44

5.8

1. 8

129

2.4

2.0

0.78

6.41 .4

166

2.6

24.210 .6

146

G39

3.46

24.710 .2

211

2.2

A3 8

CFA (1633a)

1.93

$24.7 \quad 10.2$

6.0

CFA (1633a)

1.79

24.49 .9

220145.0

6.8

A13T

MAG - 1

0.95

10.8

221

138.9

6.8

G38

MAG - 1

1.58

11.42 .8

102

13.4

1.1

A3 7

MAG - 1

1.07

$10.4 \quad 1.9$

108

10.6

0.7

1. 3 
Irrad. Sample

Number Number

D38

BCR 1

E38

BCR I

G37

BCR 1

A39

BCR1

E39

CFA (1633a)

La

$\begin{array}{rrrrr}\mathrm{Ce} & \mathrm{Nd} & \mathrm{Sm} & \mathrm{Eu} & \mathrm{Tb} \\ 48.2 & 26 & 5.60 & 1.79 & 0.90 \\ 55.5 & 32 & 6.62 & 2.09 & 1.03 \\ 50.3 & 27 & 6.21 & 1.88 & 0.96 \\ 57.2 & 33 & 6.94 & 2.12 & 1.15\end{array}$

G39

CFA (1633a)

23.4

26.3

24.9

27.0

79.5

16.91

A3 8

CFA (1633a)

79.1

$\begin{array}{lll}166.7 & 71 & 16.83\end{array}$

3.53

2.53

CFA (1633a)

79.1

A13 T

MAG - 1

D39

$M A G-1$
$M A G-1$

G3 8

77.2

$168.3 \quad 76$

16.83

3.58

2.53

40.2

$166.6 \quad 77$

16.51

3.42

2.60

41.0

76.5

32

6.75

1.35

0.87

$\begin{array}{lll}37.0 & 75.4 & 34\end{array}$

7.07

1. 38

0.94

A3 7

1.34

0.93

Irrad. Sample

Number Number

D3 8

BCR1

E38

BCR1

G37

BCR1

A39

BCR 1

E39

G39

CFA (1633a)

Yb

Lu

$2.83 \quad 0.45$

3.180 .56

$2.97 \quad 0.51$

$3.68 \quad 0.53$

A3 8

A13T

CFA (1633a)

7.92

0.92

CFA (1633a)

7.13

1.13

CFA (1633a)

7.50

1.08

D39

MAG - 1

G38

MAG- 1

7.24

1.05

2.40

0.35

A3 7

MAG-1

2. 53

0.41

2.45

0.34 
APPENDIX F

STATISTICAL DATA FOR GEOCHEMICAL GROUPS 
Comparison of Boring Lava Flows

on the West Side of the Tualatin Mountains

Barnes Road (BR) vs. Sylvan Hill (SH)

** F TESTS

$\mathrm{Ho}: \mathrm{V} 1=\mathrm{V} 2$

C- $\mathrm{H} 1: \mathrm{V} 1<>\mathrm{V} 2$

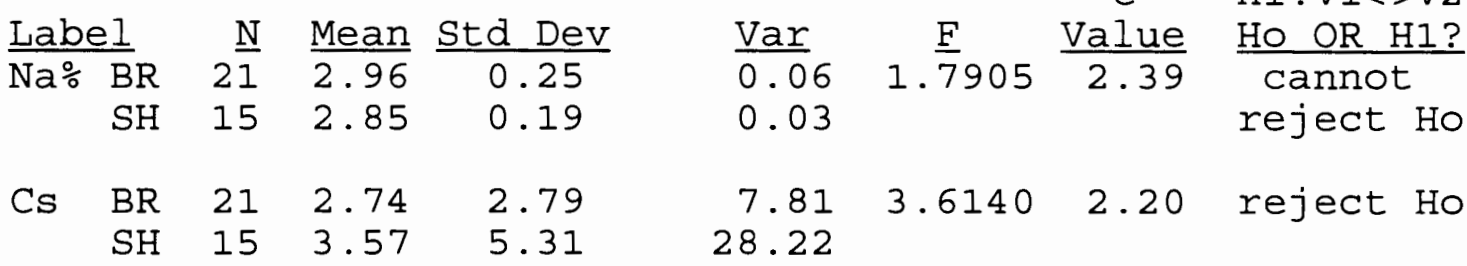

$\begin{array}{lllllllll}\text { Ba } & \text { BR } & 21 & 446 & 120.01 & 14403.10 & 1.2084 & 2.20 & \text { cannot }\end{array}$ SH $15 \quad 493 \quad 131.93 \quad 17404.41 \quad$ reject Ho

$\mathrm{Fe} \% \mathrm{BR} \quad 21 \quad 6.18 \quad 0.40$

$\begin{array}{llll}\mathrm{SH} & 15 & 6.51 & 0.29\end{array}$

$0.16 \quad 1.9036 \quad 2.39 \quad$ cannot

0.08 reject Ho

$\begin{array}{lllll}\text { SC } & \text { BR } & 21 & 17.9 & 1.46\end{array}$

SH $\quad 15 \quad 18.1 \quad 1.00$

$2.14 \quad 2.1478 \quad 2.39 \quad$ cannot

1.00

reject Ho

$\begin{array}{llllll}\text { Cr } & \text { BR } & 21 & 190 & 28.74\end{array}$

SH $15 \quad 276 \quad 56.83$

$825.93 \quad 3.9102 \quad 2.20$ reject Ho

$\begin{array}{lllll}\text { CO } & \text { BR } & 21 & 30 & 2.47\end{array}$

$\begin{array}{llll}\text { SH } & 15 & 37 & 3.11\end{array}$

3229.52

$\begin{array}{lllll}\text { Hf } & \text { BR } & 21 & 3.73 & 0.33\end{array}$

$\begin{array}{llll}\text { SH } & 15 & 3.89 & 0.35\end{array}$

6.12

1.5835

2.20

cannot

9.69

reject Ho

$\begin{array}{llll}\text { SH } & 15 & 3.89 & 0.35\end{array}$

$\begin{array}{lllll}\text { Th } & \text { BR } & 21 & 1.8 & 0.42\end{array}$

$\begin{array}{llll}\mathrm{SH} & 15 & 3.4 & 0.67\end{array}$

0.11

0.12

$1.1203 \quad 2.20$

cannot

reject Ho

$\begin{array}{lllll}\text { La } & \text { BR } & 21 & 19.3 & 1.51\end{array}$

SH $\quad \begin{array}{lll}15 & 26.6 & 7.00\end{array}$

$0.18 \quad 2.5834 \quad 2.20$ reject Ho 0.46

$2.2921 .430 \quad 2.20$ reject Ho 49.00

$\begin{array}{lllll}\mathrm{Ce} & \mathrm{BR} & 21 & 41.5 & 3.28\end{array}$

10.76

15.65

1.4550

2.20

cannot

$\begin{array}{llll}\mathrm{SH} & 15 & 60.5 & 3.96\end{array}$

0.14

$2.1945 \quad 2.20$

reject Ho

$\begin{array}{lllll}\text { Sm } & \text { BR } & 21 & 5.09 & 0.37\end{array}$

SH $\quad 15$

6.07

0.55

0.30

cannot

reject Ho

$\begin{array}{lllll}\text { Eu } & \text { BR } & 21 & 1.71 & 0.15\end{array}$

0.023

1.1624

0.019

2.39

cannot

reject Ho

$\begin{array}{lllll}\mathrm{Tb} & \mathrm{BR} & 21 & 0.64 & 0.07\end{array}$

SH 15

0.72

0.13

0.01

3.2874

2.20

reject Ho

0.02 
Comparison of Boring Lava Flows

on the west Side of the Tualatin Mountains

Barnes Road (BR) vs. Cornell Mountain (CM)

$\mathrm{HO}: \mathrm{V} 1=\mathrm{V} 2$

$\mathrm{C}-\mathrm{H} 1: \mathrm{V} 1<>\mathrm{V} 2$

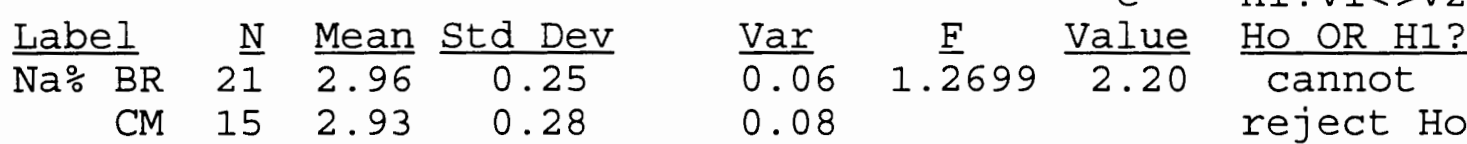

$\begin{array}{llllll}\text { CS } & \text { BR } & 21 & 2.74 & 2.79 & 7.81\end{array}$

10.24

$1.3117 \quad 2.20$ cannot

reject Ho

$\begin{array}{llllll}\text { Ba } & \text { BR } & 21 & 446 & 120.01 & 14403.10\end{array}$

CM $\quad 15 \quad 413 \quad 91.04$

8287.86

$1.7379 \quad 2.39$

cannot reject Ho

$\begin{array}{lllll}\mathrm{Fe} \% & \mathrm{BR} & 21 & 6.18 & 0.40\end{array}$

0.156

1.0232

2.20

cannot

$\begin{array}{llll}C M & 15 & 6.43 & 0.40\end{array}$

0.160

reject Ho

$\begin{array}{lllll}\text { SC } & \text { BR } & 21 & 17.9 & 1.46\end{array}$

2.14

1.6612

2.20

cannot

CM $\quad 15 \quad 21.9$

1.89

3.56

reject Ho

$\begin{array}{lllll}\text { Cr } & \text { BR } & 21 & 190 & 28.74\end{array}$

825.93

1.5533

2.39

cannot

reject Ho

$\begin{array}{lllll}\text { Co } & \text { BR } & 21 & 30 & 2.47\end{array}$

$\begin{array}{llll}\text { CM } & 15 & 35 & 1.87\end{array}$

6.12

1.7498

2.39

cannot

3.50

reject Ho

$\begin{array}{lllll}\text { Hf } & \text { BR } & 21 & 3.73 & 0.33\end{array}$

0.11

1.1240

2.39

cannot

$\begin{array}{lll}C M & 15 & 3.47\end{array}$

0.31

0.10

reject Ho

$\begin{array}{lllll}\text { Th } & \text { BR } & 21 & 1.8 & 0.42\end{array}$

$0.18 \quad 1.3185$

2.20

cannot

CM 15

1.7

0.48

0.23

reject Ho

$\begin{array}{lllll}\text { La } & \text { BR } & 21 & 19.3 & 1.51\end{array}$

2.29

4.092

2.20

reject Ho

$\begin{array}{llll}\text { CM } & 15 & 17.8 & 3.06\end{array}$

9.36

$\begin{array}{lllll}\text { Ce } & \text { BR } & 21 & 41.5 & 3.28\end{array}$

10.76

1.6467

2.39

cannot

6.53

reject Ho

$\begin{array}{lllll}\text { Sm } & \text { BR } & 21 & 5.09 & 0.37\end{array}$

CM $15 \quad 4.65$

0.68

0.14

0.46

3.3904

2.20

reject Ho

$\begin{array}{lllll}\text { Eu } & \text { BR } & 21 & 1.71 & 0.15\end{array}$

CM $\quad 15 \quad 1.59$

0.17

0.02

1.2554

2.20

cannot

0.03

reject $\mathrm{Ho}$

$\begin{array}{lllll}\text { Tb BR } 21 & 0.64 & 0.07\end{array}$

0.005

1.6610

2.20

cannot $\begin{array}{lll}\text { CM } & 15 & 0.67\end{array}$

0.09

0.009 reject Ho 


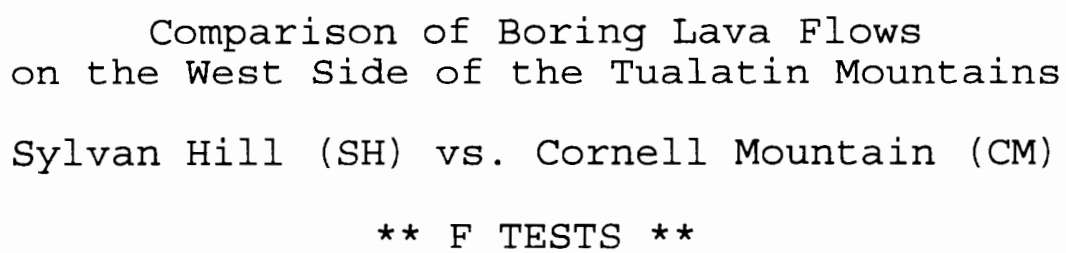

C- $\mathrm{H} 1: \mathrm{V} 1<>\mathrm{V} 2$

\begin{tabular}{|c|c|c|c|c|c|c|c|c|}
\hline \multicolumn{2}{|c|}{ Iabe 1} & $\underline{N}$ & Mean & std Dev & $\underline{\operatorname{Var}}$ & $\underline{F}$ & Value & Ho OR HI? \\
\hline $\mathrm{Na} \%$ & $\overline{\mathrm{SH}}$ & $1 \overline{5}$ & 2.85 & 0.19 & $\overline{0.03}$ & $2 . \overline{2} 738$ & 2.46 & cannot \\
\hline & $\mathrm{CM}$ & 15 & 2.93 & 0.28 & 0.08 & & & reject Ho \\
\hline $\mathrm{Cs}$ & $\mathrm{SH}$ & 15 & 3.57 & 5.31 & 28.22 & 2.7553 & 2.46 & reject Ho \\
\hline & $C M$ & 15 & 3.39 & 3.20 & 10.24 & & & \\
\hline
\end{tabular}

$\begin{array}{lllllllll}\mathrm{Ba} & \mathrm{SH} & 15 & 493 & 131.93 & 17404.41 & 2.1000 & 2.46 & \text { cannot }\end{array}$ CM $15 \quad 413 \quad 91.04 \quad 8287.86 \quad$ reject Ho

Fe\% SH $\quad 15 \quad 6.51 \quad 0.29$

0.082

1.9478

2.46

cannot

0.160

reject Ho

$\begin{array}{lllll}\mathrm{SC} & \mathrm{SH} & 15 & 18.1 & 1.00\end{array}$

CM $15 \quad 21.9 \quad 1.89$

1.00

3.56

3.56792 .46 reject Ho

$\begin{array}{lllll}\mathrm{Cr} & \mathrm{SH} & 15 & 276 & 56.83\end{array}$

CM $15 \quad 200 \quad 23.06$

3229.52

6.0738

2.46

reject Ho 531.71

$\begin{array}{lllll}\text { Co } & \text { SH } & 15 & 37 & 3.11\end{array}$

$\begin{array}{llll}\mathrm{CM} & 15 & 35 & 1.87\end{array}$

9.69

2.7707

2.46

reject $\mathrm{Ho}$ 3.50

$\begin{array}{lllll}H f & \text { SH } & 15 & 3.89 & 0.35\end{array}$

$\begin{array}{llll}\text { CM } & 15 & 3.47 & 0.31\end{array}$

0.12

1.2592

2.46

cannot

0.10

reject Ho

$\begin{array}{lllll}\text { Th } & \text { SH } & 15 & 3.4 & 0.67\end{array}$

0.46

1.9593

2.46

cannot

0.23

reject Ho

La $\quad \mathrm{SH} \quad 15 \quad 26.6 \quad 7.00$

CM $\quad \begin{array}{lll}15 & 17.8 & 3.06\end{array}$

49.00

5.2370

2. 46

reject $\mathrm{Ho}$

9.36

$\begin{array}{lllll}\mathrm{Ce} & \mathrm{SH} & 15 & 60.5 & 3.96\end{array}$

CM $15 \quad 35.3 \quad 2.56$

15.65

6.53

2.3959

2.46

cannot

reject Ho

$\begin{array}{lllll}\text { Sm } & \text { SH } & 15 & 6.07 & 0.55\end{array}$

0.30

1.5449

2.46

cannot

reject Ho

$\begin{array}{lllll}E u & S H & 15 & 1.91 & 0.14\end{array}$

$\begin{array}{llll}\text { CM } & 15 & 1.59 & 0.17\end{array}$

0.02

1.4593

2.46

cannot reject Ho

$\begin{array}{lllll}\text { Tb } & \text { SH } & 15 & 0.72 & 0.13\end{array}$

$\begin{array}{llll}\text { CM } & 15 & 0.67 & 0.09\end{array}$

0.018

1.9792

2.46

cannot reject Ho 
Comparison of Columbia River Source sediments (CRSS) and

Lower Troutdale Formation (LTFM)

* F TESTS * *

$\mathrm{Ho}: \mathrm{V} 1=\mathrm{V} 2$

$\mathrm{C}-\mathrm{H} 1: \mathrm{V} 1<>\mathrm{V} 2$

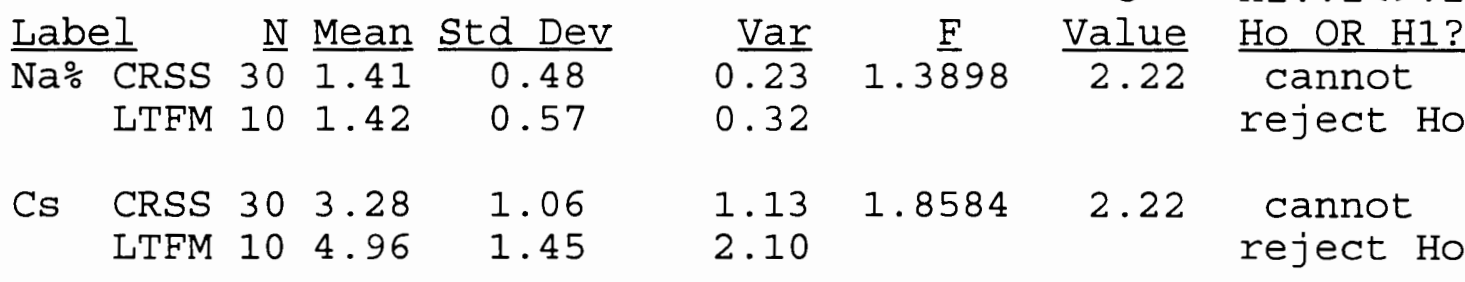

Ba CRSS $30 \quad 594 \quad 103.13 \quad 10636.03 \quad 2.2359 \quad 2.90$ cannot LTFM $10 \quad 620 \quad 68.97 \quad 4756.96$ reject Ho LTFM $10 \quad 4.50 \quad 0.58$

0.34

SC CRSS $30 \quad 14.5 \quad 3.07$

LTFM $10 \quad 14.8 \quad 2.14$

$9.412 .0507 \quad 2.90 \quad$ cannot

4.59 reject Ho

Cr CRSS $30 \quad 82 \quad 29.59$

875.77

5.2325

2.90

reject Ho

LTFM $10 \quad 66 \quad 12.94$

167.37

$\begin{array}{lllll}\text { Co CRSS } 30 & 16 & 5.55 & 30.76\end{array}$

$\begin{array}{lllll}\text { LTFM } & 10 & 17 & 4.27 & 18.24\end{array}$

$1.6862 \quad 2.90$

cannot reject Ho

Hf CRSS $30 \quad 7.04 \quad 1.48$ LTFM $10 \quad 4.64 \quad 0.51$

2.18

8.4768

2.90

reject $\mathrm{Ho}$

Th CRSS $30 \quad 9.2 \quad 1.90$

LTFM $10 \quad 10.5 \quad 2.03$

3.59

1.1512

2.22

cannot reject Ho

La CRSS $30 \quad 35.2 \quad 8.18$

66.85

2.6822

2.90

cannot LTFM $10 \quad 34.8$

4.99

24.92 reject Ho

Ce CRSS $30 \quad 67.0 \quad 14.43$

208.23

2.0331

2.90

cannot LTFM $10 \quad 66.5 \quad 10.12$

102.42 reject Ho

Sm CRSS $30 \quad 5.88 \quad 1.22$

1. 49

3.7506

2.90

reject Ho LTFM $10 \quad 6.12$

0.63

0.40

Eu CRSS $30 \quad 1.37 \quad 0.25$

0.060 LTFM $10 \quad 1.35$

0.08

0.007

8.3745

2.90

reject $\mathrm{Ho}$

$\begin{array}{lllll}\text { Tb CRSS } & 30 & 0.84 & 0.13\end{array}$

$$
0.02
$$

1.6659

2.90

cannot reject Ho 
Comparison of Columbia River Source Sediments (CRSS) and Portland Hills silt (PHS)

$\mathrm{Ho}: \mathrm{V} 1=\mathrm{V} 2$

$\mathrm{C}-\mathrm{H} 1: \mathrm{V} 1<>\mathrm{V} 2$ $\frac{\text { Label }}{\text { Na\% CRSS }} 3 \frac{\mathrm{N}}{30} \frac{\text { Mean }}{1.41} \frac{\text { Std Dev }}{0.48}$ PHS $41.39 \quad 0.31$

Cs CRSS $30 \quad 3.28$ PHS 43.25
1.06

0.37 $\underline{\text { Var }}$ 0.23 0.10

1.13

0.14
$2.3 \frac{F}{784}$ Value 8.64

8.3052

.

4.0175

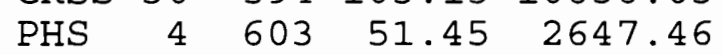

Fe\% CRSS 306.21 PHS $4 \quad 4.26$

1.09

0.46

1.18

0.21

SC CRSS $30 \quad 14.5$ PHS $4 \quad 15.2$

3.07

1.63

9.41

2.66

$\begin{array}{lllll}\text { Cr CRSS } & 30 & 82 & 29.59 & 875.77\end{array}$ $\begin{array}{lllll}\text { PHS } & 4 & 75 & 12.12 & 146.96\end{array}$

Co CRSS $30 \quad 16 \quad 5.55$ $\begin{array}{llll}\text { PHS } & 4 & 13 & 2.61\end{array}$

Hf CRSS $307.04 \quad 1.48$ PHS $4 \quad 8.43$

1.33

1. 76

Th

CRSS $30 \quad 9.2 \quad 1.90$

PHS 411.5

1.11

3.59

1.23

La CRSS $30 \quad 35.2$

PHS $4 \quad 39.9$

8.18

5.96

66.85

35.49

Ce CRSS $30 \quad 67.0$ PHS 479.3

14.43

7.52

208.23

56.59

Sm CRSS $30 \quad 5.88$ PHS 46.65

$$
\text { 1. } 22
$$

0.88

1.49

0.77

2.9120

5.4912

3.5435

5.9593

5.9593

4. 5294

1.2411

1.2411

8.64

8.64

8.64

8.64

8.64

8.64

8.64

8.64

8.64

1.8834

8.64

3.6796

.6796

8.64

I. 9407

1.9407

0.060

0.25

0.18

0.032

1. 8565

PHS 41.49

0.13

0.15

0.017

0.022

cannot? reject Ho

cannot reject $\mathrm{Ho}$

cannot reject $\mathrm{Ho}$

cannot reject Ho

cannot reject $\mathrm{Ho}$

cannot reject $\mathrm{Ho}$

cannot reject Ho

cannot reject $\mathrm{Ho}$

cannot reject $\mathrm{Ho}$

cannot reject Ho

cannot reject Ho

Tb CRSS $30 \quad 0.84$ PHS $4 \quad 0.94$

$1.3500 \quad 2.92$
8.64

8.64 cannot reject $\mathrm{HO}$

cannot reject Ho cannot reject Ho 
Comparison of Columbia River source Sediments (CRSS) and

Portland Hills silt (PHS)

* * T TESTS * *

$\mathrm{HO}: \mathrm{X} 1=\mathrm{X} 2$

$\mathrm{C}-\mathrm{HI}: \mathrm{X} 1<>\mathrm{X} 2$

$\frac{\text { Label }}{\mathrm{Na} \% \text { CRSS }} 3 \frac{\mathrm{N}}{10} \frac{\text { Mean }}{1.41} \frac{\text { Std Dev }}{0.48}$ Sp $\underline{\mathrm{T}} \quad \frac{\text { Value }}{+/-} \frac{\text { Ho OR HI? }}{\text { cannot }}$

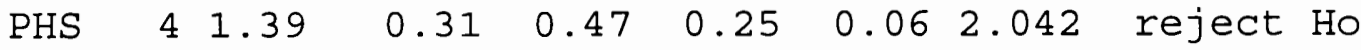

Cs CRSS $303.28 \quad 1.06 \quad+/-$ cannot $\begin{array}{llllllll}\text { PHS } & 4 & 3.25 & 0.37 & 1.02 & 0.54 & 0.06 & 2.042 \\ \text { reject Ho }\end{array}$

Ba CRSS $30 \quad 594103.13 \quad+/-$ cannot PHS $4603 \quad 51.4599 .4352 .93-0.162 .042$ reject Ho

Fe\% CRSS $30 \quad 4.23 \quad 1.09$

$+1-\quad$ cannot

PHS $44.26 \quad 0.46 \quad 1.04 \quad 0.56-0.052 .042$ reject Ho

SC CRSS $30 \quad 14.5 \quad 3.07$

PHS $4 \quad 15.2 \quad 1.63$

$+1-\quad$ cannot

$2.961 .58-0.422 .042$ reject $\mathrm{Ho}$

Cr CRSS $30 \quad 82 \quad 29.59$

$+/-\quad$ cannot

$\begin{array}{llllllll}\text { PHS } & 4 & 75 & 12.12 & 28.42 & 15.13 & 0.42 & 2.042 \\ \text { reject Ho }\end{array}$

CO CRSS $30 \quad 16 \quad 5.55$

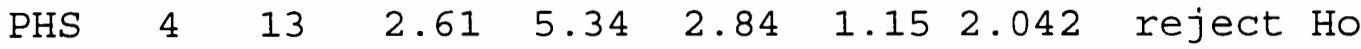

Hf CRSS $30 \quad 7.04 \quad 1.48$

PHS $4 \quad 8.43 \quad 1.33$

$+1-\quad$ cannot

Th CRSS $\begin{array}{llll}30 & 9.2 & 1.90\end{array}$

PHS 4 11.5 1.11

$\begin{array}{lllll}1.46 & 0.78 & -1.79 & 2.042 & \text { reject Ho }\end{array}$

$1.840 .98-2.262 .042$ reject Ho

La CRSS $30 \quad 35.2 \quad 8.18$

PHS $439.9 \quad 5.96$

$7.994 .26-1.122 .042$ reject Ho

Ce CRSS $30 \quad 67.0 \quad 14.43$

PHS 479.3

7.52

$+/$ cannot

2.042 reject $\mathrm{Ho}$

Sm CRSS $30 \quad 5.88 \quad 1.22$

$+1-\quad$ cannot

PHS $\quad 4 \quad 6.65 \quad 0.88$

$1.190 .64-1.202 .042$ reject Ho

$\begin{array}{lllll}\mathrm{Eu} & \text { CRSS } & 30 & 1.37 & 0.25\end{array}$

PHS $41.49 \quad 0.18$

$+/$ cannot

Tb CRSS $30 \quad 0.84 \quad 0.13$

$0.240 .13-0.962 .042$ reject Ho

PHS 40.94

0.15

0.13

+ cannot

2.042 reject Ho 
Comparison of Columbia River source Sediments (CRSS) and

Columbia River Basalt Group Sediments (CRBS)

\section{** F TESTS * *}

$\mathrm{Ho}: \mathrm{V} 1=\mathrm{V} 2$

C- $\quad \mathrm{H} 1: \mathrm{V} 1<>\mathrm{V} 2$

\begin{tabular}{|c|c|c|c|c|c|c|c|c|}
\hline Lab & & $\mathrm{N}$ & Mean & Std Dev & Var & $\underline{F}$ & Value & Ho OR H1? \\
\hline $\mathrm{Na} \%$ & CRSS & 30 & 1.41 & 0.48 & $0 . \overline{23}$ & $18 . \overline{0} 11$ & 3.32 & reject Ho \\
\hline & CRBS & 3 & 1.50 & 2.04 & 4.16 & & & \\
\hline $\mathrm{Cs}$ & CRSS & 30 & 3.28 & 1.06 & 1.13 & 2.1372 & 3.32 & cannot \\
\hline & CRBS & 3 & 2.09 & 1.55 & 2.41 & & & reject Ho \\
\hline Ba & CRSS & 30 & 594 & 103.13 & 10636.03 & 6.1419 & 19.45 & cannot \\
\hline & CRBS & 3 & 574 & 41.61 & 1731.72 & & & reject Ho \\
\hline $\mathrm{Fe} \%$ & CRSS & 30 & 6.21 & 1.09 & 1.18 & 1.1253 & 19.45 & cannot \\
\hline & CRBS & 3 & 11.0 & 1.02 & 1.05 & & & reject $\mathrm{Ho}$ \\
\hline SC & CRSS & 30 & 14.5 & 3.07 & 9.41 & 8.7987 & 3.32 & reject Ho \\
\hline & CRBS & 3 & 46.0 & 9.10 & 82.83 & & & \\
\hline $\mathrm{Er}$ & CRSS & 30 & 82 & 29.59 & 875.77 & 1.7515 & 19.45 & cannot \\
\hline & CRBS & 3 & 50 & 22.36 & 500.00 & & & reject Ho \\
\hline Co & CRSS & 30 & 16 & 5.55 & 30.76 & 4.8739 & 19.45 & cannot \\
\hline & CRBS & 3 & 32 & 2.51 & 6.31 & & & reject Ho \\
\hline $\mathrm{HE}$ & CRSS & 30 & 7.04 & 1.48 & 2.18 & 1.5027 & 3.32 & cannot \\
\hline & CRBS & 3 & 7.61 & 1.81 & 3.27 & & & reject Ho \\
\hline Th & CRSS & 30 & 9.2 & 1.90 & 3.59 & 3.7976 & 3.32 & reject Ho \\
\hline & CRBS & 3 & 8.0 & 3.69 & 13.64 & & & \\
\hline La & CRSS & 30 & 35.2 & 8.18 & 66.85 & 1.3103 & 19.45 & cannot \\
\hline & CRBS & 3 & 43.4 & 7.14 & 51.02 & & & reject Ho \\
\hline $\mathrm{Ce}$ & CRSS & 30 & 67.0 & 14.43 & 208.23 & 20.038 & 3.32 & reject Ho \\
\hline & CRBS & 3 & 90.9 & 64.60 & 4172.58 & & & \\
\hline $\mathrm{Sm}$ & CRSS & 30 & 5.88 & 1.22 & 1.49 & 4.4815 & 3.32 & reject Ho \\
\hline & CRBS & 3 & 10.7 & 2.59 & 6.68 & & & \\
\hline Eu & CRSS & 30 & 1.37 & 0.25 & 0.060 & 8.6465 & 3.32 & reject Ho \\
\hline & CRBS & 3 & 3.05 & 0.72 & 0.522 & & & \\
\hline $\mathrm{Tb}$ & CRSS & 30 & 0.84 & 0.13 & 0.02 & 2.2791 & 3.32 & cannot \\
\hline & CRBS & 3 & 1.62 & 0.19 & 0.04 & & & reject $\mathrm{H}$ \\
\hline
\end{tabular}


Comparison of Columbia River Source Sediments (CRSS) and

Reed Island Ashes (RIA)

* F TESTS * *

$\mathrm{Ho}: \mathrm{V} 1=\mathrm{V} 2$

$\mathrm{C}-\mathrm{H} 1: \mathrm{V} 1<>\mathrm{V} 2$

$\frac{\text { Label }}{\text { Na\% CRSS }} 3_{0}^{\frac{N}{0}} \frac{\text { Mean }}{1.41} \frac{\text { Std Dev }}{0.48} \quad \frac{\text { Var }}{0.23} \quad 1.2700 \frac{\text { F }}{249.05} \frac{\text { Value }}{\text { Cannot }}$

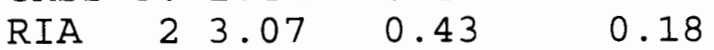

reject Ho

CS CRSS $30 \quad 3.28 \quad 1.06$

1.13

$\begin{array}{llll}\text { RIA } & 2 & 1.59 & 0.80\end{array}$

0.65

$1.7440 \quad 249.05$

cannot

reject Ho

Ba CRSS $30 \quad 594 \quad 103.13 \quad 10636.03 \quad 2.6976 \quad 249.05$

cannot

$\begin{array}{lllll}\text { RIA } & 2 & 489 & 62.79 & 3942.72\end{array}$

reject Ho

Fe\% CRSS $30 \quad 6.21 \quad 1.09$

$\begin{array}{llll}\text { RIA } & 2 & 2.41 & 0.22\end{array}$

1.18

0.05

9.41

SC CRSS $30 \quad 14.5$

$\begin{array}{lll}\text { RIA } 2 & 2.5\end{array}$

3.07

0.76

0.58

$\begin{array}{llll}\text { Cr CRSS } & 30 & 82 & 29.59\end{array}$

$\begin{array}{lll}\text { RIA } 2 & 23 & 1.19\end{array}$

875.77

1.42

Co CRSS $30 \quad 16 \quad 5.55$

$\begin{array}{llll}\text { RIA } 2 & 10 & 0.71\end{array}$

30.76
0.51

2.18

0.11

RIA 24.13

1. 48

0.33

3.59

0.51

1.90

RIA 24.3

La CRSS $30 \quad 35.2$

$\begin{array}{lll}\text { RIA } & 2 & 22.3\end{array}$

8.18

1.29

66.85

1.66

Ce CRSS $30 \quad 67.0$ RIA 240.2

14.43

6.78

208.23

45.93

Sm CRSS $30 \quad 5.88$

RIA 23.96

1. 22

0.47

1.49

0.22

Eu CRSS $30 \quad 1.37$

RIA 21.05

0.25

0.02

0.0603

0.0005

Tb CRSS $30 \quad 0.84$

$\begin{array}{lll}\text { RIA } 2 & 0.52\end{array}$

0.13

0.08

0.02

0.01

$2.6203 \quad 249.05$
$23.633 \quad 249.05$

$60.193 \quad 249.05$

cannot reject Ho

$16.250 \quad 249.05$

cannot reject Ho

$616.18 \quad 249.05$ reject $\mathrm{Ho}$

cannot reject $\mathrm{Ho}$

cannot reject $\mathrm{Ho}$

7.1099249 .05

cannot reject Ho

$40.275 \quad 249.05$

cannot

reject $\mathrm{Ho}$

$4.5340 \quad 249.05$

cannot reject Ho

$6.8156 \quad 249.05$

cannot reject Ho

cannot reject $\mathrm{Ho}$

cannot reject Ho 
Comparison of Columbia River source sediments (CRSS) and

Reed Island Ashes (RIA)

** T TESTS **

$\mathrm{Ho}: \mathrm{X} 1=\mathrm{X} 2$

C- $\mathrm{H} 1: \mathrm{X} 1<>\mathrm{X} 2$

$\frac{\text { Label }}{\text { Na\% CRSS }} 3^{\frac{N}{0}} \frac{\text { Mean }}{1.41} \frac{\text { Std Dev }}{0.48} \quad \underline{\text { Sp }}$ Se $\underline{\text { Value Ho OR H1? }}$ $\begin{array}{llllllll}R I A & 2 & 3.07 & 0.43 & 0.48 & 0.35 & -4.77 & 2.042 \\ \end{array}$

Cs CRSS $30 \quad 3.28 \quad 1.06$

$\begin{array}{llllllll}\text { RIA } & 2 & 1.59 & 0.80 & 1.05 & 0.77 & 2.19 & 2.042 \\ \text { reject Ho }\end{array}$

$\mathrm{Ba}$ CRSS $30 \quad 594 \quad 103.13$

+ - cannot

$\begin{array}{llllllll}\text { RIA } & 2 & 489 & 62.79 & 102.04 & 74.52 & 1.42 & 2.042 \\ \text { reject Ho }\end{array}$

Fe\% CRSS $30 \quad 6.21 \quad 1.09$

$+1-$

$\begin{array}{llll}\text { RIA } \quad 2 & 2.41 & 0.22\end{array}$

$\begin{array}{lllll}1.07 & 0.78 & 4.86 & 2.042 & \text { reject Ho }\end{array}$

SC CRSS $30 \quad 14.5 \quad 3.07$

$\begin{array}{llll}\text { RIA } & 2 & 8.5 & 0.76\end{array}$

$+1-$

$\begin{array}{lllll}3.02 & 2.21 & 2.72 & 2.042 & \text { reject Ho }\end{array}$

Cr CRSS $30 \quad 82 \quad 29.59$

$\begin{array}{llllllll}\text { RIA } & 2 & 23 & 1.19 & 29.10 & 21.25 & 2.78 & 2.042 \text { reject Ho }\end{array}$

CO CRSS $30 \quad 16 \quad 5.55$

$+/-$ cannot

$\begin{array}{llllllll}\text { RIA } & 2 & 10 & 0.71 & 5.45 & 3.98 & 1.67 & 2.042 \\ \text { reject Ho }\end{array}$

HE CRSS $30 \quad 7.04 \quad 1.48$

$\begin{array}{llll}\text { RIA } \quad 2 \quad 4.13 & 0.33\end{array}$

$1.45 \quad 1.06 \quad 2.74 \quad 2.042$ reject Ho

Th CRSS $30 \quad 9.2 \quad 1.90$

$\begin{array}{llll}\text { RIA } & 2 & 4.3 & 0.71\end{array}$

$\begin{array}{llll}1.87 & 1.36 & 3.59 & 2.042 \\ \text { reject HO }\end{array}$

La CRSS $30 \quad 35.2 \quad 8.18$

$\begin{array}{llll}\text { RIA } \quad 2 & 22.3 & 1.29\end{array}$

8.045 .872 .202 .042 reject Ho

Ce CRSS $30 \quad 67.0 \quad 14.43$

$\begin{array}{llllllll}\text { RIA } & 2 & 40.2 & 6.78 & 14.24 & 10.40 & 2.58 & 2.042 \\ \text { reject Ho }\end{array}$

Sm CRSS $30 \quad 5.88 \quad 1.22$

$\begin{array}{llll}\text { RIA } & 2 & 3.96 & 0.47\end{array}$

$1.20 \quad 0.88+1-$

$1.20 \quad 0.88 \quad 2.192 .042$ reject Ho

Eu CRSS $30 \quad 1.37 \quad 0.25$

$+1-\quad$ cannot

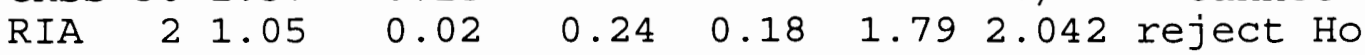

Tb CRSS $30 \quad 0.84 \quad 0.13$

$\begin{array}{llll}\text { RIA } \quad 2 & 0.52 & 0.08\end{array}$

$+1-$

$\begin{array}{llll}0.13 & 0.09 & 3.41 & 2.042 \\ \text { reject } \mathrm{Ho}\end{array}$ 
Comparison of Columbia River source Sediments (CRSS) and

Young Columbia River Sediments (YCRS)

** F TESTS

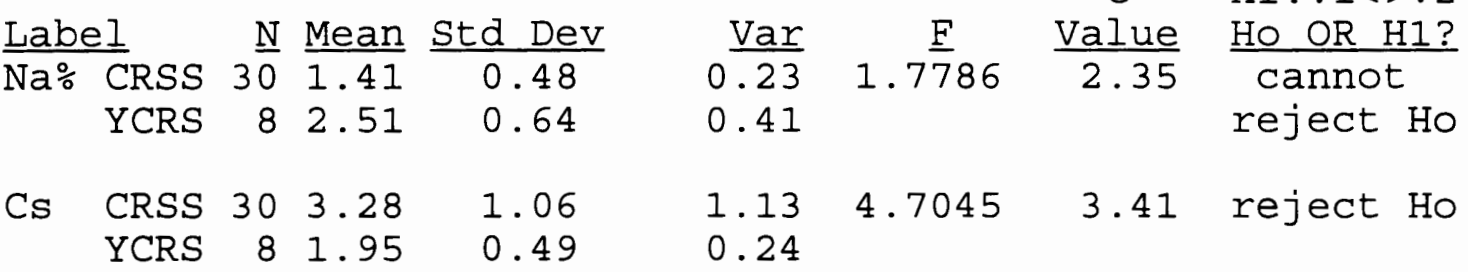

$\mathrm{Ba} \quad$ CRSS $30 \quad 594 \quad 103.13 \quad 10636.03$ $\begin{array}{llllll}\text { YCRS } & 8 & 575 & 130.84 & 17119.87\end{array}$

1.60962 .35 cannot reject Ho

$\mathrm{Fe} \%$ CRSS $30 \quad 6.21 \quad 1.09 \quad 1.18$

$4.5483 \quad 3.41$ reject Ho $\begin{array}{llll}\text { YCRS } & 8 & 3.17 & 0.51\end{array}$

0.26

SC CRSS $30 \quad 14.5 \quad 3.07$

$\begin{array}{llll}\text { YCRS } 8 & 10.2 & 1.40\end{array}$

$9.41 \quad 4.7937 \quad 3.41$ reject Ho

$\begin{array}{lllll}\mathrm{Cr} & \text { CRSS } & 30 & 82 & 29.59\end{array}$

$\begin{array}{llll}\text { YCRS } & 8 & 40 & 7.63\end{array}$

$875.77 \quad 15.055 \quad 3.41$ reject Ho 58.17

CO CRSS $30 \quad 16 \quad 5.55$ $\begin{array}{llll}\text { YCRS } & 8 & 13 & 2.65\end{array}$

30.76

4.39693 .41 reject Ho 7.00

Hf CRSS $30 \quad 7.04 \quad 1.48$ $\begin{array}{llll}\text { YCRS } & 8 & 3.48 & 0.46\end{array}$

$2.18 \quad 10.081 \quad 3.41$ reject Ho 0.22

Th CRSS $30 \quad 9.2 \quad 1.90$ $\begin{array}{llll}\text { YCRS } & 8 & 4.9 & 1.36\end{array}$

3.59

1.85

$1.9432 \quad 3.41$

cannot reject Ho

La CRSS $30 \quad 35.2 \quad 8.18$

66.85 YCRS 822.0

3.49 12.21

$5.4746 \quad 3.41$ reject Ho

Ce CRSS $30 \quad 67.0 \quad 14.43 \quad 208.23$ $\begin{array}{lllll}\text { YCRS } & 8 & 39.1 & 6.52 & 42.54\end{array}$

$4.8953 \quad 3.41$ reject Ho

Sm CRSS $\begin{array}{llll}30 & 5.88 & 1.22\end{array}$

YCRS $\quad 8 \quad 3.83$

1.49

0.18

$8.0682 \quad 3.41$ reject Ho

$\begin{array}{lllll}\mathrm{Eu} & \text { CRSS } & 30 & 1.37 & 0.25\end{array}$

YCRS $8 \begin{array}{lll}\text { Y } & 1.03 & 0.12\end{array}$

0.06

0.02

3.94343 .41 reject Ho

Tb CRSS $30 \quad 0.84 \quad 0.13$

$\begin{array}{llll}\text { YCRS } & 8 & 0.54 & 0.07\end{array}$

0.02

2.9842

3.41

cannot

0.01 reject Ho 
Comparison of Columbia River Source Sediments (CRSS) and

High-Alumina Basalt Sediments (HABS)

* F TESTS * *

\begin{tabular}{|c|c|c|c|c|c|c|c|c|}
\hline Labe & & $\underline{N}$ & Mean & Std Dev & $\underline{\text { Var }}$ & $\underline{F}$ & $\begin{array}{c}\mathrm{C}- \\
\text { Value } \\
\end{array}$ & $\begin{array}{r}\mathrm{HO}: \mathrm{V} 1=\mathrm{V} 2 \\
\mathrm{H} 1: \mathrm{V} 1<>\mathrm{V} 2 \\
\text { HO OR H1? }\end{array}$ \\
\hline $\mathrm{Na} \%$ & CRSS & $3 \overline{0}$ & $\overline{1.41}$ & 0.48 & $0 . \overline{23}$ & $5.0 \overline{3} 09$ & 19.45 & cannot \\
\hline & HABS & 3 & 2.42 & 0.21 & 0.05 & & & reject Ho \\
\hline Cs & CRSS & 30 & 3.28 & 1.06 & 1.13 & 8.0245 & 19.45 & cannot \\
\hline & HABS & 3 & 2.03 & 0.37 & 0.14 & & & reject Ho \\
\hline $\mathrm{Ba}$ & CRSS & 30 & 594 & 103.13 & 10636.03 & 9.5650 & 19.45 & cannot \\
\hline & HABS & 3 & 598 & 33.35 & 1111.98 & & & reject Ho \\
\hline $\mathrm{Fe} \%$ & CRSS & 30 & 6.21 & 1.09 & 1.18 & 2.0543 & 19.45 & cannot \\
\hline & HABS & 3 & 5.34 & 0.76 & 0.57 & & & reject Ho \\
\hline Sc & CRSS & 30 & 14.5 & 3.07 & 9.41 & 14.998 & 19.45 & cannot \\
\hline & HABS & 3 & 18.1 & 0.79 & 0.63 & & & reject Ho \\
\hline $\mathrm{Cr}$ & CRSS & 30 & 82 & 29.59 & 875.77 & 3.7712 & 19.45 & cannot \\
\hline & HABS & 3 & 55 & 15.24 & 232.23 & & & reject Ho \\
\hline $\mathrm{CO}$ & CRSS & 30 & 16 & 5.55 & 30.76 & 1.4967 & 19.45 & cannot \\
\hline & HABS & 3 & 23 & 4.53 & 20.55 & & & reject Ho \\
\hline $\mathrm{Hf}$ & CRSS & 30 & 7.04 & 1.48 & 2.18 & 8.5560 & 19.45 & cannot \\
\hline & HABS & 3 & 3.89 & 0.50 & 0.25 & & & reject Ho \\
\hline Th & CRSS & 30 & 9.2 & 1.90 & 3.59 & 9.5771 & 19.45 & cannot \\
\hline & HABS & 3 & 4.5 & 0.61 & 0.37 & & & reject Ho \\
\hline La & CRSS & 30 & 35.2 & 8.18 & 66.85 & 5.9004 & 19.45 & cannot \\
\hline & HABS & 3 & 22.4 & 3.37 & 11.33 & & & reject Ho \\
\hline $\mathrm{Ce}$ & CRSS & 30 & 67.0 & 14.43 & 208.23 & 3.6216 & 19.45 & cannot \\
\hline & HABS & 3 & 44.0 & 7.58 & 57.50 & & & reject Ho \\
\hline $\mathrm{Sm}$ & CRSS & 30 & 5.88 & 1.22 & 1.49 & 3.1878 & 19.45 & cannot \\
\hline & HABS & 3 & 5.01 & 0.68 & 0.47 & & & reject Ho \\
\hline Eu & CRSS & 30 & 1.37 & 0.25 & 0.060 & 1.0225 & 19.45 & cannot \\
\hline & HABS & 3 & 1.50 & 0.24 & 0.059 & & & reject Ho \\
\hline $\mathrm{Tb}$ & CRSS & 30 & 0.84 & 0.13 & 0.02 & 2.8640 & 19.45 & cannot \\
\hline & HABS & 3 & 0.76 & 0.08 & 0.01 & & & reject Ho \\
\hline
\end{tabular}


Comparison of Columbia River Source Sediments (CRSS) and

High-Alumina Basalt Sediments (HABS)

* * T TESTS

$\mathrm{HO}: \mathrm{X} 1=\mathrm{X} 2$

$\mathrm{C}-\mathrm{H} 1: \mathrm{X} 1<>\mathrm{X} 2$

$\frac{\text { Label }}{\text { Na\% CRSS }} 3 \frac{\mathrm{N}}{30} \frac{\text { Mean }}{1.41} \frac{\mathrm{Std} \text { Dev }}{0.48} \quad \underline{\mathrm{Sp}}$ Se $\underline{\mathrm{T}} \frac{\text { Value Ho OR HI? }}{+/-}$

$\begin{array}{lllll}0.47 & 0.28 & -3.57 & 2.042 & \text { reject Ho }\end{array}$

$\begin{array}{llll}\text { HABS } & 3 & 2.42 & 0.21\end{array}$

$+1-\quad$ cannot

Cs CRSS $30 \quad 3.28 \quad 1.06$

$\begin{array}{llll}\text { HABS } & 3 & 2.03 & 0.37\end{array}$

$1.03 \quad 0.62$

1.99

2.042 reject Ho

$\mathrm{Ba}$ CRSS $30 \quad 594 \quad 103.13$

+ - cannot

$\begin{array}{lllllllll}\text { HABS } & 3 & 598 & 33.35 & 100.11 & 60.62 & -0.06 & 2.042 & \text { reject Ho }\end{array}$

$\mathrm{Fe} \% \mathrm{CRSS} 30 \quad 6.21 \quad 1.09$

$\begin{array}{llll}\text { HABS } & 3 & 5.34 & 0.76\end{array}$

$1.07 \quad 0.65 \quad 1.342 .042$ reject Ho

SC CRSS $30 \quad 14.5 \quad 3.07$

$\begin{array}{llll}\text { HABS } & 3 & 18.1 & 0.79\end{array}$

$+1-$ cannot

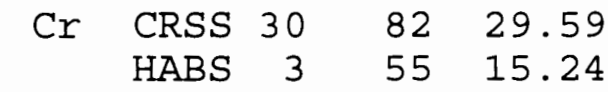

$\begin{array}{lrrrr}\text { Cr } & \text { CRSS } & 30 & 82 & 29.59 \\ \text { HABS } & 3 & 55 & 15.24\end{array}$

$2.97 \quad 1.80-1.982 .042$ reject Ho

$28.88 \quad 17.49 \quad 1.582 .042$ reject Ho

CO CRSS $30 \quad 16 \quad 5.55$

$\begin{array}{llll}\text { HABS } & 3 & 23 & 4.53\end{array}$

$\begin{array}{lllll}5.49 & 3.32 & -2.14 & 2.042 & \text { reject Ho }\end{array}$

Hf CRSS $30 \quad 7.04 \quad 1.48$

$\begin{array}{llll}\text { HABS } & 3 & 3.89 & 0.50\end{array}$

$+1-$

$\begin{array}{llll}1.43 & 0.87 & 3.62 & 2.042 \\ \text { reject Ho }\end{array}$

Th CRSS $30 \quad 9.2 \quad 1.90$ $\begin{array}{llll}\text { HABS } & 3 & 4.5 & 0.61\end{array}$

$+/-$

$\begin{array}{llll}1.84 & 1.11 & 4.22 & 2.042 \text { reject Ho }\end{array}$

La CRSS $30 \quad 35.2 \quad 8.18$ $\begin{array}{llll}\text { HABS } & 3 & 22.4 & 3.37\end{array}$

$+/-$

$\begin{array}{llll}7.95 & 4.82 & 2.642 .042 \text { reject Ho }\end{array}$

Ce CRSS $30 \quad 67.0 \quad 14.43$

$\begin{array}{llll}\text { HABS } & 3 & 44.0 & 7.58\end{array}$

$\begin{array}{llll}14.09 & 8.53 & 2.67 & 2.042 \text { reject Ho }\end{array}$

Sm CRSS $30 \quad 5.88 \quad 1.22$

$\begin{array}{llll}\text { HABS } & 3 & 5.01 & 0.68\end{array}$

$\begin{array}{llll}1.19 & 0.72 & 1.21 & 2.042 \\ \text { reject Ho }\end{array}$

Eu CRSS $30 \quad 1.37 \quad 0.25$

HABS $3 \quad 1.50 \quad 0.24$

$\begin{array}{lllll}0.25 & 0.15 & -0.90 & 2.042 & \text { reject Ho }\end{array}$

Tb CRSS $30 \quad 0.84 \quad 0.13$ $\begin{array}{llll}\text { HABS } & 3 & 0.76 & 0.08\end{array}$ 1.092 .042 reject Ho 
Comparison of Columbia River Source Sediments (CRSS) and

Episodic Cascadian Volcanic Sediments (ECVS)

** F TESTS

\begin{tabular}{|c|c|c|c|c|c|c|c|c|}
\hline Labe & & $\underline{\mathrm{N}}$ & Mean & Std Dev & Var & $\underline{F}$ & $\begin{array}{c}\text { C- } \\
\text { Value } \\
\end{array}$ & $\begin{array}{r}\mathrm{HO}: \mathrm{VI}=\mathrm{V} 2 \\
\mathrm{H} 1: \mathrm{VI}<>\mathrm{V} 2 \\
\mathrm{Ho} \text { OR HI? }\end{array}$ \\
\hline $\mathrm{Na} \%$ & $\begin{array}{l}\text { CRSS } \\
\text { ECVS }\end{array}$ & $\begin{array}{r}3 \overline{0} \\
7\end{array}$ & $\begin{array}{l}1.41 \\
1.61\end{array}$ & $\begin{array}{l}0.48 \\
0.81\end{array}$ & $\begin{array}{l}0 . \overline{23} \\
0.66\end{array}$ & $2.8 \overline{4} 08$ & 2.43 & reject Ho \\
\hline Cs & $\begin{array}{l}\text { CRSS } \\
\text { ECVS }\end{array}$ & $\begin{array}{r}30 \\
7\end{array}$ & $\begin{array}{l}3.28 \\
1.59\end{array}$ & $\begin{array}{l}1.06 \\
0.71\end{array}$ & $\begin{array}{l}1.13 \\
0.50\end{array}$ & 2.2461 & 3.84 & $\begin{array}{l}\text { cannot } \\
\text { reject Ho }\end{array}$ \\
\hline $\mathrm{Ba}$ & $\begin{array}{l}\text { CRSS } \\
\text { ECVS }\end{array}$ & $\begin{array}{r}30 \\
7\end{array}$ & $\begin{array}{l}594 \\
380\end{array}$ & $\begin{array}{r}103.13 \\
96.27\end{array}$ & $\begin{array}{r}10636.03 \\
9267.60\end{array}$ & 1.1477 & 3.84 & $\begin{array}{l}\text { cannot } \\
\text { reject Ho }\end{array}$ \\
\hline $\mathrm{Fe} \%$ & $\begin{array}{l}\text { CRSS } \\
\text { ECVS }\end{array}$ & $\begin{array}{r}30 \\
7\end{array}$ & $\begin{array}{l}6.21 \\
5.82\end{array}$ & $\begin{array}{l}1.09 \\
2.12\end{array}$ & $\begin{array}{l}1.18 \\
4.48\end{array}$ & 3.8009 & 2.43 & reject $\mathrm{Ho}$ \\
\hline SC & $\begin{array}{l}\text { CRSS } \\
\text { ECVS }\end{array}$ & $\begin{array}{r}30 \\
7\end{array}$ & $\begin{array}{l}14.5 \\
17.6\end{array}$ & $\begin{array}{l}3.07 \\
6.04\end{array}$ & $\begin{array}{r}9.41 \\
36.52\end{array}$ & 3.8790 & 2.43 & reject Ho \\
\hline $\mathrm{Cr}$ & $\begin{array}{l}\text { CRSS } \\
\text { ECVS }\end{array}$ & $\begin{array}{r}30 \\
7\end{array}$ & $\begin{array}{r}82 \\
120\end{array}$ & $\begin{array}{l}29.59 \\
39.76\end{array}$ & $\begin{array}{r}875.77 \\
1580.94\end{array}$ & 1.8052 & 2.43 & $\begin{array}{l}\text { cannot } \\
\text { reject Ho }\end{array}$ \\
\hline Co & $\begin{array}{l}\text { CRSS } \\
\text { ECVS }\end{array}$ & $\begin{array}{r}30 \\
7\end{array}$ & $\begin{array}{l}16 \\
25\end{array}$ & $\begin{array}{l}5.55 \\
9.25\end{array}$ & $\begin{array}{l}30.76 \\
85.65\end{array}$ & 2.7843 & 2.43 & reject Ho \\
\hline $\mathrm{Hf}$ & $\begin{array}{l}\text { CRSS } \\
\text { ECVS }\end{array}$ & $\begin{array}{r}30 \\
7\end{array}$ & $\begin{array}{l}7.04 \\
2.47\end{array}$ & $\begin{array}{l}1.48 \\
0.52\end{array}$ & $\begin{array}{l}2.18 \\
0.27\end{array}$ & 7.9531 & 3.84 & reject Ho \\
\hline Th & $\begin{array}{l}\text { CRSS } \\
\text { ECVS }\end{array}$ & $\begin{array}{r}30 \\
7\end{array}$ & $\begin{array}{l}9.2 \\
2.8\end{array}$ & $\begin{array}{l}1.90 \\
1.35\end{array}$ & $\begin{array}{l}3.59 \\
1.83\end{array}$ & 1.9635 & 3.84 & $\begin{array}{l}\text { cannot } \\
\text { reject Ho }\end{array}$ \\
\hline La & $\begin{array}{l}\text { CRSS } \\
\text { ECVS }\end{array}$ & $\begin{array}{r}30 \\
7\end{array}$ & $\begin{array}{l}35.2 \\
11.8\end{array}$ & $\begin{array}{l}8.18 \\
2.85\end{array}$ & $\begin{array}{r}66.85 \\
8.15\end{array}$ & 8.2025 & 3.84 & reject Ho \\
\hline $\mathrm{Ce}$ & $\begin{array}{l}\text { CRSS } \\
\text { ECVS }\end{array}$ & $\begin{array}{r}30 \\
7\end{array}$ & $\begin{array}{l}67.0 \\
22.7\end{array}$ & $\begin{array}{r}14.43 \\
5.69\end{array}$ & $\begin{array}{r}208.23 \\
32.42\end{array}$ & 6.4226 & 3.84 & reject Ho \\
\hline Sm & $\begin{array}{l}\text { CRSS } \\
\text { ECVS }\end{array}$ & $\begin{array}{r}30 \\
7\end{array}$ & $\begin{array}{l}5.88 \\
2.91\end{array}$ & $\begin{array}{l}1.22 \\
0.45\end{array}$ & $\begin{array}{l}1.49 \\
0.20\end{array}$ & 7.3160 & 3.84 & reject Ho \\
\hline Eu & $\begin{array}{l}\text { CRSS } \\
\text { ECVS }\end{array}$ & $\begin{array}{r}30 \\
7\end{array}$ & $\begin{array}{l}1.37 \\
0.99\end{array}$ & $\begin{array}{l}0.25 \\
0.17\end{array}$ & $\begin{array}{l}0.060 \\
0.029\end{array}$ & 2.0450 & 3.84 & $\begin{array}{l}\text { cannot } \\
\text { reject Ho }\end{array}$ \\
\hline$\Gamma \mathrm{b}$ & $\begin{array}{l}\text { CRSS } \\
\text { ECVS }\end{array}$ & $\begin{array}{r}30 \\
7\end{array}$ & $\begin{array}{l}0.84 \\
0.53\end{array}$ & $\begin{array}{l}0.13 \\
0.10\end{array}$ & $\begin{array}{l}0.02 \\
0.01\end{array}$ & 1.7013 & 3.84 & $\begin{array}{l}\text { cannot } \\
\text { reject Ho }\end{array}$ \\
\hline
\end{tabular}


Comparison of Columbia River Basalt Group Sediments (CRBS) and

Reed Island Ashes (RIA)

* F TESTS

$\mathrm{Ho}: \mathrm{V} 1=\mathrm{V} 2$

$\mathrm{C}-\mathrm{H} 1: \mathrm{V} 1<\mathrm{V} 2$

\begin{tabular}{|c|c|c|c|c|c|c|c|c|}
\hline \multirow{2}{*}{$\frac{\text { Labe }}{\mathrm{Na} \%}$} & & $\underline{\mathrm{N}}$ & Mean & Std Dev & Var & \multirow{3}{*}{$22 . \frac{F}{875}$} & Value & Ho OR HI? \\
\hline & CRBS & $\overline{3}$ & 1.50 & 2.04 & $4 \overline{16}$ & & $1 \overline{99.50}$ & cannot \\
\hline & RIA & 2 & 3.07 & 0.43 & 0.18 & & & reject $\mathrm{H}$ \\
\hline Cs & CRBS & 3 & 2.09 & 1.55 & 2.41 & 3.7274 & 199.50 & cannot \\
\hline & RIA & 2 & 1.59 & 0.80 & 0.65 & & & reject \\
\hline
\end{tabular}

$\begin{array}{lllllllll}\mathrm{Ba} & \mathrm{CRBS} & 3 & 574 & 41.61 & 1731.72 & 2.2768 & 18.51 & \text { cannot }\end{array}$ RIA $248962.79 \quad 3942.72 \quad$ reject Ho

Fe\% CRBS $311.0 \quad 1.02$ $\begin{array}{llll}\text { RIA } & 2 & 2.41 & 0.22\end{array}$

$1.05 \quad 21.002 \quad 199.50$

cannot reject Ho

$\mathrm{SC}$ CRBS $346.0 \quad 9.10$

$\begin{array}{rrr}82.83 & 142.98 & 199.50 \\ 0.58 & \end{array}$

cannot $\begin{array}{llll}\text { RIA } 2 & 8.5 & 0.76\end{array}$

reject $\mathrm{Ho}$

$\begin{array}{lllll}C r & \text { CRBS } & 3 & 50 & 22.36\end{array}$ $\begin{array}{llll}\text { RIA } & 2 & 23 & 1.19\end{array}$

500.00

351.79199 .50

reject $\mathrm{Ho}$ 1.42

$\begin{array}{lllll}\text { CO } & \text { CRBS } & 3 & 32 & 2.51\end{array}$

6.31

$12.350 \quad 199.50$

cannot $\begin{array}{llll}\text { RIA } & 2 & 10 & 0.71\end{array}$

0.51

reject $\mathrm{Ho}$

Hf CRBS $37.61 \quad 1.81$

$\begin{array}{lll}3.27 & 30.966 & 199.50\end{array}$

cannot

$\begin{array}{llll}\text { RIA } & 2 & 4.13 & 0.33\end{array}$

0.11

reject $\mathrm{HO}$

Th CRBS $3 \quad 8.0 \quad 3.69$

$\begin{array}{llll}\text { RIA } & 2 & 4.3 & 0.71\end{array}$

$13.64 \quad 27.000 \quad 199.50$

0.51

cannot

reject $\mathrm{Ho}$

La CRBS $3 \quad 43.4 \quad 7.14$

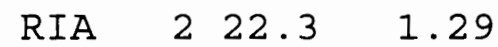

$\begin{array}{lll}51.02 & 30.736 \quad 199.50\end{array}$

cannot reject Ho

Ce CRBS $3 \quad 90.9 \quad 64.60$

4172.58

$90.853 \quad 199.50$

cannot RIA $240.2 \quad 6.78$

45.93

reject Ho

$\begin{array}{lllll}\mathrm{Sm} & \mathrm{CRBS} & 3 & 10.7 & 2.59\end{array}$

$\begin{array}{lll}6.68 & 30.544 & 199.50\end{array}$

cannot

RIA 23.96

0.47

0.22

reject $\mathrm{HO}$

$\begin{array}{lllll}\text { Eu CRBS } & 3 & 3.05 & 0.72\end{array}$

0.52 RIA 21.05

0.02

0.0005

1136.3199 .50

reject $\mathrm{HO}$

Tb CRBS 31.62

0.19

0.04

5.9719199 .50

cannot

reject Ho 
Comparison of Columbia River Basalt Group Sediments (CRBS) and

Reed Island Ashes (RIA)

* * T TESTS **

$\mathrm{HO}: \mathrm{X} 1=\mathrm{X} 2$

$\mathrm{C}-\mathrm{H} 1: \mathrm{X} 1<\mathrm{X} 2$

$\frac{\text { Label }}{\text { Na\% CRBS }} \frac{\mathrm{N}}{3} \frac{\text { Mean }}{1.50} \frac{\text { Std Dev }}{2.04} \quad \mathrm{Sp} \quad \mathrm{Se} \quad \underline{\mathrm{T}} \frac{\text { Value Ho OR H1? }}{+/-}$

$\begin{array}{llllllll}\text { RIA } & 2 & 3.07 & 0.43 & 1.68 & 1.54 & -1.03 & 3.182 \\ \text { reject Ho }\end{array}$

Cs CRBS $32.09 \quad 1.55$

$\begin{array}{llll}\text { RIA } & 2 & 1.59 & 0.80\end{array}$

$+/-$ cannot

$\begin{array}{lllll}1.35 & 1.23 & 0.41 & 3.182 & \text { reject Ho }\end{array}$

Ba CRBS $3 \quad 574 \quad 41.61$ $\begin{array}{llll}\text { RIA } & 2 & 489 & 62.79\end{array}$

$+1-$ cannot

$49.6945 .36 \quad 1.883 .182$ reject Ho

Fe\% CRBS 311.0

1. 02

0.22

$+1-$

RIA 22.41

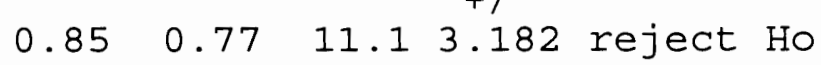

SC CRBS 346.0

9.10

$+1-$

$\begin{array}{lll}\text { RIA } & 2 & 8.5\end{array}$

0.76

7.446 .80

Cr CRBS $3 \quad 50 \quad 22.36$

$\begin{array}{llll}\text { RIA } & 2 & 23 & 1.19\end{array}$

$+/$ cannot

$18.27 \quad 16.68 \quad 1.67 \quad 3.182$ reject Ho

$\begin{array}{lllll}\text { CO CRBS } & 3 & 32 & 2.51\end{array}$

$\begin{array}{llll}\text { RIA } & 2 & 10 & 0.71\end{array}$

$+1-$

$2.091 .91 \quad 11.53 .182$ reject Ho

HE CRBS $37.61 \quad 1.81$

$\begin{array}{llll}\text { RIA } & 2 & 4.13 & 0.33\end{array}$

$+1-$ cannot

$1.491 .36 \quad 2.563 .182$ reject Ho

Th CRBS $38.0 \quad 3.69$

$\begin{array}{llll}\text { RIA } & 2 & 4.3 & 0.71\end{array}$

$+1-$ cannot

$\begin{array}{llll}3.04 & 2.78 & 1.33 & 3.182 \\ & \text { reject } \mathrm{Ho}\end{array}$

Ia CRBS $343.4 \quad 7.14$

$\begin{array}{llll}\text { RIA } & 2 & 22.3 & 1.29\end{array}$

$+1-$

$5.88 \quad 5.37 \quad 3.943 .182$ reject Ho

Ce CRBS $390.9 \quad 64.60$

$\begin{array}{llll}\text { RIA } & 2 & 40.2 & 6.78\end{array}$

$+1-$ cannot

$52.8948 .28 \quad 1.05 \quad 3.182$ reject Ho

$\begin{array}{lllll}\mathrm{Sm} & \mathrm{CRBS} & 3 & 10.7 & 2.59\end{array}$ $\begin{array}{llll}\text { RIA } & 2 & 3.96 & 0.47\end{array}$

$+1-$

$2.13 \quad 1.94 \quad 3.453 .182$ reject Ho

Eu CRBS $3 \quad 3.05$

0.72

0.02

$+1-$

$\begin{array}{lll}\text { RIA } & 21.05\end{array}$

$\begin{array}{llll}0.59 & 0.54 & 3.71 & 3.182 \\ & \text { reject Ho }\end{array}$

Tb CRBS $31.62 \quad 0.19$

$\begin{array}{lll}\text { RIA } & 2 & 0.52\end{array}$

0.08

$+1-$

$0.170 .15 \quad 7.26 \quad 3.182$ reject Ho 
Comparison of Columbia River Basalt Group Sediments (CRBS) and

Young Columbia River Sediments (YCRS)

** F TESTS

$\mathrm{HO}: \mathrm{V} 1=\mathrm{V} 2$

$\mathrm{C}-\mathrm{H} 1: \mathrm{V} 1<>\mathrm{V} 2$

$\begin{array}{rlllllll}\text { Label } & \frac{N}{N} \text { Mean } & \frac{\text { Std Dev }}{2.04} & \frac{\text { Var }}{.16} & 10.126 & \frac{F}{4.74} & \frac{\text { Value }}{\text { Na }} & \frac{\text { Ho OR H1? }}{\text { reject Ho }} \\ \text { YCRS } & 8 & 2.51 & 0.64 & 0.41 & & & \end{array}$

Cs CRBS $32.09 \quad 1.55 \quad 2.41 \quad 10.055 \quad 4.74$ reject Ho

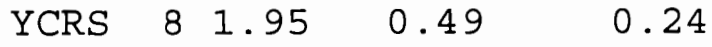

Ba CRBS $3 \quad 574 \quad 41.61 \quad 1731.72 \quad 9.8861 \quad 19.35$ reject Ho $\begin{array}{lllll}\text { YCRS } & 8 & 575 & 130.84 & 17119.87\end{array}$

Fe\% CRBS $311.0 \quad 1.02$ $\begin{array}{llll}\text { YCRS } & 8 & 3.17 & 0.51\end{array}$

SC CRBS $3 \quad 46.0 \quad 9.10$ $\begin{array}{llll}\text { YCRS } 8 & 10.2 \quad 1.40\end{array}$

$\begin{array}{lllll}\text { Cr } & \text { CRBS } & 3 & 50 & 22.36\end{array}$ $\begin{array}{llll}\text { YCRS } & 8 & 40 & 7.63\end{array}$

$\begin{array}{lllll}\text { Co } & \text { CRBS } & 3 & 32 & 2.51\end{array}$ $\begin{array}{llll}\text { YCRS } & 8 & 13 & 2.65\end{array}$

HE CRBS $3 \quad 7.61 \quad 1.81$ $\begin{array}{lll}\text { YCRS } & 8 & 3.48\end{array}$
1.05

0.26

4.0420

82.83

1.96

42.179

$500.00 \quad 8.5951$ 58.17

6.31

7.00

1.1085

3.27

0.22

Th CRBS $3 \quad 8.0 \quad 3.69$ $\begin{array}{llll}\text { YCRS } & 8 & 4.9 & 1.36\end{array}$

$\begin{array}{lllll}\text { La } & \text { CRBS } & 3 & 43.4 & 7.14\end{array}$ $\begin{array}{llll}\text { YCRS } & 8 & 22.0 & 3.49\end{array}$

Ce CRBS $3 \quad 90.9 \quad 64.60$ $\begin{array}{llll}\text { YCRS } & 8 & 39.1 & 6.52\end{array}$

$\begin{array}{lllll}\text { Sm } & \text { CRBS } & 3 & 10.7 & 2.59\end{array}$ $\begin{array}{llll}\text { YCRS } & 8 & 3.83 & 0.43\end{array}$

$\begin{array}{lllll}\text { Eu } & \text { CRBS } & 3 & 3.05 & 0.72\end{array}$

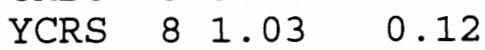

$\begin{array}{lllll}\text { Tb } & \text { CRBS } & 3 & 1.62 & 0.19\end{array}$ $\begin{array}{llll}\text { YCRS } & 8 & 0.54 & 0.07\end{array}$

\section{$13.64 \quad 7.3794$} 1.85

51.02 12.21

$4172.58 \quad 98.092$ 42.54

$6.68 \quad 36.158$

0.18

0.02

$0.04 \quad 6.8013$ 0.01
$0.52 \quad 34.097$
4.74 cannot reject Ho

4.74 reject Ho 4.74 reject Ho 19.35

cannot reject Ho

4.74 reject Ho 4.74 reject Ho 4.74 cannot reject Ho 4.74 reject Ho 4.74 reject Ho 4.74 reject Ho 4.74 reject Ho 
Comparison of Columbia River Basalt Group Sediments (CRBS) and

High-Alumina Basalt Sediments (HABS)

** F TESTS **

$\mathrm{Ho}: \mathrm{V} 1=\mathrm{V} 2$

$\mathrm{C}-\mathrm{H} 1: \mathrm{V} 1<>\mathrm{V} 2$

$\begin{array}{llllllll}\text { Label } & \frac{N}{3} \frac{\text { Mean }}{1.50} & \frac{\text { Std Dev }}{2.04} & \frac{\text { Var }}{4.16} & 90.614 & \frac{F}{19.00} & \frac{\text { Value OR H1? }}{\text { reject Ho }} \\ \text { HABS } & 3 & 2.42 & 0.21 & 0.05 & & & \end{array}$

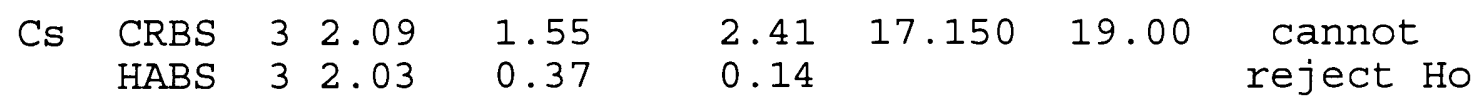

$\begin{array}{lllllllll}\mathrm{Ba} & \mathrm{CRBS} & 3 & 574 & 41.61 & 1731.72 & 1.5573 & 19.00 & \text { cannot }\end{array}$

$\begin{array}{lllll}\text { HABS } & 3 & 598 & 33.35 & 1111.98 \\ \end{array}$

$\mathrm{Fe} \% \mathrm{CRBS} \quad 3 \quad 11.0 \quad 1.02 \quad 1.05 \quad 1.8256 \quad 19.00 \quad$ cannot

$\begin{array}{lllll}\text { HABS } & 3 & 5.34 & 0.76 & 0.57\end{array}$

$\begin{array}{rrrrrrrr}\text { SC CRBS } & 3 & 46.0 & 9.10 & 82.83 & 131.96 & 19.00 & \text { reject Ho } \\ \text { HABS } & 3 & 18.1 & 0.79 & 0.63 & & & \end{array}$

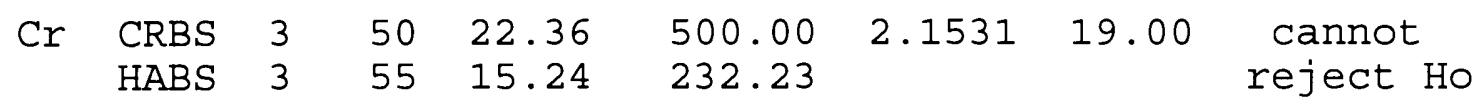

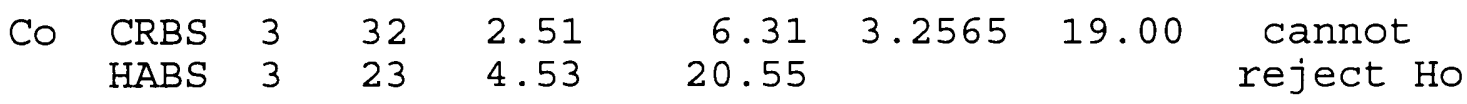

$\begin{array}{llllllll}\text { Hf } & \text { CRBS } & 3 & 7.61 & 1.81 & 3.27 & 12.857 & 19.00 \\ \end{array}$

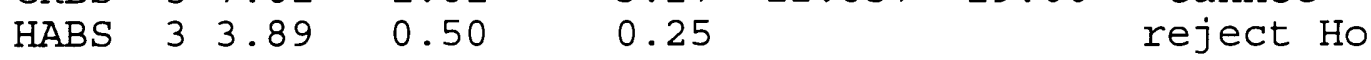

Th CRBS $3 \quad 8.0 \quad 3.69 \quad 13.64 \quad 36.370 \quad 19.00$ reject Ho $\begin{array}{lllll}\text { HABS } & 3 & 4.5 & 0.61 & 0.37\end{array}$

La CRBS $3 \quad 43.4 \quad 7.14$

$\begin{array}{llll}\text { HABS } & 3 & 22.4 & 3.37\end{array}$

51.02

11.33

$4.5030 \quad 19.00$ cannot reject Ho

Ce CRBS $3 \quad 90.9 \quad 64.60 \quad 4172.58 \quad 72.570 \quad 19.00$ reject Ho HABS $\quad 3 \quad 44.0 \quad 7.58 \quad 57.50$

Sm CRBS $\quad 3 \quad 10.7$

2.59

6.68

HABS $3 \quad 5.01$

0.68

0.47

14.286

19.00

cannot reject Ho

$\mathrm{Eu}$ CRBS $3 \quad 3.05$

$0.72 \quad 0.52$

8.8410

19.00

cannot

HABS 31.50

0.24

0.06

reject Ho

$\begin{array}{lllll}\text { Tb } & \text { CRBS } & 3 & 1.62 & 0.19 \\ \text { HABS } & 3 & 0.76 & 0.08\end{array}$

0.04

6.5273

19.00

cannot reject Ho 
Comparison of Columbia River Basalt Group Sediments (CRBS) and

Episodic Cascadian Volcanic Sediments (ECVS)

** F TESTS

\begin{tabular}{|c|c|c|c|c|c|c|c|c|}
\hline & & & & & & & $\mathrm{C}-$ & $\begin{array}{r}\mathrm{Ho}: \mathrm{V} 1=\mathrm{V} 2 \\
\mathrm{H} 1: \mathrm{V} 1<>\mathrm{V} 2\end{array}$ \\
\hline Labe & & $\underline{N}$ & Mean & $\underline{\text { Std Dev }}$ & $\underline{\operatorname{Var}}$ & $\underline{F}$ & Value & $\underline{\mathrm{HO}}$ OR H1? \\
\hline $\mathrm{Na} \%$ & CRBS & $\overline{3}$ & $\overline{1.50}$ & 2.04 & $4 . \overline{16}$ & $6.3 \overline{4} 02$ & 5.14 & $\overline{\text { reject } \mathrm{Ho}}$ \\
\hline & ECVS & 7 & 1.61 & 0.81 & 0.66 & & & \\
\hline $\mathrm{Cs}$ & CRBS & 3 & 2.09 & 1.55 & 2.41 & 4.8004 & 5.14 & cannot \\
\hline & ECVS & 7 & 1.59 & 0.71 & 0.50 & & & reject Ho \\
\hline $\mathrm{Ba}$ & CRBS & 3 & 574 & 41.61 & 1731.72 & 5.3517 & 19.33 & cannot \\
\hline & ECVS & 7 & 380 & 96.27 & 9267.60 & & & reject Ho \\
\hline $\mathrm{Fe} \%$ & CRBS & 3 & 11.0 & 1.02 & 1.05 & 4.2770 & 19.33 & cannot \\
\hline & ECVS & 7 & 5.82 & 2.12 & 4.48 & & & reject Ho \\
\hline SC & CRBS & 3 & 46.0 & 9.10 & 82.83 & 2.2683 & 5.14 & cannot \\
\hline & ECVS & 7 & 17.6 & 6.04 & 36.52 & & & reject Ho \\
\hline $\mathrm{Cr}$ & CRBS & 3 & 50 & 22.36 & 500.00 & 3.1619 & 19.33 & cannot \\
\hline & ECVS & 7 & 120 & 39.76 & 1580.94 & & & reject Ho \\
\hline $\mathrm{CO}$ & CRBS & 3 & 32 & 2.51 & 6.31 & 13.571 & 19.33 & cannot \\
\hline & ECVS & 7 & 25 & 9.25 & 85.65 & & & reject Ho \\
\hline $\mathrm{Hf}$ & CRBS & 3 & 7.61 & 1.81 & 3.27 & 11.951 & 5.14 & reject Ho \\
\hline & ECVS & 7 & 2.47 & 0.52 & 0.27 & & & \\
\hline Th & CRBS & 3 & 8.0 & 3.69 & 13.64 & 7.4564 & 5.14 & reject Ho \\
\hline & ECVS & 7 & 2.8 & 1.35 & 1.83 & & & \\
\hline La & CRBS & 3 & 43.4 & 7.14 & 51.02 & 6.2598 & 5.14 & reject Ho \\
\hline & ECVS & 7 & 11.8 & 2.85 & 8.15 & & & \\
\hline $\mathrm{Ce}$ & CRBS & 3 & 90.9 & 64.60 & 4172.58 & 128.70 & 5.14 & reject Ho \\
\hline & ECVS & 7 & 22.7 & 5.69 & 32.42 & & & \\
\hline Sm & CRBS & 3 & 10.7 & 2.59 & 6.68 & 32.787 & 5.14 & reject Ho \\
\hline & ECVS & 7 & 2.91 & 0.45 & 0.20 & & & \\
\hline Eu & CRBS & 3 & 3.05 & 0.72 & 0.52 & 17.682 & 5.14 & reject Ho \\
\hline & ECVS & 7 & 0.99 & 0.17 & 0.03 & & & \\
\hline $\mathrm{Tb}$ & CRBS & 3 & 1.62 & 0.19 & 0.04 & 3.8774 & 5.14 & cannot \\
\hline & ECVS & 7 & 0.53 & 0.10 & 0.01 & & & reject Ho \\
\hline
\end{tabular}


Comparison of Reed Island Ashes (RIA) and

Young Columbia River Sediments (YCRS)

** F TESTS

$\mathrm{Ho}: \mathrm{VI}=\mathrm{V} 2$

$\mathrm{C}-\mathrm{H} 1: \mathrm{V} 1<>\mathrm{V} 2$

$\frac{\text { Label }}{\text { Na\% RIA }} \quad \frac{N}{2} \frac{\text { Mean }}{3.07} \frac{\text { Std Dev }}{0.43}$ YCRS $82.51 \quad 0.64$

Cs RIA $21.59 \quad 0.80$ $\begin{array}{llll}\text { YCRS } & 8 & 1.95 & 0.49\end{array}$

$\begin{array}{llllll}\mathrm{Ba} & \mathrm{RIA} & 2 & 489 & 62.79 & 3942.72\end{array}$ $\begin{array}{lllll}\text { YCRS } & 8 & 575 & 130.84 & 17119.87\end{array}$

$\begin{array}{llll}\text { Fe\% RIA } 2 & 2.41 & 0.22\end{array}$ $\begin{array}{llll}\text { YCRS } & 8 & 3.17 & 0.51\end{array}$

$\begin{array}{lllll}\mathrm{SC} & \mathrm{RIA} & 2 & 8.5 & 0.76\end{array}$ $\begin{array}{llll}\text { YCRS } & 8 & 10.2 & 1.40\end{array}$

$\begin{array}{lllll}\text { Cr RIA } & 2 & 23 & 1.19\end{array}$ $\begin{array}{llll}\text { YCRS } & 8 & 40 & 7.63\end{array}$

Co RIA $2 \quad 10 \quad 0.71$ $\begin{array}{llll}\text { YCRS } & 8 & 13 & 2.65\end{array}$

Hf RIA $24.13 \quad 0.33$ $\begin{array}{llll}\text { YCRS } & 8 & 3.48 & 0.46\end{array}$

0.05

0.26

$$
0.58
$$

1.96

1.42 58.17

$$
0.51
$$$$
7.00
$$

$13.690 \quad 236.77$

$$
0.11
$$

0.22

0.51 1.85

1.36

1.29 YCRS $822.0 \quad 3.49$

1.66 12.21

Ce RIA $240.2 \quad 6.78$ $\begin{array}{llll}\text { YCRS } & 8 & 39.1 & 6.52\end{array}$

$45.93 \quad 1.0797$ 42.54

Sm RIA 23.96 YCRS 83.83

0.47

0.43

0.22
0.18

0.02

0.12

0.0005

0.0153

$33.326 \quad 236.77$ YCRS 81.03

0.08

0.07

0.0063

0.0056
2.0441236 .77

1.1838

$4.3421 \quad 236.77$

$5.1960 \quad 236.77$

$3.3899 \quad 236.77$

$40.929 \quad 236.77$ reject Ho

cannot reject Ho

cannot reject Ho

cannot reject Ho

cannot reject Ho

cannot reject $\mathrm{Ho}$ cannot reject Ho

cannot reject Ho

1.1389

5.59 cannot reject Ho 
Comparison of Reed Island Ashes (RIA) and

Young Columbia River sediments (YCRS)

** T TESTS

$\mathrm{HO}: \mathrm{X} 1=\mathrm{X} 2$

$\mathrm{C}-\mathrm{H} 1: \mathrm{X} 1<>\mathrm{X} 2$

$\frac{\text { Label }}{\text { Na\% RIA }} \frac{N}{2} \frac{\text { Mean }}{3.07} \frac{\text { Std Dev }}{0.43} \quad \underline{\text { Sp }}$ Se $\quad \frac{T}{+/-} \frac{\text { Value Ho OR H1? }}{\text { can't }^{\prime}}$

0.620 .491 .162 .306 reject Ho $\begin{array}{llll}\text { YCRS } & 8 & 2.51 & 0.64\end{array}$

$+/-\quad \operatorname{can}^{\prime} t$

Cs RIA $2 \quad 1.59 \quad 0.80$

0.49

0.54

$0.43-0.842 .306$ reject Ho

$\begin{array}{lllll}\mathrm{Ba} & \mathrm{RIA} & 2 & 489 & 62.79\end{array}$

$+1-\quad \operatorname{can}^{\prime} t$ YCRS $8 \quad 575 \quad 130.84 \quad 124.3998 .34 \quad-0.88 \quad 2.306$ reject Ho

Fe\% RIA $22.41 \quad 0.22$

$+1-\quad \operatorname{can}^{\prime} t$

$\begin{array}{llll}\text { YCRS } & 8 & 3.17 & 0.51\end{array}$

$0.480 .38-1.992 .306$ reject Ho

SC RIA $28.5 \quad 0.76$

$+1-\quad \operatorname{can}^{\prime} t$

YCRS $8 \quad 10.2 \quad 1.40$

1.34

$1.06-1.64$

2.306 reject $\mathrm{Ho}$

$\begin{array}{lllll}\text { Cr } & \text { RIA } & 2 & 23 & 1.19\end{array}$

$\begin{array}{llll}\text { YCRS } & 8 & 40 & 7.63\end{array}$

$\begin{array}{lllll}7.15 & 5.65 & -3.12 & 2.306\end{array}$

$+/-$

2.306 reject Ho

$\begin{array}{lllll}\text { Co RIA } & 2 & 10 & 0.71\end{array}$

$\begin{array}{llll}\text { YCRS } & 8 & 13 & 2.65\end{array}$

$2.491 .97-1.782 .306$ reject Ho

HE RIA $24.13 \quad 0.33$

$\begin{array}{llll}\text { YCRS } & 8 & 3.48 & 0.46\end{array}$

$\begin{array}{lllll}0.45 & 0.36 & 1.83 & 2.306 & \text { can't } \\ \text { reject Ho }\end{array}$

$\begin{array}{lllll}\text { Th RIA } & 2 & 4.3 & 0.71\end{array}$

$\begin{array}{llll}\text { YCRS } & 8 & 4.9 & 1.36\end{array}$

$+/-\quad$ can't

$1.301 .02-0.502 .306$ reject Ho

La RIA $222.3 \quad 1.29$

YCRS $822.0 \quad 3.49 \quad 3.30 \quad 2.61 \quad 0.112 .306$ reject Ho

$+1-\quad \operatorname{can}^{\prime} t$

Ce RIA $240.2 \quad 6.78$

YCRS 839.1

6.52

$+1-\quad \operatorname{can}^{\prime} t$

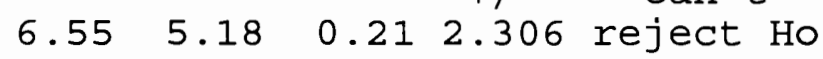

$\begin{array}{lllll}\text { Sm } & \text { RIA } & 2 & 3.96 & 0.47\end{array}$

$\begin{array}{llll}\text { YCRS } & 8 & 3.83 & 0.43\end{array}$

$+1-$

$\begin{array}{llll}0.43 & 0.34 & 0.37 & 2.306 \\ \text { reject Ho }\end{array}$

Eu RIA $21.05 \quad 0.02$

$\begin{array}{llll}\text { YCRS } & 8 & 1.03 & 0.12\end{array}$

$\begin{array}{lllll}0.12 & 0.09 & 0.30 & 2.306 & \text { reject } \\ \text { can't }\end{array}$

$\begin{array}{lllll}\mathrm{Tb} & \mathrm{RIA} & 2 & 0.52 & 0.08\end{array}$ $\begin{array}{llll}\text { YCRS } & 8 & 0.54 & 0.07\end{array}$

$+/-\quad$ can't $0.080 .06-0.222 .306$ reject Ho 
Comparison of Reed Island Ashes (RIA) and

High-Alumina Basalt Sediments. (HABS)

* F TESTS * *

$\mathrm{Ho}: \mathrm{V} 1=\mathrm{V} 2$

$\mathrm{C}-\mathrm{H} 1: \mathrm{V} 1<\mathrm{V} 2$

\begin{tabular}{|c|c|c|c|c|c|c|c|c|}
\hline Labe & & $\underline{\mathrm{N}}$ & Mean & Std Dev & $\underline{\text { Var }}$ & $\underline{F}$ & Value & Ho OR H1? \\
\hline$\overline{\mathrm{Na}} \%$ & $\bar{R} I A$ & $\overline{2}$ & $\overline{3.07}$ & 0.43 & $0 . \overline{18}$ & $3.9 \overline{6} 13$ & $\overline{18.51}$ & cannot \\
\hline & HABS & 3 & 2.42 & 0.21 & 0.05 & & & reject Ho \\
\hline $\mathrm{Cs}$ & RIA & 2 & 1.59 & 0.80 & 0.65 & 4.6011 & 18.51 & cannot \\
\hline & HABS & 3 & 2.03 & 0.37 & 0.14 & & & reject Ho \\
\hline $\mathrm{Ba}$ & RIA & 2 & 489 & 62.79 & 3942.72 & 3.5457 & 18.51 & cannot \\
\hline & HABS & 3 & 598 & 33.35 & 1111.98 & & & reject Ho \\
\hline $\mathrm{Fe} \%$ & RIA & 2 & 2.41 & 0.22 & 0.05 & 11.504 & 199.50 & cannot \\
\hline & HABS & 3 & 5.34 & 0.76 & 0.57 & & & reject Ho \\
\hline $\mathrm{Sc}$ & RIA & 2 & 8.5 & 0.76 & 0.58 & 1.0835 & 199.50 & cannot \\
\hline & HABS & 3 & 18.1 & 0.79 & 0.63 & & & reject Ho \\
\hline $\mathrm{Cr}$ & RIA & 2 & 23 & 1.19 & 1.42 & 163.39 & 199.50 & cannot \\
\hline & HABS & 3 & 55 & 15.24 & 232.23 & & & reject $\mathrm{Ho}$ \\
\hline Co & RIA & 2 & 10 & 0.71 & 0.51 & 40.218 & 199.50 & cannot \\
\hline & HABS & 3 & 23 & 4.53 & 20.55 & & & reject Ho \\
\hline $\mathrm{HE}$ & RIA & 2 & 4.13 & 0.33 & 0.11 & 2.4084 & 199.50 & cannot \\
\hline & HABS & 3 & 3.89 & 0.50 & 0.25 & & & reject Ho \\
\hline $\mathrm{Th}$ & RIA & 2 & 4.3 & 0.71 & 0.51 & 1.3470 & 18.51 & cannot \\
\hline & HABS & 3 & 4.5 & 0.61 & 0.37 & & & reject Ho \\
\hline La & RIA & 2 & 22.3 & 1.29 & 1.66 & 6.8257 & 199.50 & cannot \\
\hline & HABS & 3 & 22.4 & 3.37 & 11.33 & & & reject Ho \\
\hline $\mathrm{Ce}$ & RIA & 2 & 40.2 & 6.78 & 45.93 & 1.2519 & 199.50 & cannot \\
\hline & HABS & 3 & 44.0 & 7.58 & 57.50 & & & reject Ho \\
\hline $\mathrm{Sm}$ & RIA & 2 & 3.96 & 0.47 & 0.22 & 2.1380 & 199.50 & cannot \\
\hline & HABS & 3 & 5.01 & 0.68 & 0.47 & & & reject Ho \\
\hline $\mathrm{Eu}$ & RIA & 2 & 1.05 & 0.02 & 0.0005 & 128.53 & 199.50 & cannot \\
\hline & HABS & 3 & 1.50 & 0.24 & 0.0590 & & & reject $\mathrm{Ho}$ \\
\hline $\mathrm{Tb}$ & RIA & 2 & 0.52 & 0.08 & 0.0063 & 1.0930 & 18.51 & cannot \\
\hline & HABS & 3 & 0.76 & 0.08 & 0.0058 & & & reject Ho \\
\hline
\end{tabular}


Comparison of Reed Island Ashes (RIA)

and

High-Alumina Basalt sediments (HABS)

** T TESTS **

$\mathrm{Ho}: \mathrm{X} 1=\mathrm{X} 2$

C- $\mathrm{H} 1: \mathrm{X} 1<>\mathrm{X} 2$

Label $_{\text {Na\% RIA }} \frac{N}{3.07} \frac{\text { Mean Std Dev }}{0.43} \quad \underline{S p} \quad \underline{\text { Se Value Ho OR HI? }}$

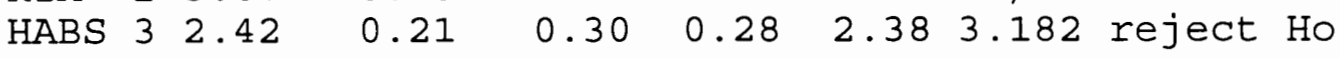

Cs RIA $21.59 \quad 0.80$

$+1-\quad \operatorname{can}^{\prime} t$

$\begin{array}{lllllllll}\text { HABS } & 3 & 2.03 & 0.37 & 0.56 & 0.51 & -0.87 & 3.182 & \text { reject Ho }\end{array}$

Ba RIA $2489 \quad 62.79$

HABS $3 \quad 598 \quad 33.35$

$+/-\quad$ can't $^{\prime}$

$45.34 \quad 41.39-2.643 .182$ reject Ho

Fe\% RIA $22.41 \quad 0.22$

HABS $3 \quad 5.34 \quad 0.76$

$+1-$

$\begin{array}{llll}0.63 & 0.58 & -5.07 & 3.182 \\ \text { reject Ho }\end{array}$

SC RIA $2 \quad 8.5 \quad 0.76$

HABS $318.1 \quad 0.79$

$+1-$

$0.780 .71-13.43 .182$ reject $\mathrm{Ho}$

$\begin{array}{lllll}\text { Cr RIA } & 2 & 23 & 1.19\end{array}$

$+1-\quad \operatorname{can}^{\prime} t$

$\begin{array}{llllllll}\text { HABS } & 3 & 55 & 15.24 & 12.46 & 11.38 & -2.89 & 3.182 \\ \text { reject Ho }\end{array}$

Co RIA $2 \quad 10 \quad 0.71$

HABS $323 \quad 4.53$

$+1-$

$3.723 .40-4.053 .182$ reject Ho

HE RIA $24.13 \quad 0.33$

HABS $3 \quad 3.89 \quad 0.50$

$+/-\quad \operatorname{can}^{\prime} t$

$\begin{array}{llll}0.45 & 0.41 & 0.56 & 3.182 \\ \text { reject Ho }\end{array}$

Th RIA $24.3 \quad 0.71$

HABS $3 \quad 4.5 \quad 0.61$

$+1-\quad \operatorname{can}^{\prime} t$

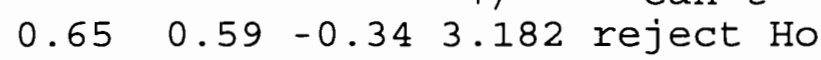

La RIA $222.3 \quad 1.29$

HABS $3 \quad 22.4 \quad 3.37$

$+1-\quad \operatorname{can}^{\prime} t$

$2.852 .60-0.063 .182$ reject Ho

Ce RIA $240.2 \quad 6.78$

$+1-\quad \operatorname{can}^{\prime} t$

$\begin{array}{llllllll}\text { HABS } & 3 & 44.0 & 7.58 & 7.32 & 6.69 & -0.57 & 3.182 \\ \end{array}$

Sm RIA $2 \quad 3.96 \quad 0.47$

$+1-\quad$ can't

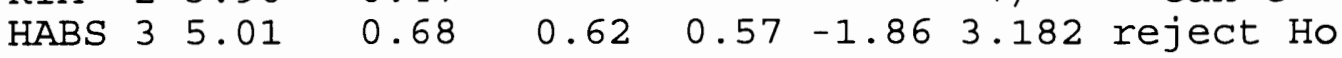

Eu RIA $21.05 \quad 0.02$

$+1-\quad \operatorname{can}^{\prime} t$

HABS $31.50 \quad 0.24$

$\begin{array}{lllll}0.20 & 0.18 & -2.48 & 3.182 & \text { reject Ho }\end{array}$

Tb RIA $20.52 \quad 0.08$

$\begin{array}{lll}0.08 & 0.07 & -3.32 \quad 3.182 \\ +/- & \text { reject Ho }\end{array}$

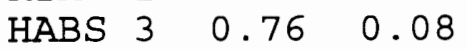


Comparison of Reed Island Ashes (RIA) and

Episodic Cascadian Volcanic Sediments (ECVS)

F TESTS **

$\mathrm{Ho}: \mathrm{V} 1=\mathrm{V} 2$

$\mathrm{C}-\mathrm{H} 1: \mathrm{V} 1<>\mathrm{V} 2$

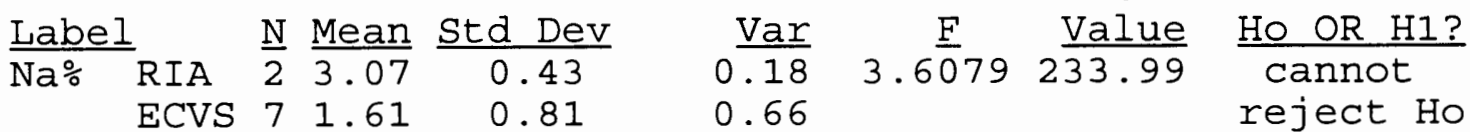
ECVS $71.61 \quad 0.81$

reject Ho

$\mathrm{Cs}$

RIA $21.59 \quad 0.80$

0.65

1.2879

8.81

ECVS 71.59

0.71

0.50

cannot

reject Ho

$\begin{array}{llllll}\mathrm{Ba} & \mathrm{RIA} & 2 & 489 & 62.79 & 3942.72\end{array}$

$2.3506 \quad 233.99$

cannot

ECVS $7 \quad 380 \quad 96.27 \quad 9267.60$

reject $\mathrm{Ho}$

Fe\% RIA 22.41

0.22

0.05

$89.826 \quad 233.99$

cannot

ECVS 75.82

2.12

4.48

reject Ho

SC

RIA 28.5

0.76

0.58

$63.035 \quad 233.99$

cannot

ECVS 717.6

6.04

36.52

reject Ho

Cr RIA $2 \quad 23$

1.19

1.42 ECVS $7 \quad 120$

39.76

1580.94

Co

$\begin{array}{lll}\text { RIA } 2 & 10\end{array}$

0.71

0.51

ECVS 725

9.25

85.65

$167.60 \quad 233.99$

cannot

reject Ho

$\mathrm{Hf}$

RIA 24.13

0.33

0.11

$2.5910 \quad 233.99$

cannot

ECVS 72.47

0.52

0.27

reject Ho

Th

$$
\text { RIA } 24.3
$$

0.71

0.51

3.6211233 .99

cannot ECVS 72.8

1.35

1.83

reject Ho

La RIA 222.3

1.29

1.66

ECVS 711.8

2.85

8.15

4.9101233 .99

cannot reject Ho

Ce RIA 240.2

6.78

45.93

ECVS 722.7

5.69

1.4165

8.81

32.42

cannot reject Ho

Sm RIA 23.96

0.47

0.22

1.0734

8.81

0.20

cannot reject Ho

Eu RIA 21.05

0.020 .0005

$64.262 \quad 233.99$

cannot ECVS 70.99

0.17

0.0295

reject $\mathrm{Ho}$

$\mathrm{Tb} \quad \mathrm{RIA} 20.52$

0.08

0.006

$1.5402 \quad 233.99$

0.010

cannot reject $\mathrm{Ho}$ 


\begin{abstract}
Comparison of Reed Island Ashes (RIA) and

Episodic Cascadian Volcanic Sediments (ECVS)

** T TESTS
\end{abstract}

$\mathrm{Ho}: \mathrm{X} 1=\mathrm{X} 2$

C- $\mathrm{H} 1: \mathrm{X} 1<>\mathrm{X} 2$

$\frac{\text { Label }}{\text { Na\% RIA }} \frac{N}{2} \frac{\text { Mean }}{3.07} \frac{\text { Std Dev }}{0.43} \quad \underline{S p} \quad \underline{\text { Se }} \quad \frac{\text { Value Ho OR H1? }}{+/-}$ ECVS $\begin{array}{lllllll}7 & 1.61 & 0.81 & 0.77 & 0.61 & 2.38 & 2.365 \\ \text { reject Ho }\end{array}$

Cs RIA $21.59 \quad 0.80 \quad+/-\quad$ can't $\begin{array}{llllllll}\text { ECVS } & 7 & 1.59 & 0.71 & 0.72 & 0.58 & -0.0001 & 2.365 \\ \text { reject Ho }\end{array}$

Ba RIA $248962.79 \quad+/-\quad$ can't

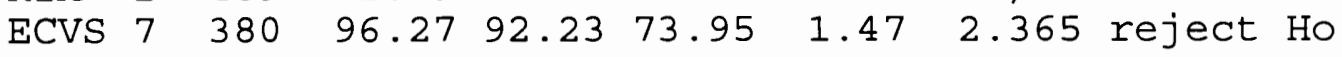

Fe\% RIA $22.41 \quad 0.22 \quad+/-\quad$ can't $\begin{array}{llllllll}\text { ECVS } & 7 & 5.82 & 2.12 & 1.96 & 1.57 & -2.17 & 2.365 \\ \text { reject Ho }\end{array}$

SC RIA $28.5 \quad 0.76 \quad+/$ - can't

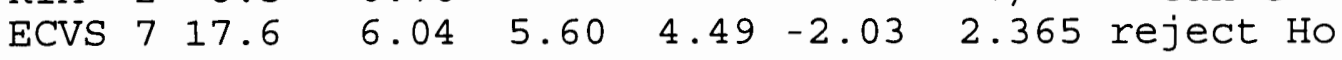

$\begin{array}{lllllll}\text { Cr RIA } & 2 & 23 & 1.19 & +/-\end{array}$ $\begin{array}{llllllll}\text { ECVS } & 7 & 120 & 39.76 & 36.81 & 29.52 & -3.30 & 2.365 \text { reject Ho }\end{array}$

Co RIA $2 \quad 10 \quad 0.71$

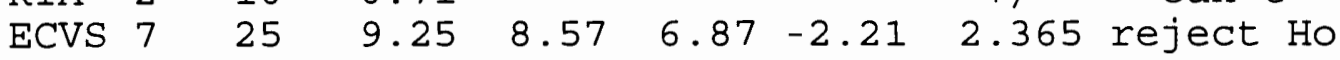

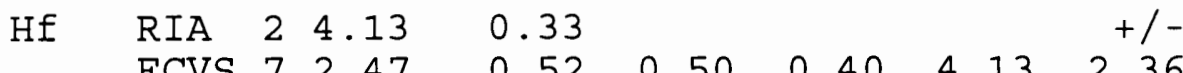

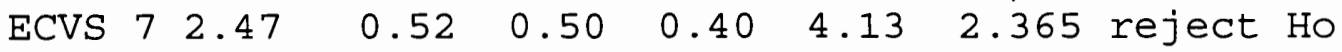

Th RIA $24.3 \quad 0.71 \quad+/-\quad$ can't

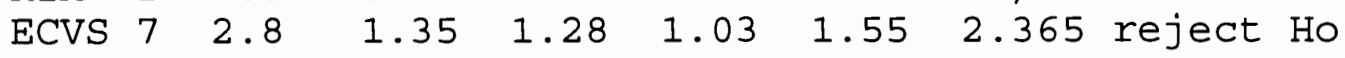

$\begin{array}{lllllllll}\text { La } & \text { RIA } & 2 & 22.3 & 1.29 & & & +/- \\ & \text { ECVS } & 7 & 11.8 & 2.85 & 2.69 & 2.15 & 4.85 & 2.365 \\ & & & \text { reject Ho }\end{array}$

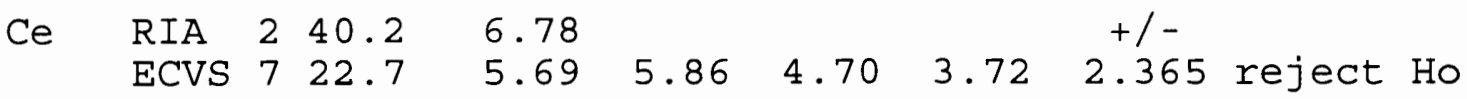

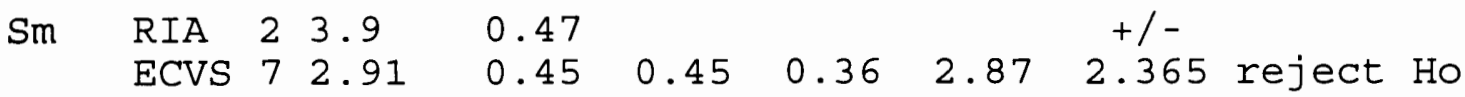

Eu RIA $21.05 \quad 0.02 \quad+/-\quad$ Can't

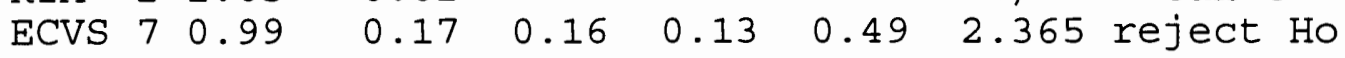

$\begin{array}{lllllllll}\text { Tb RIA } & 2 & 0.52 & 0.08 & & & & +/- & \text { can't } \\ & \text { ECVS } & 7 & 0.53 & 0.10 & 0.10 & 0.08 & -0.13 & 2.365 \\ \text { reject Ho }\end{array}$ 
Comparison of Young Columbia River Sediments (YCRS) and

High-Alumina Basalt Sediments (HABS)

* F TESTS * *

$\mathrm{Ho}: \mathrm{V} 1=\mathrm{V} 2$

$\mathrm{C}-\mathrm{H} 1: \mathrm{V} 1<>\mathrm{V} 2$

\begin{tabular}{|c|c|c|c|c|c|c|c|c|}
\hline Labe & & $\underline{\mathrm{N}}$ & Mean & Std Dev & $\underline{\text { Var }}$ & $\underline{F}$ & Value & Ho OR H1? \\
\hline $\mathrm{Na} \%$ & YCRS & $\overline{8}$ & $\overline{2.51}$ & 0.64 & $0 . \overline{41}$ & $8 . \overline{9} 480$ & $\overline{19.35}$ & cannot \\
\hline & HABS & 3 & 2.42 & 0.21 & 0.05 & & & reject Ho \\
\hline Cs & YCRS & 8 & 1.95 & 0.49 & 0.24 & 1.7057 & 19.35 & cannot \\
\hline & HABS & 3 & 2.03 & 0.37 & 0.14 & & & reject Ho \\
\hline $\mathrm{Ba}$ & YCRS & 8 & 575 & 130.84 & 17119.87 & 15.396 & 19.35 & cannot \\
\hline & HABS & 3 & 598 & 33.35 & 1111.98 & & & reject Ho \\
\hline $\mathrm{Fe} \%$ & YCRS & 8 & 3.17 & 0.51 & 0.26 & 2.2140 & 4.74 & cannot \\
\hline & $\mathrm{HABS}$ & 3 & 5.34 & 0.76 & 0.57 & & & reject Ho \\
\hline Sc & YCRS & 8 & 10.2 & 1.40 & 1.96 & 3.1286 & 19.35 & cannot \\
\hline & HABS & 3 & 18.1 & 0.79 & 0.63 & & & reject Ho \\
\hline $\mathrm{Cr}$ & YCRS & 8 & 40 & 7.63 & 58.17 & 3.9920 & 4.74 & cannot \\
\hline & HABS & 3 & 55 & 15.24 & 232.23 & & & reject Ho \\
\hline Co & YCRS & 8 & 13 & 2.65 & 7.00 & 2.9377 & 4.74 & cannot \\
\hline & HABS & 3 & 23 & 4.53 & 20.55 & & & reject Ho \\
\hline $\mathrm{Hf}$ & YCRS & 8 & 3.48 & 0.46 & 0.22 & 1.1783 & 4.74 & cannot \\
\hline & HABS & 3 & 3.89 & 0.50 & 0.25 & & & reject Ho \\
\hline Th & YCRS & 8 & 4.9 & 1.36 & 1.85 & 4.9286 & 19.35 & cannot \\
\hline & HABS & 3 & 4.5 & 0.61 & 0.37 & & & reject Ho \\
\hline La & YCRS & 8 & 22.0 & 3.49 & 12.21 & 1.0770 & 19.35 & cannot \\
\hline & HABS & 3 & 22.4 & 3.37 & 11.33 & & & reject Ho \\
\hline $\mathrm{Ce}$ & YCRS & 8 & 39.1 & 6.52 & 42.54 & 1.3517 & 4.74 & cannot \\
\hline & HABS & 3 & 44.0 & 7.58 & 57.50 & & & reject Ho \\
\hline $\mathrm{Sm}$ & YCRS & 8 & 3.83 & 0.43 & 0.18 & 2.5310 & 4.74 & cannot \\
\hline & HABS & 3 & 5.01 & 0.68 & 0.47 & & & reject Ho \\
\hline Eu & YCRS & 8 & 1.03 & 0.12 & 0.02 & 3.8567 & 4.74 & cannot \\
\hline & HABS & 3 & 1.50 & 0.24 & 0.06 & & & reject Ho \\
\hline $\mathrm{Tb}$ & YCRS & 8 & 0.54 & 0.07 & 0.0056 & 1.0420 & 4.74 & not \\
\hline & HABS & 3 & 0.76 & 0.08 & 0.0058 & & & ct $\mathrm{HO}$ \\
\hline
\end{tabular}


Comparison of Young Columbia River Sediments (YCRS) and

High-Alumina Basalt Sediments (HABS)

* * T TESTS * *

$\mathrm{HO}: \mathrm{X} 1=\mathrm{X} 2$

C- $\mathrm{H} 1: \mathrm{X} 1<>\mathrm{X} 2$

$\frac{\text { Label }}{\text { Na\% YCRS }} \frac{N}{8} \frac{\text { Mean }}{2.51} \frac{\text { Std Dev }}{0.64} \quad \underline{S p} \quad$ Se $\quad \underline{\text { Value Ho OR H1? }}$

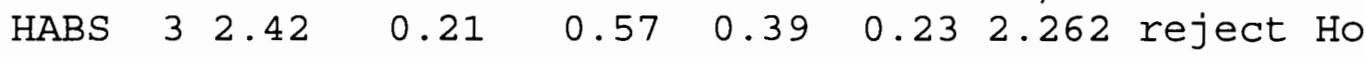

$\begin{array}{lllllllll}\text { Cs } & \text { YCRS } & 8 & 1.95 & 0.49 & & & +/- & \text { can't } \\ \text { HABS } & 3 & 2.03 & 0.37 & 0.47 & 0.32 & -0.27 & 2.262 & \text { reject Ho }\end{array}$

$\mathrm{Ba}$ YCRS $8575130.84 \quad+/-\quad \mathrm{can}^{\prime} \mathrm{t}$

$\begin{array}{lllllllll}\text { HABS } & 3 & 598 & 33.35 & 116.46 & 78.84 & -0.29 & 2.262 & \text { reject Ho }\end{array}$

Fe\% YCRS $8 \quad 3.17 \quad 0.51$

HABS $3 \quad 5.34 \quad 0.76$

$\begin{array}{llll}0.57 & 0.39 & -5.57 & 2.262 \text { reject Ho }\end{array}$

SC YCRS 8 10.2 1.40

$\begin{array}{llll}\text { HABS } & 3 & 18.1 & 0.79\end{array}$

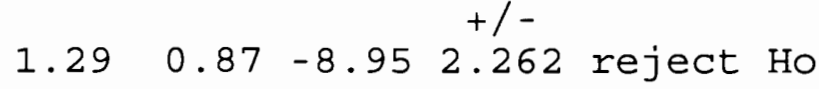

$\begin{array}{lllll}C r & \text { YCRS } & 8 & 40 & 7.63\end{array}$

$\begin{array}{llll}\text { HABS } & 3 & 55 & 15.24\end{array}$

$\begin{array}{llll}9.84 & 6.66 & -2.29 & 2.262 \\ & +/- & \text { reject } \mathrm{Ho}\end{array}$

CO YCRS $8 \quad 13 \quad 2.65$

$\begin{array}{llll}\mathrm{HABS} & 3 & 23 & 4.53\end{array}$

$3.162 .14-4.792 .262$ reject $\mathrm{Ho}$

$\begin{array}{lllll}\text { HE } & \text { YCRS } & 8 & 3.48 & 0.46\end{array}$

$\begin{array}{llll}\text { HABS } & 3 & 3.89 & 0.50\end{array}$

$+1-\quad$ can't

Th YCRS $8 \quad 4.9 \quad 1.36$

HABS $34.5 \quad 0.61$

$\begin{array}{lllll}0.47 & 0.32 & -1.30 & 2.262 & \text { reject } \mathrm{Ho}\end{array}$

$\begin{array}{lllll}1.23 & 0.83 & 0.37 & 2.262 & \text { reject Ho }\end{array}$

La YCRS $822.0 \quad 3.49$

$\begin{array}{llll}\text { HABS } & 3 & 22.4 & 3.37\end{array}$

$\begin{array}{llll}3.47 & 2.35 & -0.19 & 2.262 \\ & \text { reject Ho }\end{array}$

Ce YCRS 8 39.1 6.52

HABS $3 \quad 44.0 \quad 7.58$

$\begin{array}{lllll}6.77 & 4.58 & -1.06 & 2.262 & \text { reject Ho }\end{array}$

$\begin{array}{lllll}\mathrm{Sm} & \text { YCRS } & 8 & 3.83 & 0.43\end{array}$

$\begin{array}{llll}\text { HABS } & 3 & 5.01 & 0.68\end{array}$

$0.50 \quad 0.34 \quad-3.50 \quad 2.262$ reject $\mathrm{Ho}$

$\begin{array}{lllll}E U & \text { YCRS } 8 & 1.03 & 0.12\end{array}$

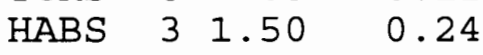

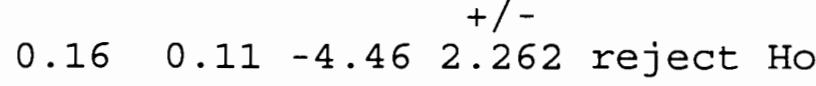

$\begin{array}{lllll}\text { Tb YCRS } 8 & 0.54 & 0.07\end{array}$

$\begin{array}{llll}\text { HABS } & 3 & 0.76 & 0.08\end{array}$

$\begin{array}{lllll}0.07 & 0.05 & -4.36 & 2.262 & \text { reject } \mathrm{Ho}\end{array}$ 
Comparison of Young Columbia River Sediments (YCRS) and

Episodic Cascadian Volcanic Sediments (ECVS)

* F TESTS * *

\begin{tabular}{|c|c|c|c|c|c|c|c|c|}
\hline Label & & $\underline{\mathrm{N}}$ & Mean & Std Dev & Var & $\underline{F}$ & $\begin{array}{c}\mathrm{C}- \\
\text { Value }\end{array}$ & $\begin{array}{r}\mathrm{Ho}: \mathrm{V} 1=\mathrm{V} 2 \\
\mathrm{H} 1: \mathrm{V} 1<>\mathrm{V} 2 \\
\text { Ho OR H1? }\end{array}$ \\
\hline $\mathrm{Na} \%$ & $\begin{array}{l}\text { YCRS } \\
\text { ECVS }\end{array}$ & $\begin{array}{l}\overline{8} \\
7\end{array}$ & $\begin{array}{l}2.51 \\
1.61\end{array}$ & $\begin{array}{l}0.64 \\
0.81\end{array}$ & $\begin{array}{l}0.41 \\
0.66\end{array}$ & 1.5972 & 3.87 & $\begin{array}{l}\text { cannot } \\
\text { reject Ho }\end{array}$ \\
\hline $\mathrm{Cs}$ & $\begin{array}{l}\text { YCRS } \\
\text { ECVS }\end{array}$ & $\begin{array}{l}8 \\
7\end{array}$ & $\begin{array}{l}1.95 \\
1.59\end{array}$ & $\begin{array}{l}0.49 \\
0.71\end{array}$ & $\begin{array}{l}0.24 \\
0.50\end{array}$ & 2.0945 & 3.87 & $\begin{array}{l}\text { cannot } \\
\text { reject Ho }\end{array}$ \\
\hline $\mathrm{Ba}$ & $\begin{array}{l}\text { YCRS } \\
\text { ECVS }\end{array}$ & $\begin{array}{l}8 \\
7\end{array}$ & $\begin{array}{l}575 \\
380\end{array}$ & $\begin{array}{r}130.84 \\
96.27\end{array}$ & $\begin{array}{r}17119.87 \\
9267.60\end{array}$ & 1.8473 & 4.21 & $\begin{array}{l}\text { cannot } \\
\text { reject Ho }\end{array}$ \\
\hline $\mathrm{Fe} \%$ & $\begin{array}{l}\text { YCRS } \\
\text { ECVS }\end{array}$ & $\begin{array}{l}8 \\
7\end{array}$ & $\begin{array}{l}3.17 \\
5.82\end{array}$ & $\begin{array}{l}0.51 \\
2.12\end{array}$ & $\begin{array}{l}0.26 \\
4.48\end{array}$ & 17.288 & 3.87 & reject Ho \\
\hline SC & $\begin{array}{l}\text { YCRS } \\
\text { ECVS }\end{array}$ & $\begin{array}{l}8 \\
7\end{array}$ & $\begin{array}{l}10.2 \\
17.6\end{array}$ & $\begin{array}{l}1.40 \\
6.04\end{array}$ & $\begin{array}{r}1.96 \\
36.52\end{array}$ & 18.595 & 3.87 & reject Ho \\
\hline $\mathrm{Cr}$ & $\begin{array}{l}\text { YCRS } \\
\text { ECVS }\end{array}$ & $\begin{array}{l}8 \\
7\end{array}$ & $\begin{array}{r}40 \\
120\end{array}$ & $\begin{array}{r}7.63 \\
39.76\end{array}$ & $\begin{array}{r}58.17 \\
1580.94\end{array}$ & 27.177 & 3.87 & reject Ho \\
\hline Co & $\begin{array}{l}\text { YCRS } \\
\text { ECVS }\end{array}$ & $\begin{array}{l}8 \\
7\end{array}$ & $\begin{array}{l}13 \\
25\end{array}$ & $\begin{array}{l}2.65 \\
9.25\end{array}$ & $\begin{array}{r}7.00 \\
85.65\end{array}$ & 12.242 & 3.87 & reject Ho \\
\hline $\mathrm{HE}$ & $\begin{array}{l}\text { YCRS } \\
\text { ECVS }\end{array}$ & $\begin{array}{l}8 \\
7\end{array}$ & $\begin{array}{l}3.48 \\
2.47\end{array}$ & $\begin{array}{l}0.46 \\
0.52\end{array}$ & $\begin{array}{l}0.22 \\
0.27\end{array}$ & 1.2676 & 3.87 & $\begin{array}{l}\text { cannot } \\
\text { reject Ho }\end{array}$ \\
\hline Th & $\begin{array}{l}\text { YCRS } \\
\text { ECVS }\end{array}$ & $\begin{array}{l}8 \\
7\end{array}$ & $\begin{array}{l}4.9 \\
2.8\end{array}$ & $\begin{array}{l}1.36 \\
1.35\end{array}$ & $\begin{array}{l}1.85 \\
1.83\end{array}$ & 1.0104 & 4.21 & $\begin{array}{l}\text { cannot } \\
\text { reject Ho }\end{array}$ \\
\hline La & $\begin{array}{l}\text { YCRS } \\
\text { ECVS }\end{array}$ & $\begin{array}{l}8 \\
7\end{array}$ & $\begin{array}{l}22.0 \\
11.8\end{array}$ & $\begin{array}{l}3.49 \\
2.85\end{array}$ & $\begin{array}{r}12.21 \\
8.15\end{array}$ & 1.4983 & 4.21 & $\begin{array}{l}\text { cannot } \\
\text { reject Ho }\end{array}$ \\
\hline $\mathrm{Ce}$ & $\begin{array}{l}\text { YCRS } \\
\text { ECVS }\end{array}$ & $\begin{array}{l}8 \\
7\end{array}$ & $\begin{array}{l}39.1 \\
22.7\end{array}$ & $\begin{array}{l}6.52 \\
5.69\end{array}$ & $\begin{array}{l}42.54 \\
32.42\end{array}$ & 1.3120 & 4.21 & $\begin{array}{l}\text { cannot } \\
\text { reject Ho }\end{array}$ \\
\hline Sm & $\begin{array}{l}\text { YCRS } \\
\text { ECVS }\end{array}$ & $\begin{array}{l}8 \\
7\end{array}$ & $\begin{array}{l}3.83 \\
2.91\end{array}$ & $\begin{array}{l}0.43 \\
0.45\end{array}$ & $\begin{array}{l}0.18 \\
0.20\end{array}$ & 1.1028 & 3.87 & $\begin{array}{l}\text { cannot } \\
\text { reject Ho }\end{array}$ \\
\hline Eu & $\begin{array}{l}\text { YCRS } \\
\text { ECVS }\end{array}$ & $\begin{array}{l}8 \\
7\end{array}$ & $\begin{array}{l}1.03 \\
0.99\end{array}$ & $\begin{array}{l}0.12 \\
0.17\end{array}$ & $\begin{array}{l}0.02 \\
0.03\end{array}$ & 1.9283 & 3.87 & $\begin{array}{l}\text { cannot } \\
\text { reject Ho }\end{array}$ \\
\hline $\mathrm{Tb}$ & $\begin{array}{l}\text { YCRS } \\
\text { ECVS }\end{array}$ & $\begin{array}{l}8 \\
7\end{array}$ & $\begin{array}{l}0.54 \\
0.53\end{array}$ & $\begin{array}{l}0.07 \\
0.10\end{array}$ & $\begin{array}{l}0.006 \\
0.010\end{array}$ & 1.7541 & 3.87 & $\begin{array}{l}\text { cannot } \\
\text { reject Ho }\end{array}$ \\
\hline
\end{tabular}


Comparison of High-Alumina Basalt sediments (HABS) and Episodic Cascadian Volcanic sediments (ECVS)

* F TESTS * *

\begin{tabular}{|c|c|c|c|c|c|c|c|c|}
\hline Labs & & $\underline{\mathrm{N}}$ & Mean & Std Dev & $\underline{\text { Var }}$ & $\underline{F}$ & $\begin{array}{c}\mathrm{C}- \\
\text { Value }\end{array}$ & $\begin{array}{r}\mathrm{HO}: \mathrm{V} 1=\mathrm{V} 2 \\
\mathrm{H} 1: \mathrm{V} 1<>\mathrm{V} 2 \\
\text { Ho OR H1? }\end{array}$ \\
\hline $\mathrm{Na} \%$ & HABS & $\overline{3}$ & $\overline{2.42}$ & 0.21 & $0 . \overline{05}$ & 14.29 & $\overline{19.33}$ & cannot \\
\hline & ECVS & 7 & 1.61 & 0.81 & 0.66 & & & reject Ho \\
\hline $\mathrm{Cs}$ & HABS & 3 & 2.03 & 0.37 & 0.14 & 3.57 & 19.33 & cannot \\
\hline & ECVS & 7 & 1.59 & 0.71 & 0.50 & & & reject Ho \\
\hline $\mathrm{Ba}$ & $\mathrm{HABS}$ & 3 & 598 & 33.35 & 1111.98 & 8.33 & 19.33 & cannot \\
\hline & ECVS & 7 & 380 & 96.27 & 9267.60 & & & reject Ho \\
\hline $\mathrm{Fe} \%$ & HABS & 3 & 5.34 & 0.76 & 0.57 & 7.81 & 19.33 & cannot \\
\hline & ECVS & 7 & 5.82 & 2.12 & 4.48 & & & reject Ho \\
\hline SC & $\mathrm{HABS}$ & 3 & 18.1 & 0.79 & 0.63 & 58.18 & 19.33 & reject Ho \\
\hline & ECVS & 7 & 17.6 & 6.04 & 36.52 & & & \\
\hline $\mathrm{Cr}$ & HABS & 3 & 55 & 15.24 & 232.23 & 6.81 & 19.33 & cannot \\
\hline & ECVS & 7 & 120 & 39.76 & 1580.94 & & & reject Ho \\
\hline Co & HABS & 3 & 23 & 4.53 & 20.55 & 4.17 & 19.33 & cannot \\
\hline & ECVS & 7 & 25 & 9.25 & 85.65 & & & reject Ho \\
\hline $\mathrm{Hf}$ & HABS & 3 & 3.89 & 0.50 & 0.25 & 1.08 & 19.33 & cannot \\
\hline & ECVS & 7 & 2.47 & 0.52 & 0.27 & & & reject Ho \\
\hline Th & HABS & 3 & 4.5 & 0.61 & 0.37 & 4.88 & 19.33 & cannot \\
\hline & ECVS & 7 & 2.8 & 1.35 & 1.83 & & & reject Ho \\
\hline La & HABS & 3 & 22.4 & 3.37 & 11.33 & 1.39 & 5.14 & cannot \\
\hline & ECVS & 7 & 11.8 & 2.85 & 8.15 & & & reject Ho \\
\hline $\mathrm{Ce}$ & HABS & 3 & 44.0 & 7.58 & 57.50 & 1.77 & 5.14 & cannot \\
\hline & ECVS & 7 & 22.7 & 5.69 & 32.42 & & & reject Ho \\
\hline $\mathrm{Sm}$ & HABS & 3 & 5.01 & 0.68 & 0.47 & 2.29 & 5.14 & cannot \\
\hline & ECVS & 7 & 2.91 & 0.45 & 0.20 & & & reject Ho \\
\hline Eu & HABS & 3 & 1.50 & 0.24 & 0.06 & 2.00 & 5.14 & cannot \\
\hline & ECVS & 7 & 0.99 & 0.17 & 0.03 & & & reject Ho \\
\hline $\mathrm{Tb}$ & HABS & 3 & 0.76 & 0.08 & 0.006 & 1.68 & 19.33 & cannot \\
\hline & ECVS & 7 & 0.53 & 0.10 & 0.010 & & & reject Ho \\
\hline
\end{tabular}


Comparison of High-Alumina Basalt Sediments (HABS) and

Episodic Cascadian Volcanic Sediments (ECVS)

** T TESTS

$\mathrm{Ho}: \mathrm{X} 1=\mathrm{X} 2$

$\mathrm{C}-\mathrm{H} 1: \mathrm{X} 1<\mathrm{X} 2$

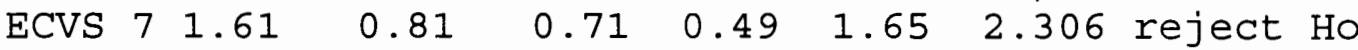

Cs HABS $322.03 \quad 0.37$

ECVS $71.59 \quad 0.71$

$+/-\quad \operatorname{can}^{\prime} t$

2.306 reject Ho

Ba HABS $3 \quad 598 \quad 33.35$

ECVS $7 \quad 380 \quad 96.27$

$85.0258 .67 \quad 3.72 \quad 2.306$ reject Ho

Fe\% HABS $3 \quad 5.34 \quad 0.76$

ECVS $75.82 \quad 2.12$

$\begin{array}{llll}1.87 & 1.29 & -0.38\end{array}$

$+1-\quad$ can't $^{\prime}$

HABS $3 \quad 18.1 \quad 0.79$

6.04

$\begin{array}{lll}5.25 & 3.62 \quad 0.12\end{array}$

$+1-\quad \operatorname{can}^{\prime} t$

ECVS 717.6

6.04

.306 reject Ho

Cr HABS $3 \quad 55 \quad 15.24$

ECVS $7 \quad 120 \quad 39.76$

$35.27 \quad 24.34 \quad-2.66$

$+1-$

2.306 reject Ho

Co HABS $3 \quad 23 \quad 4.53$

ECVS $7 \quad 25 \quad 9.25$

$8.335 .75-0.252 .306$ reject Ho

Hf HABS $3 \quad 3.89 \quad 0.50$

ECVS 72.47

0.52

$0.52 \quad 0.36 \quad 3.97$

$+1-$

2.306 reject Ho

Th HABS $3 \quad 4.5 \quad 0.61$

$\begin{array}{lll}\text { ECVS } 7 & 2.8 & 1.35\end{array}$

$\begin{array}{lll}1.21 & 0.84 & 2.14\end{array}$

$+1-\quad \operatorname{can}^{\prime} t$

2.306 reject Ho

$\begin{array}{lllll}\text { La HABS } & 3 & 22.4 & 3.37\end{array}$

$\begin{array}{lll}\text { ECVS } 7 & 11.8 \quad 2.85\end{array}$

$2.99 \quad 2.06 \quad 5.14$

2.306

Ce HABS $344.0 \quad 7.58$

ECVS $722.7 \quad 5.69$

$6.22 \quad 4.29 \quad 4.96$

$+1-$

2.306 reject $\mathrm{Ho}$

Sm HABS $3 \quad 5.01 \quad 0.68$

$+1-$

ECVS 72.91

0.45

$0.52 \quad 0.36 \quad 5.84$

2.306 reject Ho

$\begin{array}{lllll}\mathrm{Eu} & \mathrm{HABS} & 3 & 1.50 & 0.24\end{array}$

$\begin{array}{lll}\text { ECVS } 7 & 0.99 \quad 0.17\end{array}$

$0.19 \quad 0.13 \quad 3.87$

$+1-$

2.306 reject Ho

$\begin{array}{lllll}\text { Tb HABS } & 3 & 0.76 & 0.08\end{array}$

ECVS 70.53

0.10

$\begin{array}{lll}0.09 & 0.06 \quad 3.47\end{array}$

$+1-$

2.306 reject Ho 